Miron TAFURI QUEIROZ

\title{
A INTEGRAÇÃO DAS CONVENÇÕES DA ORGANIZAÇÃO INTERNACIONAL DO TrABALHO À ORDEM JURÍDICA BrASILEIRA
}

\author{
Dissertação de Mestrado
}

Orientador: Professor Associado Jorge Luiz Souto Maior

Faculdade de Direito da Universidade de São Paulo

São Paulo 


\section{MirOn TAFURI QUEIROZ}

\section{A INTEGRAÇÃO DAS CONVENÇÕES DA ORGANIZAÇÃO INTERNACIONAL DO Trabalho À Ordem JuRídica Brasileira}

Dissertação de Mestrado apresentada ao Programa de Pós-graduação em Direito do Trabalho, do Departamento de Direito do Trabalho e Segurança Social da Faculdade de Direito do Largo São Francisco, da Universidade de São Paulo, para obtenção do título de Mestre em Direito.

Orientador: Professor Associado Jorge Luiz Souto Maior

Faculdade de Direito da Universidade de São Paulo São Paulo 


\section{A INTEGRaÇão das CONVENÇões da ORGANIZAÇÃo INTERNACIONAL DO Trabalho À Ordem JURídica Brasileira}

Dissertação de Mestrado apresentada ao Programa de Pós-graduação em Direito do Trabalho, do Departamento de Direito do Trabalho e Segurança Social da Faculdade de Direito do Largo São Francisco, da Universidade de São Paulo, para obtenção do título de Mestre em Direito.

Orientador: Professor Associado Jorge Luiz Souto Maior

Aprovada em: 
À minha amada esposa, Janaína Luz Camargo, pela força, carinho e paciência.

À minha querida mãe, Claudete Terezinha Tafuri Queiroz, pelo exemplo de luta e pela vida.

Ao meu estimado irmão, Ubiratan Tafuri Queiroz, pela permanente motivação em me tornar um ser humano melhor. 


\section{AGRADECIMENTOS}

Agradeço a todos aqueles que contribuíram para a realização desta dissertação:

Ao meu orientador, Professor Doutor Jorge Luiz Souto Maior, pela competente orientação, bem como, pelo estímulo e compreensão demonstrados em todos os momentos.

Ao Professor Doutor Otávio Pinto e Silva e ao Professor Doutor Carlos Roberto Husek, pelas valiosas críticas e sugestões apresentadas no exame de qualificação, que muito acrescentaram ao trabalho.

Aos colegas que jamais deixaram de acreditar na concretização deste projeto e, especialmente, aos amigos Luis Fabiano de Assis, Olavo de Oliveira Bittencourt Neto e Audaliphal Hildebrando da Silva que, de uma forma mais direta, colaboraram para a sua consecução. 


\section{RESUMO}

Esta dissertação de mestrado tem como proposta tecer uma análise das características gerais das convenções da Organização Internacional do Trabalho e dos principais aspectos relacionados à integração desses instrumentos internacionais ao sistema jurídico brasileiro. Para a consecução desse objetivo, procurou-se, inicialmente, compreender a natureza da própria OIT, abordando-se as condições históricas que concorreram para a sua formação, bem como, suas finalidades, estrutura e formas de atuação. Inferiu-se que mencionado ente enquadra-se no conceito geral de Organização Internacional, possuindo, entretanto, algumas características específicas que o distingue dos demais sujeitos de Direito Internacional Público, dentre as quais avulta como a mais significativa a estrutura tripartite de quase todos os seus órgãos deliberativos. Após a construção dessa base teórica, tornou-se possível a pesquisa sobre os elementos essenciais das convenções internacionais do trabalho. Estudos revelaram que tais diplomas legais são verdadeiros tratados internacionais multilaterais, abertos à ratificação e que têm como escopo primordial a disciplina das relações laborais desenvolvidas no interior dos Estados. Constatou-se, igualmente, que o conteúdo da maioria dessas convenções diz respeito a direitos fundamentais do trabalhador, muito embora não haja um consenso, na doutrina, acerca de quais desses instrumentos podem ser efetivamente considerados como tratados internacionais de direitos humanos. Tendo em vista referida circunstância e também o fato de que existe, em matéria de integração do Direito Internacional ao sistema jurídico pátrio, um tratamento diferenciado para as normas de direitos humanos, realizou-se uma análise sobre os temas mais importantes em matéria de direitos humanos, sendo, ao final, proposto um critério classificatório das convenções, com fundamento no princípio da equivalência. Por derradeiro, foram examinados alguns problemas relacionados à incorporação das convenções da OIT ao ordenamento jurídico pátrio. Concluiu-se que, em se tratando de convenções com conteúdo de direitos humanos, é possível sustentar: a aplicação de um rito especial de incorporação que dispensa o decreto executivo para o início de sua vigência interna; o status de norma materialmente constitucional desses instrumentos; a impossibilidade de denunciá-los.

Palavras-chave: Direito do Trabalho. Direito Internacional. Direitos Humanos. Organização Internacional do Trabalho. Convenções Internacionais do Trabalho 


\begin{abstract}
This master's degree dissertation intends to verify the general characteristics of the International Labor Organization conventions and the main aspects related to the integration of those international instruments into the Brazilian Law. To reach such a goal, initially it was intended an appraisal of ILO's very nature, considering the historical conditions responsible for its creation, as well as of its objectives, structure and ways of action. It was concluded that the character of said institution inserts itself in the general concept of International Organization, although it has some specific characteristics in comparison with other international agencies, among which appears as the most relevant the tripartite structure of almost all of its deliberative organs. After the construction of such theoretical basis, it became possible the research about the essential elements of the international labor conventions. Studies revealed that the conventions are truly multilateral international treaties, open for ratifications and aimed at the regulation of labor relations in national legal systems. Moreover, this paper sustains that most ILO Conventions are related to workers' fundamental rights, although among scholars there is not a consent regarding which of those instruments can effectively be considered international human rights. Considering that circumstance and also the fact that the Brazilian law system disciplines a different treatment for reception of international norms of human rights to Municipal Law, an exam of the most important themes of humans rights was performed, presenting, in the conclusion, a proposition of classification of ILO's Conventions based on the equivalency principle. Finally, it was verified some problems regarding the integration of the international labor conventions to the Brazilian Law. The conclusion reached was that, as far as human rights conventions are concerned, it is possible to sustain: the application of a special procedure for the reception to Municipal Law that does not require an Executive order to turn the norm internally effective; the status of materially constitutional norm of those instruments; the impossibility to denounce them.
\end{abstract}

Key words: Labor Law. International Law. Human Rights. International Labor Organization. International Labor Conventions. 


\section{ÍNDICE}

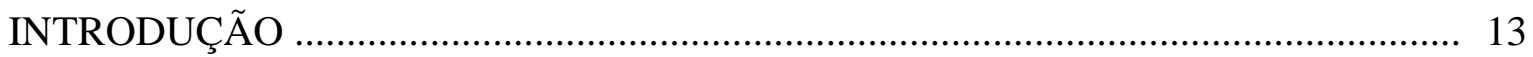

CAPÍTULO I - A ORGANIZAÇÃO INTERNACIONAL DO TRABALHO ............. 18

1. ASPECTOS HISTÓRICOS .................................................................................... 18

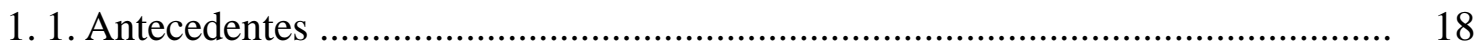

1.2. O Tratado de Versalhes e a Criação da Organização Internacional do

Trabalho

1.3. A Segunda Guerra Mundial e a Vinculação da Organização Internacional do

Trabalho à Organização das Nações Unidas como uma de suas Agências

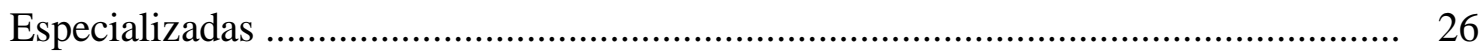

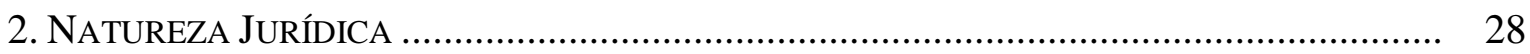

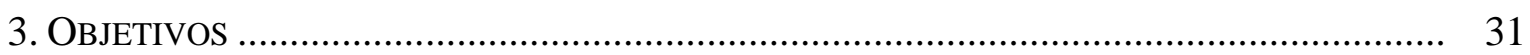

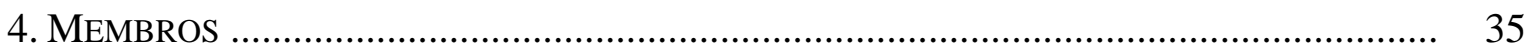

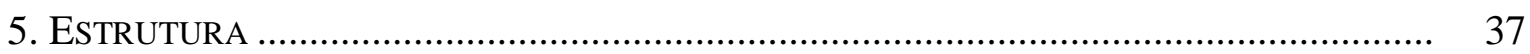

5.1. A Estrutura Tripartite ……………………………………………………... 37

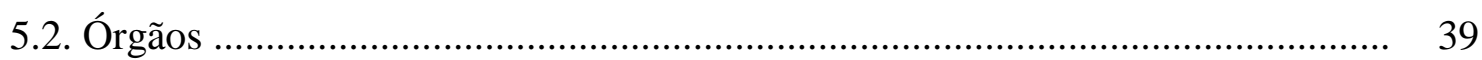

5.2.1. Conferência Internacional do Trabalho ................................................ 39

5.2.2. Conselho de Administração ..................................................................... 41

5.2.3. Repartição Internacional do Trabalho ...................................................... 42

6. ATIVIDADE DESENVOLVIDAS ...........................................................................

6.1. Atividade Normativa ...................................................................................

6.2. Atividade de Cooperação Técnica ……………………………………………... 48

6.3. Atividade de Investigação e Divulgação ............................................................. 49

6.4. Atividade de Controle da Aplicação das Normas Internacionais ........................ 49

CAPÍTULO II - AS CONVENÇÕES INTERNACIONAIS DO TRABALHO ............ 54

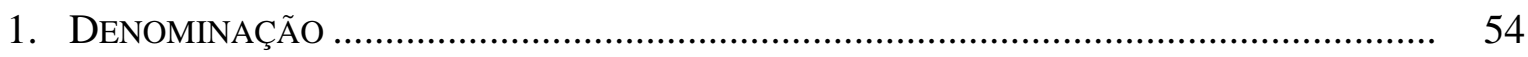


2. CARACTERÍSTICAS GERAIS .............................................................................. 55

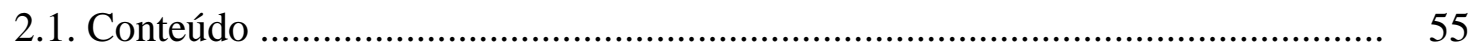

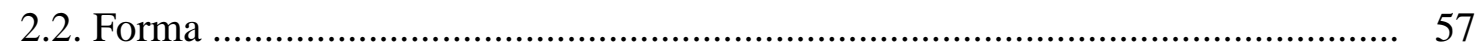

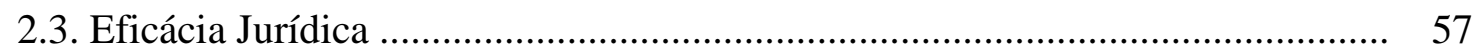

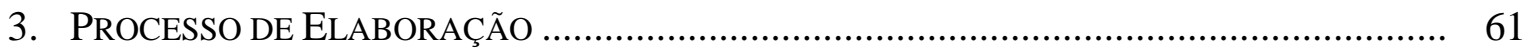

3.1. Inscrição na Ordem do Dia da Conferência …………………………………... 61

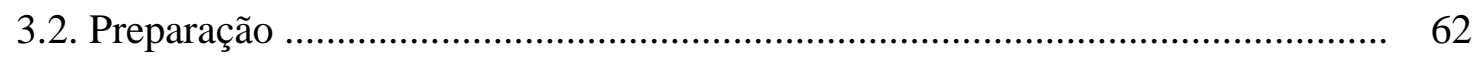

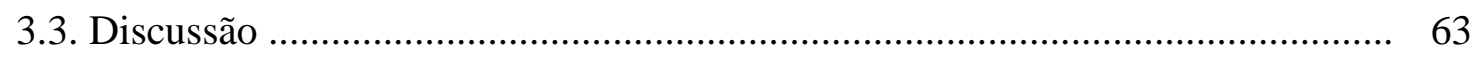

3.4. Aprovação do Projeto de Convenção ................................................................... 64

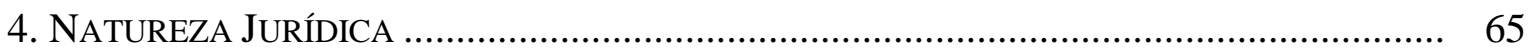

4.1. As Convenções Internacionais do Trabalho como Tratados ................................ 66

4.1.1. Definição e Classificação dos Tratados em Geral ..................................... 66

4.1.2. As Convenções Internacionais do Trabalho como Tratados-leis .............. 68

4.1.3. As Convenções Internacionais do Trabalho como Tratados-contratos ..... 69

4.1.4. Posição Mista …………………………………………………………... 70

4.2. As Convenções Internacionais do Trabalho como Figuras Inéditas no

Direito Internacional ………………………………………………………..... 71

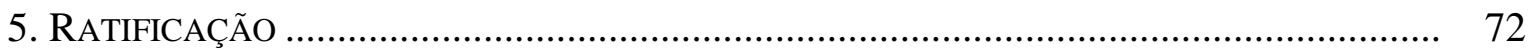

5. 1. Conceito de Ratificação ……………………………………………………....

5.2. Regras de Direito Internacional Aplicáveis à Ratificação das Convenções Internacionais do Trabalho .................................................................................

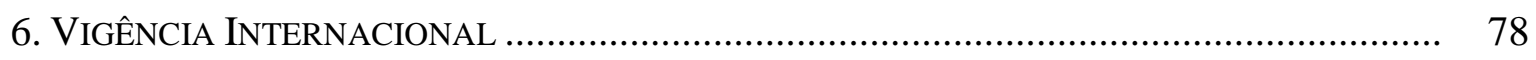

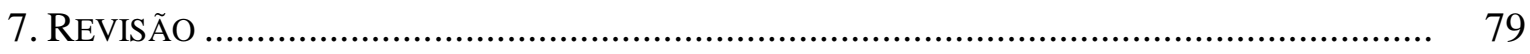

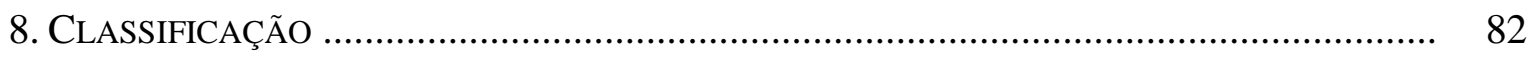

CAPÍTULO III - CONVENÇÕES INTERNACIONAIS DO TRABALHO

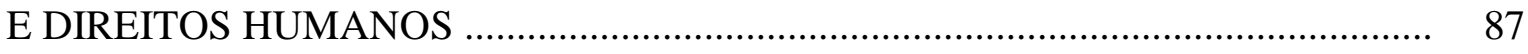

1. TEORIA GERAL DOS DiREITOS HUMANOS ............................................................... 87 
1.3.1. A Antiguidade

1.3.2. A Limitação do Poder Político

1.3.3. A Afirmação dos Direitos e Liberdades Individuais

a ) A Independência dos Estados Unidos e as Declarações de Direitos

Norte-americanas

b) A Revolução Francesa e a Declaração dos Direitos do Homem e do Cidadão de 1789

1.3.4. A Afirmação dos Direitos Humanos de Caráter Econômico e

Social

a) A Constituição Mexicana de 1917

b) A Constituição de Weimar de 1919

c) O Tratado de Versalhes de 1919

1.3.5. A Internacionalização dos Direitos Humanos

a) A Carta das Nações Unidas de 1945

b) A Declaração Universal dos Direitos do Homem de 1948

1.4. A Teoria Geracional dos Direitos Humanos e Suas Críticas

1.5. Princípios dos Direitos Humanos

1.5.1. Os Princípios Axiológicos dos Direitos Humanos

a) A Dignidade da Pessoa Humana

b) A Liberdade

c) A Igualdade

d) A Solidariedade

1.5.2. Os Princípios Estruturais do Sistema dos Direitos Humanos

a) O Princípio da Complementariedade Solidária

b) O Princípio da Irreversibilidade

c) O Princípio da Aplicabilidade Imediata e da Plena Eficácia das Normas Definidoras 
2. AS CONVENÇÕES DA ORGANIZAÇÃO INTERNACIONAL DO TRABALHO SOBRE

DiREITOS HUMANOS

2.1. O Problema da Identificação dos Tratados Internacionais de Direitos

Humanos: Perspectivas de Abordagem

2.2. A Identificação das Convenções Internacionais do Trabalho sobre Direitos

Humanos

2.2.1. Análise Crítica ao Critério Adotado pela Organização Internacional do Trabalho na Declaração de 1998

2.2.2. Construção de um Critério Adequado para a Identificação das

Convenções Internacionais do Trabalho sobre Direitos Humanos

2.2.3. Classificação das Convenções da Organização Internacional do

Trabalho Segundo o Critério Estabelecido

\section{CAPÍTULO IV - AS CONVENÇÕES INTERNACIONAIS DO TRABALHO NA}

ORDEM JURÍDICA NACIONAL

1. As RELAÇÕES ENTRE o DiREITO INTERNACIONAL E O DiREITO INTERNO

1.1. Teoria Dualista

1.2. Teoria Monista

1.2.1. O Monismo Nacionalista

1.2.2. O Monismo Internacionalista

1.3. Posição Adotada pelo Brasil

2. A INCORPORAÇÃO DAS CONVENÇÕES INTERNACIONAIS DO TRABALHO À ORDEM

JURÍDICA BRASILEIRA

2.1. Considerações Preliminares

2.2. O Procedimento Geral para a Incorporação dos Tratados Internacionais ao

Direito Brasileiro 
2.3. Especificidades Relacionadas à Incorporação dos Tratados Internacionais de Direitos Humanos

2.3.1. As Teses sobre a Incorporação Automática

2.3.2. A Problemática Suscitada pela Emenda Constitucional n. 45/04

2.4. A Incorporação das Convenções Internacionais do Trabalho ao Direito

Brasileiro

2.5. O Jus Cogens e a Declaração da Organização Internacional do Trabalho sobre os Princípios e Direitos Fundamentais no Trabalho: Desnecessidade de Ratificação das Convenções?

3. A HiERARQuia das CONVENÇÕES INTERNACIONAIS DO TRABALHO NO

SISTEMA JURÍDICO BRASILEIRO

3. 1. A Hierarquia dos Tratados em Geral

3. 2. A Hierarquia dos Tratados de Direitos Humanos

3.2.1 A Visão da Moderna Doutrina Constitucionalista e a Mudança de

Posição adotada pelo Supremo Tribunal Federal 176

3.2.2. As Conseqüências da Emenda Constitucional n. 45/04 no Tocante à

Hierarquia dos Tratados de Direitos Humanos 180

3.3. A Hierarquia das Convenções Internacionais do Trabalho 188

4. A DENÚNCIA DAS CONVENÇÕES INTERNACIONAIS DO TRABALHO

4.1. Princípios e Condições Aplicáveis à Denúncia dos Tratados em Geral

4.2. Procedimento de Denúncia das Convenções da Organização Internacional do

Trabalho

4.3. A Controvérsia Acerca da Impossibilidade de Denúncia das Convenções

Internacionais do Trabalho sobre Direitos Humanos

CONSIDERAÇÕES FINAIS

BIBLIOGRAFIA 209 


\section{INTRODUÇÃO}

A proposta da presente dissertação de mestrado é analisar as principais características das convenções internacionais do trabalho, de modo a possibilitar o estudo da integração desses diplomas à ordem jurídica nacional.

Cumpre advertir, desde já, que não constitui objeto deste trabalho tecer um exame pormenorizado do conteúdo de cada uma das referidas convenções, mas apenas realizar um estudo global de seus elementos caracterizadores, de maneira a permitir a apreensão da natureza jurídica desses instrumentos e, assim, fornecer um arcabouço teórico mínimo para uma posterior pesquisa acerca dos aspectos mais pertinentes à questão da sua integração na ordem jurídica pátria.

Referida pesquisa, que também compõe um dos intentos desta dissertação, ater-se-á, por sua vez, somente aos problemas mais sensíveis relacionados ao tema da interação e harmonização desses instrumentos convencionais ao universo jurídico brasileiro. Serão analisados, portanto, o próprio procedimento formal de incorporação desses tratados, a questão da estatura hierárquica que devem ocupar dentro do sistema normativo nacional e, finalmente, a via ordinária pela qual podem deixar de pertencer à ordem jurídica, ou seja, a denúncia. Por uma opção metodológica, não terão lugar neste exame questões relativas à aplicação das convenções internacionais do trabalho, tais como, a problemática da interpretação de suas disposições, a sua executoriedade ou o controle de aplicação realizado pela Organização Internacional do Trabalho. Todavia, em determinados momentos, poder-se-á, obliquamente, tecer comentários sobre algum ou alguns desses aspectos para facilitar o desenvolvimento e a compreensão de determinado assunto, não havendo, contudo, a pretensão de esgotá-los ou aprofundá-los.

Uma vez delimitado o objeto da presente dissertação, cumpre, a partir de agora, apresentá-lo sucintamente, assim como, desvelar as razões que o colocam como um assunto de alto interesse acadêmico e prático.

As convenções internacionais do trabalho são os principais instrumentos da regulamentação internacional do trabalho. Produtos da atividade normativa de uma Organização Internacional criada com o escopo de assegurar bases sólidas para a paz universal, por meio da melhoria das condições sociais do ser humano, cuidam-se de verdadeiros tratados internacionais multilaterais, abertos à ratificação e que têm como objeto primordial a disciplina das relações laborais desenvolvidas no interior dos Estados. 
Constituem-se, pois, como fontes formais de direito, podendo integrar o sistema jurídico dos países que a elas adiram como norma positiva, capaz de gerar direitos subjetivos e obrigações correspondentes. Além disso, podem elas determinar a assunção de responsabilidades no plano internacional por parte do Estado que as ratifica, na medida em que o coloca frente a um controle de aplicação de suas disposições, realizado pela própria Organização Internacional do Trabalho.

Em razão de apresentarem as citadas características, é possível asseverar que tais instrumentos, desde seu surgimento nas primeiras décadas do século XX, inovaram o panorama então existente no Direito Internacional Público, que basicamente compunha-se por normas bilaterais e reguladoras apenas das relações entre Estados, no âmbito estritamente governamental. De fato, as convenções internacionais do trabalho romperam com a lógica imperante nos primórdios do Direito Internacional de arranjos e concessões recíprocas entre países, fazendo com que esse ramo jurídico também passasse a voltar seu foco à salvaguarda de direitos do ser humano. Tal circunstância, por si só, seria suficiente para demonstrar a relevância para a Ciência Jurídica do estudo das convenções internacionais do trabalho. Todavia, a importância desses instrumentos internacionais transcende esse fator.

A própria consolidação do Direito do Trabalho como ramo jurídico autônomo está diretamente ligada à demanda por uma regulamentação internacional do trabalho. A busca por mecanismos que permitiriam o alcance da justiça social, a humanização das relações de trabalho e, ao mesmo tempo, impediriam, em um mundo capitalista, que a consecução desses objetivos pelos Estados não fosse frustrada pela concorrência internacional conduziu à criação da Organização Internacional do Trabalho em 1919. Nessa oportunidade foram enunciados os princípios que emanciparam o segmento juslaboral, tornando-se mencionado ente internacional uma das primordiais fontes irradiadoras de normas jurídicas destinadas a universalizar tais princípios.

As convenções internacionais do trabalho estão, portanto, na base da própria formação e desenvolvimento do Direito do Trabalho, sendo totalmente pertinente a ilação de que sua análise é de capital interesse também para uma perfeita compreensão de diversos aspectos peculiares a esse segmento.

Não bastasse isso, a produção normativa da Organização Internacional do Trabalho, materializada, sobretudo, por suas convenções foi reconhecidamente um dos alicerces do processo de internacionalização dos direitos humanos. Muito embora exista 
uma tendência da doutrina internacionalista em afirmar que a consolidação do chamado Direito Internacional dos Direitos Humanos tenha ocorrido no período posterior à Segunda Guerra Mundial, não há objeções acerca do papel precursor desempenhado pela Organização Internacional do Trabalho, por meio de suas convenções, para o alcance de tal estágio de proteção dos direitos do homem. Logo, o exame das referidas normas internacionais assume relevância igualmente para o entendimento adequado do sistema de proteção de direitos humanos construído no decorrer da História.

No que concerne à questão da integração das convenções internacionais do trabalho ao ordenamento jurídico brasileiro, o tema avulta como um dos mais atuais e controvertidos na doutrina e jurisprudência nacionais.

Principalmente após a promulgação da Constituição de 1988, passou a ganhar corpo, na esfera doutrinária, a tese de que a ordem jurídica pátria haveria consagrado um sistema misto de recepção dos tratados internacionais. Tal entendimento encontraria fulcro nos $\S \S 1^{\circ}$ e $2^{\circ}$ do art. $5^{\circ}$ da Constituição Federal. O primeiro desses dispositivos torna expresso o princípio da aplicabilidade imediata dos direitos fundamentais, o que permitiria sustentar a tese de que os tratados internacionais sobre direitos humanos poderiam ser incorporados por meio de um procedimento facilitado em relação aos demais tratados. O segundo dispositivo dá azo à abertura material da Constituição da República à recepção de outros direitos fundamentais, não constantes de seu rol formal, mas sediados em tratados internacionais. Com esteio nele, foi possível construir o entendimento doutrinal de que os instrumentos convencionais sobre direitos humanos teriam a mesma envergadura das normas constitucionais que estabelecem direitos fundamentais, ao passo que os demais diplomas internacionais não gozariam desse grau na hierarquia das normas. Esse último juízo, por sua vez, alimentou a doutrina também a tecer considerações sobre a impossibilidade de denúncia dos instrumentos internacionais de direitos humanos, com base no disposto no art. 60, $\S 4^{\circ}$, da Constituição Federal.

As teses encimadas sempre foram, contudo, alvo de acalorados debates, não encontrando, muitas vezes, eco na órbita jurisprudencial. A instabilidade que esta situação causava levou o legislador constituinte derivado a realizar uma reforma constitucional tendente a resolver os dissensos existentes. Ocorreu, assim, a introdução de um $\S 3^{\circ}$ ao art. $5^{\circ}$ da Constituição Federal, cuja redação, porém, longe de pacificar as opiniões, tem suscitado novas controvérsias. 
As questões supracitadas atingem em cheio a problemática da recepção das convenções internacionais do trabalho, posto que muitas dessas normas podem ser classificadas como tratados de direitos humanos. O estudo desse tema, de maneira minuciosa, mostra-se, assim, como uma contribuição valiosa à Ciência do Direito. Ainda que as conclusões alcançadas revelem-se, como em quase todas as searas jurídicas, sujeitas a críticas, o simples fato de estimular o debate acadêmico sobre o assunto faz com que os fins dessa dissertação se justifiquem plenamente.

Demonstrada a relevância do tema, cabe, neste momento, expor o plano de desenvolvimento desta dissertação.

O presente trabalho possui, além deste tópico introdutório, quatro capítulos principais e um tópico referente às considerações finais.

O primeiro dos capítulos principais traz um panorama da Organização Internacional do Trabalho, entidade responsável pela criação das convenções internacionais do trabalho. Nessa seção são expostos, além de alguns aspectos históricos que determinaram o surgimento da mencionada Organização, também alguns elementos que a caracterizam, tais como, seus objetivos, membros, estrutura e atividades desenvolvidas. Tal capítulo foi inserido nesta dissertação com a finalidade de fornecer uma base para uma perfeita apreensão da natureza jurídica das convenções internacionais, bem como, de suas principais características.

O capítulo segundo parte para a análise propriamente dita das convenções internacionais do trabalho. Nele são estudadas suas características e natureza jurídica, assim como, aspectos relacionados à sua ratificação, vigência, revisão e, finalmente, classificação. Quanto a esse último ponto, entretanto, optou-se por apresentar as principais classificações existentes na doutrina tradicional, advertindo-se, contudo, sobre a sua pouca utilidade para o alcance dos fins colimados nesta dissertação e sobre a necessidade de um novo critério classificatório, que por sua vez constituiu um dos objetos do capítulo subseqüente.

O capítulo terceiro foi pensado tendo em vista a questão da duplicidade de regimes aplicáveis na ordem jurídica nacional à recepção dos tratados internacionais. Considerando que a Constituição Federal estabelece regras distintas aos tratados internacionais de direitos humanos daquelas aplicáveis aos demais tratados, torna-se primordial que se analise algumas questões relativas ao sistema de proteção dos direitos humanos, antes de adentrar propriamente na temática da integração das convenções 
internacionais do trabalho à ordem jurídica brasileira. Em tal segmento, são vistos alguns elementos imprescindíveis à compreensão da dinâmica dos direitos humanos, procurandose, em seguida, estabelecer um critério objetivo que permita a classificação de todas as convenções internacionais do trabalho atualmente vigentes como sendo ou não tratados internacionais de direitos humanos.

O capítulo quarto cuida especificamente da problemática atinente à integração das convenções internacionais do trabalho ao sistema jurídico brasileiro. Nele são expostas as teorias que procuram explicar como se dão as relações entre Direito Interno e Direito Internacional, assim como, são analisadas todas as questões polêmicas relativas ao procedimento de incorporação, hierarquia e denúncia dos tratados internacionais e que, conseqüentemente, podem ser justapostas às convenções internacionais do trabalho.

Finalmente, no tópico relativo às considerações finais são apresentadas as principais conclusões obtidas com o desenvolvimento desta pesquisa. 


\section{CAPÍTULO I - A ORGANIZAÇÃO INTERNACIONAL DO TRABALHO}

\section{Aspectos Históricos}

\subsection{Antecedentes}

A concepção de uma regulamentação das relações de trabalho no plano internacional remonta à primeira metade do século XIX, quando, sobretudo, na Europa passou-se a conhecer os efeitos negativos das profundas transformações sociais desencadeadas com a Revolução Industrial e com a Revolução Francesa.

A Revolução Industrial, que despontou na Inglaterra, durante as últimas décadas do século XVIII, alastrando-se pelo continente europeu no decorrer do século XIX, ${ }^{1}$ trouxe como um de seus subprodutos sociais a submissão do operariado a condições desumanas de vida e trabalho. Tal conseqüência, como bem evidencia ARNALDO SÜSSEKIND, teve como esteio a aplicação às relações de trabalho dos postulados da igualdade formal (igualdade perante a lei), liberdade contratual e não intervenção do Estado na esfera particular, advindos da filosofia liberal-individualista consagrados com a Revolução Francesa de $1789 .{ }^{2}$ De fato, sob a ótica do Estado Liberal, os detentores dos meios de produção e os trabalhadores eram vistos como contratantes iguais em direitos, desprezando-se o enorme abismo econômico existente entre ambos, o que permitiu que os primeiros impusessem condições de trabalho extremamente degradantes aos últimos.

Esse quadro de penúria da classe operária fez com que esta se organizasse e desencadeasse um processo reivindicatório pela melhoria de sua condição social, o que disseminou em vários países a idéia da necessidade da intervenção estatal nas relações laborais, com o escopo de se criar uma legislação protetiva. É inegável, portanto, que a tese da regulamentação das relações de trabalho encontrou uma forte inspiração humanitária. Todavia, o que parece ter sido decisivo para que essa proteção ganhasse uma dimensão internacional foi a preocupação dos industriais e dos governos com a concorrência econômica, em razão dos impactos nos custos de produção que a adoção unilateral de medidas tutelares poderia acarretar. Revelou-se, assim, imprescindível que houvesse uma

\footnotetext{
${ }^{1}$ ERIC J. HoBSBAWM, A Era das Revoluções - Europa 1789-1848, trad. port. de Maria Tereza Lopes Teixeira e Marcos Penchel,, 21ª ed., São Paulo, Paz e Terra, 2007, p. p. 50-52 e FrANCISCO IGLÉSIAS, História Geral e do Brasil, São Paulo, Ática, 1989, p.p. 101-102.

${ }^{2}$ Direito Internacional do Trabalho, $3^{\mathrm{a}}$ ed., São Paulo, Saraiva, 2000, p. p. 81-83.
} 
internacionalização da legislação social trabalhista, pela qual fossem garantidos direitos mínimos aos trabalhadores, de maneira relativamente uniforme e simultânea, por diversos Estados. ${ }^{3}$

Parte da doutrina credita ao industrial bretão Robert Owen a primazia da idealização de uma ação internacional no plano das relações de trabalho. ${ }^{4}$ Segundo ARNALDO SÜSSEKIND, a proposta por ele endereçada ao Congresso Aix-la-Chapelle, em 1818, convidando os governos europeus a adotarem, de maneira idêntica, uma limitação legal da jornada de trabalho, correspondeu à primeira manifestação que denota a preocupação em associar as idéias da instituição de direitos irrenunciáveis aos trabalhadores e da necessidade de se equilibrar os ônus da proteção social entre países industrializados e concorrentes no comércio internacional. ${ }^{5}$

As idéias de Robert Owen foram, mais tarde, incorporadas e aprofundadas pelo economista francês Jérôme-Adolphe Blanqui que, em 1838, propôs, em sua obra Cours d'Économie Industrialle, a tese da celebração de tratados internacionais para melhoria das condições sociais dos trabalhadores. Entretanto, foi o industrial francês Daniel Legrand quem, de maneira mais contínua, contribuiu para esse processo, endereçando cartas aos governos da França, Inglaterra, Suíça e Prússia, por meio das quais aconselhava-os sobre a imprescindibilidade da adoção de uma lei internacional que regesse as relações de trabalho como forma viável de se garantir a paz e a ordem social, sem prejuízo da concorrência das indústrias no mercado mundial. Embora não tenham surtido o efeito desejado por Legrand, suas cartas, depois de publicadas em 1853, geraram grande repercussão na Europa, influenciando decisivamente a regulamentação internacional das relações de trabalho. ${ }^{6}$

Além dos mencionados precursores, a doutrina arrola ainda as importantes contribuições do inglês Charles Hindley, do belga Edouard Ducpétiaux e do francês Louis

\footnotetext{
${ }^{3}$ GERALdo W. VON POTOBSKY e HÉCTOR G. BARTOLOMEI DE LA CRUZ, La Organización Internacional del Trabajo - El Sistema Normativo Internacional - Los Instrumentos sobre Derechos Humanos Fundamentales, Buenos Aires, Editorial Astrea de Alfredo y Ricardo Depalma, 1990, p. 3.

${ }^{4}$ Nesse sentido, confira-se ARNALDO SÜSSEKIND, op. cit. (Direito Internacional...), p. 83-85 e GERALDO W. VON POTOBSKY e HÉCTOR G. BARTOLOMEI DE LA CRUZ, op. cit., p. 4.

${ }^{5}$ Op. cit., p. 85.

${ }^{6}$ ARNALDO SÜSSEKIND, op. cit. (Direito Internacional...), p. p. 85-86 e WALKÜRE LOPES RIBEIRO DA SILVA, O.I.T. e Direito do Trabalho no Brasil, dissertação (mestrado), Faculdade de Direito da Universidade de São Paulo, São Paulo, 1982, p. p. 51-52.
} 
René Villarmé para a formação da tese da regulamentação internacional do trabalho, todas ocorridas na primeira metade do século $\mathrm{XIX}^{7}$.

A partir da difusão de tais idéias, foram organizados os primeiros movimentos em favor da elaboração de uma legislação internacional. Em 1856, na cidade de Bruxelas, foi proposto pelo alemão Hahn, no Congresso Internacional de Beneficência, a aprovação de medidas tuitivas do trabalho no plano internacional. Iniciativa que ganhou reforço no mesmo congresso realizado um ano depois, em Frankfurt, quando se aprovou uma moção nesse mesmo sentido. ${ }^{8}$

Em 1864, a Assembléia Internacional dos Trabalhadores, mais conhecida como Primeira Internacional, afastando-se ligeiramente da ideologia marxista, defendeu a idéia de uma legislação social supranacional, reivindicando, dois anos mais tarde, no Congresso de Genebra, a limitação internacional da jornada de trabalho. ${ }^{9}$

Registrem-se, ainda, como importantes movimentos organizados, o Congresso Internacional Operário, realizado na cidade francesa de Roubaix em 1884 e o Congresso Socialista de Paris, de 1889. ${ }^{10}$

O amplo debate sobre as idéias relativas à regulamentação internacional do trabalho despertou também a atenção dos Estados para o problema. Reputa-se à Suíça a primeira ação oficial acerca da questão, ao requerer, já no ano de 1855 , a realização de uma reunião para tratar da questão operária junto aos principais países da Europa, sem, contudo, obter sucesso. Quase três décadas mais tarde, a Suíça novamente iniciou, em 1881, uma campanha diplomática para o estabelecimento de uma legislação protetora em nível internacional, sem melhores resultados. ${ }^{11}$

Finalmente, em 1889, a Suíça envidou novos esforços diplomáticos, convidando formalmente os países industrializados europeus para uma conferência que se realizaria na cidade de Berna em 1890. Porém, o Kaiser alemão Guilherme II tomou para si a iniciativa dos suíços e a conferência que deveria ser em Berna ocorreu em Berlim, no dia 15 de março do mesmo ano.

\footnotetext{
${ }^{7}$ Nesse sentido, confira-se GerAldo W. vON POTOBSKY e HÉCTOR G. BARTOLOMEI DE LA CRUZ, op. cit., p. 4 ,

${ }^{8}$ ARNALDO SÜSSEKIND, op. cit. (Direito Internacional...), p. 86.

9 ARNALDO SÜSSEKIND, op. cit. (Direito Internacional...), p. 87. Em sentido contrário, WAGNER D. GIGLIO argumenta que seria mais correto afirmar que a Primeira Internacional, idealizada por Karl Marx e Friedrich Engels não defendia propriamente a idéia de uma legislação protecionista supranacional, mas a uniformização das reivindicações trabalhistas em todos os países. In O.I.T. e Convenções Internacionais do Trabalho Ratificadas pelo Brasil, São Paulo, Sugestões Literárias, 1973, p. p. 21-22.

${ }^{10}$ ARNALDO SÜSSEKIND, op. cit. (Direito Internacional...), p. p. 87-88.

${ }^{11}$ Geraldo W. von Potobsky e HÉCtOR G. BARTOlOMEI DE la CRUZ, op. cit., p. 4.
} 
A Conferência de Berlim contou com a participação de treze países: Alemanha, Áustria-Hungria, Bélgica, Dinamarca, França, Holanda, Inglaterra, Itália, Luxemburgo, Noruega, Portugal, Suécia e Suíça. A ordem do dia abordou os seguintes temas: trabalho nas minas; descanso aos domingos; trabalho das crianças; trabalho das mulheres; trabalho dos jovens; execução e vigilância das resoluções adotadas. ${ }^{12}$

Malgrado os importantes temas debatidos, a Conferência de Berlim não atingiu os objetivos a que se propunha. De fato, como bem observa WALKÜRE LOPES RIBEIRO DA SILVA, com base nas lições de Georges Scelle e Ernest Mahain, não houve na citada conferência a concretização de medidas efetivas que beneficiassem os trabalhadores, sendo a maioria dos votos iniciados pela fórmula "é desejável que ...". Esse aparente fracasso pode ser atribuído à preocupação dos países em preservar sua soberania, não admitindo a adoção de medidas que importassem compromissos internacionais. ${ }^{13}$ No entanto, não há como contestar que a iniciativa proporcionou o acúmulo de significativo material para a elaboração da legislação internacional que iria se realizar em um período subseqüente, sendo, nesse sentido, um relevante marco histórico.

Em 1897 ocorreu, em Bruxelas, o primeiro Congresso Internacional de Legislação do Trabalho, no qual foi constituída uma comissão composta por Victor Brantes, Ernest Manhaim e o Duque de Ursel, com o escopo de preparar a criação de uma associação internacional para elaboração de uma legislação do trabalho de alcance supranacional. No ano de 1900, durante o segundo Congresso Internacional de Legislação do Trabalho, sediado em Paris, referida comissão apresentou o resultado de seus trabalhos, sendo aprovada a criação da Associação Internacional para Proteção Legal dos Trabalhadores. $^{14}$

A Associação Internacional para Proteção Legal dos Trabalhadores era uma entidade de caráter privado, mas subvencionada pelo governo suíço. Sua sede foi inaugurada no dia $1^{\circ}$ de maio de 1900, na Basiléia (Suíça). De acordo com seus estatutos, competia à citada associação dentre outras coisas: servir como mecanismo de união entre as pessoas que, nos diversos países industriais, consideravam necessária a criação de uma legislação protetora dos trabalhadores; favorecer o estudo dos seus membros sobre a legislação do trabalho de diversos países e sua respectiva aplicação; realizar congressos

\footnotetext{
${ }^{12}$ ARNALDO SÜSSEKIND, op. cit. (Direito Internacional...), p. p. 89-90.

${ }^{13}$ Op. cit., p. p. $58-59$.

${ }^{14}$ ARNALDO SÜSSEKIND, op. cit.(Direito Internacional...), p. p. 91-92.
} 
internacionais sobre o tema; organizar um escritório internacional do trabalho para a publicação nos idiomas inglês, francês e alemão da legislação do trabalho de vários países.

Dentre as inúmeras contribuições para o futuro da proteção internacional dos trabalhadores, merecem destaque duas práticas da Associação Internacional para Proteção Legal dos Trabalhadores: a criação de um órgão permanente encarregado de realizar estudos e centralizar as informações relativas à legislação trabalhista de vários países (o Escritório Internacional do Trabalho); o método de trabalho aplicado, que adotava a realização de duas conferências para a aprovação de convenções - uma conferência técnica para deliberação de resoluções fundamentadas em estudos previamente realizados pelo Escritório Internacional do Trabalho e, posteriormente, uma conferência diplomática para decisão em definitivo sobre tais questões.

Conforme expõem Nicolas VAlticos, a despeito de seu caráter privado, a Associação prefigurou o que viria a ser a Organização Internacional do Trabalho, sobretudo, por revelar a necessidade de um trabalho sólido antes da convocação de uma conferência internacional. ${ }^{15}$

A experiência bem sucedida da metodologia utilizada pela Associação Internacional para Proteção Legal dos Trabalhadores pode ser verificada pelas Conferências de Berna de 1905 e 1906, ambas convocadas pelo governo suíço, por solicitação da referida Associação. A primeira, de caráter técnico, contou com especialistas oficialmente designados pelos governos de 15 países, resultando na aprovação de resoluções sobre a proibição do trabalho da mulher na indústria e restrição da utilização de fósforo branco. A segunda, em escala diplomática, culminou com a aprovação de ambos os pontos, dando ensejo à criação de duas convenções internacionais que tratavam justamente das mencionadas questões. As convenções internacionais aprovadas em Berna foram ratificadas pela maior parte dos Estados que compuseram a conferência, sendo as ratificações depositadas junto ao Conselho Federal da Suíça. Concebeu-se, igualmente, nas referidas convenções, um sistema de relatórios sobre a aplicação de seu conteúdo, que cada Estado deveria periodicamente apresentar. Surgiam, assim, as primeiras convenções internacionais sobre as relações de trabalho, já com características muito próximas às convenções que seriam posteriormente criadas no seio da Organização Internacional do Trabalho.

\footnotetext{
${ }^{15}$ Derecho Internacional del Trabajo, trad. esp. de Maria Jose Triviño, Madrid, Editorial Tecnos, 1977, p. p. 46-47.
} 
Houve, porém, um lapso de oito anos para que um novo ciclo de criação de convenções internacionais fosse desencadeado sob o influxo da Associação. Mais uma vez, por iniciativa do governo Suíço, realizou-se, em 1913, na cidade de Berna, a conferência técnica que preparou dois novos projetos de convenção: um relativo à proibição do trabalho do menor na indústria e outro referente à limitação da jornada de trabalho da mulher e do menor. Programou-se, outrossim, para o ano seguinte, a convenção diplomática, que deveria ocorrer em Zurique. Todavia, a eclosão da Primeira Guerra Mundial impediu que essa última fosse realizada.

Mesmo durante o período em que ocorreu a Primeira Guerra Mundial (1914-1919), o movimento operário não arrefeceu, sendo inúmeros os registros de ações organizadas dos trabalhadores no referido período. Nesse contexto, merece especial destaque a atuação da entidade sindical American Federation of Labour (AFL) dos Estados Unidos que, em setembro de 1914, na Conferência Anual da Filadélfia, já havia adotado uma resolução sugerindo a realização de uma conferência de trabalhadores no mesmo local e ao mesmo tempo em que se efetuasse a conferência para elaboração do Tratado de Paz, com o escopo de se incluir no referido estatuto normas de proteção laboral. A citada resolução seria reafirmada nas Conferências Anuais da AFL subseqüentes, realizadas em São Francisco (1915) e em Baltimore (1916). ${ }^{16}$

As gestões da AFL serviram de inspiração aos movimentos de trabalhadores da Europa, sobretudo, à Conféderation Générale du Travail (CGT) francesa, que passou a defender, com vigor, a presença de delegados de organizações sindicais ao lado dos Estados, na elaboração do Tratado de Paz.

Organizou-se, dessa forma, a Conferência de Leeds (Inglaterra), de 1916, com a participação de representantes sindicais da Inglaterra, França, Bélgica e Itália. Nela aprovou-se uma resolução que mais tarde constituiria a base da parte do Tratado de Versalhes correspondente à criação da Organização Internacional do Trabalho. O preâmbulo da referida resolução, antes mesmo do término da Grande Guerra, proclamava:

A conferência declara que o tratado de paz que porá fim a esta guerra e dará às nações independência política e econômica deve também assegurar às classes trabalhadoras de todos os países um mínimo de garantias de ordem moral e material, relativas ao direito de associação, migração, seguro social, higiene, horas de trabalho e

\footnotetext{
${ }^{16}$ ARNALDO SÜSSEKIND, op. cit., p. p. 95-96 e WALKÜRE LOPES RIBEIRO DA SILVA, op. cit., p. 64.
} 
proteção, a fim de resguardá-las contra ataques oriundos da competição internacional capitalista.

Além disso, a mesma resolução recomendava a criação de um Bureau Internacional, encarregado de coordenar estudos e pesquisas sobre o desenvolvimento da legislação laboral em diversos países. ${ }^{17}$

As idéias defendidas na Conferência de Leeds foram apoiadas por representantes dos trabalhadores dos chamados países centrais e neutros ${ }^{18}$, nas Conferências de Estocolmo e Berna, ambas realizadas no ano de 1917. De igual forma, também foram reafirmadas por representantes de sindicatos e partidos socialistas dos países aliados na Conferência de Londres, em $1918 .^{19}$

Finalmente, merece destaque a Conferência Sindical Internacional de 1919, ocorrida em Berna, na qual aprovou-se a "Carta do Trabalho", que continha alguns dos princípios que mais tarde iriam ser consagrados no Tratado de Versalhes.

Agregados à forte agitação sindical experimentada no início do século XX, dois outros fatores influenciaram a inclusão de um estatuto que consagrasse normas de amparo ao trabalhador no Tratado de Paz: a Revolução Russa de 1917, que, como bem adverte WALKÜRE LOPES RIBEIRO DA SILVA, “contribuiria para reforçar nos trabalhadores a consciência de classe, alertando os governos para a necessidade de fazer concessões sob pena de ver comprometida sua própria sobrevivência"20; o envolvimento efetivo de um enorme contingente de trabalhadores com o conflito, o que constituiu um forte esteio para o atendimento de suas reinvindicações.

\subsection{O Tratado de Versalhes e a Criação da Organização Internacional}

\section{do Trabalho}

Todo o panorama brevemente relatado acima deixou claro que: o Tratado que poria fim à Primeira Guerra Mundial não poderia ser silente quanto à consagração de princípios fundamentais de proteção das relações de trabalho; a opinião pública mundial

\footnotetext{
${ }^{17}$ ARNALDO SÜSSEKIND, op. cit. (Direito Internacional...), p. 96.

${ }^{18}$ De acordo com AMÉRICO PLÁ RODRIGUES, os países centrais envolvidos na Guerra eram a Alemanha e a Áustria-Hungria; já os países neutros correspondiam a Suíça, Holanda, Suécia, Dinamarca e Noruega, in Los Convenios Internacionales del Trabajo, Montevidéu, Facultad de Derecho y Ciencias Sociales de la Universidad de la Republica, 1965, p. 39.

${ }^{19}$ NicOlas VALTiCOS, op. cit., p. p. 53-54.

${ }^{20}$ Op. cit., p. 64.
} 
estava convencida sobre a necessidade de se criar uma entidade internacional com a incumbência de promover a internacionalização das normas social-trabalhistas e, ao mesmo tempo, promover um controle sobre sua aplicação. ${ }^{21}$

Foi assim que, já na primeira sessão da Conferência de Preliminares da Paz, ocorrida em 25 de janeiro de 1919, no Palácio de Versalhes (França), designou-se uma Comissão de Legislação Internacional do Trabalho, sob a presidência de Samuel Gompers, líder da American Federation of Labour (AFL), e integrada por outros líderes trabalhistas e representantes governamentais. Mencionada comissão, após trinta e cinco sessões, concluiu, em 24 de março de 1919, o projeto que, com pequenas alterações, foi aprovado pela Conferência de Plenipotenciários e passou a constituir a Parte XIII do Tratado de Versalhes, cuja $1^{\mathrm{a}}$ Seção previu a criação da Organização Internacional do Trabalho e a $2^{\mathrm{a}}$ Seção enunciou os princípios fundamentais do Direito do Trabalho. ${ }^{22}$

No verão de 1920, foi fundada a sede da Organização Internacional do Trabalho, em Genebra (Suíça), país escolhido por ter sido o primeiro a se preocupar com o processo de regulamentação internacional das relações de trabalho, abrigar o escritório da Associação Internacional para Proteção Legal dos Trabalhadores e ser considerado o mais antimilitarista da Europa. A despeito da efetiva instalação da Organização Internacional do Trabalho ter ocorrido somente em 1920, sua primeira Conferência realizou-se, ainda, no ano de 1919, em Washington (Estados Unidos da América). ${ }^{23}$

Entre 1919 e 1939 a Organização Internacional do Trabalho promoveu vinte e cinco Conferências, em que foram aprovadas sessenta e sete Convenções Internacionais do Trabalho, muitas das quais, ainda, se encontram em vigência. ${ }^{24}$

Imprescindível, finalmente, que se ressalte que a Organização Internacional do Trabalho, ao ser criada no contexto da Conferência de Paz e por força do Pacto Internacional dela decorrente, nasceu, em tese, vinculada à Sociedade das Nações (art. 23 do Tratado de Versalhes). Todavia, é inegável que, desde seus primórdios, buscou afirmar-se como organização autônoma, admitindo como membros países que não pertenciam à Sociedade das Nações, tais como a Alemanha e a Áustria, logo no seu início e, posteriormente, a Argentina e os Estados Unidos. Demais disso, poucas foram efetivamente as intervenções da Sociedade das Nações nas atividades da Organização

\footnotetext{
${ }^{21}$ ARNALDO SÜSSEKIND, op. cit., p. 97.

${ }^{22}$ WAGNER DRDLA GIGLIO, $o p$. cit., p. 24 e ARNALDO SÜSSEKIND, op. cit., p. 101.

${ }^{23}$ ARNALDO SÜSSEKIND, op. cit., p. p. 105-107.

${ }^{24}$ Dados disponívies no sítio www.ilo.org. Acesso em 14/10/2008.
} 
Internacional do Trabalho, apesar do Tratado de Versalhes atribuir alguns poderes à primeira.

\subsection{A Segunda Guerra Mundial e a Vinculação da Organização Internacional do Trabalho à Organização das Nações Unidas como uma de suas Agências Especializadas}

Com o início da Segunda Guerra Mundial, a secretaria da Organização Internacional do Trabalho transferiu-se para Montreal (Canadá), em 1940, passando as suas Conferências a serem efetuadas no continente americano. Em 1941 ocorreu, em Nova York, uma Conferência Internacional do Trabalho, de caráter informal, que contou com a participação de trinta e três países, com o escopo de discutir, já naquele momento, as medidas que deveriam ser tomadas após o término do conflito, bem como, reavaliar as perspectivas e objetivos da Organização Internacional do Trabalho. ${ }^{25}$

Ainda em 1941, o presidente norte-americano Franklin Roosevelt proferiu seu famoso discurso das quatro liberdades em que exortava a cooperação internacional como instrumento de justiça social e, conseqüentemente, como um mecanismo necessário para assegurar a paz mundial. Nesse mesmo ano, foi firmado entre EUA e Inglaterra a Carta do Atlântico Norte, cujo texto proclamava, dentre outras coisas, a necessidade de colaboração entre as nações no campo econômico, com o intuito de se alcançar, em escala universal, a melhoria das normas de proteção ao trabalho, prosperidade econômica e segurança social. ${ }^{26}$

Nesse novo cenário, em que se afirmavam os princípios do Estado de BemEstar Social e uma nova dimensão das relações internacionais, fundada sob a ótica da cooperação entre os países, aconteceu a $26^{\mathrm{a}}$ Conferência Internacional do Trabalho, na cidade norte-americana de Filadélfia. Tal conferência foi marcada pela aprovação de uma Declaração que reafirmou e precisou os princípios da Organização Internacional do Trabalho, bem como, ampliou seus objetivos e, portanto, sua própria esfera de competência, passando referido organismo também a desempenhar o papel de "fomentar programas de cooperação técnica destinados a promover o bem-estar da humanidade". ${ }^{27}$

\footnotetext{
${ }^{25}$ WALKÜRE LOPES RIBEIRO DA SILVA, op. cit., p. 80.

${ }^{26}$ ARNALDO SÜSSEKIND, op. cit. (Direito Internacional...), p. 108.

${ }^{27}$ ARNALDO SÜSSEKIND, op. cit. (Direito Internacional...), p. 111.
} 
O fim da Guerra gerou alguma incerteza quanto à sobrevivência da Organização Internacional do Trabalho. O período foi marcado pelo declínio da Sociedade das Nações e o surgimento da Organização das Nações Unidas, que contava com um Conselho Econômico e Social, cujas atribuições seriam coincidentes, em certa medida, com as da Organização Internacional do Trabalho.

No entanto, a significativa produção normativa realizada pela Organização Internacional do Trabalho entre 1919 e 1939 aliada à autonomia que, de fato, sempre tal organismo buscou afirmar relativamente à Sociedade das Nações e, também, à adaptação de seus objetivos ao novo panorama político mundial justificaram a sua continuidade. Foi assim que na Conferência de São Francisco de 1945 aprovou-se uma proposta permitindo a execução das tarefas da Organização das Nações Unidas, no âmbito da cooperação econômica e social, em colaboração com a Organização Internacional do Trabalho, consubstanciada no art. 57 da Carta das Nações Unidas, que assim proclamava:

Os organismos especializados estabelecidos por acordos intergovernamentais que tenham amplas atribuições internacionais definidas em seus estatutos e relativas a matérias de caráter econômico, social, cultural, educativo, sanitário e outras conexas serão vinculadas à Organização (ONU) de acordo com as disposições do art. 63.

Abria-se, dessa forma, caminho para a vinculação da Organização Internacional do Trabalho à Organização das Nações Unidas e, via de conseqüência, à sobrevivência da primeira como instituição especializada para questões relativas à regulamentação internacional do trabalho e problemas conexos. Já na $27^{a}$ Sessão da Conferência Internacional do Trabalho, realizada em Paris, em novembro de 1945, foram aprovadas importantes resoluções que permitiriam a consecução desse objetivo. E, finalmente, em 30 de maio de 1946, em Nova York, foi assinado um acordo entre ambas as organizações, pelo qual se estabeleceu que: ${ }^{28}$

As Nações Unidas reconhecem a Organização Internacional do Trabalho como um organismo especializado, competente para empreender a ação que considere apropriada, de conformidade com seu instrumento básico, para cumprimento dos propósitos nele expostos.

${ }^{28}$ ARNALDO SÜSSEKIND, op. cit. (Direito Internacional...), p. 113. 
O acordo, adverte WALKÜRE LOPES RIBEIRO DA SILVA, estabeleceu uma coordenação das atividades de ambas as organizações em um plano de igualdade. Foi garantida a autonomia da Organização Internacional do Trabalho, que adquiriu, inclusive, personalidade jurídica internacional. A vinculação da Organização Internacional do Trabalho à Organização das Nações Unidas deu-se, portanto, de maneira diferente do que ocorrera no âmbito da Liga Nações, em que, no plano formal, a primeira era dependente da última. $^{29}$

\section{NATUREZA JURÍDica}

Diversas foram as tentativas de precisar a natureza jurídica da Organização Internacional do Trabalho. Na doutrina, o primeiro a se ocupar do tema foi MAURICE GUERREAU, para quem a Organização Internacional do Trabalho representou um elemento novo na esfera do Direito Público que rege as relações entre os Estados. Segundo o mesmo autor, as condições especiais que determinam o seu funcionamento a colocam em uma categoria a parte, que supera os limites do Direito Internacional e adentra o domínio do Direito Constitucional e do Direito Público: o Direito Administrativo Internacional. De acordo com tal entendimento, a OIT seria um ente de Direito Internacional, por agrupar um considerável número de Estados e, ao mesmo tempo, uma instituição de Direito Administrativo, por possuir numerosas atribuições de poder público puro. Esse poder, por sua vez, corresponderia ao resultado do desmembramento das atribuições dos poderes públicos nacionais dos países membros e restaria comprovado pela capacidade da OIT de tomar decisões de autoridade com força executória. ${ }^{30}$

Em sentido oposto, VILLARONGA sustentou que a Organização Internacional do Trabalho não teria o poder de aplicar coercitivamente suas decisões, uma vez que no campo internacional, a palavra final sobre a aplicação dessas medidas caberia a cada Estado. Dessa forma, a Organização Internacional do Trabalho nada mais seria do que um

\footnotetext{
${ }^{29}$ Op. cit., p. p. 82-83. Esclareça-se que o vínculo de dependência entre a Organização Internacional do Trabalho e a Sociedade das Nações era apenas formal, porque, como já referido alhures, do ponto de vista prático, a OIT, desde seus primórdios, gozou de certa autonomia, admitindo membros que não pertenciam à Sociedade das Nações e sofrendo poucas intervenções dessa última.

${ }^{30}$ L'Organisation Permanente du Travail, Librarie Arthur Rousseau, Paris, 1923, p.p. 41-59, apud AMÉRICO PlÁ RodRIGUEZ, op. cit., p. p. 201-203.
} 
organismo de cooperação internacional, particularmente adequado a realizar as tarefas que lhe foram delimitadas na parte XIII do Tratado do Versalhes. ${ }^{31}$

Para ERNEST MAHAIN a natureza jurídica da Organização Internacional do Trabalho seria a mesma da Sociedade das Nações, apresentando, em linhas gerais, as seguintes características: a) é uma liga de Estados que procura alcançar a justiça social, como mecanismo necessário a assegurar a paz universal; b) tem uma origem convencional, gerando obrigações somente aos Estados contratantes ou que a ela tenham aderido; c) as obrigações firmadas pelos Estados aderentes restringem suas respectivas soberanias; d) tem um caráter permanente. ${ }^{32}$

De acordo com GEORGES SCELLE, a Organização Internacional do Trabalho teria a natureza de um serviço público de legislação, de jurisdição e de coordenação administrativa da atividade econômica e social dos indivíduos e agentes públicos membros dessa sociedade internacional. ${ }^{33}$

IANOULOFF, por sua vez, defendeu a impossibilidade de se classificar a Organização Internacional do Trabalho dentre as categorias de Direito Internacional conhecidas até o período anterior à Primeira Guerra. Sustenta que, a exemplo da Sociedade das Nações, referida organização possui uma natureza jurídica sui generis. Ressaltou, ainda, que não era admissível apontá-la como um ente superestatal, já que suas disposições constitucionais respeitam a soberania dos Estados e a competência das autoridades legislativas nacionais. ${ }^{34}$

No mesmo sentido, AMÉRICO PlÁ RODRIGUEZ afirmou que a Organização Internacional do Trabalho tem importância suficiente para que seja estudada por si mesma, sem que haja a necessidade de relacioná-la a outros gêneros de institutos. ${ }^{35}$

Tais posições bem revelam o quão historicamente recente é o instituto da organização internacional para o Direito, o que justifica as divergências e as aparentes imprecisões das doutrinas supracitadas.

De fato, adverte Celso D. De Albuquerque Mello que "as organizações internacionais, como nós as entendemos hoje (com fins políticos, modos de decisão pela

\footnotetext{
${ }^{31}$ La Nature Juridique de l'Organisation Internationale du Travail in Revue Internationale du Travail, fev. 1924, t. IX, p. 203, apud, AMÉRICO PLÁ RoDRIGUEZ, op. cit., p. p. 203-205.

${ }^{32}$ L'Organisation Permanente du Travail in Recueil des Cours de l'Académie de Droit Internacional, Hachette, Paris, 1925, t. 4, p. 96 apud AMÉRICO Plá RODRIGUEZ, op. cit., p. p. 205-206.

${ }^{33}$ L'Organisation Internacional du Travail et le B.I.T., Librairie des Sciences Politiques et Sociales, Paris, 1930, p. 49, apud, AMÉRICO PLÁ RODRIGUEZ, op. cit., p. 207.

${ }^{34}$ Recueil des Cours de l'Academie de Droit International, 1935, p. 568, apud, AmÉRICo Plá RodRIGUEZ, op. cit., p. 207.

${ }^{35}$ Op. cit., p. 208.
} 
maioria, com poder regulamentar e personalidade internacional, etc.), só começaram a se desenvolver após a Primeira Guerra Mundial, com a criação da Liga das Nações”. ${ }^{36}$

Como visto anteriormente, a Organização Internacional do Trabalho teve sua origem associada ao surgimento da Sociedade das Nações. Representa, portanto, um dos marcos históricos do próprio desenvolvimento da categoria das organizações internacionais no universo jurídico. Natural, pois, que a definição da natureza jurídica dessa instituição tenha gerado controvérsias, sobretudo, no período que sucedeu imediatamente a sua criação.

Atualmente, entretanto, é possível afirmar, já com certa segurança, que as características das organizações internacionais encontram-se relativamente assentadas na doutrina e práticas internacionais. Com efeito, segundo a precisa definição de Angelo Piero Sereni, reproduzida por Celso D. DE AlbUQUERQue Mello:

(...) organização internacional é uma associação voluntária de sujeitos do direito internacional, constituída por ato internacional e disciplinada nas relações entre as partes por normas de direito internacional, que se realiza em um ente de aspecto estável, que possui um ordenamento jurídico interno próprio e é dotado de órgãos e institutos próprios, por meio dos quais realiza as finalidades comuns de seus membros mediante funções particulares e o exercício de poderes que lhe foram conferidos. ${ }^{37}$

As características da Organização Internacional do Trabalho se amoldam perfeitamente a tal categoria jurídica. Como exposto alhures, mencionado ente traduz uma associação de Estados (sujeitos típicos de Direito Internacional), fundada por meio de um ato internacional: o Tratado de Versalhes, que lhe conferiu atribuições e poderes específicos. Além disso, é um ente permanente, regido por um conjunto de normas jurídicas próprias (Constituição, Declarações, Resoluções, dentre outros instrumentos) e que possui órgãos e institutos próprios, tais como, a Conferência Internacional do Trabalho, o Conselho de Administração, o Bureau Internacional do Trabalho e a estrutura tripartite desses órgãos. Finalmente, e talvez o mais relevante, possui a Organização Internacional do Trabalho personalidade jurídica internacional, independente da de seus membros, característica que se tornou mais clara após a Segunda Guerra Mundial, quando houve a sua desvinculação da Sociedade das Nações e o reconhecimento expresso de sua autonomia.

${ }^{36}$ Curso de Direito Internacional Público, $1^{\circ}$ Vol., $4^{\text {a }}$ ed., Rio de Janeiro, Freitas Bastos, 1974, p. 326.

${ }^{37}$ Op. cit., p. 314. 


\section{OBjetivos}

A parte XIII do Tratado de Versalhes de 1919, logo em seu preâmbulo, já revelava quais seriam os objetivos da Organização Internacional do Trabalho, ao proclamar:

Considerando que a Sociedade das Nações tem por objetivo estabelecer a paz universal e que tal paz não pode ser fundada senão sobre a base da justiça social; em atenção a que existem condições de trabalho que implicam para um grande número de pessoas em injustiça, miséria e privações e que origina tal descontentamento que a paz e a harmonia universais correm perigo em vista de que é urgente melhorar essas condições (por exemplo, no que concerne à regulamentação das horas de trabalho, à fixação de uma duração máxima da jornada e da semana de trabalho, ao aproveitamento da mão-de-obra, à luta contra o desemprego, à garantia de um salário que assegure condições convenientes de existência, à proteção dos trabalhadores contra as enfermidades gerais ou profissionais e os acidentes resultantes do trabalho, à proteção das crianças, dos adolescentes e das mulheres, às pensões de velhice e de invalidez, à defesa dos interesses dos trabalhadores ocupados no estrangeiro, à afirmação do princípio da liberdade sindical, à organização do ensino profissional e técnico e outras medidas análogas); tendo presente que a não adoção por uma nação qualquer de um regime de trabalho realmente humanitário é um obstáculo aos esforços das demais desejosas de melhorar a sorte dos trabalhadores nos seus próprios países; as Altas Partes Contratantes, movidas por sentimento de justiça e humanidade, assim como pelo desejo de assegurar uma paz duradoura e mundial, convencionaram o que segue.

Segundo leciona NiCOLAS VALTiCos, tal preâmbulo continha o essencial da tríplice justificação de uma ação legislativa internacional sobre as questões de trabalho: política (assegurar bases sólidas para a paz universal), humanitária (existência de condições de trabalho que geram injustiça, miséria e privações) e econômica (o argumento inicial da concorrência internacional como obstáculo para melhoria das condições sociais em escala nacional, ainda que invocado agora em último lugar). ${ }^{38}$

Dentre os motivos apresentados no preâmbulo transcrito, que determinaram a criação da Organização Internacional do Trabalho e que, ainda hoje, constituem alguns dos objetivos principais dessa organização, avultam, como de maior relevo, a preocupação

\footnotetext{
${ }^{38}$ Op. cit., p. 67.
} 
em se garantir um padrão mínimo de condições de trabalho como mecanismo assecuratório de dignidade humana e, como decorrência do primeiro, a preocupação em se garantir a paz universal. $^{39}$

Tal precedência transparece por meio da análise do art. 427 do Tratado de Versalhes, que enuncia os princípios fundamentais do Direito do Trabalho, adotando a seguinte redação:

As Altas Partes contratantes, reconhecendo que o bem-estar físico, moral e intelectual dos trabalhadores industriários é de importância essencial do ponto de vista internacional, criaram um organismo permanente associado à Sociedade de Nações.

Reconhecem que as diferenças do clima, usos e costumes, de oportunidade econômica e de tradição industrial tornam difícil alcançar, de maneira imediata, a uniformidade absoluta nas condições de trabalho. Entretanto, persuadidos de que o trabalho não há de ser considerado simplesmente como um artigo de comércio, pensam que existem métodos e princípios para a regulamentação das condições de trabalho que todas as comunidades industriais deverão esforçar-se em aplicar, enquanto as circunstâncias especiais em que possam encontrar-se o permitam.

Entre esses métodos e princípios, as Altas Partes contratantes opinam que os seguintes têm uma importância especial e urgente:

$1^{\circ}$. O princípio diretivo antes enunciado de que o trabalho não há de ser considerado como mercadoria ou artigo de comércio.

$2^{\circ}$. O direito de associação visando a alcançar qualquer objetivo não contrário às leis, tanto para os patrões como para os assalariados.

$3^{\circ}$. O pagamento aos trabalhadores de um salário que lhes assegure um nível de vida conveniente, em relação com sua época e país.

$4^{\circ}$. A adoção da jornada de oito horas ou as 48 horas semanais, com o objetivo a alcançar-se onde ainda não se haja logrado.

$5^{\circ}$. A adoção de um descanso semanal de 24 horas, sempre que possível aos domingos.

$6^{\circ}$. A supressão do trabalho das crianças e a obrigação de impor aos trabalhos dos menores de ambos os sexos as limitações necessárias para permitir-lhes continuar sua instrução e assegurar seu desenvolvimento físico.

$7^{\circ}$. O princípio do salário igual, sem distinção de sexo, para um trabalho de igual valor.

\footnotetext{
${ }^{39}$ Nesse sentido, Celso D. DE AlbuQuerque Mello afirma que "na OIT sempre se procurou diminuir o argumento da concorrência internacional como a justificando. A concorrência perde a sua razão de ser se levarmos em consideração que a OIT trata de países em condições econômicas diferentes. A sua razão de ser é a paz universal e a justiça social".
} 
$8^{\circ}$. As leis promulgadas em cada país, relativa às condições de trabalho deverão assegurar um tratamento econômico eqüitativo a todos os trabalhadores que residam legalmente no país.

$9^{\circ}$. Cada Estado deverá organizar um serviço de inspeção, que inclua mulheres, a fim de assegurar a aplicação das leis e regulamentos para a proteção dos trabalhadores.

Sem proclamar que esses princípios e métodos são completos ou definitivos, as Altas Partes contratantes entendem que servem para guiar a política da Sociedade das Nações e que, se forem adotados pelas comunidades industriais que são membros da Sociedade das Nações e mantidos completos na prática, por um corpo apropriado de inspetores, beneficiarão profundamente os assalariados do mundo.

O princípio insculpido no item $1^{\circ}$ acima reproduzido, em conformidade com MARIo DE LA Cueva, “contém a essência do Direito do Trabalho: o trabalho não é uma mercadoria; equivale a sustentar que, em todos os casos, deve respeitar-se a dignidade da pessoa humana". ${ }^{40}$ Os demais, como corolários do primeiro, objetivam, claramente a criação de um patamar mínimo de proteção ao trabalhador como forma de garantir-lhe tal dignidade.

Antevendo a conveniência e necessidade de rever os princípios cardeais que deveriam nortear a sua atuação após a Segunda Guerra Mundial, a Organização Internacional do Trabalho, em 1944, realizou, na cidade norte-americana da Filadélfia, a sua 26a sessão da Conferência, tendo sido aprovada a Declaração referente aos fins e objetivos da Organização Internacional do Trabalho, também conhecida como Declaração da Filadélfia. Tal declaração, preparada pelo jurista e sociólogo inglês Wilfred Jenks,

(...) repetiu, precisou e ampliou os princípios do Tratado de Versalhes sob o influxo da idéia de cooperação internacional para a consecução da segurança social de todos os seres humanos. Depois de reafirmar a estrutura tripartite e o princípio de que a justiça social é a base da paz, ampliou a competência da OIT, conferindo-lhe o encargo de fomentar programas de cooperação técnica destinados a promover o bem-estar da humanidade; e, em virtude da interdependência de problemas cujas soluções podem ocorrer para o bem-estar material e espiritual do homem, realçou a colaboração da OIT com os demais organismos internacionais, aos quais deveria ser confiada parte dessa gigantesca tarefa". ${ }^{41}$

${ }^{40}$ Derecho Mexicano del Trabajo, vol. I, 2 ed., México, 1943, p. 276, apud ARANLDo SÜSSEKIND, op. cit. (Direito Internacional...), p. 103.

${ }^{41}$ ARnAldo SüSSEKIND, Convenções da OIT, 2a ed., São Paulo, LTr, 1998, p. 20. 
A Declaração da Filadélfia de 1944 foi anexada à Constituição da Organização Internacional do Trabalho, como resultado da revisão constitucional de 1946. A conseqüência dessa incorporação, assinala AMÉRICO PLÁ RODRIGUEZ, foi a ampliação do campo de ação dessa organização, que passou a se estender aos "problemas econômicos e financeiros, tão estritamente vinculados aos problemas sociais." 42

Na visão de NiCOLAS VALTiCOS, a revisão da Constituição da Organização Internacional do Trabalho, operada em 1946, representou a adoção de uma nova filosofia por tal organização, sintetizada pelas seguintes características:

a) o objetivo da OIT não se restringe a melhorar as condições de trabalho, mas a melhorar a condição humana no seu conjunto;

b) a OIT não procura unicamente a melhoria das condições materiais de existência. Ela dá ênfase tanto à luta contra a necessidade, visando ao progresso material e à segurança econômica, como à defesa dos valores da liberdade - notadamente da liberdade de expressão e de associação - de dignidade e de igualdade - em particular da igualdade de oportunidades, independentemente da raça, da crença ou do sexo;

c) a ação da Organização não se limita à proteção dos trabalhadores propriamente ditos, porquanto alcança o conjunto dos seres humanos nas suas relações com o trabalho;

d) os textos fundamentais da OIT insistem na necessidade de um esforço concentrado, internacional e nacional, para promover o bem comum, isto é, para assegurar o bem-estar material e espiritual da humanidade;

e) esses princípios de base da OIT sublinham que a ação para melhorar as condições sociais da humanidade, no sentido mais amplo do termo, não deve constituir um setor distinto das políticas nacionais ou da ação internacional, pois representa o próprio objeto dos programas econômicos e financeiros e que estes devem ser julgados por esse prisma. Afirma-se, assim, a primazia do social em toda planificação econômica e a finalidade social do desenvolvimento econômico. ${ }^{43}$

Em suma, os objetivos da Organização Internacional do Trabalho transcendem à criação de uma legislação internacional destinada à regulação das condições de trabalho, abrangendo também uma série de ações tendentes a melhorar as condições sociais da humanidade e, nesse sentido, garantir a todos condições adequadas de vida.

\footnotetext{
${ }^{42}$ Op. cit., p. 449.

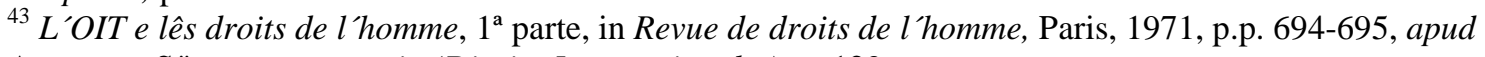
ARNALDO SÜSSEKIND, op. cit. (Direito Internacional...), p. 129.
} 


\section{Membros}

Como exposto no tópico referente à sua natureza jurídica, a Organização Internacional do Trabalho é composta por uma associação de Estados, emanada de um Pacto Internacional firmado no contexto da Conferência de Paz, logo após o término da Primeira Guerra Mundial. O Tratado de Versalhes, como ficou conhecido, fundou a Sociedade das Nações e estabeleceu, em seu art. 387, que a qualidade de membro desta implicaria, automaticamente, a qualidade de membro da Organização Internacional do Trabalho.

Todavia, desde o início de sua existência, a Organização Internacional do Trabalho pautou-se pela universalidade de sua atuação e afirmação de sua autonomia, razão pela qual admitiu como membros, ainda em 1919, a Alemanha e a Áustria, que não faziam parte da Sociedade das Nações. Anos mais tarde, permitiu a permanência de países que haviam se retirado da Sociedade das Nações, como os EUA, a URSS, o México e a Argentina.

Ao término da Segunda Guerra Mundial, a Organização Internacional do Trabalho passou a vincular-se à Organização das Nações Unidas como uma de suas agências especializadas. Em 1946 operou-se a revisão da Constituição da OIT, passando o art. $1^{\circ}, \S \S 2^{\circ}, 3^{\circ}$ e $4^{\circ}$ do atual texto a dispor sobre os critérios para a determinação de seus membros, nos seguintes termos:

2. Serão Membros da Organização Internacional do Trabalho os Estados que já o eram a $1^{\circ}$ de novembro de 1945 , assim como quaisquer outros que o venham a ser, de acordo com os dispositivos dos parágrafos $3^{\circ}$ e $4^{\circ}$ do presente artigo.

3. Todo Estado-Membro das Nações Unidas, desde a criação desta instituição e todo Estado que for a ela admitido, na qualidade de Membro, de acordo com as disposições da Carta, por decisão da Assembléia Geral, podem torna-se Membros da Organização Internacional do Trabalho, comunicando ao Diretor-Geral da Repartição Internacional do Trabalho que aceitou, integralmente, as obrigações decorrentes da Constituição da Organização Internacional do Trabalho.

4. A Conferência Geral da Organização Internacional do Trabalho tem igualmente poderes para conferir a qualidade de Membro da Organização, por maioria de dois terços do conjunto dos votos presentes, se a mesma maioria prevalecer entre os votos dos delegados governamentais. A admissão do novo Estado-Membro tornar-se-á efetiva quando ele houver comunicado ao Diretor-Geral da Repartição Internacional do Trabalho que aceita integralmente as obrigações decorrentes da Constituição da Organização. 
Atualmente, a Organização Internacional do Trabalho conta com 181 países membros $^{44}$, o que, sem dúvida, confere ao referido ente o caráter de universal. O status de membro permite ao Estado o direito de participar da Conferência Internacional do Trabalho e de funcionar nos demais órgãos para os quais for eleito ou designado. Ao mesmo tempo, implicam-lhe obrigações frente à instituição, dentre as quais merecem destaque a de contribuir financeiramente para o custeio da Organização; a de submeter à autoridade nacional competente as convenções e recomendações aprovadas na Conferência; a de enviar relatórios e informações previstas na Constituição da OIT ao Bureau Internacional do Trabalho. ${ }^{45}$

Assiste aos países membros o direito de retirar-se da Organização Internacional do Trabalho, ainda que permaneçam integrados à Organização das Nações Unidas. Todavia, existem certas condições para o exercício desse direito, que se encontram expressos no $\S^{\circ}$ do art. $1^{\circ}$ da Constituição da OIT, da seguinte forma:

\section{Nenhum Estado-Membro da Organização Internacional do Trabalho} poderá retirar-se sem o aviso prévio ao Diretor-Geral da Repartição Internacional do Trabalho. A retirada tornar-se-á efetiva dois anos depois que este aviso prévio houver sido recebido pelo Diretor-Geral, sob condição de que o Estado-Membro haja, nesta data, preenchido todas as obrigações financeiras que decorrem da qualidade de Membro. Esta retirada não afetará, para o Estado-Membro que houver ratificado uma convenção, a validez das obrigações desta decorrentes, ou a ela relativas, durante o pedido previsto pela mesma convenção.

Não existe, por seu turno, um mecanismo de exclusão compulsória de membros no âmbito da Organização Internacional do Trabalho. ${ }^{46}$ Há, porém, previsão no sentido de suspender o direito de voto, em caso de atraso do pagamento da contribuição financeira, traduzida do preceptivo da Constituição da OIT abaixo transcrito:

\footnotetext{
${ }^{44}$ Número de membros em 29/01/2007. Fonte: http://www.ilo.org. Acesso em 14/10/2008.

${ }^{45}$ ARNALDO SÜSSEKIND, op. cit.(Direito Internacional...), p. p. 133-134.

${ }^{46}$ Registre-se que, em 1964, a Conferência Internacional do Trabalho aprovou uma emenda à Constituição da OIT, prevendo a possibilidade de exclusão ou suspensão de membro que houver, respectivamente, sido excluído ou suspenso da ONU. Contudo, tal emenda não chegou a entrar em vigor, porquanto, não atendeu ao disposto no art. 36 da Constituição da Organização Internacional do Trabalho que vincula a eficácia jurídica das emendas à necessidade de ratificação ou aceitação de dois terços dos membros, nele incluídos, pelo menos cinco membros representados no Conselho de Administração como de maior importância industrial.
} 


\section{(...)}

4. Qualquer Estado-Membro da Organização, cuja dívida em relação a esta seja, em qualquer ocasião, igual ou superior ao total da contribuição que deveria ter pago nos dois anos completos anteriores, não poderá tomar parte nas votações da Conferência, do Conselho de Administração ou de qualquer comissão, ou nas eleições para o Conselho de Administração. A Conferência pode, entretanto, por maioria de dois terços dos votos presentes, autorizar o Estado em questão a tomar parte na votação, ao verificar que o atraso é devido a motivo de força maior.

Finalmente, cumpre ressaltar que a Constituição da Organização Internacional do Trabalho contempla, ainda, a hipótese de readmissão de membros, ao dispor no $\S 6^{\circ}$ do art. $1^{\circ}$ que: "quando um Estado houver deixado de ser Membro da Organização, sua readmissão nesta qualidade, far-se-á de acordo com os dispositivos dos parágrafos $3^{\circ}$ e $4^{\circ}$ do presente artigo".

\section{ESTRUTURA}

\section{1. A Estrutura Tripartite}

Uma das características mais singulares da Organização Internacional do Trabalho é a composição tripartida de seus principais órgãos deliberantes, que contam não apenas com delegados governamentais, mas também com representantes de entidades de empregadores e trabalhadores. Tal ocorre, por exemplo, com a Conferência Internacional do Trabalho, na qual cada delegação nacional possui dois representantes do governo, um representante dos trabalhadores e um dos empregadores, bem como, com o Conselho de Administração e com diversas comissões da Organização Internacional do Trabalho.

ARNALDO SÜSSEKIND destaca que a estrutura tripartite não se verifica em órgãos que digam respeito a interesses específicos de governo (v.g. a Comissão de Representantes Governamentais para Questões Financeiras, da Conferência) ou que se relacionem ao exame de questões técnicas (v.g. o Comitê de Peritos para a avaliação dos dez Estados de importância industrial mais considerável, constituído geralmente de 
estatísticos) ou jurídicas (v.g. a Comissão de Peritos na Aplicação das Convenções e Recomendações, integrada por personalidades independentes). ${ }^{47}$

De outra parte, algumas comissões paritárias, como aquelas destinadas a assuntos marítimos e assuntos relativos à função pública, também seriam exemplos de exceção à regra do tripartismo. ${ }^{48}$

A justificativa para a adoção desse modelo foi explicado, com precisão, por WAGNER D. GILGLIO para quem

(...) a participação de elementos governamentais era essencial à consecução do objetivo visado, pois sem eles as resoluções de empregados e empregadores não obteriam força vinculativa interna, nos diversos Estados. Por outro lado, a exclusão das classes diretamente interessadas na regulamentação, além de ensejar soluções diplomáticas alheadas da realidade, acarretaria a desconfiança de empresários e trabalhadores e a ineficiência prática de tratados meramente programáticos. ${ }^{49}$

O fato é que para a Organização Internacional do Trabalho a estrutura tripartite constitui uma fonte de inquestionável força, tornando-a aberta à participação da sociedade civil no plano de suas atividades mais relevantes (sobretudo, a normativa), o que confere às suas decisões um maior grau de legitimidade e, conseqüentemente, também um maior grau de autoridade e eficácia.

Há, naturalmente, certas dificuldades atreladas a esse sistema: divergências ideológicas e de interesses que podem diminuir uma ação rápida e eficaz, ou, simplesmente, diluir o conteúdo dos instrumentos normativos adotados; problemas de representação de trabalhadores, tanto em países onde exista o pluralismo sindical, como em países que não respeitam integralmente a liberdade de associação; problemas de representação de empregadores, sobretudo, do ponto de vista histórico, dos países socialistas. ${ }^{50}$

Em que pesem tais problemas, observa-se uma forte tendência em fortalecer o tripartismo, não apenas no plano de atuação da Organização Internacional do Trabalho, como também, na esfera de ação dos Estados. Nesse sentido, A Conferência Internacional do Trabalho aprovou, em 1960, a Recomendação n. 113, pela qual incentiva a prática do

\footnotetext{
${ }^{47}$ Op. cit. (Direito Internacional...), p. 148.

${ }^{48}$ NiCOLAS VALTiCOS, op. cit., p. 201

${ }^{49}$ Op. cit., p. 31.

50 Geraldo W. von Potobsky e HéCtor G. Bartolomei de la CruZ, op. cit., p. 14-17 e NicOlas VALTICOS, op. cit., p. 201-210.
} 
tripartismo no plano nacional. Já em 1971, a Conferência aprovou importante resolução reforçando a estrutura tripartite no seio da própria Organização Internacional do Trabalho. Em 1976, foram aprovadas a Convenção n. 144 e a Recomendação n. 152, ambas prevendo aos Estados procedimentos que assegurem consultas efetivas entre os representantes do governo, dos empregadores e dos trabalhadores sobre os assuntos relacionados com as atividades da Organização Internacional do Trabalho. Finalmente, em 1977, a Conferência editou nova Resolução acerca de tal assunto.

\section{2. Órgãos}

A estrutura básica da Organização Internacional do Trabalho foi descrita no art. $2^{\circ}$ de sua Constituição, mantendo-se, praticamente, a mesma até hoje. Compõe-se dos seguintes órgãos: Conferência Internacional do Trabalho, Conselho de Administração e Bureau ou Repartição Internacional do Trabalho.

Além desses órgãos, a Organização Internacional do Trabalho conta, ainda, com um Instituto Internacional de Estudos Trabalhistas, com sede em Genebra (Suíça); com um Centro Internacional de Aperfeiçoamento Profissional e Técnico, sediado em Turim (Itália); com um Tribunal Administrativo, constituído por juízes nomeados pela Conferência, a quem compete decidir litígios ajuizados por funcionários da própria Organização e por entidades internacionais que lhe reconhecem formalmente sua competência, tais como a OMS, a UNESCO, FAO, GATT; com comissões e comitês que funcionam junto ao Conselho de Administração, à Repartição Internacional do Trabalho e a outros organismos internacionais, como a ONU, a OMS e a UNESCO. ${ }^{51}$

\subsubsection{Conferência Internacional do Trabalho}

A Conferência Internacional do Trabalho é o órgão supremo da Organização, correspondendo à assembléia geral de todos os Estados-Membros que a compõem. Suas atribuições são, em síntese: traçar as diretrizes gerais da política social a ser observada; elaborar, por meio de convenções e recomendações, a regulamentação internacional do trabalho e das questões que lhe são conexas; adotar resoluções sobre problemas que concernem, direta ou indiretamente, às suas finalidades e competência;

\footnotetext{
${ }^{51}$ ARNALDO SÜSSEKIND, op. cit. (Direito Internacional...), p. 147.
} 
aprovar o orçamento da entidade, vinculado ao programa de suas atividades; resolver as questões referentes à inobservância, por parte dos Estados-Membros, das normas constitucionais e das convenções ratificadas. ${ }^{52}$

A composição da Conferência observa o princípio do tripartismo, tendo cada Estado membro uma delegação formada por dois representantes governamentais, e dois classistas, designados pelos países de acordo com suas organizações profissionais mais representativas de trabalhadores e empregadores (art. $3^{\circ}, \S \S 1^{\circ}$ e $5^{\circ}$, da Constituição da OIT). Cada um dos delegados nacionais tem o direito de votar individualmente sobre todas as questões submetidas à Conferência (art. $4^{\circ}, \S 1^{\circ}$, da Constituição da OIT), sendo comum que os delegados classistas votem diferentemente uns dos outros e também dos delegados governamentais. Caso alguma delegação mostre-se incompleta, há previsão no sentido de que o delegado não governamental que esteja presente tenha o direito de participar das discussões, mas não de votar, como modo de se equilibrar os votos de trabalhadores e empregadores ( $\operatorname{art.} 4^{\circ}, \S 2^{\circ}$, da Constituição da OIT).

Os quatro delegados referidos (governamentais e classistas) podem, ainda, fazer-se acompanhar de conselheiros técnicos, com o escopo de assegurar a representação de cada um deles em todas as comissões que compõem a Conferência. O número máximo de conselheiros é de, no máximo, dois por delegado e por matéria inscrita na ordem do dia (art. $3^{\circ}, \S 2^{\circ}$, da Constituição da OIT).

Cumpre registrar que os poderes dos delegados e de seus respectivos conselheiros técnicos são examinados pela Comissão de Verificação de Poderes, constituída pela Conferência e com composição igualmente tripartida (um representante governamental, um dos trabalhadores e outro dos empregadores). Além dessa comissão, a Conferência constitui diversas outras que realizam um exame das questões que lhes são submetidas e, ao final dos trabalhos, apresentam seus resultados ao Plenário da Conferência. Referidas comissões, por sua vez, também têm uma estrutura tripartida, à exceção da Comissão de Questões Financeiras, que é composta somente de representantes governamentais.

Como observado por ARNALDO SüSSEKIND, a natureza jurídica da Conferência Internacional do Trabalho é sui generis, não correspondendo a um conclave de plenipotenciários, tampouco a uma reunião de técnicos. ${ }^{53}$ Mais uma vez, a estrutura tripartite, característica marcante de toda a Organização Internacional do Trabalho, coloca

\footnotetext{
${ }^{52}$ ARNALdO SÜSSEKIND, op. cit. (Convenções...), p. 21.

${ }^{53}$ Op. cit. (Direito Internacional...), p. 154.
} 
a Conferência em uma posição única no Direito Internacional Público. Há quem defenda, como Maurice Guerreau, que a Conferência corresponderia a uma espécie de parlamento mundial integrado por um sistema de representação mista de interesses: estatais e profissionais. ${ }^{54}$ Todavia, cabe aqui a advertência de que a eficácia da produção normativa da entidade estaria condicionada ao processo de ratificação a ser realizado no seio de cada Estado membro, não se podendo falar, propriamente de um parlamento superestatal.

\subsubsection{Conselho de Administração}

O Conselho de Administração é o órgão executivo colegiado de direção superior da Organização Internacional do Trabalho. Atualmente, é ele constituído por cinqüenta e seis membros, dos quais, vinte e oito são representantes governamentais, quatorze representantes de empregadores e quatorze representantes de trabalhadores. Dentre os representantes governamentais, dez deles correspondem aos Estados de importância industrial mais considerável ${ }^{55}$, ao passo que os demais, bem como, os representantes classistas, são eleitos trienalmente pelos respectivos grupos na Conferência.

As principais atribuições do Conselho são, em suma: fixar a data, o local e a ordem do dia da Conferência Geral, das conferências regionais e das conferências técnicas; eleger o Diretor-Geral da Repartição Internacional do Trabalho; designar os dez países que o integram como membros não-eletivos; elaborar o projeto de programa e de orçamento da Organização, a ser submetido à Conferência Geral; instituir comissões permanentes ou especiais; deliberar sobre os relatórios e conclusões das suas comissões, inclusive dos oriundos do Comitê de Liberdade Sindical atinentes às queixas por violação de direitos sindicais; adotar as medidas previstas na Constituição em caso de reclamação ou queixa contra um Estado-Membro por inobservância de convenção que haja ratificado. ${ }^{56}$

O Conselho de Administração deverá eleger, dentre seus membros, um presidente e dois vice-presidentes, observado, em tal escolha, o princípio do tripartismo, ou

\footnotetext{
${ }^{54}$ Op. cit., p. 43 apud AMÉRICO PlÁ RODRIGUEZ, op. cit., p. 152.

55 De acordo com ARNALDO SÜSSEKIND, "para a elaboração da lista dos 10 países de importância industrial mais considerável, os Comitês de Peritos Estatísticos designados em cada oportunidade, com o endosso do CA [Conselho de Administração], tem computado apenas os dados referentes à renda nacional e à população economicamente ativa, atribuindo a este o peso 1 e àquela o peso 3 ". Até o encerramento da $3^{\mathrm{a}}$ edição de seu livro Direito Internacional do Trabalho (2000), SüSSEKIND indica que esses países seriam: Alemanha, Brasil, China EUA, França, Índia, Itália, Japão, Reino Unido e Rússia. In op. cit. (Direito Internacional...), p. p. 167-168.

${ }^{56}$ ARNALDO SÜSSEKIND, op. cit. (Convenções ...), p. p. 22-23.
} 
seja, dentre essas pessoas, uma deverá ser um representante governamental, outra um representante dos empregados e outra dos empregadores (art. $7^{\circ}, \S 7^{\circ}$, da Constituição da OIT). Além disso, deverá estabelecer seu próprio regulamento e reunir-se nas épocas que determinar, podendo realizar sessões especiais sempre que, no mínimo, dezesseis de seus membros realizarem um pedido, por escrito, nesse sentido $\left(\operatorname{art} .7^{\circ}, \S 8^{\circ}\right.$, da Constituição da OIT).

Por derradeiro, cumpre consignar que o Conselho de Administração pode instituir diversas comissões, subcomissões e grupos de trabalho para assessorá-lo, tendo alguns, caráter permanente e outros, uma duração episódica. Atualmente, o Conselho de Administração possui as seguintes comissões e subcomissões: Comissão de Programa, Orçamento e Administração; Subcomissão de Construções; Subcomissão das Tecnologias da Informação e Comunicação; Comissão de Questões Jurídicas e Normas Internacionais do Trabalho; Subcomissão de Empresas Multinacionais; Comissão de Emprego e Política Social; Comissão de Reuniões Setoriais, Técnicas e Questões Afins; Comissão de Cooperação Técnica; Grupo de Trabalho sobre a Dimensão Social da Mundialização. ${ }^{57}$

\subsubsection{Repartição Internacional do Trabalho}

A Repartição ou Bureau Internacional do Trabalho corresponde ao secretariado técnico-administrativo da Organização Internacional do Trabalho. Tem ele caráter permanente e foi inspirado no Escritório Internacional do Trabalho, criado pela Associação Internacional para Proteção Legal dos Trabalhadores. ${ }^{58}$ Tal órgão é dirigido por um Diretor-Geral, eleito pelo Conselho de Administração, com periodicidade geralmente de cinco anos, de quem recebe instruções e perante o qual é responsável (art. $8^{\circ}$ da Constituição da OIT).

O Diretor-Geral exerce suas atribuições com a colaboração de um Conselheiro Jurídico e de Diretores-Gerais Adjuntos, além de Subdiretores-Gerais que coordenam atividades regionais.

$\mathrm{Na}$ sede da Repartição, em Genebra, funcionam departamentos que compõem os seus setores técnico, administrativo e de relações, além de algumas Comissões e Comitês (v.g., a Comissão de Peritos na Aplicação de Convenções e Recomendações).

\footnotetext{
${ }^{57}$ Fonte: http://www.ilo.org. Acesso em 2/09/2008.

${ }^{58}$ WALKÜRE LOPES RIBEIRO DA SILVA, op. cit., p. 95.
} 
Finalmente, nas diferentes regiões foram instalados escritórios de enlace, administrados pelos mencionados Subdiretores-Gerais, aos quais se reportam os diretores de escritórios ou os correspondentes sediados em quase todos os Estados-Membros.

Dentre as inúmeras atribuições desempenhadas pela Repartição Internacional do Trabalho, merecem especial destaque: os estudos sobre cada um dos temas da ordem do dia das Conferências e reuniões de Comissões; a assessoria que, por meio do Departamento de Normas Internacionais, dá a essas Conferências e reuniões, bem como, à Comissão de Peritos na Aplicação de Convenções e Recomendações; as publicações periódicas e eventuais a respeito de questões de interesse da Organização Internacional do Trabalho; a execução de programas de atividades práticas e cooperação técnica, em colaboração com entidades de diversos tipos e as autoridades nacionais interessadas. $^{59}$

\section{ATIVIDADES DESENVOLVIDAS}

Assinalam Geraldo W. von Potobsky e HÉctor G. BARTOLOMEI DE LA CRUZ que os métodos de ação da Organização Internacional do Trabalho podem ser reunidos em três grupos principais: o normativo, o da cooperação técnica e o da investigação e divulgação. Segundo os autores, todas essas atividades possuem vínculos estreitos e se complementam. ${ }^{60}$ Lado a lado com esses grupos de funções desenvolvidas pela Organização Internacional do Trabalho, pode-se colocar também a atividade de supervisão ou controle da aplicação das normas internacionais do trabalho.

\subsection{Atividade Normativa}

A atividade normativa pode ser considerada não apenas a principal função da Organização Internacional do Trabalho, mas a razão de ser de sua própria criação. De fato, o desenvolvimento de tal atividade "dimana da essência mesmo da instituição, de sua estrutura, de seus objetivos de suas ambições: promover a justiça social em condições tais que permitam evitar a concorrência desleal entre as nações". 61

\footnotetext{
59 ARNALDO SÜSSEKIND, op. cit. (Convenções...), p. 23.

${ }^{60}$ Op. cit., p. 19.

${ }^{61}$ FRANCIS BLANCHARD, Memoria del Diretor General - 70 Reunión de la Conferência, Genebra, 1984, p. V, apud ARNALDO SÜSSEKIND, op. cit. (Direito Internacional...), p. 180.
} 
Compete, primordialmente, à Conferência Internacional do Trabalho, como assembléia geral da instituição, desempenhar o papel de elaborar e aprovar as normas internacionais do trabalho. Essa atividade efetiva-se, sobretudo, por meio de convenções e recomendações, cujos efeitos encontram-se previstos na Constituição da Organização Internacional do Trabalho, à qual os países aderem, por ato voluntário e soberano, quando se filiam à Organização.

A par das convenções e recomendações, existem outros instrumentos que complementam a função normativa da Organização Internacional do Trabalho. Dentre eles, LuCIANE CARDOSO BARZOTTO relaciona os seguintes: a própria Constituição da OIT; protocolos; declarações; resoluções; orientações; trabalhos dos órgãos de supervisão da OIT; documentos autorizados. ${ }^{62}$

Atualmente, o conteúdo da Constituição da Organização Internacional do Trabalho corresponde, em linhas gerais, ao que dispunha os arts. 387 a 427 do Tratado de Versalhes, com as alterações trazidas pelas emendas constitucionais de 1922, 1934, 1945, 1946, 1953, 1962 e 1972. Dentre essas alterações, a principal, sem dúvida, foi a realizada pela reforma de 1946, que acabou por integrar como anexo à Constituição da Organização Internacional do Trabalho a Declaração da Filadélfia de 1944.

A Constituição é a fonte primária da qual emanam as demais normas produzidas no seio da Organização. Contudo, não se pode colocar a Constituição originalmente concebida como um instrumento derivado da atividade normativa da OIT, uma vez que ela foi o próprio pressuposto de existência dessa última. Em outros termos, foram os dispositivos da Parte XIII do Tratado de Versalhes que deram origem e conformação à OIT, inclusive quanto à sua função de criar normas internacionais do trabalho, e não o contrário.

Em contrapartida, as emendas constitucionais que atualizaram o conteúdo da Constituição são, indubitavelmente, produto da ação normativa da Organização Internacional do Trabalho, uma vez que se operaram de acordo com o procedimento definido em seu art. 36 e no âmbito da Conferência Internacional do Trabalho.

As convenções internacionais da OIT, principais instrumentos da regulamentação internacional do trabalho, serão objeto de uma detida investigação a ser realizada em capítulo específico. Por ora, com o intuito de distingui-las das recomendações, convém apenas destacar que as convenções são textos aprovados pelo

${ }^{62}$ Direitos Humanos e Trabalhadores - Atividade Normativa da Organização Internacional do Trabalho e os Limites do Direito Internacional do Trabalho, Porto Alegre, Livraria do Advogado, 2007, p. 86. 
quórum qualificado de dois terços dos votos da Conferência Internacional do Trabalho e que, uma vez ratificadas pelas autoridades competentes de cada Estado-Membro, constituem-se como fontes formais de direito, podendo integrar o sistema jurídico dos países que a ela aderiram como norma positiva, capaz de gerar direitos subjetivos e obrigações correlatas. Além disso, as convenções internacionais do trabalho podem determinar a assunção de responsabilidades no plano internacional por parte do Estado que as ratifica. Isso porque, o ato de aderir a uma convenção coloca o país exposto a um controle de aplicação de suas disposições que contempla, dentre outras coisas, um procedimento de reclamações e queixas.

As recomendações, segundo ARNALDO SÜSSEKIND,

(...) constituem fonte material de direito, porquanto servem de inspiração e modelo para a atividade legislativa nacional, os atos administrativos de natureza regulamentar, os instrumentos da negociação coletiva e os laudos de arbitragem voluntária ou compulsória dos conflitos coletivos de interesse, neste último caso compreendidas as decisões dos tribunais do trabalho dotados de poder normativo. ${ }^{63}$

A doutrina do Direito Internacional Público tradicionalmente conceitua a recomendação como um instrumento não aberto a ratificação e que, portanto, não cria obrigações aos países participantes das conferências que a adotam. ${ }^{64}$ Todavia, no caso das recomendações da Organização Internacional do Trabalho, por força do disposto no art. 19, $\S 6^{\circ}$, da Constituição dessa organização, advém da adoção dos mencionados instrumentos, pelo menos, a obrigação formal de submetê-los, no prazo de até dezoito meses, à autoridade nacional com competência para legislar ou realizar as medidas referentes às matérias neles versadas. Tal autoridade, por sua vez, poderá transformar em lei um, alguns ou todos os dispositivos de determinada recomendação; adotar outras medidas em relação a eles; ou apenas tomar conhecimento sobre seu conteúdo, sem aprovar qualquer ato que lhe seja pertinente. No entanto, independentemente da atitude abraçada, cada país deverá informar, periodicamente, à Repartição Internacional do Trabalho sobre o estado de sua legislação e da observância do disposto na recomendação, indicando, se for o caso, as modificações que entende necessárias para efetivar internamente seu conteúdo. ${ }^{65}$

\footnotetext{
${ }^{63}$ ARNALDO SÜSSEKIND, op. cit. (Direito Internacional...), p. 181.

${ }^{64}$ ARNALDO SÜSSEKIND, op. cit. (Direito Internacional...), p. 195

${ }^{65}$ ARNALDO SÜSSEKIND, op. cit. (Direito Internacional...), p. p. 195-196.
} 
Infere-se, pois, que as recomendações da Organização Internacional do Trabalho não estão restritas, meramente, ao papel de proposições destinadas à exortação de organismos internacionais ou governos nacionais no sentido de adotarem certas medidas nelas preconizadas. Embora sua criação não represente aos Estados-Membros da OIT uma obrigação material de observância de seus pressupostos, como decorreria, por exemplo, de uma convenção internacional do trabalho devidamente ratificada e incorporada às suas respectivas ordens jurídicas nacionais, certo é que a sistemática de controle exercido em relação ao cumprimento de seu conteúdo (embora inferior ao adotado em relação às convenções) tem se revelado um mecanismo efetivo para a concretização de seus preceitos.

Como regra, no âmbito da Organização Internacional do Trabalho, as recomendações destinam-se a tratar de questões que, naquele momento, não se prestariam a serem tratadas por uma convenção (art. 19, § $1^{\circ}$, da Constituição da OIT). Entretanto, a Conferência Internacional do Trabalho vem aprovando, nos últimos anos, convenções com os princípios e regras atinentes à matéria versada, e utilizando recomendações regulamentares para lhes complementar. Salienta ARNALDO SÜSSEKIND que:

(...) esse critério, sem dúvida elogiável, permite a universalização de princípios socialtrabalhistas de relevo, porque propicia a quase duzentos países que regulamentem a aplicação dos mesmos, com atendimento ao respectivo nível de desenvolvimento socioeconômico, em conformidade com seus sistemas jurídicos e considerando as peculiaridades nacionais ou regionais. ${ }^{66}$

Além desse escopo regulamentar, atualmente a Conferência Internacional do Trabalho vem, igualmente, utilizando recomendações para disciplinar um tema sobre o qual o direito comparado ainda não vislumbre soluções largamente aceitas e para enunciar regras ainda avançadas para um grande número de Estados-Membros, mas cuja universalização a Conferência deseja promover. ${ }^{67}$

No que tange aos protocolos, estes podem ser definidos como instrumentos que modificam parcialmente as convenções, em razão da necessidade de se revisar algumas de suas disposições. ${ }^{68}$ Embora não haja previsão expressa na Constituição da OIT, grande parte das convenções aprovadas contém um regramento sobre a revisão de seus

\footnotetext{
${ }^{66}$ Op. cit., p. 197.

${ }^{67}$ ARNALDO SÜSSEKIND, op. cit. (Direito Internacional...), p. 197.

${ }^{68}$ Fonte: http://www.ilo.org/public/libdoc/ILO-Thesaurus. Acesso em 4/09/2008. Em igual sentido, LUCIANE CARDOSO BARZOTTO, op. cit., p. 87.
} 
respectivos conteúdos. Em regra, os protocolos estão abertos à ratificação pelos países que já aderiram à convenção original. Tais Estados poderão, contudo, não ratificar a norma revisora, o que implicará para eles a permanência em vigor do texto não modificado da convenção em sua ordem jurídica.

As declarações são atos de caráter solene, aprovados na Conferência Internacional do Trabalho, mas que não encontram previsão expressa na Constituição da OIT. Normalmente, destinam-se a confirmar ou reformular normas de direito costumeiro, enunciar princípios gerais de direito ou, por vezes, interpretar normas e princípios jurídicos contidos na constituição e em outros instrumentos. ${ }^{69}$ As principais declarações adotadas no âmbito da Organização Internacional do Trabalho foram, incontestavelmente, a Declaração sobre os Objetivos e Propósitos da OIT (Declaração da Filadélfia de 1944) e a Declaração da OIT relativa aos Princípios e Direitos Fundamentais no Trabalho de 1998.

As resoluções, a exemplo das declarações e protocolos, também são atos formais adotados na Conferência que não possuem disciplina expressa na Constituição da OIT. São aprovadas por maioria simples, em discussão única e dizem respeito, quase sempre, a questões não incluídas na ordem do dia da Conferência. Não geram obrigações para os Estados-Membros e servem, normalmente, para orientar a ação da própria OIT no que tange a assuntos internos. ${ }^{70}$

Acerca das orientações, informa LuCIANE CARDoso BARZOTTO que estas correspondem a observações, comentários e estudos remetidos diretamente aos governos pelo Diretor-Geral do Bureau Internacional do Trabalho. Segundo a autora:

As observações são utilizadas para casos mais graves de descumprimento de obrigações internacionais e são publicadas no informe da Comissão de Experts na Aplicação de Convenções e Recomendações (CECR). Os comentários e estudos são opiniões da repartição internacional do trabalho que esclarecem os Estados antes da adoção de norma internacional. $^{71}$

\footnotetext{
${ }^{69}$ LUCIANE CARDOSO BARZOTTO, op. cit., p. 87.

${ }^{70}$ ARNALDO SÜSSEKIND, op. cit. (Direito Internacional...), p. 180 e http://www.ilo.org/public/libdoc/ILOThesaurus. Acesso em 4/09/2008.

${ }^{71}$ Op. cit., p. p. 87-88.
} 
Por fim, o trabalho dos órgãos de supervisão e os documentos autorizados podem ser identificados como fontes doutrinárias e jurisprudenciais da Organização Internacional do Trabalho. ${ }^{72}$

\subsection{Atividade de Cooperação Técnica}

A semente da atividade de cooperação técnica realizada pela Organização Internacional do Trabalho já estava plantada na Parte XIII do Tratado de Versalhes em um dispositivo que hoje corresponde ao art. $10, \S 2^{\circ}$, alínea $b$, da Constituição da OIT. Tal norma dispõe que o Bureau Internacional do Trabalho, de acordo com as diretrizes que possa receber do Conselho de Administração, “fornecerá, na medida de seus recursos, aos Governos que o pedirem, todo o auxílio adequado à elaboração de leis, consoante as decisões da Conferência, e, também, ao aperfeiçoamento da prática administrativa e do sistema de inspeção".

Como se pode depreender, a atividade de cooperação no seio da Organização surgiu restrita ao escopo de complementar a sua atividade normativa e de tornar efetiva a aplicação de seus instrumentos. Tal função, no entanto, pôde ser alargada após a Declaração da Filadélfia de 1944, que modificou os objetivos da Organização Internacional do Trabalho, atribuindo-lhe amplo mandato para cooperar com os países membros, no intuito de promover-lhes o progresso econômico e social. No entanto, foi somente a partir de 1950, quando a Organização das Nações Unidas aprovou um programa de assistência técnica abrangendo todas as suas agências especializadas, que houve um substancial incremento dessa atividade pela Organização Internacional do Trabalho. Finalmente, o passo decisivo foi dado em 1958, quando a ONU instituiu o Fundo Especial das Nações Unidas, gerido pelo PNUD - Programa das Nações Unidas para o Desenvolvimento. Atualmente, também o Banco Mundial financia alguns projetos realizados pela Organização Internacional do Trabalho. ${ }^{73}$

Esclarece ARNALDO SÜSSEKIND que:

(...) a cooperação técnica à disposição dos Estados-membros da OIT tem por meta a valorização e o respeito aos direitos humanos do trabalhador, a criação e o desenvolvimento de instituições sociais e a melhoria das condições de vida e de trabalho. Nessa tríplice

\footnotetext{
${ }^{72}$ LUCIANE CARDOSO BARZOTTO, op. cit., p. 88.

73 ARNALDO SÜSSEKIND, op. cit. (Direito Internacional...), p. p. 285-286.
} 
finalidade se inserem múltiplos e variados programas. A maior parte dos programas tem por objetivo o fomento ao emprego, à formação técnico-profissional, às relações profissionais, aos direitos sindicais, ao combate ao trabalho de crianças e às cooperativas. ${ }^{74}$

São exemplos contundentes de programas de cooperação técnica desenvolvidos pela OIT o PIACT - Programa Internacional para Melhorar as Condições de Trabalho e Meio Ambiente de Trabalho, o IPEC - Programa Internacional para Eliminação do Trabalho Infantil e o Programa Mundial de Emprego.

\subsection{Atividade de Investigação e Divulgação}

As investigações e estudos realizados pela Organização Internacional do Trabalho têm o escopo inicial de fornecer um suporte para suas atividades de produção de normas internacionais e de cooperação técnica, por meio da coleta e reunião de dados estatísticos, preparação de relatórios, análise de práticas e legislações nacionais, e de outras medidas necessárias a garantir o sucesso de mencionadas ações.

Além disso, servem também para difundir universalmente informações e conhecimentos relativos aos problemas sociais e econômicos, assim como, mecanismos de atuação para o enfrentamento de tais questões.

Para tanto, a Organização Internacional do Trabalho promove uma série de publicações, tais como, a Revista Internacional do Trabalho, com artigos sobre questões sociais e econômicas de interesse internacional; o Boletim Oficial, que traz informações sobre as atividades da Organização e reproduz textos adotados nas conferências e reuniões; a Série Legislativa, que reproduz os textos legais mais importantes dos países, em matéria social; o Anuário e o Boletim de Estatísticas do Trabalho, com dados sobre emprego, desemprego, jornada de trabalho, salários etc.; além de livros, revistas doutrinárias, guias informativos, manuais e outros materiais. ${ }^{75}$

\subsection{Atividade de Controle da Aplicação das Normas Internacionais}

A OIT foi a instituição que introduziu no Direito Internacional a prática de utilizar mecanismos e procedimentos de controle da aplicação das normas internacionais

\footnotetext{
${ }^{74}$ Op. cit. (Direito Internacional...), p. 288.

${ }^{75}$ Geraldo W. von Potobsky e HÉCtOR G. BARTOlOMEI DE la CRUZ, op. cit., p. 22.
} 
por ela criadas. Hoje, grande parte da eficácia de suas ações pode ser atribuída a esse sistema, o que acabou por influenciar diversos outros organismos internacionais a adotarem medidas semelhantes.

Algumas formas de supervisão da aplicação das convenções e recomendações foram estabelecidas ainda na versão original da Constituição da OIT, em 1919. Dentre elas, está a obrigação, que perdura até os dias atuais, dos Estados-Membros enviarem relatórios periódicos ao Diretor-Geral da Repartição Internacional do Trabalho, informando sobre a situação de suas respectivas legislações e práticas nacionais relativas às questões tratadas nas normas internacionais do trabalho.

O sistema, entretanto, foi sendo aprimorado com o tempo. Já em 1926, em razão do grande volume de relatórios a serem examinados, foi criada uma Comissão de Peritos na Aplicação das Convenções e Recomendações, integrada por personalidades de reconhecida capacidade técnica, designadas pelo Conselho de Administração por proposta do Diretor-Geral do Bureau Internacional do Trabalho. Para manter certo grau de independência e imparcialidade, essas pessoas não representam governos. ${ }^{76}$

A partir do mesmo ano, a Conferência passou a designar, em todas as suas reuniões anuais, uma Comissão de Aplicação das Convenções e Recomendações de caráter tripartite. Tal comissão recebe os informes contendo a análise realizada pela Comissão de Peritos e convida os governos interessados a prestar esclarecimentos, escritos ou verbais, sobre as questões neles suscitadas. Após esse procedimento, a Comissão tripartida elabora um relatório contendo suas conclusões e o apresenta em sessão plenária da Conferência. Desde 1957, a citada comissão decidiu dar ampla divulgação, em seu informe geral, aos casos em que os governos parecem encontrar graves dificuldades no cumprimento de algumas de suas obrigações derivadas da Constituição da OIT ou das convenções ratificadas. ${ }^{77}$

Acerca da divulgação dos casos mais expressivos de descumprimento, assevera WALKÜRE LOPES RIBEIRO DA SILVA que "tais medidas não deixam de surtir alguns efeitos, incomodando os países publicamente arrolados. Entretanto, representam sanções mais morais do que jurídicas, pois deve ser respeitada a soberania nacional". ${ }^{78}$

A par desse mecanismo geral de controle, a Organização Internacional do Trabalho dispõe, ainda, de dois procedimentos especiais: a reclamação e a queixa.

\footnotetext{
${ }^{76}$ WAGNER D. GIGLIO, op. cit., p. 53.

${ }^{77}$ NicOlas VAlTiCOS, op. cit., p. p. 506-507.

${ }^{78}$ Op. cit., p. 116.
} 
O primeiro encontra sua disciplina nos arts. 24 e 25 da Constituição da OIT, que prevêem, em suma, a possibilidade de organizações profissionais de empregados ou de empregadores dirigirem ao Bureau Internacional do Trabalho uma reclamação contra determinado Estado-Membro que não tenha assegurado satisfatoriamente o cumprimento de alguma convenção por ele ratificada. Este órgão, por sua vez, transmite dita reclamação ao Conselho de Administração, que a examinará e dará oportunidade ao Estado manifestarse sobre seus termos. Caso o país reclamado deixe de responder ou apresente uma explicação insatisfatória, o Conselho de Administração tornará pública a reclamação como forma de sanção moral.

O procedimento de queixa é regrado pelo contido nos arts. 26 a 34 da Constituição da OIT. É cabível, também, na hipótese de não cumprimento por um EstadoMembro de alguma convenção por ele ratificada. Sua instauração, porém, somente ocorre por: iniciativa de outro Estado que igualmente tenha ratificado a mesma convenção; ex officio, pelo Conselho de Administração; ou por iniciativa de qualquer delegação na Conferência.

De maneira análoga aos trâmites da reclamação, a queixa é transmitida ao Conselho de Administração, que pode solicitar informações ao governo visado pela queixa. Caso a resposta seja insatisfatória ou simplesmente não ocorra, o Conselho poderá, nesse procedimento, constituir uma comissão de inquérito para análise da queixa e apresentação de parecer. Tal comissão poderá solicitar de quaisquer Estados-Membros as informações que reputar necessárias para a elucidação do caso e, após um exame aprofundado, deverá redigir um relatório do qual constarão não só suas verificações sobre todos os pontos que permitam bem medir o valor da contestação, como também as medidas que recomenda para dar satisfação ao Governo queixoso e os prazos, dentro dos quais, as medidas devem ser postas em execução.

Cabe ao Diretor-Geral do Bureau Internacional do Trabalho comunicar o relatório da comissão ao Conselho de Administração e a cada governo interessado, bem como, providenciar a sua publicação. No prazo de três meses, cada um dos Estados interessados deverá comunicar, por sua vez, ao Diretor-Geral se aceitam, ou não, os termos das recomendações contidas no relatório. Na hipótese negativa, poderá requerer que a divergência seja levada à Corte Internacional de Justiça, que irá decidi-la de maneira inapelável. 
No caso de um Estado não dar cumprimento, no prazo assinalado, às recomendações previstas no relatório da comissão de inquérito, porventura aceitas, ou à decisão da Corte Internacional de Justiça, poderá o Conselho de Administração solicitar à Conferência a ação que estime conveniente e oportuna para assegurar a sua respectiva execução. O governo infrator poderá, no entanto, informar, a qualquer momento, ao Conselho de Administração, que adotou as medidas necessárias ao cumprimento das referidas recomendações e requerer a designação de uma nova comissão de inquérito para averiguar a procedência de suas alegações. Constatado que houve realmente a adequação do Estado, deverá o Conselho recomendar que cessem as medidas adotadas pela Conferência.

Assinala Wagner D. Giglio que "diante da particular importância do princípio da liberdade sindical, a OIT entrou em entendimento com a ONU e criou, em 1950, um procedimento especial para a solução dos problemas emergentes da adoção desse princípio". ${ }^{79}$ Os órgãos encarregados desse controle são o Comitê de Liberdade Sindical e a Comissão de Investigação e Conciliação em matéria de liberdade sindical.

O Comitê de Liberdade Sindical é designado pelo Conselho de Administração e é composto por nove membros, sendo três representantes governamentais, três dos trabalhadores e três dos empregadores. Originalmente, foi idealizado como órgão que realizaria apenas um exame preliminar dos assuntos que lhe seriam submetidos, uma vez que o exame mais aprofundado das queixas deveria ser realizado pela Comissão de Investigação e Conciliação. Todavia, como bem explica WAGNER D. GIGLIO, a atuação deste último estava condicionada à anuência expressa dos governos, o que, de fato, não aconteceu, determinando, assim, a sua ineficácia prática. ${ }^{80}$

O Comitê passou, então, a reunir as queixas e respostas dos governos denunciados que, complementadas por outras informações, dão ensejo a um relatório final, encaminhado ao Conselho de Administração. Com base nesse relatório, o Conselho faz recomendações aos governos infratores, sugerindo-lhes medidas legislativas ou práticas para correção dos problemas.

A Comissão de Investigação e Conciliação é composta por personalidades designadas pelo Diretor-Geral do Bureau Internacional do Trabalho, escolhidas por sua especial competência e chamados a exercer suas funções com a mais completa liberdade. Foi o órgão formalmente criado em 1950 para desempenhar a tarefa de examinar as

\footnotetext{
${ }^{79}$ Op. cit., p. 56.

${ }^{80}$ Op. cit., p. 57.
} 
queixas e recomendar medidas aos governos. Entretanto, como já explicado, sua competência foi suplantada, na prática, pelo Comitê de Liberdade Sindical. 


\section{CAPÍTULO II - AS CONVENÇÕES INTERNACIONAIS DO TRABALHO}

\section{DENOMINAÇÃo}

Não há, na prática do Direito Internacional Público, uma precisão metodológica para a utilização das expressões convenção, tratado, declaração, pacto e acordo, sendo, muitas vezes, tais termos empregados como sinônimos. ${ }^{81}$ Todavia, há atualmente certa tendência em adotar a expressão convenções para designar os tratados multilaterais abertos criados em conferências realizadas na esfera de organismos internacionais ou regionais de direito público. ${ }^{82}$

Nesse sentido, parece adequada a denominação adotada pela Organização Internacional do Trabalho para designar os seus principais instrumentos normativos - as Convenções Internacionais do Trabalho. Com efeito, como se observará mais adiante, quando da análise na natureza jurídica das convenções, tais instrumentos podem ser enquadrados na definição, em sentido amplo, de tratados internacionais. Ademais, perfazem-se, ainda que com características peculiares, por meio de um processo de elaboração ocorrido no âmbito de uma conferência geral de uma organização internacional. ${ }^{83}$ Por fim, estão, em regra, abertas à ratificação pelos Estados-Membros da Organização.

Ainda quanto ao aspecto terminológico, destaca AMÉRICo Plá Rodriguez, que até 1946 a Organização Internacional do Trabalho utilizou-se da expressão "projeto de convenção" para indicar uma convenção que havia sido aprovada por sua Conferência, mas

\footnotetext{
${ }^{81}$ Nesse sentido, NGuYen QuOC Dinh, PATRICK DAILliER e Alain PELlET afirmam que:

"A variedade do vocabulário na prática é impressionante: tratado, convenção, protocolo, declaração, carta, pacto, estatuto, acordo, modus vivendi, troca de notas, troca de cartas, memorando de acordo, processo-verbal aprovado, concordata e, mesmo em certos casos, código de conduta.

Verificou-se que o termo 'concordata' se reserva aos acordos concluídos com a Santa Sé. Excluindo este caso, não existem critérios certos que permitam determinar rigorosamente o campo de aplicação de cada denominação. Pode acontecer que em função do objecto e da forma de certos acordos, os seus autores optem por uma ou outra destas denominações. Mas, na prática, a escolha depende de simples considerações de oportunidade. (...)

Todos estes termos têm a mesma significação jurídica em direito internacional (mas não forçosamente em direito constitucional); a prática revela que os termos 'tratado', 'convenção', 'acordo' são intermutáveis e são muitas vezes adoptados como termos genéricos”. In Droit International Public, trad. port. de Vitor Marques Coelho, Direito Internacional Público, $2^{a}$ ed., Lisboa, Fundação Calouste Gulbenkian, 2003, p. 123. De igual modo, confira-se Guido Fernando Silva SoARes, Curso de Direito Internacional Público, Vol. 1, São Paulo, Atlas, 2002, p. p. 60-61.

${ }^{82}$ ARNALDO SÜSSEKIND, op. cit. (Convenções...), p. 30.

${ }^{83}$ A esse respeito, confira-se o tópico 2 deste Capítulo.
} 
que não teria sido ratificada por nenhum país. Tal se justificaria porque, no Direito Internacional, considera-se a ratificação como o ato que dá validade e eficácia jurídica a um tratado. No entanto, a reforma à Constituição da OIT, ocorrida em 1946 substituiu a utilização, para tal situação, do termo "projeto de convenção" por "convenção". Segundo explicação emanada do próprio Bureau Internacional do Trabalho, dois foram os motivos que conduziram a Organização Internacional do Trabalho à citada decisão: primeiro, porque a expressão "projeto de convenção" não seria adotada em nenhuma outra organização internacional para designar uma norma já aprovada; segundo, porque essa expressão estaria historicamente associada ao desejo de marcar o caráter facultativo das disposições adotadas pela Conferência, o que teria conduzido a certos equívocos, no passado, quanto ao caráter das obrigações que resultam das ratificações das convenções. ${ }^{84}$

Atualmente, reserva-se o termo "projeto de convenção" somente ao texto que não tiver obtido, ainda, sua aprovação final na Conferência (art. 21 da Constituição da OIT).

\section{Características Gerais}

\subsection{Conteúdo}

As convenções internacionais do trabalho têm um conteúdo específico, delimitado pelos próprios objetivos e competências que possui a Organização Internacional do Trabalho. ${ }^{85}$ São, dessa forma, instrumentos internacionais especializados que não podem versar sobre toda e qualquer matéria, mas somente sobre assuntos relacionados à regulação das relações de trabalho e as ações que permitam o alcance da paz universal e bem-estar da humanidade, por meio da justiça social.

Não se trata, porém, de um conteúdo pequeno, pois abarca não apenas a proteção dos trabalhadores propriamente ditos, mas o conjunto dos seres humanos nas suas relações com o trabalho. Além do mais, dentro de seu campo de ação, a Organização Internacional do Trabalho goza de plena liberdade para o estabelecimento de suas normas. Nesse sentido pode criar convenções versando sobre direitos de aplicação imediata e regulatória, como por exemplo, as Convenções Internacionais que prescrevem a fixação de uma idade mínima para o trabalho (n. 138), a proibição de trabalho forçado (n. 29 e n.

${ }^{84}$ Op. cit., p. p. $227-229$.

${ }^{85}$ Sobre os objetivos da Organização Internacional do Trabalho, confira-se o item 3 do Capítulo I. 
105), a liberdade de organização sindical (n. 87), dentre outras; e, ao mesmo tempo, convenções que constituam verdadeiros programas de ação aos governos que as ratificam, tais como, as Convenções Internacionais de n. 117 (sobre objetivos e normas básicas da política social) e a de n. 122 (referente à política de emprego).

Sobreleva notar também que o conteúdo das convenções internacionais do trabalho é marcado pelas características da universalidade e da flexibilidade de suas disposições.

A nota da universalidade decorre do próprio caráter da Organização Internacional do Trabalho, que atualmente congrega quase a totalidade dos países do mundo e tem sua atuação direcionada não apenas a criar uma legislação internacional do trabalho, mas também a assegurar o bem-estar e o progresso, no campo social, de toda a humanidade. ${ }^{86}$ Por tal motivo, seus instrumentos normativos são produzidos em uma conferência de índole universal, acabam refletindo as necessidades e anseios da generalidade dos Estados-Membros e, em igual medida, propõem-se a lançar seus efeitos sobre todos eles.

Ocorre, no entanto, que o caráter universal das convenções internacionais do trabalho faz com que elas tenham como destinatários países com graus de desenvolvimento sócio-econômico e com sistemas jurídicos muito distintos uns dos outros. Isso, inevitavelmente, implica a necessidade da adoção de fórmulas de flexibilidade de seu conteúdo para que se garantam a seus dispositivos um mínimo de eficácia e não os transformem em simples metas utópicas. Por outro lado, tais medidas devem ser muito bem equilibradas, de modo a não retirar das convenções seu poder de influenciar as transformações necessárias ao progresso social ou descaracterizá-las enquanto normas jurídicas. De acordo com NiCOLAS VAlTiCOS, a flexibilidade exigida para as normas internacionais do trabalho "pode se manifestar em três planos diferentes: quanto ao nível de proteção previsto pelas normas; quanto à formulação mais ou menos precisa das normas e quanto às distintas modalidades de aplicação autorizadas pelas normas". ${ }^{87}$

\footnotetext{
${ }^{86}$ A índole universal dos fins perseguidos pela Organização Internacional do Trabalho pode ser evidenciada no item V da Declaração da Filadélfia de 1944, que proclama: "A Conferência afirma que os princípios contidos na presente Declaração convêm integralmente a todos os povos e que sua aplicação progressiva, tanto àqueles que são ainda dependentes, como aos que já se podem governar a si próprios, interessa o conjunto do mundo civilizado, embora se deva levar em conta, nas variedades dessa aplicação, o grau de desenvolvimento econômico e social atingido por cada um".

${ }^{87}$ La Protection dês Droits de l'Homme par l'Organization Internacionale du Travail in Revue dês Droit de l’Homme, Vol. IV, n. 4, Paris, 1971, p. 749-753, apud ARNALDO SÜSSEKIND, op. cit., p. 185.
} 


\subsection{Forma}

As convenções internacionais do trabalho seguem, formalmente, um modelo padrão, composto por três partes muito bem identificadas e descritas por AMÉRICO PLÁ RODRIGUEZ: o preâmbulo, a parte dispositiva e as cláusulas finais. ${ }^{88}$

O preâmbulo geralmente contém, em seu primeiro parágrafo, a data, o local e o número da sessão da Conferência Internacional do Trabalho que adotou a convenção. Os seus três parágrafos seguintes referem-se, em regra, à colocação que o assunto teve na ordem do dia, a natureza do documento e a forma pela qual poderá ser designada.

A parte dispositiva, por sua vez, se expressa por meio de artigos e pode ser subdividida em três grupos. O primeiro deles compreende as disposições que estabelecem a esfera funcional de aplicação da convenção, bem como, a descrição de alguns conceitos básicos. O segundo grupo é o que estabelece propriamente o conteúdo de fundo, regulamentando o tema. Por fim, há um terceiro grupo de artigos que compreende as disposições sobre modalidades especiais de aplicação da convenção a certos países e que correspondem, portanto, a fórmulas de flexibilidade das convenções, conforme exposto em tópico anterior.

Por derradeiro, as cláusulas finais podem ser identificadas como o núcleo de oito a dez artigos, verificado na maioria das convenções, que possui o escopo de regulamentar: a forma de comunicação das ratificações, a data de entrada em vigor, a duração da vigência, as declarações sobre a aplicação das regras, a possibilidade e a forma de denúncia, a oportunidade e os efeitos da revisão, e os textos autênticos da convenção.

\subsection{Eficácia jurídica}

As convenções da OIT são instrumentos normativos internacionais que se distinguem dos demais, não apenas pelo seu conteúdo ou pelo seu peculiar processo de elaboração, como será demonstrado a seguir, mas também por alguns aspectos de sua eficácia jurídica.

\footnotetext{
${ }^{88}$ Op. cit., p. p. 231-233.
} 
Inicialmente, cumpre esclarecer que, desde os primórdios da Organização Internacional do Trabalho, seus idealizadores já haviam se dado conta de que o alcance dos seus objetivos não poderia ocorrer por meio da adoção de normas internacionais tradicionais, reguladoras apenas das relações entre Estados. Isso porque o campo de atuação do Direito do Trabalho sempre foi o das relações jurídicas entre particulares, desenvolvidas no âmbito interno de cada país.

Desse modo, mostrava-se necessário, portanto, não a criação de normas internacionais nos moldes do que se conhecia até então, mas de instrumentos novos na prática do Direito Internacional Público, que repercutissem na órbita jurídica interna de cada Estado, a fim de estabelecer uma regulamentação mínima e uniforme das relações de trabalho.

Apontam Geraldo W. von Potobsky e Héctor G. BARtolomei de la CRUZ que historicamente a intenção de algumas delegações que participaram da elaboração da Parte XIII do Tratado de Versalhes foi a de criar um poder legislativo internacional que tivesse faculdades para ditar normas obrigatórias per se, sem que fosse necessária a aprovação dos governos respectivos para a sua aplicação interna aos distintos EstadosMembros. Tal posição, que era defendida especialmente pela França e pela Itália, encontrou resistência por parte das demais delegações, que encaravam a proposta inviável, por representar uma agressão à soberania dos países, além de desconsiderar a disparidades de situações relativas aos diferentes níveis de desenvolvimento entre eles. ${ }^{89}$

Uma solução alternativa a anterior, apresentada pela delegação norteamericana, acabou prevalecendo. Rezava que a Conferência Internacional do Trabalho poderia dar ensejo a dois tipos de instrumentos: o primeiro, a recomendação, geraria, a cada Estado-Membro, apenas a obrigação de submetê-la às suas respectivas autoridades competentes para que estas adotassem medidas legislativas internas com o escopo de dar aplicação a suas disposições; o segundo, as convenções internacionais do trabalho, teriam uma maior eficácia, podendo integrar-se ao sistema jurídico de cada país, por meio de um ato de ratificação e, assim, regular as relações laborais desenvolvidas internamente.

Atualmente, a sistemática proposta pelos EUA, em 1919, integra, sem grandes alterações, a Constituição da OIT. Porém, é mister ressaltar que a eficácia jurídica das convenções internacionais do trabalho transcende à sua própria ratificação.

\footnotetext{
${ }^{89}$ Op. cit., p. 23.
} 
Com efeito, o mero fato de uma convenção ter sido adotada já cria aos Estados-Membros a obrigação de submetê-la, no prazo de um ano, a partir do encerramento da Conferência, à autoridade ou autoridades a quem competir o assunto, ao efeito de que lhe dêem forma de lei ou adotem outras medidas (art. 19, § $5^{\circ}$, alínea $b$, da Constituição da OIT). Gera, ainda, a obrigação das autoridades nacionais informarem ao Diretor-Geral do Bureau Internacional do Trabalho referida submissão (art. 19, § 5ª alínea $c$, da Constituição da OIT).$^{90}$

Tal obrigação impõe-se até aos Estados que não tenham participado da Conferência (como, por exemplo, aqueles que, antes da sua realização, ainda não eram membros da Organização Internacional do Trabalho) ou aos países cujos delegados tenham votado contra a adoção da convenção. Além disso, subsiste mesmo na hipótese em que já exista lei nacional dispondo sobre a matéria e em igual sentido ao da convenção adotada.

O objetivo da submissão, aponta NiCOLAS VALTiCOS, consiste em por as autoridades responsáveis pela elaboração das leis sociais em cada um dos EstadosMembros em condições de pronunciarem-se sobre o curso que devam dar às convenções e suscitar uma decisão sobre o tema. ${ }^{91}$ Não se trata, exatamente, de uma obrigação que tenha, como fim específico e imediato, a obtenção da ratificação desse instrumentos internacionais, não sendo, portanto, dirigida à autoridade ou às autoridades responsáveis pela ratificação dos tratados. Cuida-se, antes de qualquer coisa, de um mecanismo de provocação das autoridades com competência, em cada país, para a criação de leis sobre os mesmos assuntos tratados nas convenções aprovadas, com o intuito de que,

\footnotetext{
${ }^{90}$ A disposição contida no art. $19, \S 5^{\circ}, b$, devido à sua linguagem imprecisa e ambígua, foi objeto de significativas controvérsias quanto à sua interpretação e aplicação. Tal circunstância conduziu a Comissão de Questões Jurídicas e Normas Internacionais do Trabalho, vinculada ao Conselho de Administração da OIT, a produzir sucessivos "Memorandos sobre a Obrigação de Submeter as Convenções e Recomendações às Autoridades Competentes" com o escopo de orientar os governos no cumprimento das obrigações estabelecidas na Constituição, sendo o mais recente adotado em 2005.

Mencionado documento tem esteio em pronunciamentos da Comissão de Peritos na Aplicação de Convenções e Recomendações e reflete, no tocante à matéria, a posição oficial da Organização Internacional do Trabalho acerca dos pontos mais sensíveis a questionamentos entre seus membros. Dentre esses, podem ser destacados os fins e objetivos da submissão das convenções, a especificação da autoridade competente e o alcance da obrigação.

De acordo com o Memorando de 2005, a autoridade competente aludida pela regra prevista no art. $19, \S 5^{\circ}$, b, da Constituição da OIT é a autoridade nacional com competência legislativa definida pela Constituição de cada Estado-Membro. Os fins e objetivos são o fomento à adoção de medidas no plano nacional para a aplicação das convenções; o estímulo à ratificação desses instrumentos; e a difusão de seu conteúdo perante a opinião pública, por meio do debate em um órgão parlamentar. Quanto ao alcance da obrigação de submeter as convenções aprovadas, referido documento explicita que os governos têm plena liberdade no que diz respeito à formulação das propostas que devem ser remetidas juntamente com o texto das convenções ao órgão legislativo nacional, podendo inclusive deixar de propor a ratificação dos citados instrumentos.

Fonte: www.ilo.org. Acesso em 12/09/2008.

${ }^{91}$ Op. cit., p. 469.
} 
independentemente da ratificação da convenção, possam legislar em igual sentido sobre o tema ou adotar outras medidas para aplicação de seus preceitos.

Inobstante isso, certa parte da doutrina tende a associar a submissão à ratificação ${ }^{92}$, o que sempre suscitou confusão em torno da correta aplicação e alcance da regra prevista na Constituição da OIT.

Tal situação foi muito bem apreendida e devidamente esclarecida por Geraldo W. von Potobsky e Héctor G. BARTolomei de la CRUZ, para quem

(...) estas reglas novedosas en materia de derecho internacional causabam confusión en algunos países, por no distinguirse adecuadamente dos actos distintos: por una parte, la ratificación de un convenio, de caráter voluntario, por la autoridad que constitucionalmente está autorizada a efectuarla; por otra parte, la sumisión del convenio o de una recomendación a la autoridad competente, para darle aplicación interna por medio de una ley ou en otra forma. La adopción de estas medidas de aplicación es, por supuesto, también voluntária.

Puede ser que, en ciertos países, ambos actos sean realizados por la misma autoridad, pero muchas veces la autoridad que al ratificar un instrumento asume un compromisso internacional es distinta de aquella o aquelles que legislan para dar efectividad o cumplimento a una norma en el ordem interno. ${ }^{93}$

$\mathrm{Na}$ realidade, a submissão às autoridades competentes corresponde a uma eficácia peculiar das convenções internacionais do trabalho que, independentemente da sua ratificação, têm capacidade de gerar a produção de efeitos no sistema normativo de cada Estado-Membro da Organização Internacional do Trabalho, ainda que de maneira mediata.

Além da obrigação acima aludida, o simples fato da adoção de uma convenção sujeita o Estado, mesmo quando não a ratifique, a informar periodicamente ao Diretor-Geral do Bureau Internacional do Trabalho sobre a sua legislação e prática observada relativamente ao assunto de que trata a convenção, devendo precisar nessas informações até que ponto aplicou, ou pretende aplicar, dispositivos da convenção, por

\footnotetext{
92 Nesse sentindo, confira-se José FrancisCo REZEK, Direito dos Tratados, Rio de Janeiro, Forense, 1984, p. p. 165, WALKÜRE LOPES RIBEIRO DA SILVA, op. cit., p. 114 e WAGNER D. DE GIGLIO, op. cit., p. 46.

93 “(...) estas regras nebulosas em matéria de Direito Internacional causavam confusão em alguns países, por não se distinguir adequadamente dois atos distintos: por uma parte, a ratificação de uma convenção, de caráter voluntário, pela autoridade que constitucionalmente está autorizada a efetuá-la; por outra parte, a submissão da convenção ou de uma recomendação à autoridade competente, para lhe dar aplicação interna por meio de uma lei ou outra forma. A adoção destas medidas é, evidentemente, também voluntária.

Pode ser que, em certos países, ambos os atos sejam realizados pela mesma autoridade, porém muitas vezes a autoridade que, ao ratificar um instrumento, assume um compromisso internacional é distinta daquela ou daquelas que legislam para dar cumprimento a uma norma na ordem interna” (tradução livre). Op. cit., p. 64.
} 
intermédio de leis, por meios administrativos, por força de contratos coletivos, ou, ainda, por qualquer outro processo, expondo, outrossim, as dificuldades que impedem ou retardam a ratificação da convenção (art. 19, § 5, alínea $e$, da Constituição da OIT). Com base nesse preceptivo, ARNALDO SÜSSEKIND conclui que uma convenção internacional do trabalho não ratificada tem uma incontestável eficácia, constituindo-se em verdadeira fonte material de direito, ao inspirar a atividade legislativa nacional. ${ }^{94}$

Caso haja a ratificação, a eficácia jurídica da convenção torna-se, naturalmente, ainda mais expressiva, sujeitando o Estado, no plano internacional, a um maior grau de responsabilidade pela aplicação de suas disposições, que pode ser traduzido pela possibilidade de ser submetido a uma atividade mais rígida de controle, abarcando os procedimentos de representação e queixa, já tratados no capítulo anterior.

No plano interno, uma convenção ratificada obriga o Estado-Membro a tomar medidas concretas destinadas a garantir a efetivação de suas disposições. Mais importante do que isso, seus efeitos atingem propriamente a esfera das relações jurídicas laborais, gerando direitos e deveres aos seus sujeitos.

\section{Processo de Elaboração}

\subsection{Inscrição na Ordem do Dia da Conferência}

A primeira etapa para elaboração de uma convenção é a inscrição da questão que constituirá seu objeto na ordem do dia da Conferência Internacional do Trabalho.

Ordinariamente, compete ao Conselho de Administração organizar a pauta das sessões da Conferência, com base no encaminhamento, pelo Diretor-Geral do Bureau Internacional do Trabalho, de assuntos que lhe são apresentados pelos governos de quaisquer dos Membros, por qualquer organização representativa de empregados ou empregadores que venham a compor a delegação de um Estado-Membro na Conferência, ou, finalmente, por qualquer organização de Direito Internacional Público (art. 14, $\S 1^{\circ}$, da Constituição da OIT).

Geralmente, a remessa dos assuntos ao Conselho de Administração faz-se acompanhar também de um relatório do Diretor-Geral do Bureau Internacional do Trabalho, contendo uma breve exposição da legislação relacionada aos temas propostos,

\footnotetext{
${ }^{94}$ Op. cit. (Direito Internacional...), p. 181.
} 
em vigor nos diversos países membros, assim como, uma sucinta análise de sua efetiva aplicação. Afora esse informe, o Conselho de Administração antes de decidir sobre a inclusão de determinado assunto na pauta da sessão da Conferência Internacional do Trabalho, poderá submetê-la a uma conferência técnica preparatória, ou a qualquer outro procedimento análogo (art. $14, \S 2^{\circ}$, da Constituição da OIT).

Expõem Nicolas Valticos que os critérios seguidos pelo Conselho de Administração para a escolha das propostas que irão compor a ordem do dia são geralmente os da urgência, atualidade ou amadurecimento das questões, bem como, um desejo de equilíbrio no tratamento de questões que interessem a categorias distintas de trabalhadores ou de países. Demais disso, salienta o mesmo autor que a resolução do Conselho a respeito de colocar ou não na ordem do dia da Conferência determinada matéria deve, salvo votação unânime de seus membros em sentido contrário, ser tomada na reunião seguinte à sua apresentação, como forma de garantir que o órgão pronuncie-se com conhecimento de causa. ${ }^{95}$

Uma vez estabelecida a ordem do dia, existe, ainda, a possibilidade de cada Estado-Membro impugnar uma ou mais matérias, mediante petição dirigida ao DiretorGeral da Repartição Internacional do Trabalho, devidamente fundamentada. Tal documento é posto em deliberação na Conferência e, caso seja rejeitado por dois terços dos votos dos presentes, o assunto impugnado permanece em pauta na mesma sessão (art. 16, $\S \S 1^{\circ}$ e $2^{\circ}$, da Constituição da OIT).

Há, finalmente, a possibilidade de a própria Conferência Internacional determinar a inclusão de um assunto na pauta da sessão seguinte, mediante decisão tomada pela maioria de dois terços de seus membros (art. 16, § $3^{\circ}$, da Constituição da OIT).

\subsection{Preparação}

Após a decisão do Conselho de Administração quanto à ordem do dia da Conferência, o Bureau Internacional do Trabalho elaborará, com a maior antecedência possível, um informe contendo: “a) um sumário da legislação e da prática nos diversos países, no que respeita ao assunto em estudo; b) os princípios que informam essa matéria; c) as regulamentações nacionais, divididas em grupos, mediante as quais se dá

\footnotetext{
${ }^{95}$ Op. cit., p. p. 220-221.
} 
cumprimento aos princípios". 96 Tal informe é remetido a cada um dos Estados-Membros da Organização Internacional do Trabalho, juntamente com um questionário, que deverá ser respondido de maneira fundamentada e devolvido ao Bureau, normalmente, oito meses antes do início da Conferência.

Em seguida aos mencionados trâmites, a Repartição Internacional do Trabalho, podendo valer-se de um comitê de técnicos, redige um novo relatório, fixando, com base nas respostas recebidas, os principais pontos que devem ser considerados pela Conferência. $^{97}$ Por sua vez, esse relatório é, em regra, encaminhado aos governos com quatro meses de antecedência da data de abertura da sessão da Conferência Internacional do Trabalho e serve, geralmente, como base para a primeira discussão da matéria.

\subsection{Discussão}

Em regra, a Conferência Internacional do Trabalho adota, desde 1926, um sistema de dupla discussão de seus instrumentos, que permite uma formação mais acurada e minuciosa de seus respectivos textos. Entretanto, pode acontecer de, eventualmente, a Conferência optar por um procedimento simplificado de discussão única.

No sistema padrão de dupla discussão, terminados os trabalhos preparatórios descritos no tópico anterior, as questões são postas em exame pela primeira vez na Conferência, que, em geral, constitui uma comissão técnica especial para cada assunto da ordem do dia, com composição tripartite. No curso da primeira discussão, a referida comissão técnica e, posteriormente, a própria Conferência, em sessão plenária, decidem, inicialmente, se a questão é suscetível ou não de ser objeto de uma convenção internacional do trabalho. Em caso positivo, a Conferência resolve, em seguida, se a questão será incluída na ordem do dia da sessão seguinte ou se requisitará ao Conselho de Administração a sua inclusão na pauta de uma reunião posterior.

Com fulcro nos resultados alcançados nessa primeira discussão e nas respostas dos Estados-Membros ao questionário preparatório, o Bureau Internacional do Trabalho confecciona um novo relatório, bem como, um ou vários projetos de convenção, sobre os quais cada país deve manifestar-se no prazo de três meses contados do seu recebimento, apresentando, inclusive, as emendas e observações que entender pertinentes. De posse das respostas dos governos, a Repartição realiza um informativo final,

\footnotetext{
${ }^{96}$ WAGNER D. GIGLIO, op. cit., p. 39.

97 ARNALDO SÜSSEKIND, op. cit. (Direito Internacional...), p. 187.
} 
incorporando, se for o caso, as propostas de emendas apresentadas aos projetos de instrumentos, e o encaminha, novamente, aos Estados-Membros com antecedência de três meses do início da nova Conferência.

No curso da segunda discussão, as questões são, geralmente, examinadas também no âmbito de comissões técnicas tripartites. Em primeiro lugar é decidido, normalmente, se os projetos elaborados pela Repartição Internacional do Trabalho podem servir de base para a discussão. Independentemente da adoção ou não dos projetos encaminhados pela Repartição, cada comissão técnica deverá apresentar ao final de seus trabalhos, um informativo acompanhado do texto da convenção. Em sessão plenária, a Conferência examina tais documentos e discute, artigo por artigo, o conteúdo do projeto, antes de decidir se o aprova.

Em havendo a aprovação do projeto apresentado pela comissão técnica, este é levado ao Comitê de Redação da Conferência Internacional do Trabalho para a preparação do texto definitivo, que será submetido ao plenário da Conferência para a sua adoção final.

Em caso de urgência especial ou quando existam outras circunstâncias particulares, o Conselho de Administração pode decidir que a questão seja submetida a um procedimento de discussão simples no âmbito da Conferência Internacional do Trabalho antes de sua aprovação. Essa decisão deve ser tomada pela maioria de três quintos dos votos emitidos pelo Conselho. Em geral, são verificadas também nesse trâmite algumas etapas preparatórias. De fato, a Repartição Internacional do Trabalho também elabora, nesse procedimento, um informativo e um questionário, destinados aos governos. Todavia, uma vez obtidas as respostas aos questionários, a Repartição já elabora o projeto de convenção, que é submetida à análise da Conferência em uma única e definitiva discussão, antes de sua aprovação.

\subsection{Aprovação do Projeto de Convenção}

A aprovação de uma convenção internacional do trabalho é alcançada com o voto de dois terços dos delegados presentes à Conferência Internacional do Trabalho (art. 19, $\S 2^{\circ}$, da Constituição da OIT). Releva notar que, na sistemática tripartite da Organização Internacional do Trabalho, cada representante tem liberdade de votar como 
entender, independentemente da posição assumida pelos outros membros de sua delegação, e seu voto é computado individualmente.

Outra característica marcante do processo de elaboração das convenções da Organização Internacional do Trabalho que deflui de seu sistema de votação é a possibilidade de aprovação por maioria, o que, como salienta WAGNER D. GIGLIO, destoa dos demais acordos internacionais que necessitam da anuência de todas as partes contratantes. $^{98}$

Tendo sido aprovada em sessão plenária, a convenção é autenticada pelo Presidente da Conferência e pelo Diretor-Geral do Bureau Internacional do Trabalho, em duas vias. Uma delas é depositada nos arquivos do citado Bureau e a outra é enviada ao Secretário-Geral da Organização das Nações Unidas.

Findos esses trâmites, o Diretor-Geral remete, em seguida, uma cópia certificada da convenção a cada um dos Estados-Membros. Referido envio, segundo AMÉRICO PlÁ RoDRIGUEZ, não tem, contudo, o valor de uma notificação, a partir da qual começariam a fluir os prazos para o cumprimento pelos Estados-Membros das obrigações decorrentes da simples adoção de uma convenção internacional, uma vez que estes se iniciariam a partir do encerramento da Conferência que a aprovou. Portanto, teria tal remessa apenas a finalidade de fornecer a cada país o texto autêntico, com o propósito de aclarar quaisquer eventuais dúvidas sobre seus termos. ${ }^{99}$

Finalmente, cabe registrar que os textos autênticos das convenções são redigidos nos idiomas inglês e francês. Todavia, poderão ser objeto de tradução oficial, aprovada pelo Diretor-Geral da Repartição, para o idioma dos países que a solicitarem.

\section{NATUREZA JURÍDICA}

Ao longo da história, a natureza jurídica das Convenções Internacionais do Trabalho tem sido objeto de grande dissenso doutrinário. A maioria dos autores parte do pressuposto de que as convenções se enquadrariam numa definição ampla de tratado, controvertendo, porém, quanto a sua colocação em uma ou outra de suas categorias, tradicionalmente identificadas pela teoria do Direito Internacional Público. Outros, porém, sustentam que citados instrumentos, em razão de suas características peculiares, seriam figuras totalmente originais, impossíveis de serem equiparadas aos tratados.

\footnotetext{
${ }^{98}$ Op. cit., p. 41.

${ }^{99}$ Op. cit., p. 256.
} 


\subsection{As Convenções Internacionais do Trabalho como Tratados}

\subsection{Definição e Classificação dos Tratados em Geral}

Segundo Nguyen Q. Dinh, Patrick Daillier e Alain Pellet, o termo tratado designa "qualquer acordo concluído entre dois ou mais sujeitos de direito internacional, destinado a produzir efeitos de direito e regulado pelo direito internacional". ${ }^{100}$ Para os mencionados juristas, os elementos que compõem esse conceito já se encontravam solidamente estabelecidos na ciência e prática jurídicas; todavia, teria ele sido complementado, de maneira feliz, pela Convenção de Viena sobre o Direito dos Tratados, de 1969, que apresenta uma definição escrita para o instituto ${ }^{101}$, nos seguintes termos:

A expressão 'tratado' designa um acordo internacional, concluído por escrito entre Estados e regido pelo direito internacional, quer esteja consignado num instrumento único, quer em dois ou vários instrumentos conexos, e qualquer que seja a sua denominação particular. (Art. $2^{\circ}, \mathrm{I}, a$ ).

O enunciado supra transcrito excluiu, em princípio, os instrumentos normativos elaborados na esfera das organizações internacionais ou celebrados entre estas e Estados. Tal equívoco, no entanto, foi corrigido por meio da Convenção de Viena de 1986, que deixou claro que as organizações internacionais, como sujeitos do Direito Internacional Público, detêm igualmente o poder para celebrar tratados.

Atualmente, portanto, não pairam dúvidas de que os instrumentos jurídicos, criados no seio de organizações internacionais e que se destinam a produzir efeitos regulados pelo Direito Internacional, podem ser enquadrados na definição ampla de tratados.

Os tratados internacionais costumam, em geral, ser classificados segundo dois métodos: o material, que leva em conta os seus aspectos intrínsecos, ou seja, o seu conteúdo ou a sua função jurídica; e o formal, que se atêm a suas variáveis extrínsecas.

De acordo com o primeiro método classificatório (fundado em critérios materiais), é possível distinguir-se os tratados entre normativos e constitutivos de

\footnotetext{
${ }^{100}$ Op. cit., p. 120.

${ }^{101}$ Op. cit., p. p. $120-122$.
} 
organizações internacionais. Além dessa distinção, é tradicional também na doutrina internacionalista a oposição entre tratados-leis e tratados-contratos, sendo esta o cerne das maiores polêmicas teóricas acerca da definição da natureza jurídica das convenções internacionais do trabalho e que, portanto, será vista com melhor apuro nos itens subseqüentes.

Pelo método formal, adotam-se usualmente: a) o critério que classifica os tratados em função da qualidade das partes, diferenciando-os entre tratados concluídos entre Estados, tratados concluídos entre Estados e organizações internacionais, e tratados celebrados por organizações internacionais; b) o critério que considera o número de partes, classificando os tratados como bilaterais ou multilaterais; c) o critério relativo à possibilidade de adesão de outros sujeitos, além daqueles que celebraram originalmente os tratados, considerando-os como abertos ou fechados; d) o critério que leva em conta apenas a forma pela qual os tratados são celebrados, distinguindo-os como de forma solene e de forma simplificada.

Com base em tais categorias e por tudo o que já foi exposto quantos às características das convenções internacionais do trabalho e ao processo de sua elaboração, é possível, sem maiores esforços, considerar tais instrumentos como tratados de caráter normativo (em contraposição a tratados constitutivos de organizações internacionais), multilaterais, concluídos no seio de uma organização internacional, abertos e solenes.

Não é tão óbvia, porém, a classificação das convenções fundada no critério material da natureza de suas disposições. Tal questão refere-se justamente à distinção entre tratados-leis e tratados-contratos e, como já afirmado anteriormente, é a que suscita maior divergência doutrinária.

Cumpre, antes do desenvolvimento do referido tema, expressar que, para um considerável número de autores internacionalistas, referida distinção não teria nenhum alcance jurídico ou prático, pois os dois tipos de tratados, uma vez ratificados e em vigor na esfera internacional, têm o mesmo valor para o Direito Internacional Positivo, não existindo entre eles a hierarquia que existe, no direito interno, entre contrato e lei. ${ }^{102}$ Entretanto, pondera CElso D. DE Albuquerque Mello que tal distinção "apresenta valor no tocante à aplicação das regras de interpretação". ${ }^{103}$ Ademais, para AMÉRICO PLÁ

\footnotetext{
${ }^{102}$ Segundo ARNALDO SÜSSEKIND, defendem tal posição Hans Kelsen e Charles Rousseau, in op. cit. (Direito Internacional...), p. 38. Em igual sentido, NGUYEN Q. Dinh, PATRICK DAILliER e Alain Pellet, op. cit., p. 124.

${ }^{103}$ Op. cit., p. p. 164-165 apud ARNALDO SÜSSEKIND, op. cit. (Direito Internacional...), p. 39.
} 
RODRIGUEZ, teria tal questão uma outra repercussão importante, relacionada à solução da seguinte questão: as obrigações que contraem os Estados-Membros da Organização Internacional do Trabalho, ao ratificar uma convenção, existem frente à Organização ou frente aos outros Estados que também a ratificaram? ${ }^{104}$

\subsubsection{As Convenções Internacionais do Trabalho como Tratados-leis}

Os tratados-leis podem ser definidos como aqueles que se prestam a estabelecer normas de conduta gerais e abstratas. Normalmente, admitem um número ilimitado de partes; unem vontades comuns que perseguem um mesmo fim; têm objetos, resultados e obrigações semelhantes para todas as partes; e podem produzir efeitos jurídicos que vão além do círculo de contratantes (efeitos objetivos). ${ }^{105}$

No que tange às convenções internacionais do trabalho, GEORGE SCELLE foi um dos primeiros a destacar as suas características normativas, ao enfatizar que suas disposições fixam normas objetivas aplicáveis a diversas coletividades estatais. Sustenta, ainda, o citado autor serem as convenções da OIT verdadeiras leis internacionais ditadas por um organismo legislativo de mesmo caráter (a Conferência Internacional do Trabalho) e que para adquirirem força legislativa interna somente necessitam de um ato-condição (a ratificação), que, por sua vez, nada mais seria do que a adesão do Estado-Membro a um ato legislativo preexistente (ato-regra). ${ }^{106}$

ARNALDO SÜSSEKIND encampa parcialmente essa teoria, asseverando que:

(...) as convenções aprovadas pela Conferência Internacional do Trabalho são classificadas como tratados-leis, os quais têm sido comparados a leis, porque formulam regras ou princípios, de ordem geral, destinados a reger certas relações internacionais; estabelecem normas gerais de ação; confirmam ou modificam costumes adotados entre as nações. Em regra, resultam de congressos ou conferências e contribuem para a formação do direito internacional. ${ }^{107}$

Todavia, com maior precisão terminológica, tal autor adverte, escorado nas lições de Américo Plá Rodriguez, que as convenções não corresponderiam propriamente a

\footnotetext{
${ }^{104}$ AMÉriCO PlÁ RODRIGUEZ, op. cit., p. 286.

105 ARNALDO SÜSSEKIND, op. cit. (Direito Internacional...), p. 37.

106 Op. cit., p. p. 182-185 apud NiCOLAS VALTiCOS, op. cit., p. 146.

107 ARNALDO SÜSSEKIND, op. cit. (Direito Internacional...), p. 189.
} 
leis supranacionais, porquanto a Conferência Internacional não seria efetivamente um parlamento universal, capaz de impor normas aos diversos Estados, sem que houvesse, no plano interno, a aprovação por suas respectivas autoridades.

Não obstante esse fato, os adeptos desta corrente ${ }^{108}$ insistem em acentuar a função quase-legislativa desempenhada pela Conferência Internacional do Trabalho, que, em verdade, é quem cria as normas constantes da convenção aprovada (ato-regra). Pela sistemática de produção normativa da Organização Internacional do Trabalho, não há que se falar propriamente em uma confluência de vontades entre diferentes Estados, mas de uma decisão tomada pela maioria dos participantes da Conferência (que, como visto no item 3 deste capítulo, não é composta apenas por delegados governamentais). A vontade estatal seria manifestada somente no momento da ratificação da convenção aprovada (atocondição), cuja natureza seria a de um ato unilateral de aceitação das normas criadas pela Conferência, manifestada perante a própria OIT. Por tais motivos, é possível sustentar que as obrigações decorrentes da ratificação não seriam assumidas frente a outros Estados, senão ante a Organização Internacional do Trabalho. ${ }^{109}$

\subsubsection{As Convenções Internacionais do Trabalho como tratados-contratos}

Os tratados-contratos, diferentemente dos tratados-leis, não têm o escopo de criar regras gerais e abstratas, mas de regular assuntos concretos, assemelhando-se, nesse ponto, a negócios jurídicos. Dessa forma, são caracterizados por conciliar interesses diversos entre as partes contratuais; gerar obrigações distintas entre as partes; produzir efeitos jurídicos, geralmente, apenas entre os contratantes (efeitos subjetivos). ${ }^{110}$

ERNEST MAHAIM foi quem, com maior afinco, sustentou serem as convenções internacionais do trabalho tratados-contratos. ${ }^{111}$ Para ele, nem todas as convenções estabeleceriam normas gerais, havendo também aquelas (com cláusula de reciprocidade) que constituem verdadeiros contratos comutativos, como é o caso da convenção referente à igualdade de trato entre nacionais e estrangeiros, em matéria de

\footnotetext{
108 Além de George Scelle e Arnaldo Süssekind, informa AMÉRICO PlÁ RoDRIGUEZ que também seriam defensores da corrente que sustenta terem as convenções a natureza de tratados leis: Basdevant, Oersted, Olivetti e Zarras. In op. cit., p. 286. Cumpre destacar, outrossim, que o próprio AMÉRICO Plá RODRIGUEZ, se inclina por essa posição doutrinária. In Op. cit., p. p. 296-297.

${ }^{109}$ AMÉRICO PlÁ RODRIGUEZ, op. cit., p. p. 287-290.

${ }^{110}$ ARNALDO SÜSSEKIND, op. cit. (Direito Internacional...), p. 37.

111 Segundo AMÉRICO PLÁ RODRIGUEZ, também seriam partidários da posição contratualista autores como Rapisardi Mirabelli, Ramadier e Amiaud. In op. cit., p. 290.
} 
reparação a acidentes de trabalho. Tal fato seria, portanto, a demonstração de que os compromissos previstos nas convenções seriam contraídos pelos Estados não apenas frente à Organização Internacional do Trabalho, mas igualmente diante dos demais países membros. Em decorrência, a OIT representaria unicamente uma união internacional, constituída essencialmente para facilitar, provocar e tornar efetivos acordos internacionais entre Estados em matérias relacionadas ao trabalho. No que tange às consequiências jurídicas das convenções no âmbito interno dos Estados, advindas da ratificação, assevera ERNEST MAHAIM serem elas equivalentes às obrigações contraídas por membros de uma associação constituída a um fim comum, que implicam restrições às soberanias estatais, mas que não derivam exatamente da conclusão da convenção. ${ }^{112}$

\subsubsection{Posição Mista}

IANOULOFF apresenta uma posição intermediária. ${ }^{113}$ Assevera que as convenções internacionais do trabalho teriam uma natureza híbrida, sendo, em parte, tratados-leis e, em parte, tratados-contratos. Justifica sua asserção afirmando que as convenções, pelo simples fato de sua aprovação, já teriam certo valor internacional, gerando certas obrigações aos Estados-Membros da Organização Internacional do Trabalho; porém, tal valor não se converteria realmente em um valor legislativo, senão pelo assentimento das autoridades competentes em cada país. ${ }^{114}$

\subsection{As Convenções Internacionais do Trabalho como Figuras Inéditas} no Direito Internacional

A par das posições acima expostas, que têm em comum o fato de considerarem as convenções da OIT como tratados em sentido amplo, convivem opiniões que as colocam como institutos originais e típicos do Direito Internacional do Trabalho, apresentando, pois, uma natureza jurídica sui generis. ${ }^{115}$

\footnotetext{
${ }^{112}$ Quelques Questions de Droit au Sujet des Conventions Internacionales du Travail, RIT, t. 20, p. p. 511segs, apud, AMÉRICO PLÁ RODRIGUEZ, op. cit., p. p. 291-293.

${ }^{113}$ Compartilham da mesma opinião Nicolas Valticos e Albert Thomas. In NicOlas VALTiCOS, op. cit., p. p. 146-147.

${ }_{114}^{114}$ Op. cit., p. 570, apud AMÉRICO Plá RODRIGUEZ, op. cit., p. p. 295-296.

${ }^{115}$ Nesse sentido, cf. WALKÜRE LOPES Ribeiro DA SilVA, op. cit., p. 110 e WAGNER D. GigliO, op. cit., p. p. 43-44.
} 
Argumenta WAGNER D. GIGLIO que a natureza das convenções não exsurge da artificial comparação com os tratados. Para ele,

(...) as comparações são válidas para distinguir as espécies componentes do mesmo gênero; no caso, porém, a essência da convenção repele sua classificação como tipo especial de tratado. Medularmente, tratados são instrumentos formais que regulam relações entre Estados. As convenções não têm essa essência, pois visam isonomia das várias legislações nacionais, na regulamentação interna das condições de vida dos trabalhadores. ${ }^{116}$

Prossegue afirmando, ainda, referido autor que:

(...) a estrutura anterior não comporta reforma tão ampla a ponto de tornar possível a adaptação desse novo instituto, a convenção internacional do trabalho, aos moldes tradicionais. Trata-se de um fenômeno 'sui generis', que faz parte de um direito baseado em princípios sociais e filosóficos diversos daqueles que fundamentaram a construção jurídica anterior. $^{117}$

Há que se ressaltar, no entanto, que essa corrente doutrinária adota como premissa uma noção muito restritiva do conceito de tratado internacional, enquadrando em tal categoria jurídica somente aqueles instrumentos normativos internacionais escritos, bilaterais, discutidos e elaborados por plenipotenciários de cada um dos Estados contratantes, e que visam ao estabelecimento de vantagens recíprocas entre ambos. Tais elementos caracterizam o que AMÉRICO PlÁ RODRIGUEZ denomina de tratados diplomáticos comuns, que atualmente seriam apenas mais uma espécie do gênero dos tratados internacionais. ${ }^{118}$

De fato, desde meados do século XIX, o conceito de tratados internacionais começou a ser alargado, com a implantação definitiva do tratado multilateral como uma das principais formas de elaboração do direito convencional. ${ }^{119}$

No século XX, o surgimento de novos sujeitos do Direito Internacional Público - as organizações internacionais - redimensionou novamente o conceito. O reconhecimento de que referidas organizações teriam capacidade para elaboração de tratados internacionais multilaterais por meio de seus órgãos permanentes deu contornos

\footnotetext{
${ }^{116}$ Op. cit., p. p. $43-44$.

117 Op. cit., p. 44.

118 Op. cit., p. p. 230-231 e 282.

${ }^{119}$ NGUYen Q. Dinh, PATRICK DAILlier e Alain Pellet, op. cit., p. 169.
} 
finais ao conceito amplo que se encontra, hoje, consolidado na ciência jurídica e na prática internacional, conforme já exposto no item 4.1 deste mesmo tópico.

Modernamente, não há, pois, como deixar de reconhecer que as convenções internacionais do trabalho, por suas características gerais, enquadrem-se no conceito de tratados internacionais em sentido amplo.

\section{RATIFICAÇÃO}

\section{1. Conceito de Ratificação}

O Direito Internacional Público, tradicionalmente, tem como um de seus pilares o respeito à soberania do Estado. Com base nesse princípio, sempre se justificou a existência de um procedimento pelo qual o país deva manifestar, no âmbito internacional, seu consentimento formal em obrigar-se às disposições de um tratado.

Referido procedimento, geralmente, não se aperfeiçoa apenas com a assinatura do tratado pelos plenipotenciários dos Estados após o processo de negociação. Isso porque, na prática internacional, nem sempre os negociadores correspondem às autoridades investidas do chamado treaty-making power $^{120}$, sendo necessário, portanto, que estas verifiquem se aqueles não agiram com excesso de poderes ou contrariamente a suas instruções. Decorre daí a imprescindibilidade de um ato confirmatório da intenção do Estado em se submeter às disposições da norma internacional. Tal ato corresponde ao que o Direito Internacional Público consagrou como ratificação. ${ }^{121}$

Nesse sentido, a Convenção de Viena sobre Direito dos Tratados de 1969 prescreve em seu art. 2, b, que 'se entende por 'ratificação', 'aceitação', 'aprovação' e 'adesão', segundo o caso, o ato internacional assim denominado, pelo qual o Estado faz constar, no âmbito internacional, seu consentimento em obrigar-se por um tratado”.

Em igual direção caminha a doutrina internacionalista. Com efeito, GuIDO FERNANDO SILVA SOARES conceitua a ratificação como o:

\footnotetext{
${ }^{120}$ De acordo com JOSÉ FRANCISCO REZEK, o treaty-making power é "aquela competência que a ordem jurídica própria a cada Estado costuma partilhar entre o governo e o parlamento. Não é uma competência negocial: é o poder de determinar, em definitivo, a disposição do Estado em relação ao compromisso". In op. cit.(Direito dos Tratados...), p. 202.

${ }^{121}$ No caso específico das Convenções Internacionais do Trabalho, dadas as peculiares relacionadas a seu processo de elaboração (confira-se a respeito o item 3 do capítulo II), não se pode cogitar nem mesmo em assinatura da convenção pelos plenipotenciários dos Estados.
} 
(...) ato unilateral do Estado, que reafirma perante seu ou seus co-participantes num tratado sua intenção de obrigar-se por ele; nos tratados bilaterais, a ratificação perfaz-se perante o outro Estado-parte, por uma nota diplomática endereçada à missão diplomática estrangeira, ou perante a Chancelaria do outro país, e nos tratados multilaterais com uma nota diplomática endereçada ao depositário do tratado, um dos Estados-partes indicados pelo Tratado, ou um alto funcionário representante de uma organização intergovernamental (o Secretário Geral, no caso da ONU, ou outra pessoa que tenha a representação de uma organização internacional), se esta for o depositário do tratado multilateral. ${ }^{122}$

Para José FrANCISCO REZEK, a "ratificação é o ato unilateral com que o sujeito de direito internacional, signatário de um tratado, exprime definitivamente, no plano internacional, sua vontade de obrigar-se" ${ }^{, 123}$.

Dos conceitos acima expostos é possível inferir que, por sua própria natureza, a ratificação é, antes de tudo, um ato regulado pelo Direito Internacional. Todavia, não há como negar que também o Direito interno de cada Estado exerce influência sobre a disciplina desse instituto. Com efeito, o poder de ratificar um tratado corresponde a um atributo da soberania dos Estados. Incumbe, portanto, às constituições de cada país, por meio da repartição interna de competências entre as diversas autoridades estatais, definir quais delas deverão exercer essa parcela do poder soberano e quais regras deverão ser observadas em tal exercício. ${ }^{124}$

Finalmente, cumpre destacar que a ratificação é um ato discricionário do Estado e, dentro dele, - como pondera Celso D. DE Albuquerque Mello ${ }^{125}$ - um ato discricionário normalmente do Poder Executivo, que pode recusar-se a ratificar um tratado, ainda que aprovado pelo Legislativo ou, até mesmo, revogar uma ratificação que já tenha sido dada, mas ainda não depositada ou trocada. Além disso, pode o Executivo simplesmente deixar de submeter o tratado ao Legislativo se não tiver a intenção de ratificá-lo, ficando isto a seu critério. Para o mencionado jurista tal inferência encontra-se consagrada no art. $7^{\circ}$ da Convenção Pan-Americana de 1928, sobre tratados, cujo conteúdo merece ser transcrito:

\footnotetext{
${ }^{122}$ Curso de Direito Internacional Público, Vol. I, São Paulo, Atlas, 2002, p. p. 69-70.

123 Op. cit., p. 267.

$124 \mathrm{O}$ tema referente à disciplina da ratificação das convenções pelo Direito brasileiro será objeto de abordagem no Capítulo IV, quando serão tratadas, em tópico específico, as questões relacionadas à integração desses instrumentos ao sistema jurídico nacional.

${ }^{125}$ Op. cit., p. 118. Nesse mesmo sentido confira-se JOSÉ FRANCISCO REZEK, op. cit. (Direito dos

Tratados...), p. 269.
} 
Art. $7^{\circ}$. A falta de ratificação ou de reserva são atos inerentes à soberania nacional e, como tais, constituem o exercício de um direito que não viola nenhuma disposição ou boa norma internacional. Em caso de negativa, esta será comunicada aos outros contratantes.

\subsection{Regras de Direito Internacional Aplicáveis à Ratificação das Convenções Internacionais do Trabalho}

Prescreve o art. $5^{\circ}$ da Convenção de Viena sobre Direito dos Tratados que suas disposições aplicam-se "a todo tratado que seja o instrumento constitutivo de uma organização internacional e a todo tratado adotado no âmbito de uma organização internacional, sem prejuízo de quaisquer normas relevantes da organização" (grifos ausentes no texto original).

Tal preceptivo evidencia, como bem observa ARNALDO SÜSSEKIND, a prevalência das regras específicas adotadas pela Organização Internacional do Trabalho acerca da ratificação de suas convenções, em detrimento dos preceitos existentes no Direito Internacional geral aplicáveis aos demais tratados. ${ }^{126}$

A principal regra sobre a ratificação das convenções internacionais do trabalho encontra-se expressa no art. $19, \S 5^{\circ}, d$, da Constituição da Organização Internacional do Trabalho, nos seguintes termos:

5. Tratando-se de uma convenção:

(...)

d) o Estado-Membro que tiver obtido o consentimento da autoridade, ou autoridades competentes, comunicará ao Diretor-Geral a ratificação formal da convenção e tomará as medidas necessárias para efetivar as disposições da dita convenção.

A autoridade referida na regra é aquela dotada do treaty-making power, ou seja, do poder de aceitar definitivamente o compromisso internacional. Essa não se confunde, necessariamente, com as autoridades competentes para efeitos de submissão das

${ }^{126}$ Op. cit., p. 223. 
convenções, conforme vaticinado no art. $19, \S 5^{\circ}, b$, da Constituição da OIT. Todavia, há, em grande parte das Constituições dos países membros da Organização, certa coincidência entre essas autoridades, já que aos órgãos encarregados do poder de legislar também é atribuída competência para participar do procedimento de ratificação.

Contrariamente à prática adotada nos tratados diplomáticos tradicionais, na ratificação das convenções internacionais do trabalho não há que se cogitar em assinaturas prévias por parte dos plenipotenciários dos Estados, tampouco em intercâmbio dos documentos de ratificação. Isso se deve ao processo especial de elaboração dessas normas jurídicas internacionais (aprovadas em uma conferência permanente composta por delegados não apenas dos governos, mas de segmentos da sociedade civil) e ao seu caráter multilateral.

Além dessas características específicas, assinala Nicolas VALTiCOS que a obrigação supra transcrita de comunicar ao Diretor-Geral a ratificação formal quando a autoridade competente haja dado seu consentimento constitui uma exceção à regra geralmente admitida em Direito Internacional relativa à total discricionariedade do órgão estatal investido deste poder. ${ }^{127}$

A relevância da comunicação da ratificação ao Diretor-Geral reside no fato de que somente através de sua realização é que o consentimento do Estado em obrigar-se aos ditames da convenção exterioriza-se no plano internacional, gerando efeitos em tal órbita, como, por exemplo, a submissão do país ao procedimento especial de controle de aplicação de suas disposições (queixas e representações), realizado pela própria Organização Internacional do Trabalho.

Embora não haja norma escrita no seio da Organização disciplinando a questão da comunicação da ratificação, o Bureau Internacional do Trabalho tem exigido alguns requisitos mínimos para a validade do ato, dentre os quais: a identificação clara da convenção objeto de ratificação; a assinatura da comunicação por uma autoridade que a praxe internacional reconheça o poder de atuar em nome do Estado (Chefe de Estado, Primeiro Ministro, Ministro das Relações Exteriores etc.); a identificação clara de que se trata de uma ratificação formal, sendo preferível uma referência expressa ao art. $19, \S 5^{\circ}, d$, da Constituição da OIT. ${ }^{128}$

\footnotetext{
${ }^{127}$ Op. cit., p. 476.

${ }^{128}$ GERALDO W. VON POTOBSKY e HÉCtOR G. BARTOLOMEI de La CRUZ, op. cit., p. p. 71-72.
} 
Outra especificidade identificável à ratificação das convenções internacionais do trabalho consiste na inadmissibilidade de reservas. Embora não haja um preceito específico na Constituição da OIT sobre a questão, a regra deflui da própria estrutura e objetivos da Organização, bem como, do exclusivo processo existente para a adoção das convenções.

De fato, a aprovação desses instrumentos, como já se referiu, não é semelhante aos dos tratados tradicionais, porquanto realizada no âmbito de um órgão deliberativo permanente, com estrutura e funções quase-legislativas - a Conferência Internacional do Trabalho. Assim, por essa peculiar sistemática de produção normativa, resulta que no processo de elaboração das convenções (ato-regra) não haja, exatamente, uma confluência de vontades entre os Estados que irão tomar parte desses tratados multilaterais, mas uma decisão tomada pela maioria dos integrantes da Conferência. Com base em tais considerações, concluem Geraldo W. vON POTOBSKy e HÉctor G. BARTOLOMEI DE LA CRUZ que as convenções "escapan a la pertinencia de cualquiera de las partes intervenientes y también de los demás Estados ratificantes, por lo qual sería imposible solicitar su autorización para efectuar una reserva". ${ }^{129}$

Demais disso, a admissibilidade de reservas atentaria contra o escopo da evolução uniforme da legislação laboral que motivou a própria criação da Organização Internacional do Trabalho e deporia contra o caráter universal de suas convenções.

A esse respeito, mister registrar, ainda, a existência, no âmbito da Organização, de soluções adequadas para os problemas relacionados aos diferentes graus de desenvolvimento sócio-econômicos dos países. Essas soluções não se identificam, de modo nenhum, à ratificação com reservas. Correspondem elas às chamadas fórmulas de flexibilidade, inseridas no próprio texto das convenções e que podem permitir distintos modos de aplicação de seus dispositivos ou estabelecer diferentes níveis de proteção para uma mesma matéria.

Em razão dessas fórmulas, algumas convenções prevêem que suas ratificações sejam acompanhadas de declarações adicionais de caráter obrigatório ou facultativo. $^{130}$

129 “(...) escapam à pertinência de qualquer das partes intervenientes e também dos demais Estados ratificantes, pelo que seria impossível solicitar sua autorização para efetuar uma reserva" (tradução livre). In Op. cit., p. 74.

${ }^{130}$ As Convenções que contém essa previsão são as de n. 24, 25, 63, 77, 78, 78, 79, 81, 90, 97, 102, 103, 106, $109,110,115,118,119,121,123,128,129,130,132,138,143,146,148,153,155,160,165,168$. 
Nos casos em que se contemplam declarações obrigatórias, normalmente são insertas nas convenções certas regras flexíveis que: oferecem soluções alternativas sobre determinadas questões; estabelecem que o Estado, ao ratificá-las, aceite ou não partes específicas do conteúdo desses instrumentos; permitem que o país aderente fixe o nível e a forma em que a aplicação da norma é aceita. Em tais situações a ratificação somente terá validade se houver referida declaração, com a indicação objetiva da opção ou opções requeridas pela convenção. ${ }^{131}$

No que concerne às declarações facultativas, estas normalmente destinam-se a: permitir aos países derrogações ou exclusões de certas partes ou normas contidas nas convenções; ampliar o campo de incidência das convenções. Na primeira das situações, a abstenção do Estado em efetuar a declaração será considerada como renúncia à faculdade que lhe concedeu o tratado. Na segunda, como se trata de ampliação do nível de proteção, a declaração poderá ser efetuada a qualquer tempo perante o Diretor-Geral do Bureau Internacional do Trabalho.

Se por um lado não se admite a ratificação com reservas, a Organização Internacional do Trabalho aceita, sem maiores dificuldades, a chamada ratificação condicional das convenções. Nessa hipótese, não se põem em questão a aceitação do conjunto das disposições, o que seria impossível como explicado acima, mas se subordina a data de entrada em vigor da convenção para o Estado interessado à sua ratificação por outros países. Essa modalidade especial de ratificação encontrou sua inspiração, essencialmente, na preocupação com a competição internacional, ou seja, no temor dos países em perderem competitividade pelo acréscimo unilateral de seus custos laborais, caso outros Estados não contraíssem simultaneamente os mesmos compromissos. ${ }^{132}$

No entanto, informa a doutrina que essa prática, usada principalmente nos primeiros anos após a criação da Organização Internacional do Trabalho (quando foram registradas treze ratificações desse tipo), caiu em desuso após a Segunda Guerra, período em que foram realizadas apenas duas ratificações condicionais. ${ }^{133}$

Finalmente, cumpre destacar que, uma vez comunicada a ratificação de uma convenção internacional do trabalho ao Diretor-Geral do Bureau, este efetuará o seu registro na própria Organização Internacional do Trabalho e notificará todos os Estados-

\footnotetext{
131 ARNALDO SÜSSEKIND, op. cit. (Direito Internacional...)

${ }^{132}$ NiCOLAS VALTiCOS, op. cit., p. 477.

133 Nesse sentido, Nicolas Valticos, op. cit., p. 477, Geraldo W. von Potobsky e HÉctor G. BARTOlOMEI DE la CRUZ, op. cit., p. 73 e ARNALDO SÜSSEKIND, op. cit. (Direito Internacional...), p. 228.
} 
Membros para dar-lhes ciência sobre esse registro. Mencionada regra, apesar de não vir expressa na Constituição da OIT, conta com previsão na parte referente às disposições finais da maioria das convenções.

Afora o registro efetuado no âmbito da própria Organização, estabelece o art. 20 da Constituição da OIT que o Diretor-Geral do Bureau Internacional do Trabalho deverá também comunicar a ratificação ao Secretário-Geral das Nações Unidas, para fins de registro na ONU, por força do disposto no art. 102 da Carta das Nações Unidas.

\section{VIGÊNCIA INTERNACIONAL}

A questão da vigência das convenções internacionais é disciplinada em suas próprias cláusulas finais ${ }^{134}$ e pode ser analisada sob dois prismas: a) o da entrada em vigor da convenção no plano internacional (também conhecida como vigência internacional ou vigência objetiva), e b) o da entrada em vigor da convenção em relação a cada Estado individualmente considerado (vigência subjetiva).

A vigência internacional ou objetiva decorre, em regra, da ratificação da convenção por, no mínimo, dois Estados-Membros e da fluência de um prazo de doze meses contados dos depósitos das citadas ratificações no Bureau Internacional do Trabalho. ${ }^{135}$

A vigência subjetiva, por sua vez, pressupõe que a convenção já esteja em vigor internacionalmente e se dá, geralmente, após o decurso de doze meses após o registro da ratificação pelo Estado-Membro. ${ }^{136}$ Caso ainda não tenha sido iniciada a vigência objetiva da convenção, a ocorrência das mencionadas condições não implicará a imediata

\footnotetext{
${ }^{134}$ Confira-se a respeito o item 2.2 deste Capítulo.

135 Geraldo W. VON POTOBSKy e HÉctor G. BARTOlOMEI DE la CRUZ explicam que a regra dos doze meses foi estabelecida a partir de 1928. Entre 1919 e 1926, as convenções entravam e vigor objetivamente após a comunicação feita pelo Diretor-Geral do Bureau Internacional do Trabalho de que haviam sido ratificadas por dois Estados-Membros. Em 1927, adotou-se o prazo de noventa dias a partir da segunda ratificação. Informam, outrossim, que algumas convenções sobre trabalho dos marítimos adotam critérios diferentes, como um número maior de ratificações (normalmente de dez países) e, ainda, o condicionamento das ratificações a um somatório específico da tonelagem de mercadorias que a marinha mercante desses países representaria (cem milhões de toneladas). In op. cit., p. p. 74-75.

${ }^{136}$ GERALDO W. VON POTOBSKY e HÉCTOR G. BARTOLOMEI DE LA CRUZ, apontam, também em relação à questão da vigência subjetiva, exceções à regra geral. Estas dizem respeito: ao critério utilizado entre 1919 e 1926 (início no dia do registro da ratificação); ao prazo fixado em 1927 (noventa dias a partir do registro da ratificação); alguns prazos especiais estabelecidos nas convenções sobre trabalho marítimo (normalmente de seis meses a partir do registro da ratificação). In op. cit., p. 75.
} 
entrada em vigor da convenção para o país, ficando as obrigações nelas dispostas submetidas a uma condição suspensiva.

ARNALDO SÜSSEKIND salienta, entretanto, que as disposições adjetivas, inclusive aquelas que tratam da própria questão da vigência da convenção, começam a vigorar desde o momento em que o instrumento adotado pela Conferência Internacional do Trabalho, é assinado pelo seu Presidente e pelo Diretor-Geral do Bureau Internacional do Trabalho. Além disso, informa que a convenção, uma vez em vigor no plano internacional, tem sua vigência indeterminada. Desse modo, mesmo que ocorram sucessivas denúncias e o número de países vinculados à convenção se torne inferior ao número exigido para o início da vigência internacional, esta não se suspende. ${ }^{137}$

\section{REVISÃO}

Como visto no item 2 deste capítulo, as convenções internacionais do trabalho destinam-se, sobretudo, a produzir efeitos na órbita jurídica interna de cada Estado, a fim de estabelecer a uniformização da regulamentação das relações de trabalho. Tal objetivo, contudo, jamais poderá ser alcançado se alterações dos textos adotados forem realizadas com excessiva freqüência. Destarte, é possível inferir que os referidos instrumentos normativos reclamam certo grau de estabilidade, não apenas, conforme sinaliza NiCOLAS VALTiCOS, como forma de se garantir a segurança das relações internacionais e nacionais ${ }^{138}$, mas, igualmente, para permitir o alcance da finalidade supracitada.

Não obstante isso, mostra-se inaceitável que a regulação internacional do trabalho revista-se de normas rígidas e imutáveis. Como bem explana ARNALDO SÜSSEKIND,

assim como as leis sociais de cada país sofrem, no tempo, modificações ditadas por fatores os mais diversos, também os instrumentos internacionais de proteção ao trabalho têm de ser alterados, seja em razão das observações colhidas com sua aplicação ou das dificuldades apontadas para a integração de suas normas no direito interno dos Membros da Organização, seja em virtude do progresso alcançado em relação ao respectivo tema por

${ }^{137}$ Op. cit. (Direito Internacional...), p. p. 193-194.
${ }^{138}$ Op. cit., p. 233. 
grande parte das legislações nacionais ou por inúmeros outros fatores que justificam o reexame do diploma anterior. ${ }^{139}$

Imprescindível, portanto, que se procurasse estabelecer um ponto de equilíbrio entre a necessidade intrínseca de estabilidade das convenções internacionais do trabalho e o reclamo da adaptação de suas disposições ao tempo. A solução encontrada pela Organização Internacional do Trabalho para harmonizar, de maneira satisfatória, essas duas necessidades aparentemente contraditórias foi a de disciplinar a revisão de seus instrumentos por meio de um procedimento que contempla certo número de formalidades e prazos com o intuito de serem evitadas modificações açodadas.

A Constituição da OIT não contém disposições relativas à revisão das convenções internacionais do trabalho, porém, o Regulamento do Conselho de Administração e o Regulamento da Conferência Internacional do Trabalho constituem um estatuto completo sobre o tema.

De maneira sucinta, prevêem um procedimento, mutatis mutandi, análogo ao da elaboração das convenções. Cabe ao Conselho de Administração, com base em informativos fornecidos pelo Bureau Internacional do Trabalho e após consulta aos governos dos Estados, decidir se é desejável inscrever, na ordem do dia da Conferência, a revisão de uma convenção. Caso haja a referida inscrição, o Bureau submete à Conferência Internacional do Trabalho os projetos de reforma da convenção, elaborados com base nas conclusões do Conselho. O exame pela Conferência do projeto de revisão segue um procedimento idêntico ao da segunda discussão, utilizada na elaboração das convenções pelo sistema de dupla discussão (ver item 3.3 deste capítulo).

Não bastasse esse regramento, no texto de algumas convenções, costuma-se incluir igualmente regras sobre sua revisão. De maneira recorrente nos últimos anos, tais regras têm aparecido com a seguinte redação:

Cada vez que estime necessário, o Conselho de Administração da Repartição Internacional do Trabalho apresentará à Conferência um relatório sobre a aplicação da Convenção, e considerará a conveniência de incluir na ordem do dia da Conferência a questão da sua revisão total ou parcial.

No caso em que a Conferência adote uma nova convenção que implique uma revisão total ou parcial da presente, e a menos que a nova convenção contenha disposições em contrário:

${ }^{139}$ Op. cit. (Direito Internacional...), p. 198. 
a) a ratificação, por um Membro, da nova convenção revisora implicará, ipso jure, a denúncia imediata desta Convenção, não obstante as disposições contidas no artigo (referente à limitação da denúncia a cada dez anos de vigência da ratificação), sempre que a nova convenção revisora haja entrado em vigor;

b) esta convenção continuará em vigor, em sua forma e conteúdo atuais, para os Membros que a tenham ratificado e não ratifiquem a convenção revisora.

Da análise dos preceitos transcritos, permite-se a conclusão de que uma convenção revista não estará mais aberta a novas ratificações. Porém, caso um Estado a tenha ratificado anteriormente e, porventura, não haja adotado a revisão, o texto revisto continuará em vigor para ele. Essa dualidade de regimes, embora não seja desejável, tendo em consideração o escopo de uniformização das legislações nacionais pretendido pela OIT, é inevitável, em razão da própria natureza jurídica das convenções. Como tratados-leis, esses instrumentos normativos possuem uma estrutura complexa, compreendendo um atoregra (o texto aprovado pela Conferência) e um ato-condição (a adesão do país por meio da ratificação). A revisão atinge, em princípio, somente o ato-regra, porquanto é realizada pela Conferência Internacional e esta, em razão do princípio da soberania, não pode constituir-se como um parlamento universal, capaz de impor normas aos diversos Estados, sem que haja, no plano interno, a aprovação por suas respectivas autoridades.

ARNALDO SÜSSEKIND adverte, ainda, que as mencionadas regras se aplicam nas hipóteses em que haja uma revisão formal da convenção. No caso de ocorrer a aprovação de um diploma que verse sobre um mesmo assunto já tratado em outro anterior, mas sem que se adote o procedimento de revisão, a Organização Internacional do Trabalho não o considerará como um instrumento de revisão, permanecendo ambas as convenções abertas à ratificação dos Estados-Membros, vigendo simultaneamente. ${ }^{140}$

Finalmente, informam GERALdo W. vON Potobsky e Héctor G. BARTOLOMEI DE LA CRUZ que, entre 1974 e 1979, houve um exame detalhado das normas da Organização Internacional do Trabalho, realizado por um Grupo de Trabalho designado pelo Conselho de Administração. No curso desses estudos, surgiu a idéia de se adotar um novo mecanismo de revisão das convenções: o protocolo. As características desse novo instrumento são bastante assemelhadas à de uma convenção de revisão, pois deve ele ser aprovado pela Conferência, com a maioria de dois terços dos votantes e está sujeito à obrigação de submissão à autoridade competente para fins de ratificação. No entanto, seu

${ }^{140}$ Op. cit. (Direito Internacional...), p. 200. 
advento pode ser explicado por motivos de ordem prática, pois evita a existência de duas convenções sobre a matéria e possibilita que imediatamente sejam visualizadas as diferenças entre o texto original e a sua atualização. Ademais, tal mecanismo distingue-se da sistemática anterior, por permitir que a redação revista permaneça aberta à ratificação por Estados que ainda não haviam aderido à convenção. Desse modo, tem o país a faculdade de ratificar somente o texto original da convenção ou, além dele, também o seu protocolo de revisão. ${ }^{141}$

\section{ClassificaÇÃo}

Classificar é a atividade de distribuir determinados objetos de uma mesma família em classes ou categorias, estabelecidas segundo um critério lógico de diferenciação. A maior ou menor acuidade da atividade classificatória está intimamente relacionada ao estabelecimento de critérios dotados de alto grau de objetividade e exatidão. Por outro lado, a relevância de uma determinada classificação liga-se fundamentalmente à sua utilidade em revelar a existência de um regime próprio para cada uma das categorias.

No que tange ao problema da classificação das convenções internacionais do trabalho, observa-se, na Ciência Jurídica, a utilização de uma pluralidade de métodos.

$\mathrm{Na}$ doutrina especializada, uma das mais tradicionais classificações é apresentada por AMÉRICO PlÁ RodRIGUEZ. Ao escoliar as lições do autor francês Amiaud, afirma o jurista uruguaio que, tendo em consideração o conteúdo das convenções, é possível dividi-las em quatro classes: de uniformidade, de princípios, de igualdade de direitos e de procedimentos.

As convenções de uniformidade são as que têm como escopo estabelecer normas cujas disposições devam ser aplicadas como leis nacionais sobre o território de todos os Estados que as ratificam. Constituem, portanto, o sistema mais direto que a Organização Internacional do Trabalho dispõe para lograr seu objetivo de promover a unificação do direito laboral de seus membros.

As convenções de princípios, por sua vez, são aquelas que estabelecem diretrizes que devem servir de inspiração para a aprovação de leis ou outros atos complementares pelos países que as ratificam.

${ }^{141}$ Op. cit., p. 58. 
As convenções de igualdade de direitos correspondem àquelas que têm por finalidade assegurar a isonomia no tratamento de trabalhadores nacionais e estrangeiros dentro do território dos países que as ratificam, relativamente aos assuntos nelas versados, bem como, o estabelecimento de regras para a solução de conflitos de leis no espaço.

Finalmente, as convenções de procedimentos são as que versam exclusivamente sobre outras convenções, ou seja, são as que estatuem disposições de natureza formal, como, por exemplo, a Convenção n. 80 que reviu os artigos finais das convenções adotadas antes da Segunda Guerra Mundial. ${ }^{142}$

Em direção muito próxima à classificação supra, ARNALDO SÜSSEKIND divide as convenções internacionais do trabalho em três categorias, levando em conta a natureza de suas normas: as auto-aplicáveis, as de princípios e as promocionais.

As primeiras possuem disposições que não demandam uma regulamentação complementar para serem aplicadas pelos Estados que as ratificam. Destarte, nos países que consagram o monismo jurídico, a ratificação da convenção importará a imediata integração de seus preceitos ao ordenamento jurídico interno, ao passo que, nos países que consagram o dualismo, bastará a reprodução do conteúdo da convenção ratificada pela legislação nacional.

As segundas dependem, para tornarem-se efetivas, da elaboração de leis ou outros atos regulamentares que deverão ser realizados no prazo de doze meses entre a ratificação e o início da vigência da convenção no âmbito nacional.

As últimas correspondem às convenções que fixam objetivos e estabelecem programas para a sua consecução, os quais devem ser atendidos pelos Estados que as ratificam mediante providências sucessivas, a médio e longo prazo. ${ }^{143}$

Também com base no seu conteúdo, porém, com enfoque maior sobre as matérias por elas tratadas, NiCOLAS VALTiCOS distribui as convenções internacionais do trabalho de acordo com os seguintes temas: direitos humanos fundamentais (liberdade sindical, trabalho forçado e discriminação); emprego; condições de trabalho e política social; seguridade social; relações profissionais; proteção dos jovens; trabalho feminino; categorias especiais de trabalhadores; e administração do trabalho. ${ }^{144}$

Digna de nota, por fim, é a classificação efetuada pelo próprio Conselho de Administração da Organização Internacional do Trabalho que, com esteio no critério da

\footnotetext{
142 Op. cit., p. p. 233-235.

143 ARNALDO SÜSSEKIND, op. cit. (Direito Internacional...), p. p. 190-191.

${ }^{144}$ Op. cit., p. 238.
} 
relevância para o sistema normativo internacional, divide as convenções em três categorias: as fundamentais, as prioritárias e as demais convenções. ${ }^{145}$

As convenções fundamentais correspondem àquelas normas que a própria Organização considera como a expressão dos princípios e direitos que, segundo ela, constituem os pilares de sua Constituição, ou seja, a liberdade sindical e o reconhecimento efetivo de negociação coletiva; a eliminação de todas as formas de trabalho forçado ou obrigatório; a abolição efetiva do trabalho infantil; e a eliminação da discriminação em matéria de emprego e ocupação. Enquadrar-se-iam nessa categoria as seguintes convenções: a Convenção n. 87, sobre Liberdade Sindical e Proteção ao Direito de Sindicalização; a Convenção n. 98, sobre Direito de Sindicalização e de Negociação Coletiva; a Convenção n. 29, sobre Abolição do Trabalho Forçado; a Convenção n. 105, igualmente, sobre Abolição do Trabalho Forçado; a Convenção n. 138, sobre Idade Mínima para Admissão em Emprego; a Convenção n. 182, sobre as Piores Formas de Trabalho Infantil; a Convenção n. 100, sobre Igualdade de Remuneração; e a Convenção n. 111, sobre Discriminação em Matéria de Emprego e Ocupação.

As convenções prioritárias, embora não digam, diretamente, respeito aos princípios e direitos fundamentais inscritos na Constituição da OIT, foram assim consideradas porque se revestem de especial importância para o correto funcionamento do sistema de normas internacionais do trabalho. São elas: a Convenção n. 81, sobre Inspeção do Trabalho na Indústria e no Comércio; a Convenção n. 129, sobre Inspeção do Trabalho na Agricultura; a Convenção n. 144, sobre Consultas Tripartites; e a Convenção n. 122, sobre Política de Emprego.

Sem pretender realizar uma análise meritória sobre a precisão e a utilidade das classificações mencionadas, deve-se destacar que, para os propósitos desta dissertação, nenhuma delas mostra-se suficientemente adequada. De fato, como já destacado no capítulo introdutório, um dos objetivos centrais da presente monografia é tratar justamente do problema da integração das convenções internacionais do trabalho na ordem jurídica nacional. Nesse tocante, merece especial atenção o fato de que a Constituição Federal brasileira prevê regimes jurídicos distintos para a incorporação dos tratados, segundo um único critério: versarem ou não tais instrumentos sobre direitos humanos (art. $5^{\circ}, \S \S 2^{\circ}$ e $3^{\circ}$,

145 IVANna dos Santos Gomes, A Atividade Normativa da OIT: Convenções, Recomendações e Sua Contribuição para o Direito Internacional do Trabalho, in ÉMERSON JOSÉ ALVES LAGE e MÔNICA SETTE LOPES, O Direito do Trabalho e o Direito Internacional - Questões Relevantes, São Paulo, LTr, 2005, p. 121. 
da CF). Fundamental, por conseguinte, que as convenções internacionais do trabalho sejam classificadas segundo essas duas classes, sendo imperioso, para tanto, que se estabeleçam critérios objetivos e exatos para esse enquadramento.

Não se objeta que essa classificação já tenha sido esboçada por alguns autores $^{146}$ e, sobretudo, pela própria Organização Internacional do Trabalho que, com a Declaração sobre os Princípios e Normas Fundamentais no Trabalho de 1998, enumerou oito convenções havidas como fundamentais. Inobstante tal fato, percebe-se uma falha nessas posições relativa, exatamente, à elucidação dos critérios que conduziram à identificação de quais convenções apresentariam e quais não apresentariam em seu conteúdo matérias relativas a direitos humanos.

Embora seja possível verificar alguns pontos de contato em muitas das classificações que pretendem subdividir as convenções em relação às categorias citadas, a questão ainda suscita muitas dúvidas no campo doutrinário. A esse respeito afirma OSCAR ERMIDA URIARTE:

cuales son los convenios y recomendaciones de la OIT sobre derechos humanos, es cuestión objeto de debate doctrinal. Hay quienes sostienen que casi todos los convenios son sobre derechos humanos, ya que la mayor parte de los derechos laborales por ellos abordados tienen esa naturaleza, excluyendo solamente algunos convenios sobre temas estadísticos o puramente técnicos. En el otro extremo se situaría una eventual lectura hiperrestrictiva de la Declaración de 1998, que pretendería ver en ella un numerus clausus. ${ }^{147}$

\footnotetext{
${ }^{146}$ Como sublinhado em linhas pretéritas, NiCOLAS VALTiCos é um dos que já se debruçou sobre o tema, apontando como convenções de direitos humanos as que tratam sobre: liberdade sindical (Convenções n. 11, 84, 87 e 98); abolição do trabalho forçado (Convenções n. 29 e 105); e eliminação da discriminação em matéria de emprego e ocupação (Convenção n. 111). In op. cit., p. p. 239-281. Semelhante classificação é adotada por GERALDO W. VON POTOBSKY e HÉCTOR G. BARTOLOMEI DE LA CRUZ, op. cit., p. p. Também ARNALDO SÜSSEKIND abordou tal questão, arrolando como convenções de direitos humanos as seguintes: Convenção n. 87 (sobre liberdade sindical e proteção ao direito de sindicalização); Convenção n. 198 (sobre direito de sindicalização e de negociação coletiva); Convenção n. 104 (sobre abolição de sanções penais por incumprimento de contrato de trabalho por parte de trabalhadores indígenas); Convenção n. 105 (sobre abolição do trabalho forçado); Convenção n. 100 (sobre igualdade de remuneração entre homens e mulheres); Convenção n. 111 (sobre não discriminação em matéria de emprego e ocupação); Convenção n. 138 (sobre abolição do trabalho infantil e idade mínima para o emprego); Convenção n. 122 (sobre política de emprego); Convenção n. 169 (sobre povos indígenas e tribais em países independentes); e Convenção n. 182 (sobre proibição das piores formas de trabalho infantil). In op. cit.(Direito Internacional...), p. p. 126-127.

147 "Quais são as convenções e recomendações da OIT sobre direitos humanos é uma questão objeto de debate doutrinal. Há quem sustente que quase todas as convenções são sobre direitos humanos, já que a maior parte dos direitos laborais por elas abordada tem essa natureza, excluindo somente algumas convenções sobre temas estatísticos ou puramente técnicos. No outro extremo, situar-se-ia uma eventual leitura hiper-restritiva da Declaração de 1998, que pretenderia ver nela um numerus clausus" (tradução livre). Derechos Humanos Laborales en el Derecho Positivo Urugayo, in HUGO BARRETO GHIONE, Investigación sobre la Aplicación de los Principios y Derechos Fundamentales en el Trabajo en Uruguay, Lima, OIT, 2006, p. 79.
} 
Tendo em vista alguns dos mencionados aspectos, realizar-se-á, no terceiro capítulo desta dissertação, uma breve exposição dos principais temas relacionados à questão dos direitos humanos, tendo em vista a sua relevância para a problemática da integração das convenções internacionais do trabalho à ordem jurídica brasileira. Buscarse-á, sobretudo, o estabelecimento de critérios objetivos que permitam a identificação daquelas convenções internacionais do trabalho que possam ser consideradas como tratados internacionais de direitos humanos, bem como, uma singela explanação dos princípios estruturantes do sistema de direitos fundamentais, aplicáveis, via de conseqüência, a essas convenções. 


\section{CAPÍTULO III - DIREITOS HUMANOS E CONVENÇÕES DA ORGANIZAÇÃO INTERNACIONAL DO TRABALHO}

\section{Teoria Geral dos Direitos Humanos}

Inicialmente, mostra-se necessária uma advertência quanto ao plano de desenvolvimento deste segmento. Por uma opção metodológica, não há a pretensão de esgotar todas as questões relacionadas à temática dos direitos humanos. Primeiro, porque o assunto é extremamente vasto, comportando múltiplas e incontáveis perspectivas de análise, o que justificaria, per se, o desenvolvimento de teses específicas com tal objeto. Segundo, porque o cerne da presente dissertação é o estudo das principais características das convenções da Organização Internacional do Trabalho e da integração desses instrumentos à ordem jurídica pátria, sendo o exame das questões relativas ao universo temático dos direitos humanos algo apenas subsidiário à perfeita compreensão dessas matérias.

Por outro lado, uma investigação meramente perfunctória de tão importante setor do conhecimento jurídico mostra-se incompatível com os escopos deste trabalho. Isso porque algumas noções revelam-se essenciais não apenas para o delineamento das convenções da Organização Internacional do Trabalho que apresentariam as características de tratados internacionais de direitos humanos, mas também para a realização do estudo relativo à integração desses instrumentos ao sistema jurídico nacional, já que a dinâmica própria dos direitos humanos influencia determinantemente a forma como isso ocorre.

Desse modo, busca-se neste tópico trazer a lume, sob o título "Teoria Geral dos Direitos Humanos", uma compilação sistemática dos principais assuntos tratados por significativa parte da doutrina que se ocupa do tema direitos humanos, de modo a apresentar um panorama geral, porém suficiente aos propósitos definidos para esta pesquisa acadêmica. 


\section{1. Conceito de Direitos Humanos}

ANDRÉ DE CARVALHO RAMOS, em brilhante monografia sobre o tema dos direitos humanos na ordem internacional apresenta, com base nas lições de Antonio Enrique Perez Luño, três modalidades de conceituação desses direitos. ${ }^{148}$

A primeira delas, denominada de tautológica, não traz consigo nenhum elemento novo para a caracterização dos direitos humanos, como sói ocorrer com a já tradicional fórmula de que estes seriam os direitos correspondentes ao homem pelo fato de ser homem.

A segunda modalidade é aquela que apresenta uma definição meramente formal, ou seja, que não especifica propriamente o conteúdo dos direitos humanos, limitando-se a indicar alguns aspectos de seu regime jurídico especial. Seria exemplo desse tipo de conceituação a proposição segundo a qual "os direitos humanos são aqueles que pertencem ou devem pertencer a todos os homens e que não podem ser deles privados, em virtude de seu regime indisponível e sui generis". ${ }^{149}$

Finalmente, há uma terceira forma de se definir os direitos humanos, que leva em consideração o conteúdo próprio desses direitos, bem como, os seus objetivos, podendo, nesse sentido, os conceitos que se utilizam desses critérios serem chamados de finalísticos ou teleológicos. Dentre eles, avulta como um dos mais precisos o conceito elaborado por ANTONIO-ENRIQUE PEREZ LUÑO que define os direitos humanos como:

(...) un conjunto de faculdades e instituciones que, en cada momento histórico, concentran las exigencias de la dignidad, la liberdad y la igualdad humanas, las cuales deben ser reconocidas positivamente por los ordenamientos jurídicos a nível nacional e internacional. $^{150}$

Esse conceito, além de revelar que os direitos humanos são produto do desenvolvimento histórico, também traz subjacente os seus valores nucleares, assim como,

\footnotetext{
148 Teoria Geral dos Direitos Humanos na Ordem Internacional, Rio de Janeiro, Renovar, 2005, p. 17.

149 ANDRÉ DE CARVALHO RAMOS, op. cit., p. 18.

150 “(...) um conjunto de faculdades e instituições que, em cada momento histórico, concentram as exigências de dignidade, liberdade e igualdade humanas, as quais devem ser reconhecidas positivamente pelos ordenamentos jurídicos a nível nacional e internacional" (tradução livre). In Los Derechos Fundamentales, $7^{\mathrm{a}}$ ed., Madrid, Tecnos, 1998, p. 46.
} 
a noção de que a efetivação desses direitos depende, em grande parte, do seu reconhecimento expresso em instrumentos normativos nacionais e internacionais. Embora esteja longe de ser um consenso, a definição supra transcrita parece refletir com maior precisão a concepção teórica atual sobre o tema.

\subsection{Fundamento e Natureza dos Direitos Humanos}

Há um grande dissenso doutrinário acerca da fundamentação dos direitos humanos, isto é, das razões que legitimam e motivam o seu reconhecimento. ${ }^{151}$

Em um primeiro momento, há estudiosos que se inclinam pela impossibilidade de se fundamentar tais direitos. NORBERTO BOBBIO, com base em distintos argumentos, afirma, com vigor, que a pesquisa em torno de um fundamento absoluto para os direitos humanos é infundada. Em primeiro lugar, sustenta o mestre italiano que a expressão "direitos humanos" seria muito vaga e imprecisa, pairando dúvidas, inclusive quanto à definição do que seriam tais direitos. Tal fato, por si, impediria a busca de um fundamento para essa categoria, pois não seria possível fundamentar algo cuja própria determinação é duvidosa. Em segundo lugar, assevera que a noção de direitos humanos é variável no tempo, mudando de sentido e amplitude conforme o contexto histórico. Assim, não se permitiria um fundamento unívoco, havendo em cada época razões justificativas distintas. Finalmente, defende que os direitos humanos formam uma categoria heterogênea (que pode encerrar, inclusive, pretensões conflitantes), obstando, dessa forma, a elucubração sobre um fundamento único e absoluto. ${ }^{152}$ Daí concluir o insigne jurista que "o problema fundamental em relação aos direitos do homem, hoje, não é tanto o de justificálos, mas o de protegê-los. Trata-se de um problema não filosófico, mas político". 153

Em direção oposta à tese negacionista apresentada por Norberto Bobbio parece caminhar a maior parte da doutrina. Deveras, permanece presente na Ciência Jurídica a idéia de que a fundamentação dos direitos humanos é de capital importância não apenas para permitir a delimitação do conteúdo desses direitos, mas também para assegurar que a sua proteção ocorra de maneira efetiva. ${ }^{154}$

\footnotetext{
151 ANDRÉ DE CARVALHO RAMOS, op. cit., p. 35.

${ }^{152}$ A Era dos Direitos, trad. port. de Carlos Nelson Coutinho, São Paulo, Campus, 1992, p. 19-22.

${ }^{153}$ NORBERTO BOBBIO, op. cit., p. 24.

${ }^{154}$ Como bem adverte JORGE MIRANDA, "renunciar à fundamentação dos direitos humanos pode consistir, para muitos, na resignação perante as leis positivas vigentes ou perante as contingências de sua aplicação".
} 
$\mathrm{Na}$ busca de um fundamento para os direitos humanos, várias construções teóricas foram elaboradas. Nesse sentido, existem correntes que perfilham a idéia de que seriam eles direitos inatos ou naturais. Outras sustentam a tese de que seriam direitos positivos. Existe, ainda, quem se posicione na linha de que os direitos humanos derivariam de um determinado sistema moral. ${ }^{155}$

Sem pretender entrar no mérito de quais seriam os acertos e equívocos de cada uma dessas teorias que procuram identificar o fundamento dos direitos humanos, este estudo abraçará a posição que, se não for a prevalente, tem gozado, no mínimo, de grande prestígio dentre os principais juristas que se ocupam da análise de questões pertinentes a tais direitos: a que coloca o próprio homem, considerado em sua dignidade substancial de pessoa, como o fundamento último e transcendental dessa categoria de direitos.

Com muita propriedade, explica FÁBIo KONDER COMPARATO que "se o direito é uma criação humana, o seu valor deriva, justamente, daquele que o criou". ${ }^{156}$ Destarte, o fundamento para a vigência dos direitos humanos encontra-se além da organização estatal, correspondendo, em última instância à consciência ética coletiva, ou seja, a convicção longa e largamente estabelecida no meio social de que a dignidade humana impõe a observância a certos valores, independentemente de seu reconhecimento por uma ordem estatal ou em normas internacionais. ${ }^{157}$

Como conseqüência da adoção desse fundamento, emerge a concepção que enxerga os direitos humanos como tendo uma natureza histórica, ou seja, como produtos culturais advindos de um longo processo histórico de lutas pela afirmação da dignidade humana. ${ }^{158}$

In Manual de Direito Constitucional, Vol. IV, 2 a ed., Coimbra, Coimbra Editora, 1993, p. 43 apud ANDRÉ DE CARVALHO RAMOS, op. cit., p. 38.

${ }^{155}$ A esse respeito, conferir ANDRÉ DE CARVAlHo RAMOS, op. cit., p. 39-47.

${ }^{156}$ Fundamento dos Direitos Humanos, Instituto de Estudos Avançados da Universidade de São Paulo, disponível em www.iea.usp.br/artigos, p. 7. Acesso em 14/10/2008.

${ }^{157}$ A Afirmação Histórica dos Direitos Humanos, $3^{a}$ ed. São Paulo, Saraiva, 2004, p. p. 57-59. Entretanto, o próprio jurista admite que o reconhecimento oficial desses direitos, por uma autoridade política, seja no plano internacional, seja no plano interno, confere-lhes um maior grau de efetividade e, portanto, maior segurança jurídica às relações sociais. Além disso, a positivação desses direitos atende a um fim pedagógico, concernente na prevalência dos grandes valores éticos, que sem um reconhecimento oficial, demorariam a se impor na vida em comunidade.

${ }_{158}$ Defendem tal posição, dentre outros juristas, Hannah Arendt, Flávia Piovesan, Ignacy Sachs, Joaquim Herrera Flores, Allan Rosas, Carlos Santiago Niño e Fábio Konder Comparato. A esse respeito, conferir-se: Flávia PIovesan, Direitos Sexuais e Reprodutivos - Aborto Inseguro como Violação aos Direitos Humans, in Daniel SARMEnto e Flávia Piovesan (coord.), Nos Limites da Vida - Aborto, Clonagem Humana e Eutanásia sob a Perspectiva dos Direitos Humanos, Lumen Iuris, Rio de Janeiro, 2007, p. 54; e FÁBIO KONDER COMPARATO, op. cit (A Afirmação...), p. 36. 
A razão da historicidade dos direitos humanos reside no próprio fato de que o homem é um ser inacabado, em constante processo evolutivo. Com efeito, como bem explica FÁBIO KONDER COMPARATO:

(...) se o próprio homem, e não a divindade ou a natureza de modo geral, é o fundamento do universo ético, a História nos ensina que o reconhecimento dessa verdade só foi alcançado progressivamente, e que a sua tradução em termos jurídicos jamais será concluída, pois ela não é senão o reflexo do estado de 'permanente inacabamento' do ser humano (...). ${ }^{159}$ (Grifos ausentes do texto original).

Partindo de tal pressuposto, relevante se torna, pois, a realização de uma análise das principais etapas da afirmação dos direitos humanos na História, como forma de compreendê-los adequadamente.

\subsection{Desenvolvimento Histórico dos Direitos Humanos}

\subsubsection{A Antiguidade}

Embora haja na doutrina que se ocupa do estudo dos direitos humanos uma tendência em situar o início do reconhecimento histórico desses direitos a partir das revoluções ocorridas no século XVIII ${ }^{160}$, não há como negar que os primórdios desse longo e amplo processo evolutivo tenham despontado bem antes, ainda na Era Histórica conhecida como Antigüidade.

Nesse sentido INGO WOLFGANG SARLET expõe, com precisão, que a religião e a filosofia daquele período transmitiram ao mundo algumas idéias-chave que exerceram influência direta sobre o pensamento jusnaturalista, sobre o qual repousa a concepção de que o ser humano é titular de alguns direitos naturais e inalienáveis, em decorrência do simples fato de existir. Por tal razão, assevera que tal fase é considerada como a "préhistória" dos direitos humanos. ${ }^{161}$

Em igual direção FÁBIO KONDER COMPARATO, com fundamento nas lições de Karl Jaspers, aponta a existência de uma época, compreendida entre os séculos VIII e II a.C., que seria considerado o eixo histórico da humanidade e, por tal razão, designada

${ }^{159}$ FÁBIO KONDER COMPARATO, op. cit. (A Afirmação...), p. 36

${ }^{160}$ Nesse sentido, confira-se FÁBIO KONDER COMPARATO, op. cit. (A Afirmação...), p. 49.

${ }^{161}$ A Eficácia dos Direitos Fundamentais, $8^{\mathrm{a}}$ ed. Porto Alegre, Livraria do Advogado, 2007 , p. 45. 
como Período Axial. No centro desse período, entre 600 e 480 a.C, teriam coexistido os maiores doutrinadores de todos os tempos: Zaratrusta, Buda, Lao-Tsé, Confúcio, Pitágoras e Dêutero-Isaías. Tais doutrinadores instituíram visões de mundo que representaram uma grande linha divisória na História, pois, a partir desse momento, abandonaram-se as explicações mitológicas e o curso histórico passou a constituir um desdobramento das idéias e princípios expostos no referido período. No Período Axial, portanto, é que se enunciaram os grandes princípios e diretrizes fundamentais de vida em vigor até os dias atuais. $^{162}$

De fato, os valores da liberdade, igualdade entre todos os homens e dignidade da pessoa humana têm suas origens associadas à filosofia clássica e à fé monoteísta. Do Antigo Testamento, herdou-se a idéia de que o ser humano representa o ponto culminante da criação divina. Já a doutrina estóica greco-romana e o cristianismo legaram ao mundo as teses da unidade da humanidade e da igualdade de todos os homens em dignidade. ${ }^{163}$

Acerca da importância do mundo antigo para a evolução histórica dos direitos humanos, conclui FÁBIO KONDER COMPARATO que:

(...) é a partir do período axial que, pela primeira vez na História, o ser humano passa a ser considerado, em sua igualdade essencial, como ser dotado de liberdade e razão, não obstante as múltiplas diferenças de sexo, raça, religião ou costumes sociais. Lançavam-se, assim, os fundamentos intelectuais para a compreensão da pessoa humana e para a afirmação da existência de direitos universais, porque a elas inerentes. ${ }^{164}$

\subsubsection{A Limitação do Poder Político}

Como bem afirma FÁBIO KONDER COMPARATO, a "eclosão da consciência histórica dos direitos humanos só se deu após um longo trabalho preparatório, centrado na limitação do poder político". ${ }^{165}$ Essa limitação correspondeu à primeira etapa decisiva para o reconhecimento da existência de direitos inerentes à própria condição humana e que, por tal razão, não podem ser vistos como mera concessão dos que detêm o poder.

\footnotetext{
162 Op. cit. (A Afirmação...), p. p. 8-9.

${ }^{163}$ INGO WOLFGANG SARLET, op. cit., p. 45.

164 Op. cit.(A Afirmação...), p. 11.

165 Op. cit. (A Afirmação...), p. 40.
} 
As primeiras experiências de limitação do poder político da História ocorreram ainda na Antigüidade. No século X a. C., o reino de Davi em Israel é marcado como primeiro na História em que o monarca não se declarava deus ou supremo legislador, mas apenas delegado do Deus-único e responsável pela execução da lei divina. Tal fato é tão relevante que pode ser apontado como o germe do Estado de Direito, em que o governante não cria o direito para justificar o seu poder, submetendo-se aos princípios e normas de uma autoridade superior. Séculos mais tarde, aproximadamente, em VI a. C, uma nova experiência de limitação institucional do poder surge com as primeiras instituições democráticas em Atenas e prossegue, no século subseqüente, com a república de Roma. Com a democracia ateniense, são fixados os princípios da primazia da lei e da participação dos cidadãos no governo. Na república romana, a limitação do poder deu-se graças à instituição de um complexo sistema de controles recíprocos entre os diferentes órgãos políticos. ${ }^{166}$

É, no entanto, na Idade Média que surge o documento referido pelos autores que se dedicam ao estudo evolutivo dos direitos humanos como um dos antecedentes mais importantes para a esse processo inicial de limitação de poder: trata-se da Magna Carta, firmada na Inglaterra em 1215.

A Magna Carta foi um pacto proposto pelas autoridades eclesiásticas e barões feudais ingleses ao rei João Sem-Terra e por ele firmado em 1215. Naquele momento histórico, a supremacia do poder real sobre os senhores feudais havia se enfraquecido. Paralelamente, João Sem-Terra entrou em conflito também com o papado, ao tomar o partido imperial na querela das investiduras em cargos eclesiásticos. Diante de uma revolta armada dos barões, o rei se viu obrigado a assinar a Magna Carta, como condição para a cessação das hostilidades advindas da nobreza e do clero. ${ }^{167}$

Referido documento serviu, portanto, para garantir certas prerrogativas à Igreja e alguns privilégios feudais aos nobres ingleses. Por tal razão, não há como caracterizar como autênticos direitos fundamentais as disposições contidas na Magna Carta, já que foram outorgadas no contexto de uma sociedade estamental e dirigidas a apenas duas castas minoritárias, alijando a grande parcela da população do seu gozo. Não obstante tal fato, sua importância histórica avulta por ter servido como referência para alguns direitos e liberdades civis clássicos - tais como, o habeas corpus, o devido processo

\footnotetext{
${ }^{166}$ FÁBio KONDER COMPARATO, op. cit. (A Afirmação...), p. p. 40-43.

${ }^{167}$ FÁBIO KONDER COMPARATO, op. cit. (A Afirmação...), p. p. 71-72.
} 
legal e a garantia da propriedade ${ }^{168}$ - mas, sobretudo, por ter deixado implícito, pela primeira vez na história medieval, o fato de o rei achar-se vinculado pelas próprias leis que edita. $^{169}$

A etapa seguinte desse processo de limitação de poder tem como marcos dois outros documentos ingleses: a Lei de Habeas Corpus e o Bill of Rights, ambos do século XVII e, portanto, já na Era Moderna.

Os dois séculos subseqüentes ao final da Idade Média foram marcados, na Europa, pelo agravamento da concentração de poderes. Esse fato fez com que a consciência dos perigos representados pelo poder absoluto e o sentimento de liberdade reaparecessem na Inglaterra. A par disso, durante o reinado dos Stuart, últimos católicos a governar a Inglaterra, o Parlamento, composto majoritariamente de protestantes, usou de todos os meios para limitar o poder do rei, sobretudo, o de prender os opositores políticos, sem submetê-los a um devido processo criminal. ${ }^{170}$ É nesse contexto que a Lei do Habeas Corpus de 1679 foi criada. Seu advento, esclareça-se, não introduziu o instituto do habeas corpus no Direito inglês, mas o dotou de real eficácia, ao estabelecer regras processuais adequadas ao seu exercício.

A importância histórica do Habeas Corpus Act salienta FÁBIO KONDER COMPARATO “consistiu no fato de que essa garantia judicial, criada para proteger a liberdade de locomoção, tornou-se matriz de todas as que vieram a ser criadas posteriormente, para a proteção de outras liberdades fundamentais". ${ }^{171}$

No entanto, cumpre registrar que, a exemplo da Magna Carta, a garantia prevista na referida lei não visava à proteção indistinta de toda a população, mas, tãosomente, do clero e da nobreza. Distinguia-se do documento de 1215 , porém, pelo fato de ter uma formulação mais geral e abstrata, que no final, acabou aproveitando, anos mais tarde, à burguesia rica. ${ }^{172}$

O Bill of Rights foi promulgado em 1689, como resultado da chamada Revolução Gloriosa de 1688. Seu advento dá-se, desse modo, um século antes da Revolução Francesa, sendo o documento que, pela primeira vez, desde o seu surgimento na Europa renascentista, pôs fim ao regime de monarquia absoluta. Por meio dele, limitaramse os poderes do rei de legislar e criar tributos, que passaram à esfera de competências do

\footnotetext{
${ }^{168}$ INGO WOLFGANG SARLET, op. cit., p. 49.

${ }^{169}$ FÁBIO KONDER COMPARATO, op. cit. (A Afirmação...), p. 77.

${ }^{170}$ FÁBIo Konder COMPARATO, op. cit. (A Afirmação...), p. p. 47-48, 85

${ }^{171}$ Op. cit. (A Afirmação...), p. 86.

${ }^{172}$ FÁBIO KONDER COMPARATO, op. cit. (A Afirmação...), p. 48.
} 
Parlamento. Representou, portanto, a institucionalização da permanente separação de poderes na Inglaterra. ${ }^{173}$

Assevera FÁBio KONDER COMPARATO que "a partir do Bill of Rights britânico, a idéia de um governo representativo, ainda que não de todo o povo, mas pelo menos de suas camadas superiores, começa a firmar-se como garantia institucional indispensável das liberdades civis". ${ }^{174}$

Explica, entretanto, INGO WoLfGANG SARLET que, apesar de sua importância na esfera de afirmação dos direitos, servindo, inclusive, como inspiração para declarações que a sucederam, o Bill of Rights não pode ser considerado como o marco inicial para o nascimento dos direitos fundamentais na acepção que se atribui atualmente ao termo. Isso porque os direitos e liberdades individuais nele previstos, a despeito de limitarem o poder do monarca, não vinculavam o Parlamento, carecendo, assim, da necessária supremacia e estabilidade, o que permite inferir que na Inglaterra não houve propriamente a constitucionalização desses direitos e liberdades, mas apenas uma fundamentalização. ${ }^{175}$

\subsubsection{A Afirmação dos Direitos e Liberdades Individuais}

A Independência Americana e a Revolução Francesa legaram ao mundo os primeiros registros solenes de que "todos os homens são igualmente vocacionados, pela sua própria natureza, ao aperfeiçoamento constante de si mesmos". ${ }^{176}$ De fato, as declarações de direitos que resultaram de ambos os movimentos - sobretudo, a Declaração de Independência Norte-americana de 1776 e a Declaração dos Direitos do Homem e do Cidadão, de 1789 - são apontadas como os efetivos marcos iniciais do processo de reconhecimento dos direitos humanos na História.

\footnotetext{
${ }^{173}$ FÁBio Konder COMPARATO, op. cit. (A Afirmação...), p. 90.

${ }^{174}$ Op. cit. (A Afirmação...), p. 48.

175 Op. cit., p. 51.

${ }^{176}$ FÁBIO KONDER COMPARATO, op. cit. (A Afirmação...), p.49.
} 
a) A Independência dos Estados Unidos e as Declarações de Direitos Norte-americanas

Em 4 de julho de 1776, após um longo movimento histórico de independência das treze antigas colônias britânicas da América do Norte, é proclamada a Declaração de Independência dos Estados Unidos.

Tal declaração correspondeu ao primeiro documento político que reconheceu a existência de direitos inerentes a todos os seres humanos, independentemente das diferenças de sexo, raça, religião, cultura e posição social. Além disso, a ela coube a precedência na afirmação dos princípios democráticos na história política moderna, por meio do reconhecimento da soberania popular. ${ }^{177}$ A relevância desse último fato reside na constatação de que os governos são instituídos pelo povo (detentor do poder político supremo), tendo como escopo precípuo a garantia dos direitos naturais de todos os homens.

Os direitos e liberdades individuais que, em sua maioria, já haviam sido reconhecidos pelas declarações inglesas do século XVII, adquiriram, com o movimento de independência norte-americano e as declarações de direitos que dele derivaram ${ }^{178}$, as características da universalidade - sepultando, pelo menos no plano formal, a idéia de que se destinavam apenas a determinadas castas sociais - e da supremacia em relação à representação popular, vinculando, assim, pela primeira vez, todos os poderes públicos. ${ }^{179}$

\section{b) A Revolução Francesa e a Declaração dos Direitos do Homem e do} Cidadão de 1789

O final do século XVIII foi um período marcado pela crise dos antigos regimes da Europa e seus sistemas econômicos, produzindo, em todo o continente, profundas agitações políticas durante suas últimas décadas. O caso da França, no entanto, era diferenciado. Por se constituir como a mais poderosa das velhas aristocráticas monarquias absolutas da Europa, o conflito entre a estrutura oficial, os interesses estabelecidos do velho regime e as novas forças sociais ascendentes era muito mais intenso

\footnotetext{
${ }^{177}$ FÁBIO KONDER COMPARATO, op. cit. (A Afirmação...), p.p. 102-103.

${ }^{178}$ A Declaração de Independência dos Estados Unidos da América do Norte é a principal, mas não as únicas das cartas de direitos que advieram do movimento de independência das colônias norte-americanas. Poucas semanas antes de sua proclamação, o Estado de Virgínia já havia feito sua Declaração em 12 de junho de 1776. A elas se seguiram as declarações da Pennsylvania, de 16 de agosto de 1776, e de Massachusetts, de 1780.

${ }^{179}$ INGO WOLFGANG SARLET, op. cit., p. 52.
} 
nesse país. O citado fator, embora esteja por trás da Revolução Francesa, como um de seus principais motivos ensejadores, não pode, porém, ser apontado como o estopim do movimento revolucionário. Sua eclosão, na realidade, encontra-se diretamente associada à chamada "reação feudal". ${ }^{180}$

A sociedade européia, desde a Idade Média, foi caracterizada por sua divisão em estamentos bem distintos - clero, nobreza e povo. Na França do final do século XVIII, havia uma população de aproximadamente 23 milhões de pessoas, das quais cerca de 400 mil eram nobres. Tais indivíduos gozavam de uma série de privilégios, como, a isenção de impostos e o direito de receber tributos feudais. Todavia, no campo político, sua ação havia sido reduzida ao mínimo com a prevalência do regime absolutista. Economicamente a situação da nobreza não era melhor que sua situação política, já que as suas rendas decorriam essencialmente de suas propriedades e estas se mostravam cada vez menos aptas à manutenção do status de nobre. Natural, dessa forma, que a nobreza reagisse a esse estado de coisas, lançando mão de seu bem principal: os privilégios reconhecidos. Durante todo o século XVIII os nobres compraram, com a cessão de seus títulos, os postos oficiais que a monarquia absoluta preferia preencher com homens da classe média, politicamente inofensivos e tecnicamente competentes. Com isso, a um só tempo, a nobreza exasperou os sentimentos da classe média e corroeu o próprio Estado através da crescente tendência de assumir a administração central e provinciana. Além da mencionada iniciativa, alguns nobres tentaram conter o declínio de suas rendas usando ao máximo seus privilégios feudais para extorquir a enorme massa que compunha o campesinato, despertando também a ira desse segmento da sociedade. ${ }^{181}$

A esse quadro de profunda instabilidade social foi acrescido um cenário crescente de problemas financeiros enfrentados pela monarquia, até que o Estado francês chegou à sua bancarrota final após se envolver na guerra de independência americana. A crise econômica deu à aristocracia a chance de promover um assalto contra a monarquia. A Revolução Francesa começou, desse modo, como uma tentativa da aristocracia em retomar o poder político. Todavia, essa tentativa foi mal calculada, por subestimar as intenções do chamado "Terceiro Estado" - a unidade fictícia composta por todos que não faziam parte da nobreza e do clero - e desprezar a profunda crise sócio-econômica no meio da qual lançava suas exigências políticas. ${ }^{182}$

\footnotetext{
${ }^{180}$ ERIC J HOBSBAWM, op. cit., p. p. 84-87.

${ }^{181}$ ERIC J HOBSBAWM, op. cit., p. p. 87-89.

${ }^{182}$ ERIC J HOBSBAWM, op. cit., p. p. 89-90.
} 
A Revolução Francesa, como adverte ERIC J. HOBSBAWM,

(...) não foi feita e liderada por um partido ou movimento organizado, no sentido moderno, nem por homens que estivessem tentando levar a cabo um programa estruturado. (...) Não obstante um surpreendente consenso de idéias gerais entre um grupo social bastante coerente deu ao movimento revolucionário uma unidade efetiva. O grupo era a 'burguesia'; suas idéias eram as do liberalismo clássico, conforme formuladas pelos 'filósofos' e 'economistas' e difundidas pela maçonaria e associações informais. ${ }^{183}$

O movimento ocorrido na França em 1789 produziu uma total mudança semântica à expressão "revolução". A primazia do uso político de tal palavra é dos ingleses, que a utilizaram para caracterizar a restauração monárquica de 1660, após a ditadura de Cromwell. Indicava, pois, uma volta às origens ou, em termos mais precisos, a restauração dos antigos costumes e liberdades. Nesse sentido, foi tal vocábulo empregado na "Revolução Gloriosa" para designar a restauração das antigas prerrogativas dos súditos diante dos monarcas. Essa mesma acepção aparece também na "Revolução Americana", que teria servido para a reconquista de antigas e costumeiras prerrogativas dos súditos norte-americanos da coroa britânica. ${ }^{184}$ No entanto, após a Revolução Francesa,

(...) o termo passou a ser usado para indicar uma renovação completa das estruturas sociopolíticas, a instauração ex novo não apenas de um governo ou de um regime político, mas de toda uma sociedade, no conjunto das relações de poder que compõem a sua estrutura. Os revolucionários já não são os que se revoltam para restaurar a antiga ordem política, mas os que lutam com todas as armas - inclusive e sobretudo a violência - para induzir o nascimento de uma sociedade sem precedentes históricos. ${ }^{185}$

Esse espírito de renovação, e não de restauração, distingue claramente a Declaração de Direitos do Homem e do Cidadão de 1789 das declarações de direitos dos Estados Unidos. Os americanos preocupavam-se mais em estabelecer sua independência, do que propriamente difundir a idéia de liberdade aos demais povos. Já os revolucionários franceses "julgavam-se apóstolos de um mundo novo, a ser anunciado a todos os povos e em todos os tempos vindouros" ${ }^{186}$. Não por acaso, as idéias propaladas pela Revolução

\footnotetext{
${ }^{183}$ ERIC J HOBSBAWM, op. cit., p. 90.

${ }^{184}$ FÁBIO KONDER COMPARATO, op. cit.(A Afirmação...), p.p. 125-126.

${ }^{185}$ FÁBIO KONDER COMPARATO, op. cit.(A Afirmação...), p. 126.

${ }^{186}$ FÁBIO KONDER COMPARATO, op. cit.(A Afirmação...), p. 130.
} 
Francesa, rapidamente, ressoaram em diferentes regiões do mundo, tais como, Índia e América Latina ${ }^{187}$. Nesse sentido, costuma-se atribuir uma aspiração mais universal e abstrata à Declaração francesa de 1789, em contraste com o pragmatismo das cartas de direitos norte-americanas. ${ }^{188}$

O conteúdo da Declaração dos Direitos do Homem e do Cidadão reflete, contudo, as aspirações da classe que acabou detendo o controle da Revolução Francesa: a burguesia. Trata-se de uma carta de direitos do indivíduo frente ao Estado, ou seja, direitos de defesa que demarcam uma zona de não intervenção desse último sobre a esfera de autonomia de cada cidadão. São, portanto, marcados por uma abstenção e não por uma conduta positiva dos poderes públicos. Dentre esses direitos, assumem especial relevância os direitos à vida, à liberdade, à propriedade e à igualdade perante a lei (igualdade formal).

Sem olvidar a importantíssima contribuição para o processo de afirmação histórica dos direitos humanos - ao precisar os contornos dos chamados direitos e liberdades individuais e lançá-los ao alcance do restante do mundo, em razão do seu caráter abstrato e globalizante, fixando-os, assim, de modo definitivo à consciência ética universal - a Declaração Universal dos Direitos do Homem e do Cidadão de 1789 caracterizou-se como:

(...) um manifesto contra a sociedade hierárquica de privilégios nobres, mas não um manifesto de uma sociedade democrática e igualitária. 'Os homens nascem e vivem livres e iguais perante as leis', dizia seu primeiro artigo; mas ela prevê a existência de distinções sociais, ainda que 'somente no terreno da utilidade comum'. A propriedade privada era um direito natural, sagrado, inalienável e inviolável. Os homens eram iguais perante a lei e as profissões estavam igualmente abertas ao talento; mas, se a corrida começasse sem handicaps, era igualmente entendido como fato consumado que os corredores não terminariam juntos. A declaração afirmava (como contrário à hierarquia nobre ou o absolutismo) que 'todos os cidadãos têm o direito de colaborar na elaboração das leis'; mas 'pessoalmente ou através de seus representantes' e a assembléia representativa que ela vislumbrava como o órgão fundamental de governo não era necessariamente uma assembléia democraticamente eleita, nem o regime nela implícito pretendia eliminar os reis. Uma monarquia constitucional baseada numa oligarquia possuidora de terras era mais adequada à maioria dos liberais burgueses do que a república democrática que poderia ter parecido uma expressão mais lógica de suas aspirações teóricas, embora alguns também advogassem esta causa, mas, no geral, o burguês liberal clássico em 1789 (e o liberal de

\footnotetext{
${ }^{187}$ ERIC J. HOBSBAWM, op. cit., p. 85.

${ }^{188}$ INGO WOLFGANG SARLET, op. cit., p. 53.
} 
1789-1848) não era um democrata, mas sim um devoto do constitucionalismo, um Estado secular com liberdades civis e garantias para a empresa privada e um governo de contribuintes e proprietários. ${ }^{189}$

Algumas das distorções acima apontadas, sobretudo, aquelas reveladoras da insuficiência da declaração de meros direitos e liberdades individuais como forma de assegurar a todos os indivíduos o gozo efetivo de um grau satisfatório de proteção de sua dignidade enquanto ser humano, conduziram a humanidade à etapa seguinte do processo de evolução histórica dos direitos humanos: a afirmação dos direitos econômicos e sociais.

\subsubsection{A Afirmação dos Direitos Humanos de Caráter Econômico e Social}

A Revolução Industrial, que teve seu despontar na Inglaterra, durante as últimas décadas do século XVIII, alastrou-se pelo continente europeu no decorrer do século XIX. Com ela, houve o nascimento de um novo modelo econômico, o capitalismo. Tal modelo amalgamou-se ao liberalismo, que havia se consolidado com a ascensão social da classe burguesa, após a Revolução Francesa. Em um processo de perfeita simbiose, o sistema capitalista encontrou na conformação político-ideológica do Estado Liberal um campo fértil para florescer.

Já no século XIX, advieram os primeiros resultados sociais desse processo: o surgimento de um enorme contingente de trabalhadores urbanos submetidos a condições de vida extremamente precárias e desumanas, como decorrência da ótica liberal, que, sob a majestade da lei, considerava os detentores dos meios de produção e os trabalhadores como contratantes iguais em direitos, bem como, do escopo capitalista, sintetizado na idéia da máxima obtenção de lucro sem se importar com os custos sociais que pudessem resultar disso; a aquisição da consciência de classe por parte dessa massa, por influência da ideologia socialista; a constatação de que a mera consagração formal de liberdade e igualdade era insuficiente para a garantia de seu efetivo gozo por todos os seres humanos; a organização e eclosão do movimento operário, que acirrando a luta entre as classes, galgou espaço para a conquista e consolidação de novos direitos, caracterizados pela sua dimensão prestacional, no sentido de exigir do Estado um comportamento ativo na realização da justiça social.

$\overline{{ }^{189} \text { ERIC J. HOBSBAWM, op. cit., p. } 91 .}$ 
De forma embrionária, a Constituição Francesa de 1848, como fruto das revoluções sociais ocorridas na Europa naquele ano, já havia reconhecido algumas exigências econômicas e sociais em seu artigo 13. Todavia, a plena afirmação dos direitos humanos de caráter econômico e social somente ocorreu no século XX, com a Constituição Mexicana de 1917, a Constituição de Weimar de 1919 e com o Tratado de Versalhes de 1919, que criou a Organização Internacional do Trabalho e iniciou o processo de internacionalização desses novos direitos humanos.

\section{a) A Constituição Mexicana de 1917}

Afirma FÁBio Konder CoMPARATO que a fonte ideológica da Constituição Mexicana de 1917 foi a doutrina anarcossindicalista, difundida, sobretudo, na Rússia, na Espanha e na Itália no século XIX:

O pensamento de Mikhail Bakunin influenciou Ricardo Flores Magón, líder do grupo Regeneración, que reunia jovens intelectuais contrários à ditadura de Porfírio Diaz. O grupo lançou clandestinamente, em 1906, um manifesto de ampla repercussão, no qual se apresentaram as propostas que viriam a ser as linhas-mestras do texto constitucional de 1917: proibição de reeleição do Presidente da República (Porfírio Diaz havia governado mediante reeleições sucessivas, de 1876 a 1911), garantias para as liberdades individuais e políticas (sistematicamente negadas a todos os opositores do presidente-ditador), quebra do poderio da Igreja Católica, expansão do sistema de educação pública, reforma agrária e proteção do trabalho assalariado. ${ }^{190}$

A Constituição Mexicana de 1917 foi a primeira na História a reconhecer, como direitos fundamentais, os direitos do trabalhador, revelando, assim a consciência de que os direitos humanos também têm uma dimensão social. Em reação ao capitalismo e ao liberalismo, a Carta Política do México apreendeu a disparidade material de posição entre empregador e empregado acarretada pela liberdade de contratar, amenizando-a por meio de uma série de disposições tendentes a garantir um mínimo de benefícios à classe economicamente fraca da relação de trabalho. Com isso, lançou as bases para o Estado Social de Direito, fundado nos princípios da solidariedade e da igualdade material e, não mais, na igualdade meramente formal do Estado Liberal.

${ }^{190}$ Op. cit. (A Afirmação...), p. 173. 
A despeito de sua precedência histórica, a Constituição Mexicana não obteve, à sua época, a mesma repercussão, no contexto do reconhecimento dos direitos sociais e econômicos como direitos humanos, que outros dois importantes documentos: a Constituição de Weimar e o Tratado de Versalhes.

\section{b) A Constituição de Weimar de 1919}

Instituidora da primeira república alemã, a Constituição dita de Weimar, cidade da Saxônia onde foi elaborada e votada, surgiu como um produto da grande guerra de 1914-1918, que encerrou o 'longo século XIX'. Promulgada imediatamente após o colapso de uma civilização, ela ressentiu-se desde o início, em sua aplicação, dos tumultos e incertezas inerentes ao momento histórico em que foi concebida. ${ }^{191}$

Ressalta FÁBio Konder COMPARATO que o projeto da Constituição de Weimar sofreu, em sua redação, a influência da antiga doutrina comunitária alemã, o que contribui para que, desde sua concepção, fosse estruturada contraditoriamente, objetivando a conciliação de idéias pré-medievais com exigências liberais-capitalistas ou socialistas da civilização industrial. ${ }^{192}$

Tais circunstâncias teriam determinado a efêmera vigência da Carta Política de Weimar. Todavia, apesar desses fatores, sua contribuição para a incorporação na consciência ética coletiva da dimensão social dos direitos humanos se fez sentir com muito mais intensidade do que a própria Constituição Mexicana. De fato, o conjunto de suas disposições sobre a educação pública e sobre os direitos dos trabalhadores organizou as bases da democracia social, que atingiria seu clímax na segunda metade do século XX. Algumas das disposições da Constituição que, certamente, cumpriram um papel de destaque nesse sentido, foram: o art. 145, que prevê a obrigatoriedade e gratuidade do ensino fundamental; o art. 151, que abre a seção destinada à vida econômica, prescrevendo que esta deve organizar-se com o fim de assegurar a todos uma existência conforme à dignidade humana; o art. 153, que estabelece a função social da propriedade, dispondo que seu uso deve servir ao bem-comum; o art. 162, que propõe uma regulação internacional das relações jurídicas de trabalho, tendente a criar um padrão mínimo geral de direitos sociais,

${ }^{191}$ FÁBIO KONDER COMPARATO, op. cit. (A Afirmação...), p. 185.
${ }^{192}$ FÁBIO Konder COMPARATO, op. cit. (A Afirmação...), p. 188. 
em franca preocupação com a formação de um mercado internacional de trabalho; o art. 163, que procura assegura o direito ao trabalho.

\section{c) O Tratado de Versalhes de 1919}

Ao final do século XIX, como já destacado em linhas pretéritas, a grande massa de trabalhadores urbanos da Europa e da América do Norte já havia adquirido a necessária consciência de classe para a sua organização em torno de uma ação coletiva estruturada. Mesmo durante o período em que ocorreu a Primeira Guerra Mundial (19141919), foram registradas inúmeras ações sindicais, dentre as quais, merece destaque a Conferência de Leeds (Inglaterra), de 1916. Relata ARNALDO SÜSSEKIND que em tal oportunidade, reuniram-se representantes das organizações sindicais inglesas, francesas, belgas e italianas, sendo aprovada uma resolução que mais tarde constituiria a base da parte do Tratado de Versalhes correspondente à criação da Organização Internacional do Trabalho. ${ }^{193} \mathrm{O}$ preâmbulo da referida resolução, antes mesmo do término da Grande Guerra proclamava:

A conferência declara que o tratado de paz que porá fim a esta guerra e dará às nações independência política e econômica deve também assegurar às classes trabalhadoras de todos os países um mínimo de garantias de ordem moral e material, relativas ao direito de associação, migração, seguro social, higiene, horas de trabalho e proteção, a fim de resguardá-las contra ataques oriundos da competição internacional capitalista.

Além dessa intensa ação sindical, o desenrolar da guerra favoreceu a classe operária na conquista de seu maior objetivo naquele momento: a inclusão no Tratado de Paz de um estatuto que consagrasse as normas de amparo ao trabalhador. Com efeito, a vitória das nações aliadas só foi possível graças à concorrência direta da classe operária, que agiu de forma determinante no front interno da produção bélica e, não raro, engrossou os contingentes militares. Esse fato constituiu esteio sólido para o alcance, por parte dos trabalhadores, das suas reivindicações. ${ }^{194}$

Meses após a instalação da Conferência de Paz foi aprovado o Tratado de Versalhes, cuja parte XIII, criou a Organização Internacional do Trabalho, consagrou, no

193 Op. cit. (Direito Internacional...), p. 96.

194 ARNALDO SÜSSEKIND, op. cit. (Direito Internacional...), p. 97. 
plano internacional, os princípios fundamentais do Direito do Trabalho (art. 427) e, ainda, deixou claro em seu preâmbulo o objetivo da Sociedade das Nações de universalizar as leis social-trabalhistas como medida de proteção aos direitos humanos.

Os direitos sociais adquiriram, após o Tratado de Versalhes, sua plena cidadania, passando a ser reconhecidos, na maioria dos países civilizados, como indispensáveis à preservação da dignidade humana. Deveras, antes mesmo do início da $2^{\mathrm{a}}$ Guerra Mundial, a Organização Internacional do Trabalho já havia aprovado 67 convenções internacionais, dentre as quais, várias obtiveram ratificações de mais de uma centena de Estados, tais como: a Convenção n. 11, de 1921, sobre o direito de associação e coalizão de trabalhadores rurais; a Convenção n. 14, de 1921, sobre descanso semanal nas indústrias; a Convenção n. 19, de 1925, sobre igualdade de tratamento entre trabalhadores estrangeiros e nacionais em matéria de indenização por acidentes do trabalho; a Convenção n. 26, de 1928, sobre métodos para fixação de salários mínimos; e a Convenção n. 29, de 1930, sobre a abolição do trabalho forçado. Não se pode olvidar, portanto, que muitos direitos trabalhistas tenham, a partir de então, passado a integrar a consciência ética universal, não procedendo, nesse sentido, qualquer análise que tente desconsiderá-los objetivamente como direitos humanos. ${ }^{195}$

\subsubsection{A Internacionalização dos Direitos Humanos}

O Tratado de Versalhes de 1919, como visto, ao criar a Organização Internacional do Trabalho, procurou dar aos direitos humanos de dimensão social uma conotação universal. Ao lado dele, parte da doutrina afirma que o Direito Humanitário e a

\footnotetext{
${ }^{195}$ FÁBIO KONDER COMPARATO, ao tecer seus comentários acerca da Constituição Mexicana de 1917, expõe que “(...) não se pode deixar de reconhecer que nem todos os direitos trabalhistas, lá declarados, podem ser considerados, objetivamente, como direitos humanos. A doutrina jurídica alemã contemporânea distingue, nitidamente, os direitos humanos dos direitos fundamentais. Estes últimos são os direitos que, consagrados na Constituição, representam as bases éticas do sistema jurídico nacional, ainda que não possam ser reconhecidos, pela consciência jurídica universal, como exigências indispensáveis de preservação da dignidade". In op. cit. (A Afirmação...), p. 176. A análise transcrita é válida, desde que se admita sua referência restrita ao momento histórico anterior ao Tratado de Versalhes e a universalização dos direitos trabalhistas decorrente da criação da Organização Internacional do Trabalho. Após essa fase, a maioria dos países civilizados passou a reconhecer, como garantias mínimas à dignidade do ser humano, praticamente os mesmos direitos que a Carta Política Mexicana de 1917 já declarava. A partir da criação da Organização Internacional do Trabalho não há como negar que os direitos sociais do trabalhador tenham passado a se incorporar, paulatinamente, à consciência ética universal, não se atendo, pois, somente às bases axiológicas do sistema jurídico de determinada nação ou país.
} 
Convenção da Liga das Nações constituiriam a primeira fase do processo de internacionalização dos direitos humanos. ${ }^{196}$

No entanto, a real consolidação do direito internacional surge em meados do século XX, após a Segunda Guerra Mundial.

Afirma FÁBIo KONDER COMPARATO que:

(...) ao emergir da $2^{\mathrm{a}}$ Guerra Mundial, após três lustros de massacres e atrocidades de toda sorte, iniciados com o fortalecimento do totalitarismo estatal nos anos trinta, a humanidade compreendeu, mais do que em qualquer outra época da História, o valor supremo da dignidade humana. O sofrimento como matriz da compreensão do mundo e dos homens, segundo a lição luminosa da sabedoria grega, veio aprofundar a afirmação histórica dos direitos humanos. ${ }^{197}$

As atrocidades cometidas no holocausto deram ao mundo a percepção de que a proteção dos direitos humanos não deveria limitar-se ao âmbito reservado de um Estado. Nesse quadro, emerge o processo de reconstrução desses direitos, como paradigma ético a orientar a ordem internacional contemporânea.

Nesse sentido, expõe FLÁvia PIOvESAn que:

A necessidade de uma ação internacional mais eficaz para a proteção dos direitos humanos impulsionou o processo de internacionalização desses direitos, culminando na criação da sistemática normativa de proteção internacional, que faz possível a responsabilização do Estado no domínio internacional quando as instituições nacionais se mostram falhas ou omissas na tarefa de proteger os direitos humanos. ${ }^{198}$

Há, como decorrência desse processo, uma revisão do próprio princípio da soberania estatal, não mais tido como absoluto, mas sujeito a certas limitações em favor da defesa dos direito humanos.

Apontam-se como principais marcos históricos desse processo de internacionalização dos direitos humanos a Carta das Nações Unidas de 1945 e a Declaração Universal dos Direitos do Homem de 1948.

196 Confira-se, neste sentido, FÁBIO Konder COMPARAto, op. cit. (A Afirmação...), p.p. 54-55 e FláVIA PIOVESAn, Direitos Humanos e o Direito Constitucional Internacional, $7^{\mathrm{a}}$ ed., São Paulo, Saraiva, 2007, p.p. 107-115.

${ }^{197}$ Op. cit.(A Afirmação...), p. 55.

${ }^{198}$ Op. cit. (Direitos Humanos e o Direito Constitucional Internacional...), p. 117. 
A criação da Organização das Nações Unidas constitui-se o marco de uma nova ordem internacional, caracterizada por um modelo de conduta relacionado a preocupações que incluem não apenas a manutenção da paz e segurança internacional, mas também a adoção da cooperação entre os povos no plano econômico, social e cultural, o desenvolvimento de relações amistosas entre os Estados, a proteção ao meio ambiente e, sobretudo, a proteção internacional dos direitos humanos.

Com precisão, pontua FLÁVIA PIOVESAN que:

A Carta das Nações Unidas de 1945 consolida, assim, o movimento de internacionalização dos direitos humanos, a partir do consenso de Estados que elevam a promoção desses direitos a propósito e finalidades das Nações Unidas. Definitivamente, a relação de um Estado com seus nacionais passa a ser uma problemática internacional, objeto de instituições internacionais e do direito internacional. ${ }^{199}$

Prevê o artigo 68 da Carta das Nações Unida de 1945 que um de seus órgãos, o Conselho Econômico e Social, deveria criar comissões para os assuntos econômicos e sociais e a proteção dos direitos do homem. Em cumprimento a esta disposição, foram aprovadas, em 1946, duas resoluções (5.1, de 16 de fevereiro e 9.2, de 21 de junho) que criaram a Comissão de Direitos Humanos, incumbindo-lhe uma dupla função: a promoção e a proteção da dignidade humana. Como promotor de direitos humanos, incumbe à referida Comissão a elaboração de anteprojetos de declarações e tratados internacionais relativos a esses direitos. Na qualidade de órgão protetor dos direitos humanos pode a referida Comissão iniciar ex officio inquéritos sobre situações de flagrantes e reiteradas violações a direitos humanos, que poderão conduzir à condenação do Estado responsável. Além disso, poderá por em funcionamento um mecanismo ad hoc de vigilância e informação sobre um país ou um tema determinado. ${ }^{200}$

${ }^{199}$ Op. cit. (Direitos Humanos e o Direito Constitucional Internacional...), p. p. 127-128.
${ }^{200}$ FÁBIO Konder COMPARATO, op. cit. (A Afirmação...), p.p. 213-214. 


\title{
b) A Declaração Universal dos Direitos do Homem de 1948
}

\author{
Explica FÁBIo KONDER COMPARATO que:
}

(...) a Declaração Universal de 1948 representa a culminância de um processo ético que, iniciado com a Declaração de Independência dos Estados Unidos e a Declaração dos Direitos do Homem e do Cidadão, da Revolução Francesa, levou ao reconhecimento da igualdade essencial de todo ser humano em sua dignidade de pessoa, isto é, como fonte de todos os valores, independentemente das diferenças de raças, cor, sexo, língua, religião, opinião, origem nacional ou social, riqueza, nascimento, ou qualquer outra condição, como se diz em seu artigo II. E esse reconhecimento universal da igualdade humana só foi possível quando ao término da mais desumanizadora Guerra de toda a história, percebeu-se que a idéia de superioridade de uma raça, de uma classe social, de uma cultura ou de uma religião, sobre todas as demais, põe em rico a própria sobrevivência da humanidade. ${ }^{201}$

O objetivo da Declaração Universal dos Direitos do Homem é o delineamento de uma ordem pública mundial, fundada no respeito à dignidade humana. ${ }^{202}$ Seu artigo I traz a síntese dos princípios axiológicos fundamentais em direitos humanos: liberdade, igualdade, fraternidade e dignidade humana, ao dispor que: "todos os homens nascem livres e iguais em dignidade e direitos. São dotados de razão e consciência e devem agir em relação uns aos outros com espírito de fraternidade".

Conclui Flávia PIOVESAn que:

\begin{abstract}
a Declaração de 1948 introduz extraordinária inovação ao conter uma linguagem de direitos até então inédita. Combinando o discurso liberal da cidadania com o discurso social, a Declaração passa a elencar tanto direitos civis e políticos (art. $3^{\circ}$ a 21 ) como direitos sociais, econômicos e culturais (arts. 22 a 28). ${ }^{203}$
\end{abstract}

Finalmente, cumpre ressaltar, que dentro dessa etapa de internacionalização dos direitos humanos, a Declaração Universal de Direitos do Homem de 1948 teve seu conteúdo desenvolvido, de forma pormenorizada, em 16 de dezembro de 1966, com a adoção pela Assembléia Geral das Nações Unidas de dois pactos internacionais: O Pacto Internacional sobre Direitos Civis e Políticos e o Pacto Internacional sobre Direitos

\footnotetext{
201 Op. cit. (A Afirmação...), p. 225.

${ }^{202}$ Flávia Piovesan, op. cit. (Direitos Humanos e o Direito Constitucional Internacional...), p.131.

${ }^{203}$ Flávia Piovesan, op. cit. (Direitos Humanos e o Direito Constitucional Internacional...), p.133.
} 
Econômicos, Sociais e Culturais. Além desses pactos, o processo de internacionalização dos direitos humanos também é complementado pela adoção de Convenções em âmbito regional, dentre as quais, destacam-se: A Convenção Européia para a Proteção dos Direitos Humanos e das Liberdades Fundamentais, aprovada em Roma, em 4 de janeiro de 1950; a Convenção Americana de Direitos Humanos, aprovada na Conferência de São José da Costa Rica, em 22 de novembro de 1969; a Carta Africana dos Direitos Humanos e dos Direitos dos Povos, aprovada na $18^{\mathrm{a}}$ Conferência de Chefes de Estado e Governo, reunida em Nairobi, no Quênia, em 1981.

\section{4. A Teoria Geracional dos Direitos Humanos e Suas Críticas}

Fruto de um longo processo histórico de reconhecimento, os direitos humanos sofreram acentuadas mutações ao longo do tempo, não apenas no que se refere ao seu conteúdo, mas também em relação à sua titularidade e eficácia. Em razão disso, desenvolveu-se uma fórmula de abordagem do tema que se tornou muito tradicional na doutrina: a teoria das gerações de direitos.

Mencionada teoria foi exposta, pela primeira vez, pelo jurista francês Karel Vasak, em uma Conferência proferida no Instituto Internacional de Direitos Humanos no ano de 1979. Em tal oportunidade, Vasak elaborou um modelo de classificação dos direitos humanos, que levava em consideração não apenas suas características, mas também as etapas históricas relativas à sua afirmação. Com base nisso, dividiu tais direitos em três classes, denominando-as de gerações e, a cada uma delas, associou um dos componentes do lema da Revolução Francesa: liberdade, igualdade e fraternidade. ${ }^{204}$

Os direitos humanos de primeira geração são, assim, denominados de direitos de liberdade. Correspondem àqueles direitos originários do pensamento liberalburguês que constituiu a base ideológica das Revoluções do Século XVIII. Destinam-se, em essência, à demarcação de uma esfera de autonomia do indivíduo frente ao poder do Estado, não pressupondo, dessa forma, uma conduta positiva dos poderes públicos para sua satisfação, mas tão somente uma abstenção, sendo, por isso, também chamados de direitos de cunho negativo. Em geral, são identificados como de primeira geração os direitos à vida, à liberdade (em suas várias dimensões), à propriedade e à igualdade perante a lei,

\footnotetext{
${ }^{204}$ ANDRÉ DE CARVALHO RAMOS, op. cit., p. 82.
} 
bem como, os direitos de participação política, como o direito de voto e a capacidade eleitoral passiva.

A segunda geração associa-se aos direitos sociais e econômicos, que abarcam tanto os direitos fundamentais do trabalhador, como alguns direitos que exigem uma prestação positiva dos poderes públicos, como é o caso dos direitos à saúde, à educação, à previdência social, à assistência social, dentre outros. Como resultado do reconhecimento de que apenas a consagração formal da liberdade e igualdade não era suficiente para garantir seu efetivo gozo a todos os seres humanos, fator que desencadeou o processo de lutas sociais ocorridas no curso do século XIX, tal geração de direitos humanos é marcada pela modificação do papel do Estado, de quem não mais se exige uma abstenção no domínio das relações individuais, mas uma participação ativa na realização da justiça social. Por tais razões, os direitos costumam ser apresentados como de cunho positivo e freqüentemente denominados como direitos de igualdade.

Seguindo a tríade da Revolução Francesa, a doutrina aponta a emergência de uma terceira geração de direitos humanos: os denominados direitos de fraternidade ou de solidariedade. Tais direitos distinguem-se das demais dimensões de direitos humanos pelo fato de se desprenderem, em um primeiro momento, da figura do homem-indivíduo como seu titular, voltando-se à proteção de grupos humanos - família, povo, nação caracterizando-se, desse modo, como direitos de titularidade coletiva ou difusa. A doutrina cita, com maior freqüência, os direitos à paz, à autodeterminação dos povos, ao desenvolvimento, ao meio ambiente, à qualidade de vida, à conservação e utilização do patrimônio histórico e cultural e à comunicação como sendo os direitos humanos de terceira geração. Do ponto de vista de seu reconhecimento histórico, deve-se ressaltar que a maior parte desses direitos foi consagrada no âmbito do processo de internacionalização dos direitos humanos, muito embora cada vez mais a ordem jurídica de vários Estados comecem a incorporá-los em suas Constituições. Cabe finalmente, uma observação quanto à terminologia empregada para designar os direitos dessa dimensão. Para INGO WOLFGANG SARLET, o uso freqüente da expressão "direitos de solidariedade" decorre, de modo especial, da implicação universal ou, no mínimo, transindividual desses direitos, e por exigirem eles esforços e responsabilidades em escala até mesmo mundial para sua efetivação. ${ }^{205}$ Tal advertência é válida, porque, não raro, tem-se associado, por conta de tal nomenclatura, o princípio axiológico da solidariedade (vide abaixo o item 1.5.1, d, deste

${ }^{205}$ Op. cit.,p. p. 58-59. 
capítulo) diretamente a essa dimensão de direitos humanos, esquecendo-se que tal princípio encontra-se, sobretudo, na base dos direitos sociais. ${ }^{206}$

A teoria que subdivide os direitos humanos em gerações tem sido, contudo, alvo de rigorosas e pertinentes críticas. AnTÔNIO Augusto CANÇADo TRINDADE, um dos maiores expoentes da doutrina nacional sobre o assunto, refere-se à "fantasia das chamadas gerações de direitos", revelando sua reprovação à teoria apresentada ao mundo por Karel Vasak. Segundo o autor, trata-se tal teoria de uma visão atomizada ou fragmentada dos direitos humanos no tempo, o que a torna histórica e juridicamente infundada. Nas palavras do insigne jurista tal noção simplista "tem prestado um desserviço ao pensamento mais lúcido a inspirar a evolução do Direito Internacional dos Direitos Humanos"207.

Em primeiro lugar, é necessário esclarecer que os direitos humanos, diferentemente do que a invocação analógica de sucessão geracional parece supor, não se sucedem ou substituem uns aos outros. Pelo contrário, o que se verifica é a acumulação, o fortalecimento e a interação entre os direitos humanos reconhecidos em distintos momentos históricos, fator que revela a natureza complementar e indivisível desses direitos. $^{208}$

Em segundo lugar, é mister ressaltar que, no plano internacional, os direitos sociais começaram a ser afirmados logo após a Primeira Guerra Mundial, por meio das convenções da Organização Internacional do Trabalho, precedendo, em tal esfera, ao próprio reconhecimento dos direitos individuais, que só ocorreu anos mais tarde, após a Segunda Grande Guerra. ${ }^{209} \mathrm{O}$ mencionado fato bem revela a fragilidade da tese das gerações de direitos, que pretende, em última análise, definir, com rigidez, diversas etapas históricas de afirmação dos direitos humanos e relacioná-las, com igual rigor, às diferentes categorias desses direitos, como se o processo histórico fosse simplesmente linear, e não dialético.

\footnotetext{
${ }^{206}$ Além das três gerações de direitos, amplamente consagradas na doutrina, PAULO BonAVIDES, dentre outros autores não menos importantes, defende a existência de uma quarta geração de direitos humanos. Para tal autor esta seria o resultado da chamada globalização dos direitos humanos, que equivaleria à universalização desses direitos no campo institucional. Comporiam essa geração os direitos à democracia direta, à informação e ao pluralismo. In Curso de Direito Constitucional, 14a ed., São Paulo, Malheiros, 2004, p. p. 570-572.

${ }^{207}$ Tratado de Direito Internacional dos Direitos Humanos, Vol. I, Porto Alegre, Sérgio Antonio Fabris, 1997, p. 24.

${ }^{208}$ ANTÔNIO AUGUSTO CANÇADO TRINDADE, op. cit. (Tratado...), p. 25.

${ }^{209}$ ANTÔNIO Augusto CANÇADo TRINDADE, op. cit. (Tratado...), p. 25.
} 
Por derradeiro, a teoria das gerações de direitos, não raro, tem servido como estratagema ideológico destinado a fundamentar um tratamento desigual para a efetivação de determinados direitos ou categorias de direitos. A visão segmentária dos direitos humanos proporcionada por essa tese atende, assim, perfeitamente aos propósitos daqueles que pretendem, de maneira arbitrária, colocar os direitos individuais (chamados de direitos de primeira geração) em posição de prevalência quanto à sua realização, em relação aos demais (sobretudo, em relação aos sociais, econômicos e culturais). Com base nisso, ANTÔNIO AUGUSTO CANÇADO TRINDADE infere que:

\begin{abstract}
(...) a visão fragmentada dos direitos humanos interessa sobretudo aos regimes autoritários, ao autoritarismo sem bandeiras, seja no plano político, seja no plano econômico-social; tal visão tem servido aos interesses dos responsáveis pelos abusos e violações ostensivos de ontem dos direitos políticos e pelas iniqüidades econômico-sociais veladas de hoje. ${ }^{210}$
\end{abstract}

\title{
1. 5. Princípios dos Direitos Humanos
}

Destaca FÁbio Konder Comparato, que "a ordem jurídica forma um sistema dinâmico, um conjunto solidário de elementos criados para determinada finalidade e adaptável às mutações do meio onde atua (...)". ${ }^{211}$ Dentro desse sistema, os direitos humanos acabam por constituir o mais importante microssistema, o qual, como qualquer outro, é regido por princípios e regras gerais que lhe dão coesão e "permitem sempre a correção de rumos, em caso de conflitos internos ou transformações externas". ${ }^{212}$ Segundo

\footnotetext{
${ }^{210}$ Antônio Augusto CançAdo Trindade, Direitos Humanos e Meio Ambiente - Paralelo dos Sistemas de Proteção Internacional, Porto Alegre, Sergio Antonio Fabris, 1993, p. 223. JoRGE LUIZ SOUTO MAIOR e MARCUS ORIONE GONÇALVES CORREIA acrescentam às críticas apresentadas por Cançado Trindade, o argumento de que "a forma como as gerações dos direitos humanos tem sido disposta quase que agrega aos direitos sociais indevidas limitações dispostas pelos direitos individuais - mais especialmente o direito de propriedade, que, no sistema capitalista, passa a ser tido como princípio (princípio da propriedade) e a ser tratado indevidamente e quase que sempre, como sobreprincípio ou postulado fundante do direito constitucional. A unidade política sugere, ainda que o sistema seja capitalista, que, no cotejo dos princípios, pelo menos a base fundante dos valores éticos e, mesmo políticos, da sociedade não possa se remeter a um postulado fundante - a propriedade - que é externa ao próprio homem, sob pena de os valores do direito se deslocarem do homem para elemento que não lhe é necessariamente inerente. Assim, se o direito de propriedade pudesse subjugar todos os demais direitos, passando a ser princípio - e mais sobreprincípio seria possível se deslocar, indevidamente, a proteção do homem (destinatário do direito) para a propriedade (objeto do direito)". In $O$ que é Direito Social? in MARCus ORIONE GONÇAlVES CORREIA (org.), Curso de Direito do Trabalho - Teoria Geral do Direito do Trabalho, vol. I, São Paulo, LTr, 2007, p. 15.

${ }^{211}$ Op. cit. (A Afirmação...), p. p. 61-62.

${ }^{212}$ Op. cit. (A Afirmação...), p. 62.
} 
o citado jurista, tais princípios são de duas ordens, "conforme digam respeito aos valores éticos supremos, ou à lógica estrutural do conjunto". ${ }^{213}$

\section{5. 1. Os Princípios Axiológicos dos Direitos Humanos}

\section{a) A Dignidade da Pessoa Humana}

Mais do que um princípio ético, a dignidade da pessoa humana pode ser considerada como o próprio fundamento dos direitos humanos. Os principais diplomas do pós-guerra, seja no âmbito do Direito Internacional, seja na esfera do Direito Constitucional de diversos países (sobretudo, os do Ocidente), contemplam tal noção. De fato, a Declaração Universal dos Direitos do Homem principia com a afirmação de que "todos os seres humanos nascem livres e iguais, em dignidade e direitos". As Constituições da Alemanha, Itália, Espanha e Portugal, dentre outras, trazem expressa a idéia de que a dignidade humana é a base e o fim de toda a ordem política. Quanto a Constituição brasileira de 1988, esta, de maneira inédita nesse país, coloca a dignidade da pessoa humana como um dos princípios fundamentais da República (art. $1^{\text {o }}$, III) ${ }^{214}$.

Explica Flávia Piovesan que a dignidade da pessoa humana é o ponto de partida e o ponto de chegada de toda a hermenêutica constitucional contemporânea, sendo, por isso, um superprincípio que orienta e confere sentido tanto à ordem jurídica nacional como ao próprio Direito Internacional. ${ }^{215}$

Deflui do exposto, a inquestionável importância que o princípio da dignidade humana tem para a Ciência Jurídica moderna. Contudo, apontar o seu conteúdo não é tarefa simples.

Segundo FÁBIO KONDER COMPARATO, a antropologia filosófica hodierna (pilar de desenvolvimento de toda a teoria fundamental dos direitos humanos) vem estabelecendo, aos poucos, um consenso sobre as características que compõem a dignidade própria e distintiva do homem, quais sejam: "a liberdade como fonte da vida ética, a

\footnotetext{
${ }^{213}$ Op. cit. (A Afirmação...)., p. 62.

${ }^{214}$ A respeito confira-se FÁBIO KONDER COMPARATO, op. cit. (Fundamento...), p. p. 7-8.

${ }^{215}$ FlÁVIA PIOVESAN, op. cit.(Direitos Humanos e o Direito Constitucional...), p. 31.
} 
autoconsciência, a sociabilidade, a historicidade e a unicidade existencial do ser humano". 216

Com extrema precisão e completude, Ingo WolfGAng SARLET apresenta um conceito jurídico da dignidade da pessoa humana como sendo:

(...) a qualidade intrínseca e distintiva reconhecida em cada ser humano que o faz merecedor do mesmo respeito e consideração por parte do Estado e da comunidade, implicando, neste sentido, um complexo de direitos e deveres fundamentais que assegurem a pessoa tanto contra todo e qualquer ato de cunho degradante e desumano, como venham a lhe garantir as condições existenciais mínimas para uma vida saudável, além de propiciar e promover sua participação ativa e co-responsável nos destinos da própria existência e da vida em comunhão com os demais seres humanos. ${ }^{217}$

\section{b) A Liberdade}

Afirma FÁBio Konder COMPARATO que "a liberdade existe como um valor ético em si mesmo, independentemente dos benefícios concretos que a sua fruição pode trazer aos homens. Ela é um atributo essencial do ser humano, distinguindo-o, por isso, de todos os demais seres vivos". 218

O núcleo desse princípio é a idéia de autonomia, ou seja, a submissão de cada indivíduo às normas por ele mesmo criadas. Nesse sentido, uma sociedade é realmente livre quando é regulada pelas regras que ela própria edita e se encontra submetida aos governantes que ela escolhe. No final do século XVIII, entretanto, estabeleceu-se, com a ascensão da burguesia e da ideologia liberal, a distinção entre liberdade pública, com a conotação política de autogoverno, e as liberdades privadas, como mecanismos de defesa do cidadão contra interferências governamentais. Porém a História veio demonstrar a estreita ligação entre essas duas esferas da liberdade. ${ }^{219}$ "A liberdade política sem as liberdades individuais não passa de engodo demagógico de Estados

\footnotetext{
${ }^{216}$ Op. cit. (Fundamento...), p. p. 8-14.

${ }^{217}$ As Dimensões da Dignidade da Pessoa Humana: Uma Compreensão Jurídico Constitucional Aberta e Compatível com os Desafios da Biotecnologia in DANIEL SARMENTo E Flávia PiOVESAN (coord.), Nos Limites da Vida - Aborto, Clonagem Humana e Eutanásia sob a Perspectiva dos Direitos Humanos, Rio de Janeiro, Lúmen Júris, 2007, p. p. 236-237.

${ }^{218}$ Ética - Direito, Moral e Religião no Mundo Moderno, São Paulo, Companhia das Letras, 2006, p. 546.

${ }^{219}$ FÁBIO KONDER COMPARATO, op. cit. (A Afirmação...), p. p. 62-63.
} 
autoritários ou totalitários. E as liberdades individuais, sem efetiva participação política do povo no governo, mal escondem a dominação oligárquica dos mais ricos". 220

\section{c) A Igualdade}

A igualdade traduz a essência da idéia de justiça. Corresponde à noção de que todos os seres humanos, a despeito das múltiplas diferenças culturais e biológicas que os distinguem entre si, são essencialmente iguais. A evolução histórica desse princípio, a exemplo do que ocorreu com a liberdade, deu-se de maneira dicotômica. As revoluções burguesas do século XVIII, que nada mais foram do que uma luta contra privilégios estamentais, fixaram a idéia da igualdade dos indivíduos perante a lei (igualdade formal). Todavia, a Revolução Industrial e a consagração do sistema econômico capitalista abriram uma nova divisão na sociedade, representada, de um lado, pelos detentores do capital e, de outro, pela imensa massa dos alijados da propriedade (os trabalhadores). A partir disso, travou-se, no seio da sociedade, um longo e doloroso processo de lutas que resultou no reconhecimento de que a igualdade formal fundada apenas na concepção individualista burguesa era insuficiente à garantia da dignidade humana.

\section{d) A Solidariedade}

O princípio da solidariedade começou a ser invocado de maneira efetiva pelo movimento socialista, que o empregou como um dever jurídico, a partir do século XIX, ante a percepção da incompletude dos princípios da liberdade e da igualdade, quando tomados sob a concepção liberal-burguesa. A solidariedade relaciona-se à noção de responsabilidade de todos pelas carências ou necessidades de qualquer indivíduo ou grupo social. O fundamento ético desse princípio repousa na idéia de justiça distributiva, entendida como a necessária compensação de bens e vantagens entre as classes sociais, com a socialização dos riscos normais da existência humana. Com esteio nesse princípio, houve o reconhecimento como direitos humanos dos denominados direitos sociais, que se realizam por meio da execução de políticas públicas, com o fim de garantir o amparo e a

\footnotetext{
${ }^{220}$ FÁBio Konder COMPARATO, op. cit. (A Afirmação...), p. 63.
} 
proteção social dos mais fracos e mais pobres, em outros termos, daqueles que não dispõem dos recursos necessários a uma existência digna. ${ }^{221}$

Como bem sintetiza FÁBIo KONDER COMAPARATO:

Os direitos sociais englobam, de um lado, o direito ao trabalho e os diferentes direitos do trabalhador assalariado; de outro lado, o direito à seguridade social (saúde, previdência e assistência social), o direito à educação; e, de modo geral, como se diz no Pacto Internacional sobre Direitos Econômicos, Sociais e Culturais de 1966 (art. 11), 'o direito de toda pessoa a um nível de vida adequado para si próprio e sua família, inclusive à alimentação, vestimenta e moradia adequadas, assim como a uma melhoria contínua de suas condições de vida'. ${ }^{222}$

Finalmente, é com base também na solidariedade, que se tem consagrado a idéia de atribuir à propriedade uma função social. ${ }^{223}$

\subsubsection{Os Princípios Estruturais do Sistema dos Direitos Humanos}

Modernamente, a doutrina tem reconhecido a existência de três princípios estruturais do sistema dos direitos humanos: o princípio da irreversibilidade; o princípio da complementariedade solidária; o princípio da aplicabilidade imediata e da plena eficácia das normas definidoras de direitos fundamentais. ${ }^{224}$

a) O Princípio da Complementariedade Solidária

A Conferência Mundial de Direitos Humanos de 1993 proclamou solenemente o princípio da complementariedade solidária, nos seguintes termos:

Todos os direitos humanos são universais, indivisíveis, interdependentes e inter-relacionados. A comunidade internacional deve tratar dos direitos humanos globalmente, de modo justo e eqüitativo, com o mesmo fundamento e a mesma ênfase.

\footnotetext{
${ }^{221}$ FÁBio Konder COMPARATO, op. cit. (A Afirmação...), p. 64.

${ }^{222}$ Op. cit. (A Afirmação...), p. p. 64-65.

${ }^{223}$ Op. cit.(A Afirmação...), p. 65.

${ }^{224}$ Nesse sentido, conferir FÁBIO Konder Comparato, op. cit. (A Afirmação...), p. 65, INGO WolfGANG SARlet, op. cit., p. 273 e Flávia Piovesan, op. cit. (Direitos Humanos e o Direito Constitucional Internacional...), p. p. 35-36 e 80.
} 
Levando em conta a importância das particularidades nacionais e regionais, bem como os diferentes elementos de base históricos, culturais e religiosos, é dever dos Estados, independentemente de seus sistemas políticos, econômicos e culturais, promover e proteger todos os direitos humanos e as liberdades fundamentais.

A complementariedade solidária é, pois, expressão de quatro características essenciais dos direitos humanos: a universalidade, a indivisibilidade, a interdependência e a inter-relação desses direitos. A universalidade traduz a condição dos direitos humanos pertencerem a todos os indivíduos, diante do reconhecimento indissociável da sua dignidade. Reflete, assim, a tendência de guiar todos os setores da comunidade internacional ao reconhecimento dos referidos direitos e a adoção de mecanismos para a garantia de sua efetividade. A indivisibilidade e seus corolários, a interdependência e a inter-relação dos direitos humanos, atrelam-se à concepção de que os direitos humanos compõem um núcleo, não podendo ser compartimentalizados ou compreendidos separadamente. Além disso, traduzem a noção da impossibilidade de precedência de um direito humano sobre o outro (idéia de que a proteção a um direito humano não é mais importante que a dada a outro).

Em decorrência do princípio da complementariedade solidária, advém, em linhas práticas, a necessidade de se conferir um tratamento global a esses direitos humanos, tendo em vista que a tutela de um deles pode depender da proteção conferida aos demais e vice-versa. Exemplificativamente, não há como se garantir o direito ao trabalho, sem que se garanta o direito à vida. Por outro lado, o direito à vida, se faz pleno, quando igualmente se garante uma série de medidas de proteção ao trabalho, v. g., um salário mínimo compatível com as necessidades básicas do indivíduo, uma limitação da jornada de labor a níveis toleráveis, uma eficaz proteção ao meio ambiente de trabalho, a concessão de descanso semanal remunerado, dentre outras.

Segundo FÁBIO KONDER COMPARATO, “a justificativa desse princípio encontra-se no postulado ontológico de que a essência do ser humano é uma só, não obstante a multiplicidade de diferenças, individuais e sociais, biológicas e culturais, que existem na humanidade". ${ }^{225}$

${ }^{225}$ Op. cit.(A Afirmação...), p. 67. 


\section{b) O Princípio da Irreversibilidade}

O princípio da irreversibilidade dos direitos humanos é também conhecido na doutrina como princípio da irrevocabilidade, princípio da inderrogabilidade ou, finalmente, como princípio da proibição do retrocesso social. Em linhas gerais, sintetiza-se na asserção de que, uma vez reconhecido um direito dessa ordem, ele se incorpora de forma definitiva à consciência ética coletiva, tornando-se irreversível.

A esse mister expõe FÁBIO KONDER COMPARATO:

A consciência ética coletiva (...) amplia-se e aprofunda-se com o evolver da História. A exigência de condições sociais aptas a propiciar a realização de todas as virtualidades do ser humano é, assim, intensificada no tempo, e traduz-se, necessariamente, pela formulação de novos direitos humanos.

É esse movimento histórico de ampliação e aprofundamento que justifica o princípio da irreversibilidade dos direitos já declarados oficialmente, isto é, do conjunto dos direitos fundamentais em vigor. Dado que eles se impõem, pela sua própria natureza, não só aos Poderes Públicos constituídos em cada Estado como a todos os Estados no plano internacional, e até mesmo ao próprio Poder Constituinte, à Organização das Nações Unidas e a todas as organizações regionais de Estados, é juridicamente inválido suprimir direitos fundamentais, por via de novas regras constitucionais ou convenções internacionais. $^{226}$

Esclarece ANDRÉ DE CARVALHO RAMOS que o princípio da proibição do retrocesso encontra-se, hoje, plenamente cristalizado no plano internacional, visto que a maioria dos tratados internacionais tem, como cláusula padrão, "a menção à primazia da norma mais favorável ao indivíduo, impedindo que a interpretação de suas normas possa diminuir a proteção já alcançada”. Além disso, adviria consolidado referido princípio na esfera internacional, também pelas cláusulas de "desenvolvimento progressivo", previstas geralmente nos tratados de direitos humanos sociais. ${ }^{227}$

Para INGO WOLFGANG SARLET, a proibição do retrocesso social está ligada à própria noção de segurança jurídica. Explica o mencionado autor que a idéia de segurança jurídica, por sua vez, enraizou-se no pensamento constitucional contemporâneo como subprincípio concretizador do princípio fundamental e estruturante do Estado de Direito, já

${ }^{226}$ Op. cit.(A Afirmação...), p. p. 65-66.

${ }^{227}$ Op. cit., p. p. 243-244. 
que sua ausência, mesmo em um "governo das leis" pode resultar em despotismo e toda a sorte de iniqüidades. Com base nisso, deduz que a segurança jurídica (e, conseqüentemente, a proibição do retrocesso social) constitui "princípio fundamental da ordem jurídica estatal e, para além desta, da própria ordem jurídica internacional, como dão conta as diversas manifestações deste princípio nos diferentes documentos supranacionais". ${ }^{228}$ E que, além disso, a segurança jurídica

(...) coincide também com uma das mais profundas aspirações do ser humano, viabilizando, mediante a garantia de certa estabilidade das relações jurídicas e da própria ordem jurídica como tal, tanto a elaboração de projetos de vida, bem como a sua realização, de tal sorte que desde logo é perceptível o quanto a idéia de segurança jurídica encontra-se umbilicalmente vinculada também à própria noção de dignidade da pessoa humana. ${ }^{229}$

c) O Princípio da Aplicabilidade Imediata e da Plena Eficácia das Normas Definidoras de Direitos Fundamentais

Esse princípio, reconhecido expressamente na maioria das Constituições de países que colocam os direitos humanos como matrizes éticas de seus sistemas jurídicos ${ }^{230}$, foi também reconhecido pela Carta Constitucional brasileira de $1988 \mathrm{em}$ seu art. $5^{\circ}, \S 1^{\circ}$, que assim expressa: "As normas definidoras dos direitos e garantias fundamentais têm aplicação imediata".

Tal preceptivo, segundo Ingo WOLFGANG SARLET, tem um cunho inequivocamente principiológico, traduzindo uma espécie de mandado de otimização (ou maximização) à eficácia dos direitos fundamentais. ${ }^{231}$ Em igual direção, FLÁVIA PIOVESAN destaca que esse princípio realça a força normativa de todos os preceitos constitucionais referentes a direitos, liberdades e garantias fundamentais e, além disso, prevê um regime jurídico específico a eles endereçado, no sentido de incumbir aos Poderes Públicos

\footnotetext{
${ }^{228}$ Op. cit., p. p. $442-443$.

${ }^{229}$ Op. cit., p. 443.

230 Esclarece FlÁVIA PIOVESAN que o princípio da aplicabilidade imediata foi introduzido no Texto Constitucional de 1988, provavelmente sob o influxo do direito comparado, especialmente, do direito alemão, português e espanhol [op. cit. (Direitos Humanos e o Direito Constitucional Internacional...), p. 35]. No mesmo sentido, INGO WOLFGANG SARLET aponta também a influência do direito alemão e uruguaio (op. cit., p. 273).

${ }^{231}$ Op. cit., p. 284.
} 
conferir-lhes eficácia máxima e imediata. ${ }^{232} \mathrm{Em}$ outros termos, "tal princípio intenta assegurar a força dirigente e vinculante dos direitos e garantias de cunho fundamental, ou seja, objetiva tornar tais direitos prerrogativas diretamente aplicáveis pelos Poderes Legislativo, Executivo e Judiciário". ${ }^{233}$

Igualmente José JOAQuim Gomes CANOTILHO expressa que o sentido fundamental da aplicabilidade direta está em reafirmar que:

(...) os direitos, liberdades, e garantias são regras e princípios jurídicos, imediatamente eficazes e actuais, por via direta da Constituição e não através da auctoritas interpositio do legislador. Não são simples norma normarum mas norma normata, isto é, não são meras normas para a produção de outras normas, mas sim normas directamente reguladoras de relações jurídico-materiais". ${ }^{234}$

E acrescenta:

(...) a aplicação direta não significa apenas que os direitos, liberdades e garantias se aplicam independentemente da intervenção legislativa. Significa também que eles valem directamente contra lei quando esta estabelece restrições em desconformidade com a Constituição. $^{235}$

2. As Convenções da Organização Internacional do Trabalho SOBRE DIREITOS HUMANOS

\subsection{O Problema da Identificação dos Tratados Internacionais de} Direitos Humanos: Perspectivas de Abordagem

A problemática relacionada à identificação dos tratados internacionais de direitos humanos tem-se revelado um ponto extremamente complexo e tormentoso para a Ciência Jurídica. A questão, em si, relaciona-se intimamente à delimitação do conteúdo material dos direitos humanos. Todavia, a literatura especializada nem sempre se ocupa

\footnotetext{
${ }^{232}$ Op. cit. (Direitos Humanos e o Direito Constitucional Internacional...), p. p. 35-36.

${ }^{233}$ Flávia Piovesan, op. cit. (Direitos Humanos e o Direito Constitucional Internacional...), p. 36.

${ }^{234}$ Direito Constitucional e Teoria da Constituição, $4^{\mathrm{a}}$ ed., Coimbra, Almedina, 2000, p. 430.

${ }^{235}$ Op. cit., p. 186.
} 
desse tema, realizando, não raro, uma simples enumeração de um extenso rol de diplomas como sendo instrumentos de tal natureza, sem, contudo, apresentar, com rigor metodológico, os critérios utilizados para a eleição de determinados tratados e, sobretudo, para a exclusão de outros tantos.

Quando se ocupa do assunto, porém, a doutrina costuma subdividir-se em duas diferentes óticas para o enfrentamento do problema: a perspectiva estatal ou constitucional, pela qual os direitos fundamentais são vistos como direitos dos homens em um determinado tempo e lugar; a perspectiva universalista (ou internacionalista), por meio da qual, tais direitos são analisados como pertencentes a todos os homens (ou categoria de homens) em todos os lugares, num certo tempo. ${ }^{236}$

A perspectiva estatal ou constitucional de abordagem da temática dos direitos humanos - ou como preferem seus defensores, dos direitos fundamentais - , parte do pressuposto de que uma conceituação que pretenda abranger de maneira definitiva, completa e abstrata (universal) o conteúdo material desses direitos "está fadada, no mínimo, a um certo grau de dissociação da realidade de cada ordem constitucional individualmente considerada”. ${ }^{237}$ Isso porque o que é fundamental para um Estado pode não ser para outro e mesmo algumas categorias universalmente tidas como fundamentais, tais como, os valores da vida, liberdade, igualdade e dignidade humana, podem sofrer uma valoração distinta em cada Estado, em razão de seu condicionamento à determinada realidade social e cultural. Portanto, um conceito satisfatório somente poderia ser obtido à luz de um ordenamento constitucional concreto. ${ }^{238}$

INGO WOLFGANG SARLET, que adota deliberadamente esse enfoque, elabora um critério bastante sofisticado para a construção de um conceito material dos direitos fundamentais sob o ponto de vista da ordem constitucional brasileira. De acordo com o referido autor, seria possível deduzir diretamente do art. $5^{\circ}, 2^{\circ}$, da Constituição Federal (cláusula de abertura material da Carta Constitucional), ter o sistema jurídico pátrio consagrado, ainda que de maneira implícita, o princípio da equivalência. Por meio desse princípio, podem ser considerados como direitos fundamentais em sentido material todos os direitos que, por seu conteúdo (substância) e importância (relevância de determinada matéria para o sentimento jurídico dominante em dado momento histórico), forem

236 José Carlos VieIRA De Andrade, Os Direitos Fundamentais na Constituição Portuguesa de 1976, Almedina, 1986, p. 11, apud, INGO WOLFGANG SARLET, op. cit., p. 26.

${ }^{237}$ INGO WOLFGANG SARLET, op. cit., p. 90.

${ }^{238}$ INGO WOLFGANG SARLET, op. cit., p. p. 91-92. 
equiparáveis aos constantes do catálogo de direitos expressamente arrolados na Constituição. ${ }^{239}$

Destarte, aqueles tratados internacionais que puderem, em razão de sua substância e relevância, ser comparados aos direitos e garantias fundamentais explícitos no rol constitucional, também deverão ser considerados como autênticos direitos fundamentais. Tal processo comparativo não está desprovido, contudo, de certo grau de subjetividade, na medida em que a avaliação dos critérios da importância e conteúdo dos tratados é, essencialmente, uma operação hermenêutica, dependente, pois, da maior ou menor sensibilidade do intérprete. Todavia, segundo INGO WOLFGANG SARLET, existiriam alguns referenciais para essa análise, concernentes, sobretudo, nos princípios fundamentais da Carta Política brasileira (arts. $1^{\circ}$ a $4^{\circ}$ ), especialmente o da dignidade da pessoa humana, que cumpririam a função de balizas para o processo dedutivo de reconhecimento de direitos fundamentais situados fora do catálogo. ${ }^{240}$

Em contraposição à encimada ótica está a visão universalista de análise da questão. Tal enfoque tem sua origem no movimento de internacionalização dos direitos humanos, consolidado após a Segunda Guerra Mundial. Tendo como marco maior a Declaração Universal de Direitos do Homem de 1948, referido movimento introduz a chamada concepção contemporânea dos direitos humanos, embasada nas características da universalidade e indivisibilidade desses direitos.

Universalidade porque clama pela extensão universal dos direitos humanos, sob a crença de que a condição de pessoa é o requisito único para a titularidade de direitos, considerando o ser humano como um ser essencialmente moral, dotado de unicidade existencial e dignidade. Indivisibilidade porque a garantia de direitos civis e políticos é condição para a observância dos direitos sociais, econômicos e culturais e viceversa. $^{241}$

A perspectiva universalista associa-se intimamente ao próprio surgimento do Direito Internacional dos Direitos Humanos, na medida em que retrata a redefinição do

\footnotetext{
${ }^{239}$ Op. cit., p. 106-109.

${ }^{240}$ Op. cit., p..109-131.

241 FláVIA PIOVESAN, Direitos Humanos e Relações Internacionais: Desafios e Perspectivas Contemporâneas in LÉLIO BENTES CORRÊA E TÁRCIO JOSÉ VIDOTTI (coordenadores), Trabalho Infantil $e$ Direitos Humanos - Homenagem a Oris de Oliveira, São Paulo, LTr, 2005, p.178.
} 
espectro de proteção a esses direitos: substitui-se a idéia de que o resguardo aos direitos humanos seria um problema exclusivamente doméstico, pela noção de que este seria um tema legítimo de interesse de toda a comunidade internacional. Como corolário, emerge um sistema internacional de proteção, integrado por tratados internacionais "que refletem, sobretudo, a consciência contemporânea compartilhada pelos Estados, na medida em que invocam o consenso internacional acerca de parâmetros protetivos mínimos relativos aos direitos humanos (o 'mínimo ético irredutível')". ${ }^{242}$

Para Antônio Augusto CAnÇAdo TRIndade, o Direito Internacional dos Direitos Humanos (e, portanto, a própria perspectiva universalista de enfrentamento do tema) se insurge contra a "seletividade discricionária", ao sustentar que os direitos humanos devam se impor "de igual modo, consoante os mesmos critérios, a todos os países". ${ }^{243}$ Todavia, tal fato não implica a impossibilidade de coexistência entre o sistema internacional de proteção aos direitos humanos e os diversos sistemas normativos nacionais. Em outros termos, citados níveis de proteção não se revelam dicotômicos, mas complementares entre si, uma vez que a existência simultânea de diversos instrumentos jurídicos pode servir ao propósito de ampliar e fortalecer a tutela e promoção desses direitos. $^{244}$

Em conformidade com a ótica universalista, o conteúdo dos direitos humanos seria fruto de um consenso internacional que se foi construindo em torno de determinados valores éticos. Esses, por sua vez, são espelhados, sobretudo, pela Declaração de 1948 e outros instrumentos normativos globais elaborados principalmente no âmbito da Organização das Nações Unidas, dentre os quais avultam como de maior

\footnotetext{
${ }^{242}$ FlÁVIA PIOVESAN, op. cit. (Direitos Humanos e Relações Internacionais...), p. 180.

243 A esse respeito, leciona o citado autor que "O Direito Internacional dos Direitos Humanos se insurge contra a seletividade discricionária, seja no tocante aos destinatários de suas normas, seja em relação às condições de aplicação das mesmas. Quanto aos primeiros, sustenta que os direitos humanos se impõem de igual modo, consoante os mesmo critérios, a todos os países. Quanto às segundas, não admite que se 'escolham' determinados direitos a promover e proteger à exclusão dos demais, adiando a realização destes a um futuro indefinido, geralmente sob o pretexto de alegada falta de recursos materiais. Não admite, em suma, que se sacrifiquem gerações com a promessa vaga e enganosa de só assim se poder começar a construir um 'futuro melhor'. Tais visões fragmentadas no espaço e no tempo, alentadas pelos detentores do poder arbitrário, não se coadunam com o propósito último do Direito Internacional dos Direitos Humanos de assegurar a proteção integral do ser humano em todas as áreas da atividade humana e em todas e quaisquer circunstâncias. Não há justificativa para a seletividade no presente domínio de proteção. Erigido para defender a pessoa humana contra todas as formas de dominação e arbitrariedade, o presente corpus juris de proteção forma um todo harmônico e indivisível". In op. cit. (Tratado...), p. p. 25-26.

${ }^{244}$ FLÁVIA PIOVESAN, op. cit.(Direitos Humanos e Relações Internacionais...), p. p. 180-181.
} 
relevância o Pacto Internacional dos Direitos Civis e Políticos e o Pacto Internacional dos Direitos Econômicos, Sociais e Culturais, ambos de $1966 .^{245}$

\subsection{A Identificação das Convenções Internacionais do Trabalho sobre}

\section{Direitos Humanos}

\subsubsection{Análise Crítica ao Critério Adotado pela Organização Internacional} do Trabalho na Declaração de 1998

O interesse em delimitar, dentre as convenções internacionais do trabalho já existentes, aquelas que consagrariam em seu conteúdo normas de direitos humanos instalou-se, de maneira decisiva, no interior da Organização Internacional do Trabalho, em 1994, quando o Diretor-Geral do Bureau Internacional do Trabalho apresentou seu Relatório à $81^{\mathrm{a}}$ Sessão da Conferência, alertando para a necessidade de se reafirmar, no contexto da globalização econômica, os valores e os meios de ação sobre os quais se assenta a Organização. ${ }^{246}$

A partir desse marco, passou-se, no âmbito da OIT, a serem desenvolvidos trabalhos em regime de cooperação entre o Conselho de Administração e o Bureau Internacional do Trabalho com o intuito de tornar explícito quais seriam os instrumentos convencionais que apresentariam o caráter de normas de direitos humanos.

Os resultados alcançados serviram de base à Reunião de Cúpula sobre Desenvolvimento Social da ONU, ocorrida em Copenhague (Dinamarca), em março de 1995. Em tal ocasião foram estabelecidos certos compromissos internacionais pelos Estados participantes, dentre os quais, um plano de ação para proteção aos direitos básicos dos trabalhadores, arrolados como sendo: a proibição ao trabalho forçado e ao trabalho infantil; a liberdade de associação e organização sindical, bem como, de negociação coletiva; igualdade de remuneração entre homens e mulheres por um trabalho de igual valor, e não discriminação no emprego.

\footnotetext{
${ }^{245}$ Nesse sentido, FlÁVIA PIOVESAN chega a afirmar que "A Declaração de 1948 confere lastro axiológico e unidade valorativa a este campo do Direito [Direito Internacional dos Direitos Humanos] (...)”. In op. cit. Direitos Humanos e Relações Internacionais...), p. 179.

${ }^{246}$ Relatório disponível em: http://www.ilo.org/public/libdoc/ilo/P/09605/09605(1994-81-part-1).pdf. Acesso em 14/10/2008.
} 
O elenco desses mesmos direitos foi, um ano mais tarde, reafirmado no âmbito da Conferência Ministerial da Organização Mundial do Comércio (OMC), que teve lugar em Singapura, em dezembro de 1996.

Lançaram-se, assim, as bases que serviram de inspiração à Organização Internacional do Trabalho para a elaboração da Declaração sobre os Princípios e Direitos Fundamentais no Trabalho, aprovada na $86^{\mathrm{a}}$ Reunião da Conferência Internacional do Trabalho, em 1998, quando se comemorou 50 aniversário da Declaração Universal dos Direitos Humanos.

A Declaração de 1998 teve por objetivo reconhecer explicitamente, por meio de um enunciado solene, o consenso que haveria alcançado a comunidade internacional em torno do significado especial de algumas convenções internacionais do trabalho, as quais refletiriam os princípios que constituem os pilares da Constituição da OIT e que, portanto, mereceriam ser universalmente observadas, independentemente de discussões relacionadas aos níveis de desenvolvimento econômico dos países. Tal consenso seria, segundo a própria OIT, fruto não apenas de conclusões obtidas dentro da Organização, mas também de manifestações expostas fora de seu âmbito, como aquelas ocorridas na Reunião de Cúpula sobre Desenvolvimento Social da ONU e na Conferência Ministerial da OMC. ${ }^{247}$

Dessa forma, foram especificadas pela OIT como fundamentais as seguintes convenções: a Convenção n. 87, sobre Liberdade Sindical e Proteção ao Direito de Sindicalização; a Convenção n. 98, sobre Direito de Sindicalização e de Negociação Coletiva; a Convenção n. 29, sobre Abolição do Trabalho Forçado; a Convenção n. 105, igualmente, sobre Abolição do Trabalho Forçado; a Convenção n. 138, sobre Idade Mínima para Admissão em Emprego; a Convenção n. 182, sobre as Piores Formas de Trabalho Infantil; a Convenção n. 100, sobre Igualdade de Remuneração; e a Convenção n. 111, sobre Discriminação em Matéria de Emprego e Ocupação.

É dever advertir, contudo, que não se pode compreender a Declaração de 1998 como um instrumento que conferiu às convenções supracitadas o caráter de normas

\footnotetext{
247 A respeito, conferir o Informe VII - Examen de una Eventual Declaración de Princípios de la Organización Internacional del Trabajo relativa a los Derechos Fundamentales, y del Mecanismo de Seguimiento Apropriado, Conferência Internacional do Trabalho, 86 ${ }^{\mathrm{a}}$ Reunião, Genebra, junho de 1998 , disponível em http://www.ilo.org/public/spanish/standards/relm/ilc/ilc86/rep-vii.htm; bem como, o terceiro ponto do relatório da $270^{\mathrm{a}}$ reunião do Conselho de Administração, Genebra, novembro de 1997, disponível em http://www.ilo.org/public/spanish/standards/relm/gb/docs/gb270/gb-3-1.htm. Acesso em 14/10/2008.
} 
internacionais de direitos humanos. $\mathrm{O}$ que, na realidade, ela fez foi somente reafirmar a característica da fundamentalidade já existente nessas convenções, como estratégia da Organização Internacional do Trabalho para tornar mais efetiva a aplicação universal dos direitos nela previstos. Tal fato é reconhecido pela própria OIT, que no informe VII da $86^{\mathrm{a}}$ Sessão de sua Conferência, expressa que:

La declaración en cuanto tal no se dirige a establecer el carácter fundamental de determinados derechos. Su preeminencia procede del objeto al que se refieren y del hecho de que ya están reconocidos como fundamentales tanto dentro como fuera de la OIT. En otros términos, los derechos fundamentales no son fundamentales porque la declaración lo diga, sino que la declaración lo dice porque lo son. El objeto específico de la declaración consiste en realidad en promover la aplicación universal de los derechos de los trabajadores que el conjunto de los Miembros de la OIT reconoce como fundamentales a través de una asistencia técnica complementaria para facilitar, entre otros objetivos, la ratificación de los siete convenios fundamentales. (Grifos ausentes no texto original). ${ }^{248}$

Não há como negar que a Declaração sobre Princípios e Direitos Fundamentais no Trabalho tornou-se um eficaz e importante mecanismo de promoção das convenções por ela destacadas. De fato, com sustentáculo nesse documento, a OIT lançou ampla campanha que, em um lapso temporal relativamente curto, já obteve um maciço número de ratificações, além de alcançar importantes resultados no que se refere à aplicação dos princípios e direitos nela reafirmados, mesmo em Estados que não as tenham ratificado. Essa última conquista deve-se, sobretudo, ao seu seguimento, que prevê a intensificação do controle sobre a aplicação dos princípios fundamentais aos membros que ainda não ratificaram alguma das oito convenções a eles relacionadas.

\footnotetext{
248 “A declaração enquanto tal não se destina a estabelecer o caráter fundamental de determinados direitos. Sua premência procede do objeto a que se referem e do fato de que já são reconhecidos como fundamentais tanto dentro como fora da OIT. Em outros termos, os direitos fundamentais não são fundamentais porque a declaração o diga, mas a declaração assim disse, porque os são. O objeto específico da declaração consiste, na realidade, em promover a aplicação universal dos direitos que o conjunto dos membros da Organização Internacional do Trabalho reconhece como fundamentais, através de uma assistência técnica complementar para facilitar, entre outros objetivos, a ratificação das sete convenções fundamentais". (Tradução livre). In Informe VII - Examen de una Eventual Declaración de Princípios de la Organización Internacional del Trabajo relativa a los Derechos Fundamentales, y del Mecanismo de Seguimiento Apropriado, Conferência Internacional do Trabalho, 86 ${ }^{\mathrm{a}}$ Reunião, Genebra, junho de 1998, disponível em http://www.ilo.org/public/spanish/standards/relm/ilc/ilc86/rep-vii.htm. Acesso em 14/10/2008.
} 
Mencionados resultados, sem dúvida, contribuíram para o aumento da credibilidade da Organização Internacional do Trabalho, perante a comunidade internacional, como um dos principais organismos responsáveis pela efetivação dos direitos humanos sociais, o que, por si só, demonstra certo grau de acerto da OIT na elaboração da Declaração de 1998, em termos políticos.

Embora pareça salutar a iniciativa da própria Organização Internacional do Trabalho em tentar definir, dentre toda a sua vasta produção normativa, aqueles instrumentos internacionais que poderiam ser considerados como tratados de direitos humanos, sobretudo, em razão do aparente sucesso obtido - pelo menos do ponto de vista político-estratégico -, conforme já destacado, cumpre esclarecer que a ação empreendida com a referida Declaração não está totalmente alheia a críticas.

Com efeito, sob uma ótica estritamente jurídica, é mister reconhecer que a classificação apresentada na Declaração de Princípios e Direitos Fundamentais é bastante inexata. $^{249}$

Em primeiro lugar, o rol de princípios exposto e, conseqüentemente, de convenções eleitas como fundamentais mostra-se extremamente restrito, deixando de lado uma série de convenções cujo conteúdo não pode ser visto como de importância menor, em termos de proteção aos direitos sociais, do que o daqueles oito instrumentos consagrados pela Declaração. Deveras, como seria possível qualificar como menos fundamentais para a garantia da dignidade humana convenções que tocam diretamente à saúde do trabalhador como, por exemplo, as convenções 155, 161 e 170; ou que visam a proteger o próprio direito ao trabalho, tais como as convenções 122 e 158; ou finalmente aquelas que pretendem assegurar um mínimo de proteção contra os riscos sociais, como as convenções 128 e $157 ?$

Em segundo lugar, não parece crível que o suposto consenso universal em torno da fundamentalidade das convenções internacionais do trabalho aponte apenas para aquelas oito supra referidas. Um simples cotejo das convenções da OIT com a Declaração Universal dos Direitos do Homem de 1948 e com os dois Pactos da ONU de 1966 já é suficiente para revelar que a comunidade internacional reconhece como direitos humanos

\footnotetext{
${ }^{249}$ A inexatidão da classificação feita pela Organização Internacional do Trabalho pode ser explicada pelo fato de que os critérios por ela utilizados não se subsumem a questões jurídicas, sendo levados em consideração também aspectos políticos, econômicos e sociais. A respeito, confira-se, LUCIANE CARDOSO BARZOTTO, op. cit., p. 44.
} 
fundamentais um número bem mais expressivo de direitos, que, por sua vez, guardam correspondência ao conteúdo de diversas outras convenções internacionais do trabalho além daquelas arroladas na Declaração de 1998.

Por derradeiro, não há, de maneira clara, na citada Declaração, a explicitação do critério material utilizado pela Organização Internacional do Trabalho para a eleição dos princípios e convenções considerados fundamentais. $\mathrm{O}$ argumento, por vezes invocado, segundo o qual o conteúdo dessas convenções corresponderia aos princípios que figuram no Preâmbulo da Constituição da OIT e na Declaração da Filadélfia de 1944, o que justificaria a premência de tais instrumentos ${ }^{250}$, não pode ser aceito, uma vez que, em última análise, toda a ação normativa da Organização deriva, em maior ou menor grau, desses mesmos princípios.

De todo o exposto, não há como considerar que a classificação da Organização Internacional do Trabalho seja exaustiva, tampouco adequada como parâmetro a orientar a aplicação dos diferentes regimes de integração das normas internacionais, previstos pela Constituição Federal brasileira.

Ante as insuficiências e impropriedades supra referidas, necessária se mostra a construção de uma proposta classificatória que atenda de maneira mais apropriada aos propósitos desta pesquisa, o que será realizado no subitem seguinte.

2.2.2. Construção de um Critério Adequado para a Identificação das Convenções Internacionais do Trabalho sobre Direitos Humanos

O breve relato histórico realizado no item 1.3. deste capítulo atendeu a um propósito específico: a demonstração de que o Direito do Trabalho surgiu como uma das etapas do longo movimento de afirmação histórica dos direitos humanos.

Como já se referiu, em linhas pretéritas, tem prevalecido no campo doutrinário a concepção que busca enxergar no homem o fundamento derradeiro para os direitos humanos, o que traz como conseqüência o reconhecimento de que a natureza de tais direitos resulta do seu processo histórico de construção. Tal processo, por sua vez, é

${ }^{250}$ Confira-se a respeito o terceiro ponto do relatório da $270^{\text {a }}$ reunião do Conselho de Administração, Genebra, novembro de 1997, disponível em http://www.ilo.org/public/spanish/standards/relm/gb/docs/gb270/ gb-3-1.htm. Acesso em 14/10/2008. 
acompanhado por um movimento de lutas e ações sociais, direcionados ao alcance da dignidade humana. ${ }^{251}$ Nesse sentido, lapidar é a lição de IGNACY SACHS, ao sustentar que:

(...) não se insistirá nunca o bastante sobre o fato de que a ascensão dos direitos é fruto de lutas, que os direitos são conquistados, às vezes, com barricadas, em um processo histórico cheio de vicissitudes, por meio do qual as necessidades e aspirações se articulam em reivindicações e em estandartes de lutas antes de serem reconhecidos como direitos. ${ }^{252}$

No desenrolar desse longo processo de reconhecimento dos direitos humanos, identifica FÁBIO KONDER COMPARATO que:

(...) a compreensão da dignidade suprema da pessoa humana e de seus direitos, no curso da História, tem sido, em grande parte, o fruto da dor física e do sofrimento moral. A cada grande surto de violência, os homens recuam, horrorizados, à vista da ignomínia que afinal se abre claramente diante de seus olhos; e o remorso pelas torturas, as mutilações em massa, os massacres coletivos e as explorações aviltantes faz nascer nas consciências, agora purificadas, a exigência de novas regras de uma vida mais digna para todos. ${ }^{253}$

Com alicerce nessas idéias, evidencia-se, claramente, como o desenvolvimento do Direito do Trabalho constitui-se a mais perfeita tradução da lógica de construção dos direitos humanos.

A Revolução Industrial, ponto de partida da análise histórica do Direito do Trabalho, trouxe como consequiência social a submissão de uma grande massa de trabalhadores a condições de vida extremamente precárias e aviltantes. A violência sobre o proletariado, do início do modelo capitalista, foi um dos momentos mais sombrios da História. Inúmeros foram os atentados contra a dignidade humana praticados naquele período. Sob a lógica do sistema capitalista de produção, que atribui aos bens de capital um valor muito superior ao dos seres humanos, houve a exploração sem precedentes da força de trabalho de homens, mulheres e crianças, marcada pela sujeição dessas pessoas a jornadas excessivas, más condições sanitárias, humilhações e maus-tratos por parte de seus empregadores, em troca de uma vil contraprestação, que mal lhes garantiam o próprio sustento.

${ }^{251}$ FlÁVIA PIOVESAN, op. cit. (Direitos Humanos e o Direito Constitucional Internacional...), p. 108.

${ }^{252}$ Desenvolvimento, Direitos Humanos e Cidadania, in Direitos Humanos no Século XXI, 1998, p. 156, apud, Flávia PiOVESAn, op. cit. (Direitos Humanos e o Direito Constitucional Internacional...), p. 108. ${ }^{253}$ Op. cit.(A Afirmação...), p. 37. 
O esmagamento pela miséria, doença e marginalização, cada vez mais crescente, desse expressivo contingente social fez brotar-lhe os mais profundos sentimentos de inconformismo e indignação. Essa irresignável massa foi adquirindo, com a difusão da ideologia socialista, a consciência de que formava uma classe, passando a se organizar e travar com a burguesia uma série de lutas pela conquista de novos direitos que lhe assegurassem uma existência mais digna.

De maneira gradual, as vitórias do movimento operário foram determinando a afirmação de novos direitos, caracterizados pela sua expressão econômica e social. No início do século $\mathrm{XX}$, tais direitos já haviam se disseminado como valores supremos de garantia da dignidade humana, passando, após a criação da Organização Internacional do Trabalho em 1919, a integrar a consciência ética universal e as bases axiológicas do sistema jurídico de diversos países. No plano da Ciência Jurídica, o reconhecimento de alguns dos mencionados direitos, por meio de uma sólida e sistemática produção normativa, definiu o surgimento de um novo ramo: o Direito do Trabalho, cujo marco emancipatório corresponde, igualmente, ao advento da Organização Internacional do Trabalho, momento em que foram enunciados também os princípios desse segmento jurídico.

Não é difícil sustentar, assim, que a essência de todo o Direito do Trabalho e, conseqüentemente, o conteúdo das principais normas jurídicas que o compõem sejam os direitos humanos. No que tange, especificamente, às convenções da Organização Internacional do Trabalho, tal inferência torna-se ainda mais evidente. A idéia de promoção de uma legislação internacional sócio-laboral ata-se diretamente aos escopos de assegurar bases sólidas para paz mundial e garantir uma existência digna a todos os seres humanos, por meio do combate às injustiças sociais. Toda a produção normativa da OIT pauta-se por essas finalidades e guarda, em maior ou menor grau, pertinência com os grande postulados éticos informadores dos direitos humanos. Deflui de tal fato, que a índole da maioria de suas convenções seja a de tratados internacionais de direitos humanos.

Pode-se objetar, contudo, que a despeito desse embasamento axiológico e finalístico, nem toda a ação normativa da referida Organização redunde necessariamente em normas de direitos humanos, podendo, o conteúdo de determinadas convenções internacionais do trabalho - sobretudo, quando isoladamente consideradas - não condizer diretamente com os valores supremos de preservação da existência humana. 
Nesse contexto, mostra-se de enorme interesse prático a proposição de um critério objetivo que permita demonstrar porque certas convenções podem ser enquadradas como normas internacionais de direitos humanos.

Para tal intento, revela-se inicialmente imprescindível a escolha de uma perspectiva de enfrentamento do problema. Conforme exposto em linhas pretéritas, a doutrina, de maneira majoritária, tende a analisar a temática dos direitos humanos sob duas óticas distintas: uma estatal e outra universal.

Sem pretender tecer um exame aprofundado acerca dos inúmeros acertos e críticas endereçáveis a ambas as perspectivas referidas, matéria que pela sua complexidade escaparia aos objetivos estabelecidos para esta dissertação, é mister reconhecer que, em se tratando de definir a natureza de tratados internacionais e não de normas cingidas à esfera doméstica de determinado Estado, uma perspectiva universalista mostra-se mais apropriada. Além disso, cumpre referir que o mencionado ponto de vista reflete com maior exatidão a concepção moderna dos direitos humanos, vistos como direitos que se impõem de maneira universal e cuja efetivação não se encontra mais restrita à esfera estatal, estando igualmente no centro das preocupações de toda a comunidade internacional. Finalmente, deve-se alertar para o perigo que a adoção de um enfoque puramente estatal poderia redundar, em razão da já destacada "seletividade discricionária" (vide supra o item 2.1. deste capítulo), que mitigaria a proteção integral do homem, em razão de limitações espaciais.

Nada obstante a eleição de um enfoque universalista para a construção do critério classificatório, não se pode deixar de admitir como oportuna a utilização do princípio da equivalência - consagrado no Direito Constitucional de diversos países como mecanismo de aproximação de um conceito material de direitos fundamentais ${ }^{254}$ - como critério válido também para determinar o conteúdo de tratados internacionais de direitos humanos sob uma perspectiva universal, desde que sejam promovidas, por óbvio, as devidas adaptações acarretadas pela transposição, para este prisma, de um critério eminentemente construído perante uma visão estatal de enfrentamento da questão.

Como já referido alhures, pelo princípio da equivalência é possível apreender a nota material da fundamentalidade de determinadas normas jurídicas, não expressamente reconhecidas como fundamentais, pelo cotejo de seu conteúdo (substância) e importância (relevância de determinada matéria para o sentimento jurídico dominante em

${ }^{254}$ Confira-se a respeito INGO WOLFGANG SARLET, op. cit., p. 106-109. 
dado momento histórico), com as normas constantes do catálogo de direitos expressamente arrolados na Constituição de determinado Estado.

Sob uma ótica universalista, o mesmo processo de comparação pode ser feito, mutatis mutandi, adotando-se como referencial aqueles documentos internacionais sob os quais há um incontestável consenso global acerca de seu conteúdo de direitos humanos. Nesse contexto, mostram-se perfeitamente indicados para o cumprimento dessa função de paradigma a Declaração Universal de Direitos do Homem de 1948 - instrumento que sintetiza os direitos que o costume e os princípios jurídicos internacionais consagraram como exigências básicas de respeito à dignidade humana ${ }^{255}$-, assim como o Pacto Internacional sobre Direitos Civis e Políticos e o Pacto Internacional sobre Direitos Econômicos, Sociais e Culturais, adotados pela Organização das Nações Unidas em 1966, que, na realidade, correspondem a um desenvolvimento pormenorizado do conteúdo da Declaração de $1948^{256}$.

Por fim, a pautar, com maior objetividade, a operação hermenêutica de avaliação da substância e importância das convenções da Organização Internacional do Trabalho para fins de equiparação aos direitos previstos na Declaração Universal de 1948 e nos Pactos da ONU de 1966, pode-se lançar mão dos grandes princípios axiológicos dos direitos humanos (dignidade humana, liberdade, igualdade e solidariedade), como referenciais.

Em linhas gerais, são estes os contornos que poderão ser utilizados para uma proposta classificatória viável das convenções da Organização Internacional do Trabalho quanto ao fato de apresentarem um conteúdo próprio de direitos humanos.

\subsubsection{Classificação das Convenções da Organização Internacional do} Trabalho Segundo o Critério Estabelecido

Por uma questão prática, opta-se nesta seção, que tem como objetivo apresentar uma proposta de classificação das convenções internacionais do trabalho segundo os elementos expostos no tópico anterior, realizar uma tabela que permita uma fácil visualização da aplicação do critério da equivalência, com a dimensão universalista sugerida.

\footnotetext{
${ }^{255}$ FÁBio Konder COMPARATO, op. cit. (A Afirmação...), p. 224.

${ }^{256}$ FÁBIO KONDER COMPARATO, op. cit. (A Afirmação...), p. 275.
} 
Nela serão postos, na primeira coluna, os princípios axiológicos dos direitos humanos. Na coluna intermediária, alguns dos postulados expressados na Declaração Universal de Direitos Humanos de 1948 e nos Pactos Internacionais das Nações Unidas de 1966 que servem de patamar comparativo para a aproximação das convenções da Organização Internacional do Trabalho ao conceito material de direitos humanos, distribuídos de acordo com sua maior pertinência a um dos referidos princípios éticos. ${ }^{257}$ Finalmente, na terceira coluna, arrolar-se-ão as convenções que, tendo como referenciais os princípios axiológicos da primeira coluna, sejam equiparáveis, quanto ao seu conteúdo e importância, aos postulados da segunda coluna e que, portanto, podem ser consideradas como tratados internacionais de direitos humanos.

Cumpre advertir que nessa classificação somente serão incluídas aquelas convenções que, além de se encontrarem em vigência internacional, ainda estejam abertas à ratificação pelos países membros da Organização Internacional do Trabalho e não foram deixadas de lado ou retiradas pela Conferência Internacional do Trabalho. ${ }^{258}$

\begin{tabular}{|c|c|c|}
\hline PRINCÍPIOS AXIOLÓGICOS & $\begin{array}{l}\text { POSTULADOS DA DECLARAÇÃO } \\
\text { UNIVERSAL DE } 1948 \text { E DOS } \\
\text { PACTOS INTERNACIONAIS DE } 1966\end{array}$ & $\begin{array}{l}\text { CONVENÇÕES DA ORGANIZAÇÃO } \\
\text { INTERNACIONAL DO TRABALHO } \\
\text { EQUIPARÁVEIS }\end{array}$ \\
\hline \multirow[t]{2}{*}{ LIBERDADE } & $\begin{array}{l}\text { Declaração Universal de } 1948 \text {, art. IV: } \\
\text { "Ninguém será mantido em escravidão ou } \\
\text { servidão; a escravidão e o tráfico de } \\
\text { escravos serão proibidos em todas as suas } \\
\text { formas". Art. XXIII: "Todo ser humano } \\
\text { tem direito (...) à livre escolha de emprego } \\
\text { (...)". } \\
\text { Pacto Internacional de Direitos Civis e } \\
\text { Políticos, art. } 8^{\circ} \text { : "1. Ninguém poderá ser } \\
\text { submetido à escravidão; a escravidão e o } \\
\text { tráfico de escravos, em todas as suas } \\
\text { formas ficam proibidos. } 2 . \text { Ninguém } \\
\text { poderá ser submetido à servidão. } \\
\text { 3. a) ninguém poderá ser submetido a } \\
\text { executar trabalhos forçados ou } \\
\text { obrigatórios". }\end{array}$ & $\begin{array}{l}\text { Convenção n. } 29 \text { sobre trabalho forçado. } \\
\text { Convenção n. } 105 \text { sobre a abolição do } \\
\text { trabalho forçado }\end{array}$ \\
\hline & $\begin{array}{l}\text { Declaração Universal de 1948: art. XX: } \\
\text { "1.Todo ser humano tem direito a } \\
\text { liberdade de reunião e associação pacífica. } \\
\text { 2. Ninguém pode ser obrigado a fazer } \\
\text { parte de uma associação". Art.. XXIII: "4. } \\
\text { Todo ser humano tem direito de organizar }\end{array}$ & \\
\hline
\end{tabular}

${ }^{257}$ Advirta-se, contudo, que a correlação dos direitos arrolados na Declaração Universal de 1948 e nos Pactos de 1966 com determinado princípio ético nem sempre é precisa, já que, boa parte dos referidos direitos têm seu fundamento alicerçado em mais de um desses princípios. Procurar-se-á, no entanto, por meio desta proposta classificatória, identificar o princípio axiológico que mais inspira cada um dos direitos humanos.

${ }^{258}$ Estarão excluídas, consequientemente, dessa análise as convenções: 4, 15, 20, 21, 28, 31, 32, 33, 34, 35, $36,37,38,39,40,41,43,44,46,48,49,50,51,52,54,57,60,61,64,65,66,67,70,72,75,76,86,91,93$, 104, 109, MLC, 187 e 188. Informações disponíveis em: http://www.ilo.org/ilolex/spanish/convdisp1.htm. Acesso em 14/10/2008. 


\begin{tabular}{|c|c|c|}
\hline (LIBERDADE) & 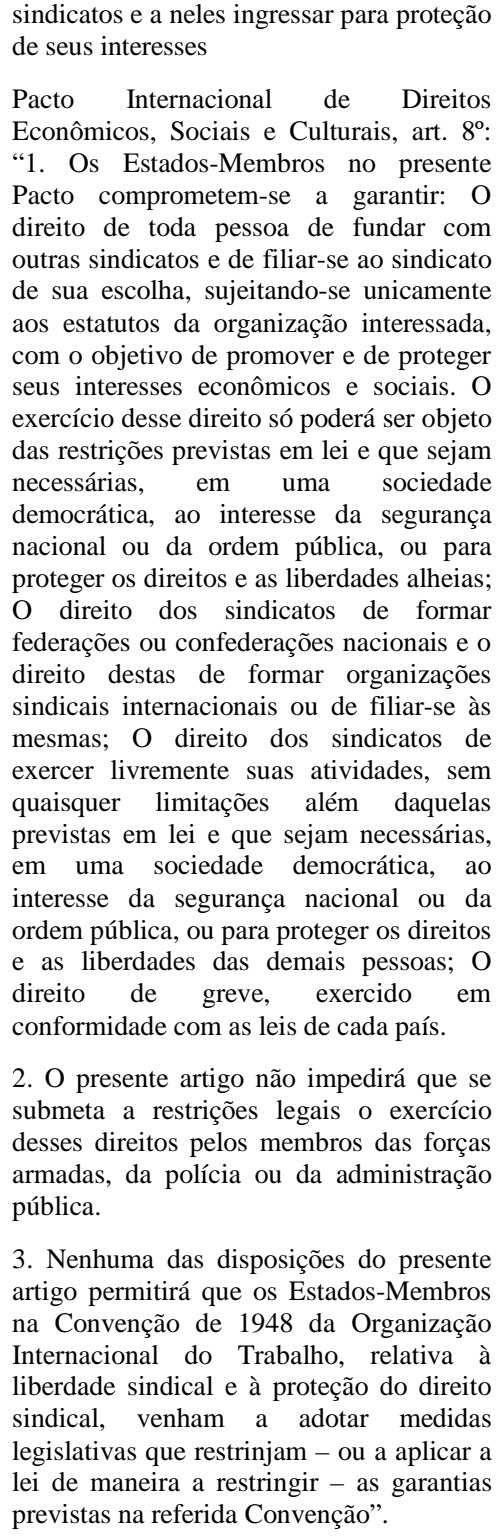 & 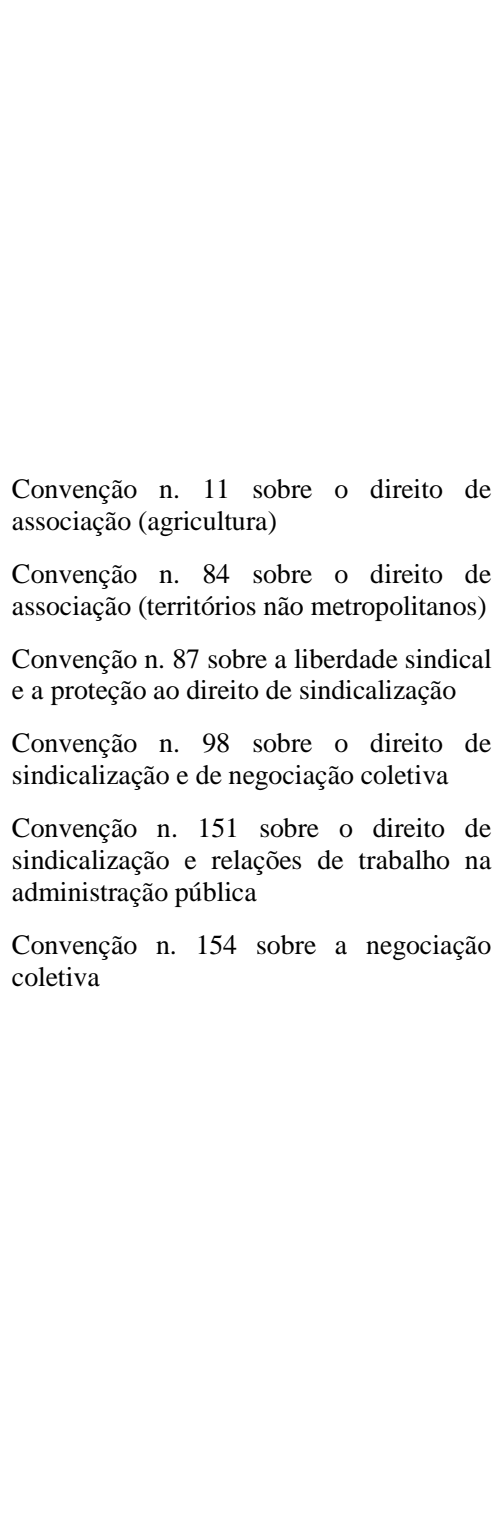 \\
\hline IGUALDADE & $\begin{array}{l}\text { Declaração Universal de 1948: art. VIII: } \\
\text { "Todos são iguais perante a lei e têm } \\
\text { direito, sem qualquer distinção, a igual } \\
\text { proteção da lei. Todos tem direito a igual } \\
\text { proteção contra qualquer discriminação } \\
\text { que viole a presente Declaração e contra } \\
\text { qualquer incitamento a tal discriminação". } \\
\text { Art. XXIII: "2. Todo ser humano, sem } \\
\text { qualquer distinção, tem direito a igual } \\
\text { remuneração por igual trabalho". } \\
\text { Pacto Internacional de Direitos } \\
\text { Econômicos, Sociais e Culturais: art. } 2^{\circ} \text { : } \\
\text { "2. Os Estados-Membros no presente } \\
\text { Pacto comprometem-se a garantir que os } \\
\text { direitos nele enunciados se exercerão sem } \\
\text { discriminação alguma por motivo de raça, } \\
\text { cor, sexo, língua, religião, opinião política } \\
\text { ou de qualquer outra natureza, origem } \\
\text { nacional ou social, situação econômica, } \\
\text { nascimento ou qualquer outra situação. } \\
\text { Art. } 3^{\circ} \text { : "Os Estados-Membros no presente } \\
\text { Pacto comprometem-se a assegurar a } \\
\text { homens e mulheres igualdade no gozo dos } \\
\text { direitos econômicos, sociais e culturais } \\
\text { enumerados no presente Pacto". Art. } 7^{\circ} \text { : }\end{array}$ & 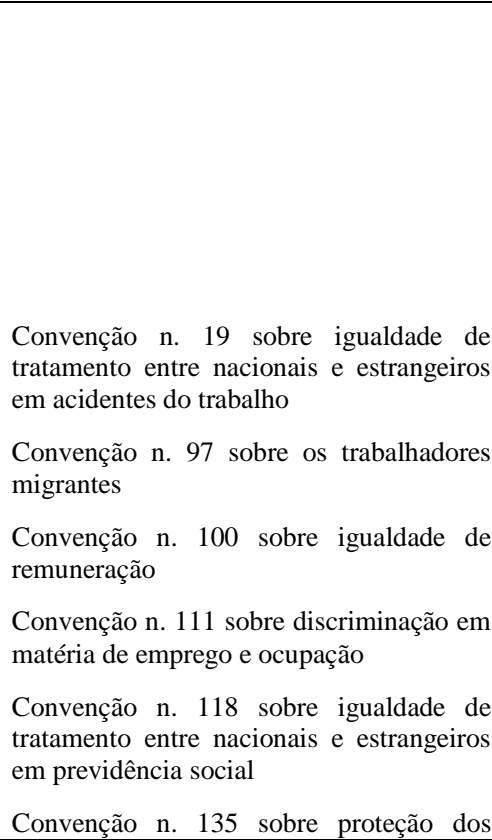 \\
\hline
\end{tabular}




\begin{tabular}{|c|c|c|}
\hline (IGUALDADE) & $\begin{array}{l}\text { "Os Estados-Membros do Presente Pacto } \\
\text { reconhecem o direito de toda pessoa gozar } \\
\text { de condições de trabalho justas e } \\
\text { favoráveis, que assegurem especialmente: } \\
\text { (...) um salário equitativo e uma } \\
\text { remuneração igual por um trabalho de } \\
\text { igual valor, sem qualquer distinção; em } \\
\text { particular as mulheres deverão ter a } \\
\text { garantia de condições de trabalho não } \\
\text { inferiores às dos homens e perceber a } \\
\text { mesma remuneração que eles, por trabalho } \\
\text { igual; (...) igual oportunidade para todos } \\
\text { de serem promovidos, em seu trabalho, à } \\
\text { categoria superior que lhes corresponda, } \\
\text { sem outras considerações que as de tempo, } \\
\text { de trabalho e de capacidade (...)". }\end{array}$ & $\begin{array}{l}\text { representantes dos trabalhadores } \\
\text { Convenção n. } 141 \text { sobre as organizações } \\
\text { dos trabalhadores rurais } \\
\text { Convenção n. } 143 \text { sobre os trabalhadores } \\
\text { migrantes } \\
\text { Convenção n. } 156 \text { sobre os trabalhadores } \\
\text { com responsabilidades familiares }\end{array}$ \\
\hline SOLIDARIEDADE & $\begin{array}{l}\text { Declaração Universal de 1948, art. XXII: } \\
\text { "Todo ser humano, como membro da } \\
\text { sociedade, tem direito à segurança social e } \\
\text { à realização, pelo esforço nacional, pela } \\
\text { cooperação internacional e de acordo com } \\
\text { a organização e recursos de cada Estado, } \\
\text { dos direitos econômicos, sociais e } \\
\text { culturais indispensáveis à sua dignidade e } \\
\text { ao livre desenvolvimento da sua } \\
\text { personalidade". Art. XXV: "1. Todo ser } \\
\text { humano tem direito a um padrão de vida } \\
\text { capaz de assegurar a si e a sua família } \\
\text { saúde e bem estar, inclusive alimentação, } \\
\text { vestuário, habitação, cuidados médicos e } \\
\text { os serviços sociais indispensáveis, e } \\
\text { direito à segurança em caso de } \\
\text { desemprego, doença, invalidez, viuvez, } \\
\text { velhice ou outros casos de perda dos } \\
\text { meios de subsistência fora de seu controle. } \\
\text { Pacto Internacional de Direitos } \\
\text { Econômicos, Sociais e Culturais, art. } 9^{\circ} \text {. } \\
\text { "Os Estados-Membros no presente Pacto } \\
\text { reconhecem o direito de toda pessoa à } \\
\text { previdência social, inclusive ao seguro } \\
\text { social". }\end{array}$ & $\begin{array}{l}\text { Convenção n. } 8 \text { sobre indenizações por } \\
\text { desemprego em caso de naufrágio } \\
\text { Convenção n. } 12 \text { sobre indenização por } \\
\text { acidente de trabalho na agricultura } \\
\text { Convenção n. } 17 \text { sobre indenização por } \\
\text { acidente de trabalho } \\
\text { Convenção n. } 18 \text { sobre as enfermidades } \\
\text { profissionais } \\
\text { Convenção n. } 24 \text { sobre o seguro contra } \\
\text { enfermidades (indústria) } \\
\text { Convenção n. } 25 \text { sobre o seguro contra } \\
\text { enfermidades (agricultura) } \\
\text { Convenção n. } 42 \text { sobre indenização por } \\
\text { enfermidade profissional } \\
\text { Convenção n. } 55 \text { sobre as obrigações do } \\
\text { armador em caso de enfermidade ou } \\
\text { acidentes dos marítimos } \\
\text { Convenção n. } 56 \text { sobre o seguro contra } \\
\text { enfermidade dos marítimos } \\
\text { Convenção n. } 71 \text { sobre as pensões dos } \\
\text { marítimos } \\
\text { Convenção n. } 102 \text { sobre normas mínimas } \\
\text { da seguridade social } \\
\text { Convenção n. } 121 \text { sobre as prestações em } \\
\text { caso acidente de trabalho e } \\
\text { enfermidades profissionais } \\
\text { Convenção n. } 128 \text { sobre as prestações de } \\
\text { invalidez, velhice e sobreviventes } \\
\text { Convenção n. } 130 \text { sobre assistência } \\
\text { médica e prestações monetárias em caso } \\
\text { de enfermidade } \\
\text { Convenção n. } 157 \text { sobre preservação dos } \\
\text { direitos em matéria de seguridade social } \\
\text { Convenção n. } 159 \text { sobre readaptação } \\
\text { profissional e emprego (pessoas inválidas) } \\
\text { Convenção n. } 165 \text { sobre seguridade social } \\
\text { dos marítimos }\end{array}$ \\
\hline & $\begin{array}{l}\text { Declaração Universal de 1948, art. XXV: } \\
\text { "2. A maternidade e a infância têm direito } \\
\text { a cuidados e assistência especiais (...)". } \\
\text { Pacto Internacional de Direitos } \\
\text { Econômicos, Sociais e Culturais, art. 10: } \\
\text { "Os Estados-membros no presente Pacto } \\
\text { Internacional reconhecem que: (...) Deve- } \\
\text { se conceder proteção especial às mães por } \\
\text { um período de tempo razoável antes e }\end{array}$ & 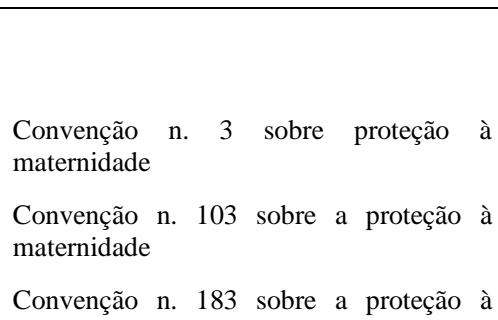 \\
\hline
\end{tabular}




\begin{tabular}{|c|c|c|}
\hline (SOLIDARIEDADE) & $\begin{array}{l}\text { Declaração Universal de 1948, art. XXV: } \\
\text { "2. A maternidade e } \text { a infância têm direito } \\
\text { a cuidados e assistência especiais (...)". } \\
\text { Pacto Internacional de Direitos } \\
\text { Econômicos, Sociais e Culturais, art. 10: } \\
\text { "Os Estados-membros no presente Pacto } \\
\text { reconhecem que: (...) Deve-se adotar } \\
\text { medidas especiais de proteção e } \\
\text { assistência em prol de todas as crianças e } \\
\text { adolescentes, sem distinção alguma por } \\
\text { motivo de filiação ou qualquer outra } \\
\text { condição. Deve-se proteger as crianças e } \\
\text { adolescentes contra a exploração } \\
\text { econômica e social. O emprego de } \\
\text { crianças e adolescentes, em trabalho que } \\
\text { lhes seja nocivo à moral e à saúde, ou que } \\
\text { lhes faça correr perigo de vida, ou ainda } \\
\text { que lhes venha prejudicar o } \\
\text { desenvolvimento normal, será punido por } \\
\text { lei. Os Estados devem também estabelecer } \\
\text { limites de idade, sob os quais fique } \\
\text { proibido e punido por lei o emprego } \\
\text { assalariado da mão-de-obra infantill." } \\
\text { Pacto Internacional de Direitos Civis e } \\
\text { Políticos, art. 24: "1. Toda criança terá } \\
\text { direito, sem discriminação alguma por } \\
\text { motivo de cor, sexo, língua, religião, } \\
\text { origem nacional ou social, situação } \\
\text { econômica ou nascimento, às medidas de } \\
\text { proteção que a sua condição de menor } \\
\text { requer por parte de sua família, da } \\
\text { sociedade e do Estado". }\end{array}$ & $\begin{array}{l}\text { Convenção n. } 5 \text { sobre a idade mínima } \\
\text { (indústria) } \\
\text { Convenção n. } 6 \text { sobre trabalho noturno dos } \\
\text { menores (indústria) } \\
\text { Convenção n. } 7 \text { sobre a idade mínima } \\
\text { (trabalho marítimo) } \\
\text { Convenção n. } 10 \text { sobre a idade mínima } \\
\text { (agricultura) } \\
\text { Convenção n. } 16 \text { sobre exame médico dos } \\
\text { menores (trabalho marítimo) } \\
\text { Convenção n. } 58 \text { sobre a idade mínima } \\
\text { (trabalho marítimo) } \\
\text { Convenção n. } 59 \text { sobre a idade mínima } \\
\text { (indústria) } \\
\text { Convenção n. } 77 \text { sobre o exame médico } \\
\text { dos menores (indústria) } \\
\text { Convenção n. } 78 \text { sobre o exame médico } \\
\text { dos menores (trabalhos não industriais) } \\
\text { Convenção n. } 77 \text { sobre o trabalho noturno } \\
\text { dos menores (trabalho não industriais) } \\
\text { Convenção n. } 90 \text { sobre trabalho noturno } \\
\text { dos menores (indústria) } \\
\text { Convenção n. } 112 \text { sobre a idade mínima } \\
\text { (pescadores) } \\
\text { Convenção n. } 123 \text { sobre a idade mínima } \\
\text { (trabalhos subterrâneos) } \\
\text { Convenção n. } 124 \text { sobre o exame médico } \\
\text { dos menores (trabalhos subterrâneos) } \\
\text { Convenção n. } 138 \text { sobre idade mínima } \\
\text { Convenção n. } 182 \text { sobre as piores formas } \\
\text { de trabalho infantil }\end{array}$ \\
\hline DIGNIDADE DA PESSOA HUMANA & $\begin{array}{l}\text { Declaração Universal de } 1948 \text {, art. XXIII: } \\
\text { "3. Todo homem que trabalha tem direito } \\
\text { a uma remuneração justa e satisfatória, que } \\
\text { lhe assegure, assim como à sua família, } \\
\text { uma existência compatível com a } \\
\text { dignidade humana, e a que se } \\
\text { acrescentarão, se necessário, outros meios } \\
\text { de proteção social". } \\
\text { Pacto Internacional de Direitos } \\
\text { Econômicos, Sociais e Culturais, art. } 7^{\circ} \text {, } \\
\text { "Os Estados-membros no presente Pacto } \\
\text { reconhecem o direito de toda pessoa de } \\
\text { gozar de condições de trabalho justas e } \\
\text { favoráveis, que assegurem especialmente: } \\
\text { Uma remuneração que proporcione. no } \\
\text { mínimo, a todos os trabalhadores: (...) uma } \\
\text { existência decente para eles e suas } \\
\text { famílias, em conformidade com as } \\
\text { disposições do presente Pacto (...)". Art. }\end{array}$ & $\begin{array}{l}\text { Convenção n. } 26 \text { sobre os métodos para a } \\
\text { fixação de salários mínimos } \\
\text { Convenção n. } 95 \text { sobre a proteção ao } \\
\text { salário } \\
\text { Convenção n. } 99 \text { sobre os métodos para a } \\
\text { fixação dos salários mínimos (agricultura) } \\
\text { Convenção n. } 131 \text { sobre a fixação de } \\
\text { salários mínimos }\end{array}$ \\
\hline
\end{tabular}




\begin{tabular}{|c|c|c|}
\hline & $\begin{array}{l}\text { 11: "1. Os Estados-partes no presente } \\
\text { Pacto reconhecem o direito de toda pessoa } \\
\text { a um nível de vida adequado para si } \\
\text { próprio e para sua família, inclusive à } \\
\text { alimentação, vestimenta e moradia } \\
\text { adequadas, assim como uma melhoria } \\
\text { contínua de suas condições de vida. Os } \\
\text { Estados-partes tomarão medida } \\
\text { apropriadas para assegurar a consecução } \\
\text { desse direito, reconhecendo, nesse sentido, } \\
\text { a importância essencial da cooperação } \\
\text { internacional fundada no livre } \\
\text { consentimento". }\end{array}$ & $\begin{array}{l}\text { Convenção n. } 173 \text { sobre a proteção dos } \\
\text { créditos trabalhistas em caso de } \\
\text { insolvência do empregador }\end{array}$ \\
\hline (DIGNIDADE DA PESSOA HUMANA) & $\begin{array}{l}\text { Declaração Universal de 1948, } \\
\text { Art. III: "Todo ser humano tem direito à } \\
\text { vida, à liberdade e à segurança pessoal". } \\
\text { Art. XXIII: "1. Todo ser humano tem } \\
\text { direito (...) a condições justas e favoráveis } \\
\text { de trabalho (...)". } \\
\text { Pacto Internacional de Direitos Civis e } \\
\text { Políticos, } \\
\text { Art. 1: "O direito à vida é inerente à } \\
\text { pessoal humana. Este direito deverá ser } \\
\text { protegido pelas leis. (...)". } \\
\text { Internacional } \quad \text { de Direitos } \\
\text { Pacto } \\
\text { Econômicos, Sociais e Culturais, } \\
\text { Art. 7: "Os Estados-Membros no presente } \\
\text { Pacto reconhecem o direito de toda pessoa } \\
\text { de gozar de condições de trabalho justas e } \\
\text { favoráveis, que assegurem especialmente: } \\
\text { (...) Condições de trabalho seguras e } \\
\text { higiênicas". } \\
\text { Art. 12: "1. Os Estados-partes no presente } \\
\text { Pacto reconhecem o direito de toda pessoa } \\
\text { de desfrutar o mais elevado nível de saúde } \\
\text { física e mental. } \\
\text { 2. As medidas que os Estados-partes no } \\
\text { presente Pacto deverão adotar, com o fim } \\
\text { de assegurar o pleno exercício desse } \\
\text { direito, incluirão as medidas que se façam } \\
\text { necessárias para assegurar: (...) } \\
\text { A melhoria de todos os aspectos de } \\
\text { higiene do trabalho e do meio ambiente. } \\
\text { A prevenção e o tratamento das doenças }\end{array}$ & 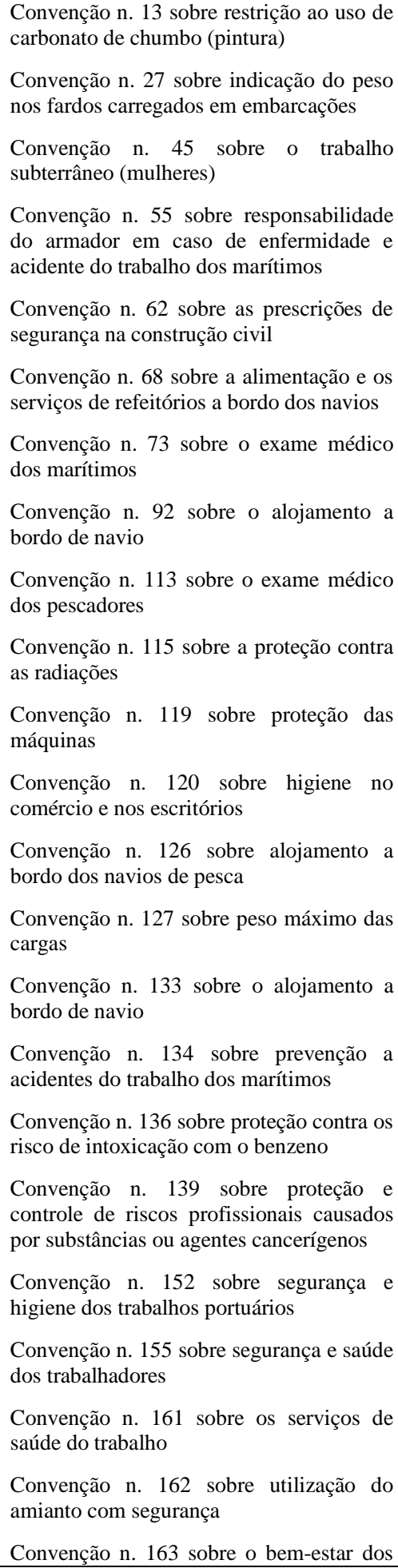 \\
\hline
\end{tabular}




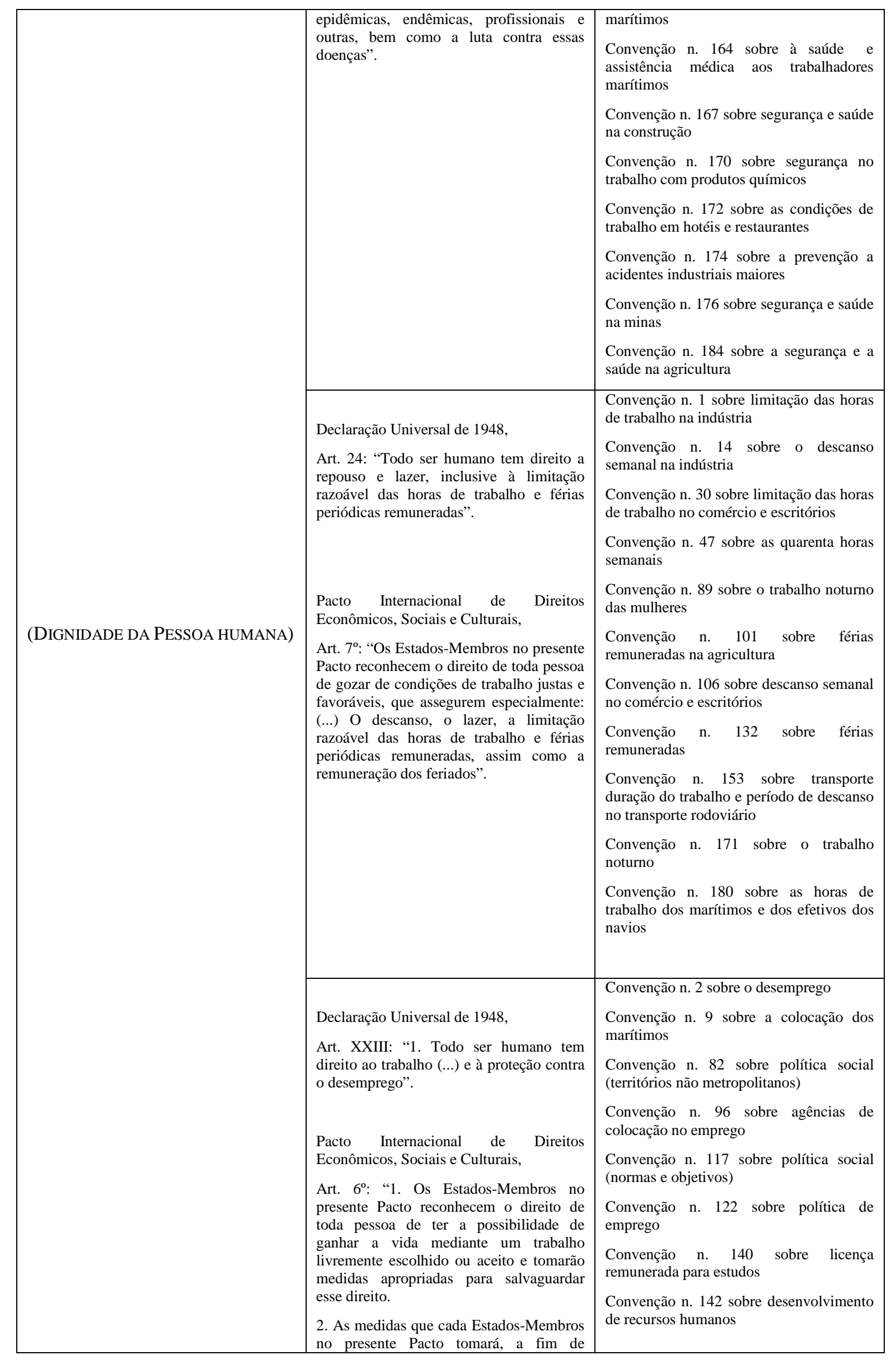




\begin{tabular}{|c|c|c|}
\hline \multirow{2}{*}{ (DIGNIDADE DA PESSOA HUMANA) } & $\begin{array}{l}\text { assegurar o pleno exercício desse direito, } \\
\text { deverão incluir a orientação e a formação } \\
\text { técnica e profissional, a elaboração de } \\
\text { programas, normas técnicas apropriadas } \\
\text { para assegurar um desenvolvimento } \\
\text { econômico, social e cultural constante e o } \\
\text { pleno emprego produtivo em condições } \\
\text { que salvaguardem aos indivíduos o gozo } \\
\text { das liberdades políticas e econômicas } \\
\text { fundamentais". }\end{array}$ & $\begin{array}{l}\text { Convenção n. } 145 \text { sobre a continuidade no } \\
\text { emprego do marítimo } \\
\text { Convenção n. } 158 \text { sobre o término da } \\
\text { relação de emprego por iniciativa do } \\
\text { empregador } \\
\text { Convenção n. } 168 \text { sobre o fomento do } \\
\text { emprego e a proteção contra o desemprego } \\
\text { Convenção n. } 179 \text { sobre a contratação e a } \\
\text { colocação dos marítimos } \\
\text { Convenção n. } 181 \text { sobre as agências } \\
\text { privadas de emprego }\end{array}$ \\
\hline & 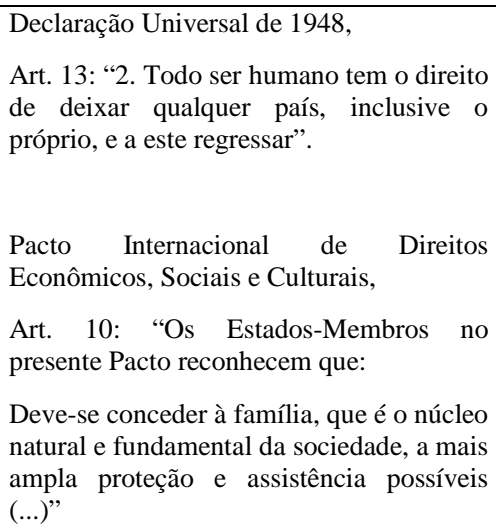 & $\begin{array}{l}\text { Convenção n. 23. sobre a repatriação do } \\
\text { marítimo } \\
\text { Convenção n. } 166 \text { sobre a repatriação do } \\
\text { marítimo }\end{array}$ \\
\hline
\end{tabular}

Ao lado das convenções arroladas nessa tabela, existem outras com o mesmo grau de importância, mas cujo conteúdo, em razão de sua grande abrangência, é equiparável a mais do que uma das classes de preceitos paradigmas transcritos, sendo, para os efeitos dessa classificação, também consideradas como convenções de direitos humanos. Por uma opção metodológica, ao invés de elencá-las por mais de uma vez na tabela supra, prefere-se apontá-las em apartado. São elas:

Convenção n. 81 sobre a inspeção do trabalho

Convenção n. 85 sobre a inspeção do trabalho

Convenção n. 94 sobre as cláusulas de trabalho em contratos celebrados com autoridades públicas

Convenção n. 107 sobre populações indígenas e tribais

Convenção n. 110 sobre as plantações

Convenção n. 129 sobre a inspeção do trabalho na agricultura

Convenção n. 137 sobre o trabalho portuário

Convenção n. 147 sobre normas mínimas da marinha mercante 
Convenção n. 149 sobre o pessoal de enfermaria

Convenção n. 150 sobre a administração do trabalho

Convenção n. 169 sobre povos indígenas e tribais

Convenção n. 175 sobre trabalho em tempo parcial

Convenção n. 177 sobre trabalho em domicílio

Convenção n. 178 sobre inspeção do trabalho marítimo

Finalmente, cumpre advertir que, com base nesta proposta classificatória, não foram enquadradas como de direitos humanos apenas as seguintes Convenções:

Convenção n. 22 sobre o contrato de engajamento do marítimo

Convenção n. 69 sobre o certificado de aptidão de cozinheiros de navio

Convenção n. 74 sobre o certificado de marinheiro preferente

Convenção n. 108 sobre documentos de identidade dos marítimos

Convenção n. 116 sobre a revisão dos artigos finais

Convenção n. 125 sobre o certificado de competência dos pescadores

Convenção n. 144 sobre consulta tripartite

Convenção n. 160 sobre estatísticas do trabalho

Convenção n. 185 sobre documentos de identidade dos marítimos 


\section{CAPÍTULO IV - AS CONVENÇÕES INTERNACIONAIS DO TRABALHO NA ORDEM JURÍDICA NACIONAL}

\section{As Relações entre o Direito Internacional E O Direito}

\section{INTERNO}

\subsection{Teoria Dualista}

O primeiro estudo sistemático sobre a questão do relacionamento entre Direito Internacional e Direito interno foi realizado pelo jurista alemão Carl Heinrich Triepel, em 1899, em sua obra Volkerrecht und Landesrecht, na qual desenvolveu as bases da teoria dualista. ${ }^{259}$

A teoria ganhou grande repercussão, sendo endossada, no começo do século XX, por juristas como Dionisio Anzilotti e Lassa Francisc Lawrence Openheim, dentre outros. Todavia, atribui-se ao monista Alfred von Verdross, a cunhagem da expressão "dualismo", que a realizou em 1914, época em que se iniciaram os primeiros trabalhos críticos à teoria de Triepel. $^{260}$

De acordo com os adeptos dessa concepção, o Direito Internacional e o Direito de cada Estado corresponderiam a sistemas de normas diferentes, independentes e isolados uns dos outros. Isso porque as matérias, os sujeitos, os fundamentos e a estrutura de cada um deles não seriam os mesmos.

Destarte, enquanto o Direito Internacional encontraria seu fundamento na vontade comum dos Estados (Vereimbarung), seu objeto seria a regência das relações entre aqueles e sua estrutura estaria fundada em bases coordenativas, o Direito interno teria seu fundamento exclusivamente na vontade soberana e unilateral do Estado, seu objeto seria a disciplina das relações entre as pessoas estabelecidas no território estatal e sua estrutura baseada na idéia de subordinação. ${ }^{261}$

\footnotetext{
${ }^{259}$ A respeito, confira-se CElso D. DE Albuquerque Mello, op. cit., p. 49, MirTô FragA, o Conflito entre Tratado Internacional e Norma de Direito Interno - Estudo Analítico da Situação do Tratadona Ordem Jurídica Brasileira, Rio de Janeiro, Forense, 1998, p. 4 e VALÉRIO DE OLIVEIRA MAZZUOLI, A Influência dos Tratados de Direitos Humanos no Direito Interno, disponível no site http://jus2.uol.com.br/doutrina/ texto.asp?id=1608. Acesso em 14/10/2008.

${ }^{260}$ Celso D. De AlbuQuerque Mello, op. cit., p. 50.

${ }^{261}$ SAUlo José CASAli BAHIA, Tratados Internacionais no Direito Brasileiro, Rio de Janeiro, Forense, 2000, p. 72.
} 
Como conseqüência dessa perspectiva, jamais haveria conflito entre o Direito Internacional e o Direito interno, porquanto ambas as ordens, por possuírem diferentes esferas de atuação, caminhariam em paralelo. Não haveria, portanto, que se cogitar jamais em interferência ou em primazia de um sobre o outro.

A corrente dualista foi obviamente construída em um período em que o homem (indivíduo) não era considerado um verdadeiro sujeito do Direito Internacional.

Como bem leciona Celso D. De Albuquerque Mello, no século XIX começou a existir entre os internacionalistas uma "reação contra a subjetividade do indivíduo". Neste período, segundo o autor, predominou a noção de uma soberania absoluta do Estado, surgindo, no Direito Internacional, o que já foi denominado de "aristocracia de Estados". O indivíduo somente atingiria o mundo jurídico internacional através do Estado. Justamente em tal época surgiram as teorias negadoras da personalidade internacional do homem, pelas quais se afirmou que apenas o Estado seria sujeito do Direito Internacional, uma vez que esse ramo da Ciência Jurídica seria produto da vontade estatal. O indivíduo, por sua vez, seria sujeito apenas do Direito Interno. ${ }^{262}$

No século XX, porém, o Direito Internacional volta o seu foco novamente para o homem. O desenvolvimento da proteção internacional dos direitos humanos, que encontra na Organização Internacional do Trabalho um dos seus pilares, determinou a superação das teses que defendiam o monopólio do Estado sobre as relações internacionais. A partir daí, consolidou-se, na doutrina internacionalista, a noção de que o homem também seria sujeito de direito no campo internacional.

A esse respeito, expõe PedRo B. DE Abreu Dallari que:

(...) o dualismo é reflexo claro de um Direito Internacional Público no qual predominavam normas de natureza eminentemente contratual, fixadoras de regras políticas de convivência entre Estados soberanos - como, por exemplo, aquelas voltadas ao estabelecimento de acordos de delimitação de fronteiras e de alianças militares ofensivas e defensivas. Ainda eram incipientes, nesses primórdios do século $\mathrm{XX}$, os tratados de natureza marcadamente normativa, que depois passaram a prosperar, voltados à adoção de regras jurídicas uniformizadoras de padrões de conduta a serem observados pelos indivíduos e pessoas jurídicas de direito privado subordinados à soberania dos respectivos Estados contratantes no plano internacional. ${ }^{263}$

${ }^{262}$ Op. cit., p. 416.

${ }^{263}$ Constituição e Tratados Internacionais, São Paulo, Saraiva, 2003, p. 9. 
Com base em tais ponderações, algumas críticas podem ser dirigidas à teoria dualista $^{264}$, sendo talvez, a mais contundente delas a que afirma estar mencionada concepção alicerçada em uma premissa que se revelou, mais tarde, totalmente falsa: a de que o homem não seria sujeito das relações internacionais, mas apenas os Estados.

Não por acaso, os atuais defensores do dualismo não mais o procuram fundamentar em uma pretensa diferença existente entre os sujeitos da ordem internacional e da ordem interna e, portanto, numa distinção também da matéria tratada por cada um desses sistemas. ${ }^{265}$, mas apenas na circunstância deles se apoiarem em duas normas fundamentais diferentes. ${ }^{266}$ De acordo com eles, tal fato, por si só, já seria suficiente para concluir que as normas internacionais e as normas internas encontram seus respectivos fundamentos de validade em âmbitos distintos. Por essa razão, a aplicação da disciplina prevista em um tratado na esfera das relações desenvolvidas internamente em um Estado apenas teria lugar se este criasse, em seu sistema jurídico, uma norma com igual conteúdo.

Nesse sentido, conclui Pedro B. De Abreu Dallari que:

(...) sob a ótica dualista, pode-se falar de recepção do Direito Internacional Público pelo direito interno, mas não de integração entre os dois sistemas normativos, na medida em que, do Direito Internacional Público ao qual o Estado se encontra comprometido, emanam tão-somente diretrizes de natureza política endereçadas às instituições responsáveis pela produção das normas de direito interno. ${ }^{267}$

Na trilha desse raciocínio, ARNALDO SÜSSEKIND explica que mediante a adoção dessa teoria, a ratificação de um tratado internacional não transforma o seu conteúdo em jus receptum, gerando apenas, para o respectivo Estado, a obrigação de adotar, mediante leis próprias, as disposições do instrumento internacional. ${ }^{268}$

\footnotetext{
${ }^{264}$ Na lição de Celso D. DE AlbuQuerque Mello, "é o dualismo passível de uma série de críticas: a) o homem é também sujeito internacional, uma vez que tem direitos e deveres outorgados diretamente pela ordem internacional; b) o direito não é produto da vontade nem de um Estado, nem de vários Estados. $\mathrm{O}$ voluntarismo é insuficiente para explicar a obrigatoriedade do costume internacional; c) Kelsen observa que coordenar é subordinar a uma terceira ordem; assim sendo, a diferença entre as duas ordens não é de natureza, mas de estrutura, isto é, uma simples 'diferença de grau'; d) o DI consuetudinário é normalmente aplicado pelos tribunais internos sem que haja qualquer transformação ou incorporação; e) quanto à escola italiana, que sustenta que o DI se dirige apenas ao Estado e não ao seu direito interno, podemos endossar a opinião de Rolando Quadri, que observa não ser 'possível dissociar o Estado do seu ordenamento"'. In $o p$. cit., p. 50.

${ }^{265}$ Nesse sentido, confira-se Celso D. De AlbuQuerque Mello, p. p. 416-417.

${ }^{266}$ Hans Kelsen, Teoria Pura do Direito, trad. port. de João Baptista Machado, São Paulo, Martins Fontes, 1996, p. 364.

${ }^{267}$ Op. cit., p. 9.

${ }^{268}$ Op. cit. (Direito Internacional...), p. p. 61-62.
} 


\subsection{Teoria Monista}

A concepção monista propõe a plena integração do Direito interno com o Direito Internacional, estando em sua essência a idéia de unidade entre ambas as ordens jurídicas. Segundo Hildebrando ACCiOly, que claramente segue essa teoria, "em princípio, o direito é um só, quer se apresente nas relações de um Estado, quer nas relações internacionais". 269

Como conseqüência dessa perspectiva, não existiria uma relação de autonomia, mas de interdependência entre a ordem jurídica internacional e a nacional, razão pela qual seria lícito concluir que a ratificação do tratado por um Estado importaria a incorporação de suas normas à respectiva legislação interna e não meramente a emanação de uma diretriz de natureza política aos órgãos responsáveis pela elaboração das leis no plano interno.

Essa teoria, por sua própria essência, traz ínsita a preocupação com a questão de potenciais conflitos entre os tratados e a ordem jurídica nacional, subdividindose em duas correntes distintas, conforme a primazia atribuída ao Direito interno (monismo nacionalista) ou ao Direito Internacional (monismo internacionalista).

\subsubsection{O Monismo Nacionalista}

O monismo nacionalista tem suas raízes na filosofia de Hegel e Spinoza, segundo a qual o Estado seria detentor de uma soberania absoluta, não estando, pois, sujeito a nenhum sistema jurídico que não tenha emanado de sua própria vontade. ${ }^{270}$ Conseqüentemente, o fundamento de validade do Direito Internacional estaria ancorado na ordem jurídica interna. Assim, o Direito Internacional vigoraria em um determinado Estado apenas quando este o reconhecesse como vinculante em relação a si, sendo reduzido, portanto, a um simples direito estatal externo.

Tal reconhecimento, conforme ensina HANS KELSEN, poderia "operar-se expressamente por um ato de legislação ou do governo, ou tacitamente, pela efetiva

\footnotetext{
${ }^{269}$ Manual de Direito Internacional Público, $10^{a}$ ed., São Paulo, Saraiva, 1973, p. 5.

${ }^{270}$ Celso D. De Albuquerque Mello, p. 51 e Valério de Oliveira MazzUOli, op. cit. (A Influência...).
} 
aplicação das normas do Direito internacional, pela conclusão de convênios internacionais, pelo respeito das imunidades estatuídas pelo Direito internacional, etc". 271

No cerne de tal concepção assenta-se, desse modo, a idéia do primado da ordem jurídica interna sobre a ordem jurídica internacional ou, em outros termos, a aceitação da soberania do Estado como pressuposição de uma ordem normativa suprema, cuja validade não decorre de nenhuma ordem superior, e que, por esta mesma razão, confere ao Direito Internacional o seu fundamento de validade. ${ }^{272}$

Como conseqüências do acolhimento dessa vertente, podem advir importantes inferências em relação à questão da hierarquia que as normas de Direito Internacional deverão ocupar no sistema jurídico de determinado país.

De fato, se, por essa doutrina, o vigor do Direito Internacional é determinado em relação a um Estado pela sua própria ordem interna, é lícito que se conclua que as normas jurídicas internacionais para tal Estado não possam possuir um status hierárquico superior ao de sua própria Constituição.

Com efeito, as normas de um ordenamento jurídico nacional são dispostas em ordem hierárquica, por meio de uma construção escalonada, em que as regras situadas em um patamar superior conferem o fundamento de validade àquelas que se situam abaixo delas. O ápice dessa estrutura corresponde à norma fundamental. Esta, por sua vez, é uma norma pressuposta (hipotética) que constitui o poder constituinte originário e impõe a todos o dever de obediência às normas constitucionais por ele emanadas. A Constituição, enquanto norma concreta, encontra-se, dessa forma, no topo da hierarquia das normas de um ordenamento jurídico nacional.

Destarte, com base nessa teoria, é possível apenas que as normas internacionais, quando incorporadas, revistam-se, quanto ao critério hierárquico, de um caráter constitucional ou infraconstitucional, conforme o poder constituinte lhes atribua esta ou aquela característica, mas jamais superiores à Constituição do país.

A doutrina, contudo, aponta diversas críticas a esse segmento do monismo. A mais relevante delas é a que enxerga na referida corrente a própria negação da existência do Direito Internacional, uma vez que este nada mais seria do que um direito interno que os Estados aplicariam na sua vida internacional. Além disso, caso a validade dos tratados repousasse nas normas constitucionais que estabelecem o seu modo de conclusão, toda a alteração operada numa ordem constitucional, por meio de um processo revolucionário,

\footnotetext{
${ }^{271}$ HANS KELSEN, op. cit., p. 370.

${ }^{272}$ HANS KeLSEN, op. cit., p. p. $370-373$.
} 
deveria determinar a caducidade de todos os instrumentos internacionais concluídos sob a vigência do regime anterior. Todavia, na prática internacional, em razão do princípio da continuidade ou identidade do Estado, isso nunca ocorre. ${ }^{273}$

\subsubsection{O Monismo Internacionalista}

A corrente do monismo internacionalista foi desenvolvida, principalmente, pela chamada escola de Viena, da qual faziam parte Hans Kelsen, Alfred von Verdross e Kunz, bem como, pela escola realista francesa, cujos principais expoentes eram Georges Scelle, Duguit e Politis. ${ }^{274}$

Tal concepção parte da premissa de que a ordem jurídica internacional encontra seu fundamento de validade não no Direito interno, mas em uma norma fundamental internacional. Esta, segundo HANS KELSEN,

(...) como genuína norma fundamental, não é uma norma posta, mas uma norma pressuposta. Ela representa o pressuposto sob o qual o chamado Direito internacional geral, isto é, as normas globalmente eficazes, que regulam a conduta de todos os Estados entre si, são consideradas como normas jurídicas que vinculam os Estados. Estas normas são criadas pela via de um costume que é constituído pela conduta efetiva dos Estados, isto é, pela conduta dos indivíduos que, de acordo com as ordens jurídicas estaduais, funcionam como governo. $^{275}$

Esta vertente do monismo baseia-se na idéia de que a "unicidade da ordem jurídica decorre do primado do Direito Internacional, sendo que as ordens jurídicas internas a ele devem se ajustar". ${ }^{276}$ Para HAROLDO VALLADÃO, a primazia da norma internacional corresponde "à realidade da organização jurídica da humanidade, como fonte original, objetiva e única decorrendo ou do renascido direito natural ou da imperiosidade da vida social". 277 Já VICENTE MAROTTA RANGEL, assevera que tal superioridade tem por fundamento "a noção de unidade e solidariedade do gênero humano" e "deflui

${ }^{273}$ Celso D. De Albuquerque Mello, op. cit., p. 51.

${ }^{274}$ MIRTÔ FRAGA, op. cit., p. 8.

275 Op. cit., p. 240.

276 ARi Possidônio Beltran, Direito do Trabalho e Direitos Fundamentais, São Paulo, LTr, 2002, p.138.

${ }^{277}$ Direito Internacional Privado, vol. I, $5^{\text {a }}$ ed., Rio de Janeiro, 1980, p.53. 
normalmente de princípios jurídicos fundamentais, tal como o pacta sunt servanda e o voluntas civitatis maximae est servanda". ${ }^{278}$

O primeiro impacto dessa teoria é a redefinição do próprio conceito de soberania dos Estados, que não pode mais ser entendida de forma absoluta, porquanto dependente da ordem internacional. Como salienta HANS KELSEN,

(...) se as ordens jurídicas estaduais ou as comunidades jurídicas por elas constituídas, os Estados, são designadas como 'soberanas', isso significa simplesmente que elas se encontram subordinadas à ordem jurídica internacional, que elas são jurídicointernacionalmente imediatas. ${ }^{279}$

Outro resultado é o deslocamento do problema da norma fundamental de um Estado para o plano internacional. De maneira mediata, a norma fundamental internacional é que conferirá o fundamento último de vigência à ordem nacional e não uma norma hipotética que empresta validade à Constituição de um Estado. ${ }^{280}$

O monismo internacionalista, por sua vez, apresenta duas vertentes: a radical e a moderada.

Para a linha radical, jamais seria admissível um conflito entre um preceito de Direito interno com outro de Direito Internacional, uma vez que este, sob o prisma da hierarquia das normas, seria sempre superior àquele. Assim, numa hipótese de colisão aparente entre ambas, a norma interna não poderia ser considerada válida, preservando-se a unidade do sistema jurídico. Haveria, portanto, uma supraconstitucionalidade das normas internacionais que condicionaria a ordem jurídica estatal.

A crítica normalmente endereçada à concepção radical é a de que, ao menosprezar a vontade constituinte, ela negaria a "existência e a autonomia do próprio direito interno, como se nada existisse da soberania do Estado e como se, de fato, os aplicadores do direito interno não tivessem de efetivamente cumprir o comando constitucional". Em outros termos, ela consideraria como um mero fato todo um ordenamento jurídico, com validade própria, sendo, sob esse aspecto, inadmissível. ${ }^{281}$

\footnotetext{
${ }^{278}$ Os Conflitos entre o Direito Interno e os Tratados Internacionais in Boletim da Sociedade Brasileira de Direito Internacional, $\mathrm{n}^{\circ} \mathrm{s} 45$ e 46, Rio de Janeiro, p. p. 54-55, apud ARNALDO SÜSSEKIND, op. cit. (Direito Internacional...), p. 62.

${ }^{279}$ Op. cit., p. 377.

${ }^{280}$ HANS KELSENS, op. cit. p. 240.

${ }^{281}$ SAUlo José CASAli BAHIA, op. cit., p. 77.
} 
A tese radical foi sustentada por Hans Kelsen inicialmente. Entretanto, por influência de Alfred von Verdross, o primeiro passou também a adotar uma posição moderada, segundo a qual o conflito entre uma norma de Direito Internacional com outra de Direito interno seria admissível, gerando, porém, a responsabilidade internacional do Estado. Em outros termos, uma norma interna cujo conteúdo colidisse com outra de Direito Internacional permaneceria válida internamente, embora, fosse considerada inválida perante a ordem internacional, o que permitiria ao Estado prejudicado o direito de iniciar um processo de responsabilidade internacional. ${ }^{282}$

Como se percebe, a solução moderada visou resolver a questão relativa à falta de autonomia do Direito interno. No entanto, trouxe como consequiência um novo problema, muito bem apreendido por SAULO JOSÉ CASALI BAHIA, segundo quem:

(...) o monismo internacionalista moderado, ao intentar acolher a validade do direito interno, em que pese ainda considerá-lo como um fato ilícito perante o direito internacional, termina por fazer suas conclusões coincidirem exatamente com aquelas dos dualistas, ao admitir uma dupla esfera de validade, interna e internacional. ${ }^{283}$

\subsection{Posição Adotada pelo Brasil}

A prática internacional tem demonstrado que as concepções supra descritas revelam-se apenas como modelos teóricos, mas não como verdades universais, dado que, na realidade, a Constituição de cada Estado é quem tem determinado como se dão as relações entre o Direito Internacional e a ordem jurídica interna. ${ }^{284}$

No caso brasileiro, contudo, não há na Lei Maior uma opção expressa por uma ou outra das teorias, cabendo à doutrina e à jurisprudência nacionais, a partir da análise sistemática de alguns dispositivos constitucionais, revelar qual seria a posição adotada.

\footnotetext{
${ }^{282}$ Celso D. DE AlbuQuerQue Mello, op. cit., p. 52.

283 Op. cit., p. 77.

284 A respeito já observou JosÉ FRANCISCO REZEK que: "Descentralizada, a sociedade internacional contemporânea vê cada um de seus integrantes ditar, no que lhe concerne, as regras de composição entre o direito internacional e o de produção doméstica" In Direito Internacional Público: Curso Elementar, $5^{\mathrm{a}}$ ed., São Paulo, Saraiva, 1995, p. 103.
} 
No plano jurisprudencial tem prevalecido atualmente o entendimento consubstanciado pelo Supremo Tribunal Federal no acórdão prolatado na ADIn - 1.480, segundo o qual o Brasil teria se filiado à corrente dualista (em uma modalidade, porém, que a Suprema Corte denominou de moderada). Nesse sentido, merece ser transcrito o seguinte excerto:

Não se pode desconhecer, na linha da concepção dualista - que supõe a pluralidade, em caráter autônomo, de ordens normativas distintas e independentes e que sustenta a existência de limites definidos entre o direito interno e o direito externo -, que se impõe, para efeito de absorção das cláusulas constantes de tratados internacionais, um ato de formal recepção (que não se confunde com a mera ratificação) praticado segundo as regras inscritas no ordenamento positivo do Estado subscritor.

Impõe-se, neste ponto, fazer uma observação necessária: a visão dualista, precisamente por enfatizar que a ordem internacional e o ordenamento interno qualificamse como ordens normativas independentes, entende necessário que o conteúdo normativo do ato internacional - para revestir-se de aplicabilidade no plano interno - deve ser transformado, mediante formalidade estabelecida no sistema constitucional, em norma jurídica interna, não bastando, em consequiência, na perspectiva do regime instituído na Carta Política do Brasil, a mera e só ratificação do tratado, consoante pretendem os adeptos da concepção monista.

Não obstante tais considerações, impende destacar que o tema concernente à definição do momento a partir do qual as normas internacionais tornam-se vinculantes no plano interno excede, em nosso sistema jurídico, à mera discussão acadêmica em torno dos princípios que regem o monismo e o dualismo, pois cabe à Constituição da República - e a esta, somente - disciplinar a questão pertinente à vigência doméstica dos tratados internacionais.

Sob tal perspectiva, o sistema constitucional brasileiro - que não exige a edição de lei para efeito de incorporação do ato internacional ao direito interno (visão dualista extremada) - satisfaz-se, para efeito de executoriedade doméstica dos tratados internacionais, com a adoção de iter procedimental que compreende a aprovação congressional e a promulgação executiva do texto convencional (visão dualista moderada). ${ }^{285}$

${ }^{285}$ ADIn 1.408-DF, rel. Min. CELSO DE MELLO, julgado em 4.9.1997, publicado no DJU em 18.5.2001. 
A tese defendida pelo Supremo Tribunal Federal encontrou eco na doutrina nacional. Para SAUlo José CASAli BAHIA, no sistema jurídico brasileiro a vigência internacional e a vigência interna do tratado não seriam simultâneas, visto que esta última dependeria de um ato normativo posterior à ratificação, concernente no decreto que lhe dá publicidade. $^{286}$

Em sentido contrário, sustenta-se que o decreto de execução expedido pelo Presidente da República não traduz a adoção pelo sistema jurídico nacional da teoria dualista de integração das normas de Direito Internacional. Isso porque, mencionado decreto serviria apenas para a promulgação e a publicação do tratado ratificado na órbita interna. Os atos de promulgação e publicação da lei (em sentido amplo), consoante as lições de JOSÉ AFONSO DA SILVA, não teriam natureza legislativa e, em rigor, não integrariam o próprio processo legislativo. A promulgação não passaria, assim, de mera comunicação do conteúdo de uma norma já existente aos seus destinatários e a publicação o instrumento daquela, ${ }^{287}$ sendo, portanto, totalmente imprecisa a noção de que não é o tratado ou convenção internacional que produz efeitos internos, mas o decreto expedido pelo Presidente da República. ${ }^{288}$

Trata-se da corrente da doutrina brasileira que afirma ter o ordenamento pátrio abraçado a teoria monista. A esse respeito, ARNALDO SÜSSEKIND é enfático ao reconhecer que "a Lex Fundamentalis de 1988 adotou a teoria monista, em virtude da qual (...) o tratado ratificado complementa, altera ou revoga o direito interno, desde que se trate de norma self-executing e já esteja em vigor na órbita internacional."289 Também categoricamente assevera MIRTÔ FRAGA que "nosso direito aderiu à teoria monista, ao determinar a obrigatoriedade de aplicação do tratado, sem exigir expressa ou implicitamente, que um ato legislativo interno disponha sobre matéria naquele contida". ${ }^{290}$ Seguindo a mesma linha, porém, admitindo que a matéria não é tão evidente na ordem jurídica pátria, CARlos RoBERTO HUSEK afirma que “o conjunto das normas

\footnotetext{
${ }^{286}$ Op. cit., p. 81.

${ }^{287}$ Curso de Direito Constitucional Positivo, $28^{\mathrm{a}}$ ed., São Paulo, Malheiros, 2006, p. p. 528-529.

${ }^{288}$ Em cima disso JOSÉ FRANCISCO REZEK explica que "os tratados vigem internamente com sua roupagem original de tratados e, nessa qualidade, e sob esse exato título, revogam direito anterior de produção interna, tal como faria uma lei ordinária superveniente". In op. cit. (Direito dos Tratados...), p. 383.

289 ARNALDO SÜSSEKIND, op. cit.(Direito Internacional...), p. 68.

${ }^{290}$ Op. cit., p. 113.
} 
constitucionais, se bem analisadas, nos revelará, assim cremos, um país com tendência monista (...)". 291

Finalmente, há uma terceira tese doutrinária que afirma ter o sistema jurídico brasileiro adotado uma teoria mista: monista em relação aos tratados de direitos humanos e dualista em relação aos demais. ${ }^{292}$

O fundamento para essa posição repousa no princípio da aplicabilidade imediata das normas definidoras de direitos fundamentais, consagrada explicitamente no art. $5^{\circ}, \S 1^{\circ}$, da Constituição Federal, que permitiria uma exegese válida no sentido de que a ratificação de um tratado de direitos humanos, por si só, bastaria para a irradiação de seus efeitos na órbita jurídica interna, dispensando-se o decreto de execução. Tal fato caracterizaria a opção pelo monismo em matéria de recepção de instrumentos internacionais sobre direitos humanos.

Em relação ao restante dos tratados, a formalidade do decreto continuaria obrigatória, não havendo, no mais, nenhuma discrepância em relação à posição do Supremo Tribunal Federal no tocante ao reconhecimento de um dualismo moderado.

Observa-se de todo o exposto que as querelas existentes acerca da opção brasileira por uma das teorias que procuram explicar a relação existente entre Direito Internacional e Direito interno não se prendem exatamente à questão da primazia de um sobre o outro, concentrando-se apenas sobre o aspecto da recepção formal da norma internacional.

A explicação para tanto se encontra na própria evolução teórica das correntes dualista e monista, que conduziu a uma inexorável aproximação entre ambas.

Como já observado alhures, o dualismo moderno não mais parte do pressuposto de que a ordem internacional disciplinaria relações jurídicas distintas daquelas reguladas por uma ordem estatal. Pelo contrário, atualmente há o reconhecimento por parte dos dualistas de que o Direito Internacional também se volta à produção de instrumentos aplicáveis às relações havidas entre indivíduos dentro de um Estado. Nesse ponto, torna-se inevitável a admissão de que o sistema nacional e a ordem internacional se condicionem e

${ }^{291}$ Curso de Direito Internacional Público, $3^{\text {a }}$ ed., São Paulo, LTr, 2000, p. 31.

${ }^{292}$ Esta posição é defendida por FláVIA PIOVESAN, op. cit. (Direitos Humanos e o Direito Constitucional Internacional...), p. 86 e VALÉRIO DE OLIVEIRA MAZZUOLI, Direito Internacional - Tratados e Direitos Humanos Fundamentais na Ordem Jurídica Brasileira, Rio de Janeiro, América Jurídica, 2001, p. p. 55-56, dentre outros. 
se influenciem mutuamente, muito embora se mantenha a idéia de que haveria uma dualidade de âmbitos de validade das normas.

No que concerne aos monistas, dificilmente se observa, atualmente, a defesa de alguma das concepções tidas como extremadas (monismo nacionalista ou monismo internacionalista radical), prevalecendo, na Ciência Jurídica, a tese que apregoa uma vertente mais moderada para o monismo internacionalista. Tal concepção pode ser sintetizada aproveitando-se as lições de HILDEBRANDO ACCIOLY, para quem não se deve confundir a superioridade do Direito Internacional em relação ao Direito interno, como uma espécie de subordinação deste àquele ou como uma delegação de normas do primeiro ao segundo. Trata-se, na realidade de uma relação de coordenação entre ambas as ordens, com o reconhecimento, em vista do bem comum e sob a égide do Direito objetivo, da primazia do Direito Internacional, o que, porém, não impede a existência de normas de direito interno contrárias à ordem internacional, trazendo como consequiência apenas a responsabilização do Estado nessa última esfera. ${ }^{293}$

É inegável, portanto, que as correntes monista e dualista absorveram muito das críticas que uma endereçava à outra e as diferenças existentes entre elas já não apresentam a mesma intensidade exibida à época em que foram concebidas. Atualmente, as distinções são praticamente irrelevantes, sendo possível concluir que a escolha por uma ou outra teoria baseia-se mais em fatores ideológicos, do que propriamente científicos.

\section{A InCORPORAÇÃo das CONVENÇÕES INTERNACIONAIS do TrabalHo} À ORDEM JURÍDICA BRASILEIRA

\subsection{Considerações Preliminares}

O procedimento de vinculação do Estado brasileiro aos tratados internacionais, encontra sua disciplina básica nos arts. 49, I, e 84, VIII, da Constituição Federal, in verbis:

Art. 49. É da competência exclusiva do Congresso Nacional:

293 Tratado de Direito Internacional Público, vol. I, $2^{\mathrm{a}}$ ed., Rio de Janeiro, Ministério das Relações Exteriores, 1956, p. p. 45-46. 
I - resolver definitivamente sobre tratados, acordos ou atos internacionais que acarretem encargos ou compromissos gravosos a patrimônio nacional;"

Art. 84. Compete privativamente ao Presidente da República:

(...)

VIII - celebrar tratados, convenções e atos internacionais sujeitos a referendo do Congresso

Nacional;

Apesar da pouca clareza e aparentes contradições desses artigos, que revelam a má técnica legislativa acerca do tratamento da matéria ${ }^{294}$, é possível inferir, sem maiores esforços, que se trata de uma decisão que depende da conjugação de vontades do Poder Executivo e do Poder Legislativo. ${ }^{295}$

Se de um lado parece evidente a existência desse concurso entre Executivo e Legislativo, nem tão claro é o papel desempenhado por cada um desses Poderes em tal processo, o que tem suscitado muita confusão no plano doutrinário.

De maneira equivocada, significativa parte da doutrina sustenta que o Congresso Nacional é o órgão encarregado de ratificar os tratados internacionais. ${ }^{296} \mathrm{~A}$

\footnotetext{
294 A doutrina constitucionalista e internacionalista nacionais tecem duras críticas à redação dos artigos supracitados. A esse respeito, JOÃO GRANDINO RODAS chega a afirmar que tal redação manteve-se fiel à nossa má tradição constitucional na matéria. In Tratados Internacionais, São Paulo, Revista dos Tribunais, 1991, p. 12, apud VALÉRIO DE OlIVEIRA MAZZUOLI, op. cit. (Direito Internacional...), p. 160. PEDRO B. DE ABREU DALlARI também é enfático nas críticas, ao expor que "as poucas e esparsas normas formais relacionadas ao tema não permitem que a regra brasileira de regência da matéria detenha os atributos de clareza, precisão, harmonia e exaustão, essenciais à configuração de um verdadeiro sistema, mesmo porque nem sequer são convergentes”. In op. cit., p. 45. FLÁVIA PIOVESAN igualmente critica o tratamento constitucional dispensado à questão, ao afirmar que a Constituição Federal "traz uma sistemática lacunosa, falha e imperfeita, ao não prever, por exemplo, prazo para que o Presidente da República encaminhe ao Congresso o tratado por ele assinado (emblemático é o caso da Convenção de Viena sobre o Direito dos Tratados, que foi assinada em 1969 e encaminhada à apreciação do Congresso apenas em 1992). Não há ainda previsão de prazo para que o Congresso aprecie o tratado assinado e nem mesmo previsão de prazo para que o Presidente da República ratifique o tratado, se aprovado pelo Congresso". In Temas de Direitos Humanos, São Paulo, Max Limonad, 1998, p. 71.

${ }^{295}$ Informa VALÉRIO DE OLIVEIRA MAZZUOLI que a regra da colaboração entre o Executivo e o Legislativo na conclusão dos tratados não constitui nenhuma novidade no sistema normativo do país, estando presente em todas as Constituições brasileiras, à exceção da Constituição do Império de 1824 e da Carta de 1937. In op. cit. (Direito Internacional...), p. p. 153-154.

${ }^{296}$ Nesse sentido, confira-se MANOEL GONÇALVES FERREIRA FILHO, Comentários à Constituição Brasileira de 1988, Vol. 1, $2^{\text {a }}$ ed., São Paulo, Saraiva, 1997, p. 296; AMAURI MASCARO NASCIMENTO, Iniciação ao Direito do Trabalho, $28^{\mathrm{a}}$ ed., São Paulo, LTr, 2002, p. 134; AlEXANDRE DE MoRAES, Direitos Humanos Fundamentais - Teoria Geral, Comentários aos arts. $1^{o}$ a $5^{\circ}$ da Constituição da República Federativa do Brasil, Doutrina e Jurisprudência, $3^{\text {a }}$ ed., São Paulo, Atlas, 2000, p. 304; CARLOS WeIS, Direitos Humanos Contemporâneos, São Paulo, Malheiros, 1999, p. 26.
} 
conclusão in casu advém da incorreta interpretação da expressão "resolver definitivamente", inserta no inc. I do art. 49 da Constituição da República. ${ }^{297}$

Como bem pondera VALÉRIO DE OLIVEIRA MAZZUOLI, a expressão em tela deve ser cotejada com a competência do Chefe do Executivo para celebrar tratados, convenções e atos internacionais, estabelecida no art. 84, VIII, da Constituição. ${ }^{298}$ Não basta, portanto, para que se compreenda perfeitamente o sistema de conclusão dos tratados adotado pelo Brasil, que se faça uma interpretação isolada de cada um dos dispositivos constitucionais acima transcritos, sendo imprescindível uma exegese sistemática e teleológica, que permita harmonizar ambos os preceitos e, ao mesmo tempo, integrá-los a outros princípios existentes na Constituição quanto à definição de competências entre os Poderes Constituídos.

Com efeito, a condução da política externa do país é incumbência acometida ao Poder Executivo e mais especificamente ao Presidente da República. Deveras, é ele o responsável pela dinâmica das relações exteriores e pela defesa da nação no cenário internacional, sendo titular de todas as etapas do processo de conclusão dos tratados, inclusive aquela relativa ao consentimento final do Estado em obrigar-se às suas disposições. A participação reservada ao Congresso, por outro lado, justifica-se, em primeiro lugar, pelo fato de que a ratificação de um tratado importa no comprometimento da soberania nacional, o que não pode, em uma democracia, ser consentido senão mediante a aprovação pelo órgão que exprime a vontade do povo, detentor do poder soberano; em segundo lugar, porque ao Poder Legislativo é reservado o controle dos atos do Executivo, em razão da sistemática de checks and balances, existente em toda organização estatal que adota o princípio da separação orgânica de poderes. Com base em tais considerações, é mister distinguir o ato de ratificação do tratado (realizado pelo Executivo), do ato de autorização da ratificação, também chamado de aprovação do texto (realizado pelo Legislativo).

\footnotetext{
${ }^{297}$ Não há como deixar de atribuir uma parcela de culpa ao legislador constituinte por essa incorreção. Como bem evidencia JOSÉ CRETELLA JÚNIOR o vocábulo "resolver" configura-se um termo genérico, impreciso e, portanto, estranho à terminologia técnica do Direito Público. In Comentários à Constituição de 1988, $2^{\mathrm{a}}$ ed., Rio de Janeiro, Forense, 1992, p. 2532. Em igual direção, ANTÔNIO PAUlo CACHAPUZ DE MEDEIROS considera a expressão como a mais inadequada, pois a decisão do Congresso Nacional só é definitiva quando este rejeita o tratado; caso aprove, a última palavra é do Presidente que poderá, ou não, ratificá-lo. In $O$ Poder de Celebrar Tratados - Competência dos Poderes Constituídos para a Celebração de Tratados à Luz do Direito Internacional, do Direito Comparado e do Direito Constitucional Brasileiro, Porto Alegre, Sérgio Antônio Fabris Editor, 1995, p. p. 117-118; ${ }^{298}$ Op. cit. (Direito Internacional...), p. 168.
} 
O Congresso Nacional não ratifica propriamente nenhum tipo de ato internacional, mas apenas abona ou não o texto convencional, por meio da expedição de um decreto legislativo. Sua aprovação, entretanto, é condição de validade para que o Presidente da República (a quem a Constituição dá competência para celebrar acordos internacionais) realize a ratificação. ${ }^{299}$

É necessário, por derradeiro, fazer o seguinte registro: se, por um lado, o aval do Legislativo é condição obrigatória à ratificação do instrumento nacional (o que permite a inferência de que a rejeição do texto convencional pelo Congresso impede a sua ratificação pelo Executivo), por outro lado, o Presidente da República (titular da competência privativa de manter relações com os Estados estrangeiros) é quem tem a última palavra quanto à decisão de confirmar a vinculação do país aos preceitos de um tratado, podendo deixar de ratificá-lo, mesmo na hipótese em que o Congresso Nacional tenha dado sua autorização para tanto. Conclui-se, dessa forma, que a despeito da imprescindibilidade da confluência de vontades entre o Legislativo e o Executivo é possível afirmar que o ato de ratificação continua sendo um ato discricionário desse último. $^{300}$

${ }^{299}$ A esse respeito, é conveniente que se transcreva a precisa lição de ANTÔNIO PAULO CACHAPUZ DE MEDEIROS, para quem:

"Os Parlamentos não ratificam tratados internacionais. Somente os examinam, autorizando ou não o Poder Executivo a comprometer o Estado.

A ratificação, por conseguinte, é ato privativo do Chefe do Executivo, pelo qual este confirma às outras partes, em caráter definitivo, a disposição do Estado de cumprir um tratado internacional.

Assim, convém fique nítido que a aprovação dada pelo Poder Legislativo não torna um tratado obrigatório, pois o Executivo tem ainda a liberdade de ratificá-lo ou não, conforme julgar mais conveniente.

Essa regra é universal, sendo entendimento unânime que a decisão de ratificar cabe ao mesmo Poder em nome do qual foram assinados os tratados.

Alega-se, basicamente, que, passado algum tempo da assinatura do acordo internacional, podem ter mudado as circunstâncias políticas, e a nova conjuntura não recomendar mais o engajamento do Estado". In op. cit., p. p. 133-134 . O mesmo entendimento é também defendido por: JOSÉ FRANCISCO REZEK, Direito Internacional Público- Curso Elementar, 6a ed. São Paulo, Saraiva, 1996, p. 69; MIRTô FrAGA, op. cit., p.p. 68-69; LuIZ Flávio Gomes, A Questão da Obrigatoriedade dos Tratados e Convenções no Brasil - Particular Enfoque da Convenção Americana sobre Direitos Humanos, in RT, 710 (1994), p.p. 21-31; VALÉRIO DE OLIVEIRA MAZZUOLI, op. cit.(Direito Internacional...), p. p. 168-170; dentre outros.

${ }^{300}$ Nesse sentido, lapidar é a conclusão de HILDEBRANDO ACCIOLY, em parecer proferido como Consultor Jurídico do Itanmaraty, para quem "a rejeição pelo congresso impede a ratificação; a aprovação permite-a, mas não a torna obrigatória". In Boletim da Sociedade Brasileira de Direito Internacional, 8 (1948), p. 166, apud VALÉRIO DE OlIVEIRA MAZZUOLI, op. cit. (Direito Internacional...), p. 173. 


\subsection{O Procedimento Geral para a Incorporação dos Tratados} Internacionais ao Direito Brasileiro

O rito relativo à integração dos tratados internacionais adotado pelo sistema normativo brasileiro inicia-se com o envio à Câmara dos Deputados de mensagem do Presidente da República, acompanhada do texto integral do tratado, bem como, de uma Exposição de Motivos, normalmente elaborada pelo Ministro das Relações Exteriores.

A regra que determina o endereçamento da mensagem à Câmara - e não ao Senado - pode ser apreendida a partir da interpretação teleológica do disposto no caput art. 64 da Constituição da República segundo o qual "A discussão e votação dos projetos de lei de iniciativa do Presidente da República, do Supremo Tribunal Federal e dos Tribunais Superiores terão início na Câmara dos Deputados”.

Na citada Casa Parlamentar, dá-se início à elaboração do decreto legislativo, por meio do qual se aprova o texto do instrumento internacional e concede-se a autorização para a sua ratificação.

Apenas no caso de aprovação do texto convencional pela Câmara dos Deputados é que o projeto de decreto legislativo seguirá para o Senado Federal.

A edição do decreto somente ocorrerá se, em cada uma das Casas do Congresso Nacional, for obtido, em um único turno, o voto favorável da maioria dos parlamentares presentes nas respectivas sessões deliberativas, desde que, dentre os presentes esteja a maioria dos membros da Câmara dos Deputados ou do Senado Federal, conforme for o caso.

Mencionada disciplina tem seu fundamento no art. 47 da Constituição Federal que preceitua: "Salvo disposição constitucional em contrário, as deliberações de cada Casa e de suas Comissões serão tomadas por maioria dos votos, presente a maioria absoluta de seus membros". ${ }^{301}$

É possível, em ambas as casas, a apresentação de emendas aos projetos de decreto legislativo. Tais emendas, porém, não podem, em nenhuma hipótese, serem confundidas com modificações do conteúdo do tratado, o que seria inadmissível, pois

\footnotetext{
${ }^{301}$ Atualmente, como será visto no próximo subitem desta seção, o novel $\S 3^{\circ}$ do art. $5^{\circ}$ da Constituição, introduzido pela Emenda referida, prescreve um regime diferenciado para os instrumentos internacionais de direitos humanos.
} 
implicaria em modificação daquilo que fora objeto de ajuste entre os sujeitos envolvidos em sua celebração. ${ }^{302}$

Acaso ocorra, no Senado, alguma emenda ao projeto de decreto legislativo que extrapole os limites de uma simples correção formal de seu texto, este retornará à Câmara de Deputados para novo reexame, conforme determina o art. 65, parágrafo único da Constituição Federal.

Havendo a aprovação do decreto legislativo nas duas Casas, o Presidente do Senado Federal - que é também o Presidente do Congresso Nacional (art. 57, $\S 5^{\circ}$, da Constituição) - procede à sua promulgação. Após, o decreto é numerado pela Secretaria Geral da Mesa do Senado e levado à publicação no Diário Oficial da União.

Uma vez publicado o decreto legislativo, o Presidente da República estará autorizado (e não obrigado, como já se destacou) a efetuar a ratificação do tratado.

A simples ratificação não faz, todavia, com que a norma internacional gere efeitos na ordem interna. A prática brasileira tem exigido, para que isso ocorra, que o Presidente da República expeça um decreto de execução, cuja finalidade é a de promulgar o conteúdo do tratado e determinar sua publicação no Diário Oficial da União. Explica VALÉRIO DE OLIVEIRA MAZZUOLI que "a promulgação e a publicação, no sistema brasileiro, compõem a fase integratória da eficácia da lei, vez que atestam a sua adoção pelo Poder Legislativo, certificam a existência de seu texto e, afirmam, finalmente, seu valor imperativo e executório". 303

Cumpre ressaltar, não obstante, que, para parte da doutrina, o decreto executivo não constitui um reclamo constitucional. Conforme observa JosÉ FRANCISCO REZEK, corresponde ele a um produto da praxe adotada no país, desde a Independência e os primeiros exercícios convencionais do Império. Sua essência é a de um mero ato de publicidade da existência de um tratado e sua forma - a de um decreto - justifica-se unicamente porque os atos do Chefe de Estado costumam ser assim externados. ${ }^{304}$

Em direção oposta, há correntes que sustentam que a promulgação dos tratados ratificados seria uma decorrência do disposto no art. 84, IV, da Constituição Federal, que estabelece competir ao Presidente da República "sancionar, promulgar e fazer

\footnotetext{
${ }^{302}$ No caso específico das convenções internacionais do trabalho, a proibição de alteração do texto é ainda mais evidente, porquanto não se admite nem mesmo a ratificação com reservas.

${ }^{303}$ Op. cit. (Direito Internacional...), p. 185.

${ }^{304}$ Op. cit. (Direito dos Tratados...), p. p. 385-386.
} 
publicar as leis, bem como expedir decretos e regulamentos para sua fiel execução". A interpretação ampliativa do vocábulo "lei", contido no preceptivo transcrito, permitiria a aplicação dessa regra também aos instrumentos internacionais ratificados. ${ }^{305}$

\subsection{Especificidades Relacionadas à Incorporação dos Tratados}

\section{Internacionais de Direitos Humanos}

\subsubsection{As Teses sobre a Incorporação Automática}

Respeitável parte da doutrina nacional, escorada no princípio da aplicação imediata das normas definidoras de direitos e garantias fundamentais, insculpido no art. $5^{\circ}$, $\S 1^{\circ}$, da Constituição Federal $^{306}$, sustenta que a incorporação dos instrumentos internacionais sobre direitos humanos ao Direito pátrio diferencia-se daquela relativa aos demais tratados, por dispensar qualquer procedimento legislativo formal para tanto.

Nesse sentido, emblemático é o magistério de ANTÔNIO Augusto CANÇADO TRINDADE, segundo o qual:

(...) a especificidade e o caráter especial dos tratados de proteção internacional de direitos humanos encontram-se, com efeito, reconhecidos e sancionados pela Constituição Brasileira de 1988: se, para os tratados internacionais em geral, se tem exigido a intermediação pelo Poder Legislativo de ato com força de lei, de modo a outorgar às suas disposições vigência ou obrigatoriedade no plano do ordenamento jurídico interno, distintamente no caso dos tratados de proteção internacional dos direitos humanos em que o Brasil é parte os direitos fundamentais neles garantidos passam, consoante o art. $5^{\circ}, \S 1^{\circ} \mathrm{e}$ $2^{\circ}$, da Constituição Brasileira de 1988, a integrar o elenco dos direitos constitucional mente consagrados e imediatamente exigíveis no plano do ordenamento jurídico interno. ${ }^{307}$

\footnotetext{
${ }^{305}$ Nesse sentido, confira-se MiRTô FraGA, op. cit., p. p. 63-64.

${ }^{306}$ Sobre tal princípio, confira-se o item 1.5.2., c, do Capítulo anterior.

307 Direito Internacional e Direito Interno - Sua Interpretação na Proteção de Direitos Humanos, in Instrumentos Internacionais de Proteção dos Direitos Humanos, $2^{\mathrm{a}}$ ed., San Jose - Costa Rica/Brasília, IIDH, 1996, p. p. 20-21; Na mesma direção, confira-se também CELSO RIBEIRO BASTOS e IVES GANDRA MARTINS, Comentários à Constituição de 1988, vol. II, São Paulo, Saraiva, 1989, p. p. 395-396.
} 
Muito embora a referida tese mostre-se compatível ao intento de se conferir uma maior efetividade à proteção dos direitos humanos, é mister destacar a inexistência, na Constituição da República, de prescrição expressa que autorize a recepção automática de instrumentos internacionais. Pelo contrário, uma análise um pouco mais cuidadosa do art. $5^{\circ}, \S 2^{\circ}$, da Constituição permite verificar que a opção do legislador, mesmo em se tratando de instrumentos internacionais relativos a direitos humanos, foi a da necessidade de um ato formal de adesão. De fato, citado preceito faz remissão expressa a "tratados internacionais em que a República Federativa do Brasil seja parte" (grifos ausentes no texto original), o que significa, em outros termos, o condicionamento da recepção dos tratados ao disposto nos arts. 49, I, e 84, VIII, da Constituição.

Além disso, cumpre ressaltar que sempre foi da tradição constitucional brasileira a regra que estabelece o concurso de atos do Executivo e Legislativo para consecução válida da integração dos tratados internacionais ao Direito pátrio. A justificativa para a existência da interação entre ambos os Poderes na dinâmica da recepção dos tratados já foi exposta no item 2.1. deste capítulo. Convém, porém, retomar aqui a idéia de que a participação do Legislativo dá-se por uma dupla razão: exercer o controle dos atos praticados pelo Presidente da República, evitando-se, assim, abusos por parte do Chefe do Executivo na celebração de tratados; expressar a vontade popular, indispensável, pelo fato de que a ratificação de um tratado importa no comprometimento da soberania nacional.

Tendo em vista essas noções, perfeita mostra-se a crítica de INGO WOLFGANG SARLET à tese da que dispensa a manifestação legislativa para integração dos tratados, feita nos seguintes moldes:

(...) ora, justamente quando o Constituinte, objetivando evidentemente coibir excessos por parte do Executivo no que tange à celebração de tratados internacionais, previu a necessidade de procedimento legislativo prévio para a sua incorporação definitiva ao direito interno, regra esta embasada, ademais, em abalizada doutrina sobre a matéria, torna-se no mínimo de difícil sustentação o ponto de vista segundo o qual, no concernente aos tratados internacionais sobre direitos humanos (fundamentais), bastaria meramente o aval do Executivo. Considerar-se a regra contida no art. $5^{\circ}, \S 2^{\circ}$, da $\mathrm{CF}$, em que pese a ausência de disposição expressa sobre o tema, como tendo caráter excepcional, quando justamente 
restringe a legitimação democrática na recepção de normas internacionais, não nos parece ser a melhor solução, ao menos sob a ótica do direito constitucional positivo pátrio (...). ${ }^{308}$

Adotando uma posição intermediária, uma segunda corrente doutrinária ${ }^{309}$, também arrimada no mesmo dispositivo constitucional, defende que tal distinção não se situa exatamente no procedimento a ser observado para a ratificação - que continua seguindo como etapa necessária à integração das normas internacionais e sendo regulada pelas mesmas regras gerais supra aludidas - mas na fase final desse processo, relativa à imprescindibilidade de expedição, pelo Presidente da República, do decreto de execução.

A esse respeito, VALÉRIO DE OLIVEIRA MAZZUOLI, após discorrer sobre as imprecisões cometidas pelos autores que sustentam a primeira posição e defender a existência de um único iter procedimental a reger a recepção dos tratados na ordem jurídica nacional, assevera que a diferença básica relativa aos instrumentos internacionais de direitos humanos está na dispensa do ato de promulgação. Para o distinto jurista,

(...) os tratados internacionais de direitos humanos por nós ratificados, têm aplicação imediata no Brasil, independentemente da edição de diploma normativo com força de lei (decreto de execução Presidencial) que os materialize, para que só assim irradiem seus efeitos tanto no plano interno como no plano internacional. É desnecessária, portanto, a posterior edição, pelo Executivo, de decreto de execução ou decreto executivo. Basta a ratificação do tratado, para que sua incorporação ao direito interno se faça de imediato, é dizer, automaticamente. ${ }^{310}$

Como conseqüência da distinção de regimes, concluem FLÁVIA PIOVESAN ${ }^{311}$ e VALÉRIO DE OLIVEIRA MAZZUOLII ${ }^{312}$, partidários dessa linha de pensamento, que o Brasil teria abraçado o sistema monista de integração do Direito Internacional ao Direito interno no que se refere aos tratados de direitos humanos, ao passo que, em relação às demais normas convencionais sua opção teria sido a teoria dualista, porquanto há a exigência do decreto executivo.

\footnotetext{
${ }^{308}$ Op. cit., p. p. 143-144.

309 Confira-se a respeito VALÉRIO DE OliveIRA MAZZUOLI, Direitos Humanos e Relações Internacionais, Campinas, Agá Júris, 2000, p. p. 109-124; FláVIA PIOVESAN, op. cit., p. p. 80-91.

${ }^{310}$ Op. cit. (Direitos Humanos...), p. 122.

${ }^{311}$ Op. cit. (Direitos Humanos e o Direito Constitucional Internacional...), p. 86.

${ }^{312}$ Op. cit. (Direito Internacional...), p. 156.
} 
A posição supra é igualmente passível de crítica. Novamente, pode-se argumentar que a Constituição da República não contém regra expressa, dispondo sobre um regime diferenciado de recepção de tratados de direitos humanos que dispense o decreto de execução. Embora o art. $5^{\circ}, \S 1^{\circ}$, preveja a aplicação imediata das normas definidoras dos direitos e garantias fundamentais, poder-se-ia argumentar que o alcance desse princípio diz mais respeito à questão da eficácia de norma que já faz parte do sistema jurídico (a esse respeito, confira-se o item do 1.5.2, $c$, do capítulo III), do que propriamente ao fenômeno da integração do Direito Internacional ao Direito interno.

Contra a tese, poder-se-ia apor, ainda, que com a ausência do decreto não se daria a devida publicidade aos tratados incorporados, o que seria algo inaceitável. Isso porque, a publicidade das leis em sentido amplo (o que engloba toda produção legislativa doméstica e internacional) é um imperativo do Estado Democrático de Direito e se encontra insculpida no art. 84, IV, da Constituição Federal.

Acrescente-se, ainda, a opinião jurisprudencial, solidificada na decisão do Supremo Tribunal Federal, segundo a qual:

O decreto presidencial que sucede à aprovação congressual do ato internacional e à troca dos respectivos instrumentos de ratificação, revela-se - enquanto momento culminante do processo de incorporação desse ato internacional ao sistema jurídico doméstico - manifestação essencial e insuprimível, especialmente se considerados os três efeitos básicos que lhe são pertinentes: a) a promulgação do tratado internacional; b) a publicação oficial de seu texto; e c) a executoriedade do ato internacional, que passa, então, e somente então, a vincular e a obrigar no plano do direito positivo interno. ${ }^{313}$

Todavia, é inegável que em relação à posição inicialmente vista, essa última mostra-se mais adequada ao direito positivo pátrio e, por esse prisma, mais sólida e defensável. A favor dela, é possível aduzir que os tratados de direitos humanos, por conterem valores mais caros à sociedade, não podem ter, uma vez ratificados, sua vigência condicionada a um ato formal do Presidente da República, que pode simplesmente nunca ocorrer, por força de conjecturas políticas. Adotando-se a lição de FLÁVIA PIOVESAN, segundo a qual é necessário que se leve em conta a força expansiva do valor supremo da dignidade humana e dos direitos fundamentais, como parâmetros axiológicos a orientar a

${ }^{313}$ ADIn 1.408-DF, rel. Min. CELSO DE MELLO, julgado em 4.9.1997, publicado no DJU em 18.5.2001. 
compreensão do fenômeno constitucional, ${ }^{314}$ revela-se plenamente aceitável uma interpretação sistemática e teleológica do disposto nos art. $5^{\circ}, \S 1^{\circ}$ e $2^{\circ}$, da Constituição, que permita concluir que a recepção dos tratados de direitos humanos adviria somente da ratificação. De fato, por meio de uma interpretação mais favorável aos direitos humanos permite-se dar um maior alcance ao próprio princípio da aplicabilidade imediata, de modo a albergar também a tese da dispensa de qualquer ato formal subseqüente à ratificação para a recepção dos tratados.

\subsubsection{A Problemática Suscitada pela Emenda Constitucional n. 45/04}

No que tange à questão da incorporação dos tratados de direitos humanos ao ordenamento pátrio, constata-se que, após a promulgação da Constituição da República de 1988, ampliou-se, ainda mais, a cizânia doutrinária sobre o assunto.

As divergências existentes dão-se não apenas em torno da matéria relativa ao procedimento de integração dos tratados de direitos humanos, como se acabou de assinalar no subitem anterior, mas especialmente, acerca da posição que tais instrumentos ao adentrar a ordem jurídica nacional passam a ocupar na hierarquia das normas, como será visto oportunamente.

Com o intuito de resolver principalmente essa última questão, a Emenda Constitucional n. 45/04 introduziu ao art. $5^{\circ}$ da Constituição Federal um $\S 3^{\circ}$, com a seguinte redação: "Os tratados e convenções internacionais sobre direitos humanos que forem aprovados, em cada Casa do Congresso Nacional, em dois turnos, por três quintos dos votos dos respectivos membros, serão equivalentes às emendas constitucionais".

Longe de resolver o problema mencionado, o preceptivo in casu suscitou novas controvérsias, que não se cingem apenas à questão da hierarquia, abarcando também a matéria da incorporação, em virtude da menção expressa a uma aprovação dos instrumentos internacionais de direitos humanos por um quórum qualificado e em dois turnos de votação em ambas as Casas Legislativas.

\footnotetext{
${ }^{314}$ Op. cit. (Direitos Humanos e o Direito Constitucional Internacional...), p. 52.
} 
Para parcela da doutrina, tal comando traduziria uma nova disciplina da aprovação legislativa dos instrumentos internacionais de direitos humanos, considerada como etapa necessária à ratificação levada a efeito pelo Poder Executivo. Esta parece ser, por exemplo, a posição defendida por INGO WOLFGANG SARLET, para quem haveria espaço para uma "interpretação teleológica e sistemática em prol da compulsoriedade do procedimento reforçado das emendas constitucionais". De acordo com o insigne jurista, após a Emenda n. 45/04, a aprovação dos tratados de direitos humanos pelo Congresso Nacional, antes feita por decreto legislativo, deverá agora obedecer ao processo mais rigoroso das reformas constitucionais, visando a assegurar aos direitos neles consagrados um status jurídico diferenciado, compatível com a sua fundamentalidade. ${ }^{315}$

Objeta-se, contudo, que tal entendimento traduziria a adoção de um rito mais dificultoso para a recepção de documentos internacionais em matéria de direitos humanos, o que colidiria com o princípio fundamental insculpido no art. $4^{\circ}$, II, segundo o qual o Brasil seria regido pela prevalência dos direitos humanos no plano de suas relações internacionais. ${ }^{316}$

Para INGo WolfGang SARLET, entretanto, a aprovação do texto convencional pelo Congresso em dois turnos e com o quórum qualificado de três quintos seria um ponto positivo, porquanto enrobusteceria "a legitimação democrática desses direitos, o que, por sua vez, concorre para a sua maior força normativa - em suma, para uma pretensão de eficácia e efetividade reforçadas - indispensável também para reforçar a posição do nosso País em face da comunidade internacional". 317

Solução mais engenhosa à objeção referida é apresentada por VALÉRIO DE OliVEIRA MAZZUOLI, para quem a sistemática de integração dos tratados estabelecida pelos arts. 49, I, e 84, VIII, da Constituição Federal não teria sofrido nenhuma alteração com a Emenda n. 45/04, seguindo aplicável a todos os instrumentos internacionais, inclusive aqueles que consagram direitos humanos. Para o referido autor,

(...) o $\S 3^{\circ}$ do art. $5^{\circ}$ não obriga o Poder Legislativo a aprovar eventual tratado de direitos humanos pelo quorum qualificado que estabelece. O que o parágrafo faz é tão-somente

\footnotetext{
315 Op. cit., p. p. 153-154.

316 Tal argumento pode ser invocado, inclusive, para se sustentar a própria inconstitucionalidade do $\S 3^{\circ}$, introduzido pela Emenda Constitucional n. 45/04, que teria representado um verdadeiro retrocesso em matéria de recepção dos tratados de direitos humanos.

${ }^{317}$ Op. cit., p. 153.
} 
autorizar o Congresso Nacional a dar, quando lhe convier, a seu alvedrio e a seu talante, a “equivalência de emenda" aos tratados de direitos humanos ratificados pelo Brasil. Isto significa que tais instrumentos internacionais poderão continuar sendo aprovados por maioria simples no Congresso Nacional (segundo a regra do art. 49, I, da Constituição), deixando-se para um momento futuro (depois da ratificação) a decisão do povo brasileiro em atribuir a equivalência de emenda a tais tratados internacionais. ${ }^{318}$

A proposta em questão leva em conta uma interpretação do $\S 3^{\circ}$ do art. $5^{\circ}$, que se harmoniza com os demais preceitos relacionados ao processo constitucional estabelecido para a celebração de tratados. De acordo com ela, o novel dispositivo visou apenas à criação de um mecanismo que permita a equiparação de instrumentos internacionais de direitos humanos já incorporados ao mesmo status ocupado pelas emendas constitucionais. Em outros termos, não pretendeu ele, em nenhum momento, excepcionar a regra estabelecida no art. 49, I, da Constituição Federal. Fosse esse o caso, estaria, no mínimo, topologicamente mal colocado, já que deveria vir na sequiência deste e não incluído ao final do rol de garantias e direitos fundamentais. Além disso, caso prevalecesse o entendimento de que a redação do $\S 3^{\circ}$ do art. $5^{\circ}$ implicasse a substituição da regra contida no art. 49, I, estar-se-ia diante da recepção de tratados sem o ato de ratificação, uma vez que, pela leitura do preceptivo introduzido pela reforma de 2004, a simples aprovação do tratado pelo Congresso já o colocaria em posição equivalente à emenda constitucional (o que pressuporia, obviamente, sua integração à ordem jurídica nacional). Tal não se afigura, porém, como aceitável. ${ }^{319}$ Como já destacado no item 2.1 deste capítulo, cabe ao Presidente da República a condução da política externa do país, recaindo sobre ele todas as etapas do processo de conclusão dos tratados, inclusive aquela relativa ao consentimento final do Estado em obrigar-se às suas disposições. ${ }^{320}$

Finalmente, cumpre destacar que a posição que sustenta a existência de um procedimento dúplice apresenta, ainda, outra vantagem: permitir que os tratados de direitos humanos já integrados ao sistema jurídico nacional antes da vigência da Emenda n. 45/04

\footnotetext{
${ }^{318}$ Curso de Direito Internacional Público, São Paulo, RT, 2006, p. 499.

${ }^{319}$ Esse obstáculo poderia ser superado, porém, com base em uma análise sistemática dos artigos $5^{\circ}$, $\S 3^{\circ}$, e 84, VIII, da Constituição, pela qual não se desconsideraria a ratificação como etapa necessária à recepção dos tratados internacionais de direitos humanos. Por meio dela, ainda que o procedimento estabelecido no citado $\S 3^{\circ}$ seja entendido como substitutivo ao disposto no art. 49, I, do Texto Constitucional, o efeito nele previsto (de equiparar os instrumentos internacionais de direitos humanos às emendas constitucionais) somente ocorrerá após a ratificação e entrada em vigência internacional do tratado.

${ }^{320}$ A esse respeito confira-se VALÉRIO DE OLIVEIRA MAZZUOLI, op. cit. (Curso...), p. p. 499-501.
} 
possam, a qualquer tempo, serem submetidos ao procedimento estabelecido no $\S 3^{\circ}$ do art. $5^{\circ}$ e tornarem-se, do ponto de vista formal, também equivalentes às emendas constitucionais.

A tese, todavia, não é isenta de críticas. Seu próprio elaborador, VALÉRIO DE OLIVEIRA MAZZUOLI, aponta que a liberdade conferida ao legislador não é salutar nem ao princípio da segurança jurídica, nem aos princípios que devem reger as relações internacionais do Brasil, uma vez que permitiria o tratamento diferenciado de instrumentos com igual conteúdo principiológico. ${ }^{321} \mathrm{O}$ reconhecimento dessa imperfeição fortalece, novamente, a exegese relativa à compulsoriedade da aplicação do rito especial das emendas em substituição à regra estatuída no art. 49, I, no que toca à incorporação de tratados de direitos humanos. ${ }^{322}$

Ante o exposto, verifica-se o quão problemática tornaram-se as alterações introduzidas pela Emenda Constitucional n. 45/04 em matéria de integração de tratados internacionais de direitos humanos ao ordenamento jurídico pátrio. Diante das inúmeras possibilidades interpretativas, da falta de maior amadurecimento doutrinário sobre o tema e, ainda, da inexistência de jurisprudência relativa à matéria, resta apenas uma certeza: qualquer solução que se adote mostra-se, em maior ou menor grau, sustentável e, portanto, válida, o que não significa, entretanto, que esteja alheia a críticas.

\subsection{A Incorporação das Convenções Internacionais do Trabalho ao}

\section{Direito Brasileiro}

A Constituição da OIT estabelece um procedimento formal, pelo qual os Estados-Membros afirmam perante a Organização seu compromisso em se submeterem às normas estabelecidas nas convenções internacionais do trabalho aprovadas pela Conferência.

Tal procedimento possui uma disciplina ditada pelo Direito Internacional ou, mais exatamente, pela sistemática normativa da própria Organização Internacional do Trabalho - e uma disciplina ditada pelo Direito interno de cada país.

\footnotetext{
${ }^{321}$ Op. cit.(Curso...), p. 501.

${ }^{322}$ Nesse sentido, confira-se INGO WOLFGANG SARLET, op. cit., p. 156.
} 
As referidas disciplinas, por sua vez, já foram objeto de detida análise em itens anteriores desta dissertação ${ }^{323}$, não cabendo, aqui reproduzir tudo o que já foi dito até agora, mas apenas promover uma breve síntese das principais regras aplicáveis às convenções.

No plano internacional, cumpre destacar que após a aprovação de uma convenção pela Conferência Internacional do Trabalho, esta se abre à ratificação pelos países membros da Organização, consoante o disposto no art. 19, $\S 5^{\circ}, a$, da Constituição da OIT. A ratificação das convenções internacionais do trabalho, diferentemente, dos demais tratados internacionais não pressupõe assinaturas prévias por parte dos plenipotenciários dos Estados, tampouco o intercâmbio de documentos, perfazendo-se apenas com uma comunicação formal sobre sua realização ao Diretor-Geral do Bureau Internacional do Trabalho (art. 19, $\S 5^{\circ}, d$, da Constituição da OIT).

A estrutura e objetivos da Organização, bem como, o específico processo existente para a adoção das convenções, não permitem que estas sejam ratificadas sob reservas. Todavia, algumas dessas convenções facultam, por meio de fórmulas de flexibilidade, que o Estado, ao ratificá-las, aceite ou não partes específicas do conteúdo desses instrumentos ou fixe o nível e a forma em que a aplicação da norma é aceita. Além disso, admite-se a chamada ratificação condicional das convenções, embora esta prática tenha caído em desuso.

No que se refere ao regramento estabelecido pelo Direito brasileiro, cumpre ressaltar que, como tratados internacionais que são, as convenções internacionais do trabalho encontram-se submetidas ao mesmo procedimento relativo à recepção dos tratados em geral, permitindo-se, em se tratando de convenções internacionais do trabalho sobre direitos humanos, que sejam invocadas todas as especificidades já referidas sobre a integração de tratados de direitos humanos.

Assim é que as convenções internacionais do trabalho deverão ser endereçadas pelo Presidente da República ao Congresso Nacional para elaboração de decreto legislativo, por meio do qual se aprova o texto do instrumento internacional e concede-se a autorização para a sua ratificação.

Publicado o decreto legislativo, o Presidente da República estará autorizado a ratificar a convenção internacional do trabalho, a qual somente produzirá efeitos internos

${ }^{323}$ A respeito, conferir item 5.2. do Capítulo II e 2.1., 2.2, 2.3 deste Capítulo. 
com a expedição do decreto de execução, promulgando-a e conferindo-lhe publicidade, caso, por óbvio também já esteja em vigência internacionalmente.

$\mathrm{Na}$ hipótese de convenções internacionais do trabalho sobre direitos humanos ratificadas, pode-se sustentar, com base no princípio da aplicação imediata dos direitos fundamentais (art. $5^{\circ}, \S 1^{\circ}$, da Constituição Federal), ser dispensável o decreto de execução para a irradiação de seus efeitos no âmbito nacional.

Ademais, é defensável que, a partir da Emenda Constitucional n. 45/04, o procedimento para a integração desses instrumentos sofreu, no Direito pátrio, significativa alteração. Nesse diapasão, a doutrina tem-se posicionado acerca de dois entendimentos distintos.

Segundo o primeiro deles, é razoável supor que, desde a introdução do $\S 3^{\circ}$ ao art. $5^{\circ}$ da Constituição Federal, todas as convenções internacionais do trabalho cujo conteúdo seja de direitos humanos deverão ser obrigatoriamente aprovadas pelo Congresso Nacional, por um sistema análogo ao de votação das emendas constitucionais, para que só então possam ser ratificadas pelo Presidente da República.

De acordo com o segundo entendimento, a partir da alteração introduzida pelo poder constituinte reformador, passou-se a adotar um procedimento dúplice, pelo qual subsistiriam as mesmas etapas contempladas até a ratificação, mas, posteriormente a ela, seria permitida a submissão, a qualquer momento, das convenções a uma nova aprovação legislativa, agora sob a forma análoga ao da elaboração de emendas constitucionais, com o único propósito de conferir-lhes o mesmo status hierárquico que estes instrumentos.

\subsection{O Jus Cogens e a Declaração da Organização Internacional do} Trabalho sobre os Princípios e Direitos Fundamentais no Trabalho: Desnecessidade de Ratificação das Convenções?

\section{Assevera Guido Fernando Silva SoARES que:}

(...) no século XX, duas tendências emergiram no Direito Internacional Público, relativas a uma reformulação do entendimento tradicional sobre suas fontes e o papel de uma gradação de uma força vinculante, para os Estados, das normas jurídicas por eles produzidos ou destinadas a eles. De um lado, o reconhecimento de existir um núcleo duro e relativamente 
inflexível de normas jurídicas, que, como as cláusulas pétreas das Constituições dos Estados, condicionam a legitimidade e a validade de todas as outras normas por eles elaboradas. Trata-se da afirmação de haver no Direito Internacional normas que constituiriam um jus cogens, que se sobrepõe à vontade dos Estados, e não podem ser modificadas por dispositivos oriundos, seja nos tratados e convenções internacionais, seja nas normas consuetudinárias internacionais, seja ainda, por estarem definidas como princípios gerais do direito (...). De outro lado, o reconhecimento de existirem normas muito flexíveis, que constituiriam conjunto de regras jurídicas de conduta dos Estados, cuja inadimplência seria governada por um sistema de sanções distintas das previstas nas normas tradicionais, possivelmente assimiláveis às obrigações morais versadas nos sistemas obrigacionais internos dos Estados; trata-se da discussão sobre a existência do que se tem denominado de soft law, por oposição às normas tradicionais, então qualificadas de hard laws. $^{324}$

Prossegue o citado autor, esclarecendo que a emergência dessas teorias, com características aparentemente antagônicas, deveu-se ao fato de, em meados do século $\mathrm{XX}^{325}$, o Direito Internacional ter ganhado novo conteúdo, não mais se restringindo a um conjunto de normas de meras proibições a Estados todo-poderosos, mas também um conjunto de normas comissivas a eles impostas. Abandona-se, a partir de tal fase, a idéia de que o conteúdo do Direito Internacional equivaleria a um conjunto de normas de autocontenção dos Estados, ganhando relevo outros valores que informam a força geradora de direitos no plano internacional e relativizam a própria noção de soberania. ${ }^{326}$

Nesse sentido, o jus cogens representaria o afastamento do Direito Internacional das teorias voluntaristas exacerbadas dos séculos passados, que viam na manifestação de vontade dos Estados, expressa nos tratados internacionais, ou implícita no costume internacional a única fonte das normas jurídicas. Segundo GuIDO FERNANDO SILVA SOARES, a teoria do jus cogens nada mais seria do que o resgate de importantes teses do jusnaturalismo do século XVI, formuladas no momento do próprio nascimento do Direito Internacional, com uma roupagem mais sofisticada e dentro de um sistema jurídico

\footnotetext{
${ }^{324}$ Op. cit., p. 127.

325 Ao tratar sobre a emergência do jus cogens expõe ANTONIO CASSESE: "The upgrading of certain fundamental rules produced by traditional sources of law occured in the late 1960's as a result of the endeavours of socialist and developing countries. These countries claimed that certain norms governing relations between States should be given a higher rank than ordinary rules deriving from treaties and custom". Ou seja, "A elevação de certas regras fundamentais produzidas por fontes de direito tradicionais ocorreu no final da década de 1960, como resultado dos esforços dos países socialistas e em desenvolvimentos. Esses países alegam que a determinadas normas que regulam as relações entre Estados deve ser dada uma hierarquia superior às regas ordinárias derivadas de tratados e do costume". (tradução livre). In International Law, $2^{\mathrm{a}}$ ed., Oxford, Oxford University Press, 2005, p. 199.

${ }^{326}$ GUIDO FERNANDO SILVA SOARES, op. cit., 128.
} 
coerente, composto de um conjunto amplo de normas e princípios, bem como, de uma metodologia rigorosa de exame das fontes do direito. ${ }^{327}$

Finalmente, conclui o mencionado jurista:

(...) ousaríamos dizer que, num paralelismo do que ocorrera nos ordenamentos jurídicos nacionais, a consciência de normas superiores à vontade do legislador ordinário, que tinha sido a base do contratualismo do século XVII e fundamentaria os movimentos constitucionalistas do século XVIII, viria a suceder no século XX, com a emergência das discussões sobre o jus cogens! $!^{328}$

O reconhecimento expresso do jus cogens na órbita internacional deu-se com a Convenção de Viena sobre o Direito dos Tratados de 1969, em dois de seus artigos: o art. 53 (insculpido em seção relacionada à nulidade de tratados) e o art. 64 (em seção relacionada à extinção e à suspensão da execução de tratados), ambos incluídos na Parte V da Convenção, intitulada: "Nulidade, Extinção e Suspensão da Aplicação dos Tratados". Os termos dos mencionados artigos merecem ser transcritos:

Art. 53

Tratado em conflito como uma Norma Imperativa de Direito Internacional Geral (Jus Cogens).

É nulo o tratado que, no momento de sua conclusão, conflita com uma norma imperativa de direito internacional geral. Para os fins da presente Convenção, uma norma imperativa de direito internacional geral é uma norma aceita e reconhecida pela comunidade internacional dos Estados no seu conjunto, como norma da qual nenhuma derrogação é permitida e que só pode ser modificada por uma nova norma de direito internacional geral da mesma natureza.

Art. 64.

\footnotetext{
${ }^{327}$ Op. cit., p. 128.

${ }^{328}$ GUIDO FERNANDO SILVA SOARES, op. cit., 128. Advirta-se, contudo, que para o referido autor, "claro está que a ainda não se verificou a erosão do conceito de base da legitimidade das normas internacionais, como o constitucionalismo realizou nos sistemas jurídicos nacionais, ao haver deslocado a fonte das normas jurídicas, da pessoa do dirigente da sociedade, transferindo-a para a soberania do povo. Por mais democrático que se pretenda, na atualidade, o Direito Internacional (os indícios são instigantes, a exemplo: a participação da sociedade, pela via dos controles parlamentares, dos principais atos do Executivo, geradores do Direito Internacional, a publicidade dos tratados e convenções internacionais, como obrigações dos Estados na atualidade, a abertura das negociações internacionais à participação direta de representantes da dita "sociedade civil"), ainda continua ele a ser, de maneira preponderante e avassaladora, uma elaboração dos Estados, com responsabilidade centradas nos respectivos Poderes Executivos. In op. cit., p. 218.
} 
Superveniência de uma Nova Norma Imperativa de Direito Internacional Geral (Jus Cogens).

Se sobrevier uma norma imperativa de direito internacional geral, qualquer tratado existente em conflito com essa norma torna-se nulo e extingue-se

Ao tratar sobre o tema, OSCAR ERMIDA URIARTE esclarece que:

(...) o jus cogens ou ordem pública internacional, da qual nenhum Estado, nenhuma pessoa pode fugir, é basicamente a boa-fé nas relações internacionais, o pacta sunt servanda, cumprimento da palavra empenhada, que é uma variante da anterior, e os direitos humanos. ${ }^{329}$ As fontes dessa ordem pública são tratados, pactos e declarações, os princípios gerais do Direito e os costumes internacionais. ${ }^{330}$

Afirma, ainda, o aludido jurista uruguaio, que a importância do tema avulta em relação aos instrumentos internacionais que não requerem ratificação para serem dotados de aplicação obrigatória (v.g. a Declaração Universal dos Direitos do Homem de 1948), ponderando que estes correspondem à regra no Direito Internacional. Adverte, contudo, que no caso das convenções da Organização Internacional do Trabalho, como há previsão de que elas devem ser ratificadas, o tema não se afigura como de grande relevância. ${ }^{331}$

Sem embargo, das valiosas lições de URIARTE, é possível discordar de sua última advertência, sendo importante tecer algumas considerações a esse respeito também em relação às convenções internacionais do trabalho.

Com efeito, a Organização Internacional do Trabalho, acompanhando a evolução do Direito Internacional, parece ter sido fortemente influenciada pela teoria do jus cogens internacional, ao adotar, por meio de sua Conferência, em 1998, a "Declaração

\footnotetext{
329 Não obstante Oscar Ermida Uriarte refira-se genericamente a direitos humanos, informa GEORGE RODRIGO BANDEIRA GALINDO, que "nem todos os direitos humanos podem ser considerados como tendo a natureza jus cogens", mas somente aqueles que forem assim reconhecidos pelo Direito Internacional. In $A$ Reforma do Judiciário como Retrocesso para a Proteção Internacional dos Direitos Humanos: um Estudo sobre o Novo $\$ 3^{\circ}$ do Artigo $5^{\circ}$ da Constituição Federal, in Cena Internacional, 1 (2005), p. p. 89.

${ }^{330}$ OSCAR ERMIDA URIARTE, A Aplicação Judicial das Normas Constitucionais e Internacionais sobre Direitos Humanos Trabalhistas, in Fórum Internacional sobre Direitos Humanos e Direitos Sociais, organização e realização Tribunal Superior do Trabalho, São Paulo, LTr, 2004, p. 287.

${ }^{331}$ Nesse sentido, diz OSCAR ERMIDA URIARTE: "Contudo, há de fazer-se uma advertência, qual seja, a de que também todos os juristas nacionais têm um preconceito: todos atuamos como se a regra fosse a necessidade de ratificação. E no direito internacional é o inverso: a regra é a de que o instrumento internacional tem valor e eficácia desde o momento de sua assinatura e que os instrumentos internacionais só necessitam de ratificação quando o mesmo instrumento exige ratificação para a sua vigência. Nós atuamos ao revés do que é. In op. cit., p. 287.
} 
sobre Princípios e Direitos Fundamentais no Trabalho", a qual estabelece, após algumas considerações, que:

“A Conferência Internacional do Trabalho,

1. Lembra:

a) que no momento de incorporar-se livremente à OIT, todos os Membros aceitaram os princípios e direitos enunciados em sua Constituição e na Declaração de Filadélfia, e se comprometeram a esforçar-se por alcançar os objetivos gerais da Organização na medida de suas possibilidades e atendendo a suas condições específicas;

b) que esses princípios e direitos têm sido expressados e desenvolvidos sob a forma de direitos e obrigações específicos em convenções que foram reconhecidos como fundamentais dentro e fora da Organização.

2. Declara que todos os Membros, ainda que não tenham ratificado as convenções aludidas, têm um compromisso derivado do fato de pertencer à Organização de respeitar, promover e tornar realidade, de boa-fé e de conformidade com a Constituição, os princípios relativos aos direitos fundamentais que são objeto dessas convenções, isto é:
a) a liberdade sindical e o reconhecimento efetivo do direito de negociação coletiva;
b) a eliminação de todas as formas de trabalho forçado ou obrigatório;
c) a abolição efetiva do trabalho infantil; e
d) a eliminação da discriminação em matéria de emprego e ocupação.
(Grifos ausentes no original).

Com base no elenco dos princípios transcritos, a própria Organização Internacional do Trabalho sustenta que seriam oito as convenções a que se refere a regra prevista no art. $2^{\circ}$ da Declaração de 1998: as Convenções $n^{\circ} 87$ e 98, sobre liberdade sindical e reconhecimento efetivo do direito de negociação coletiva; as Convenções $n^{\circ} 29$ e 105, sobre a eliminação de todas as formas de trabalho forçado ou compulsório; as Convenções $\mathrm{n}^{\circ} 100$ e 111, sobre a eliminação da discriminação em matéria de emprego e ocupação; e, finalmente, as Convenções $n^{\circ} 138$ e 182, sobre a abolição efetiva do trabalho infantil.

É indubitável que a manifestação expressada pela Organização Internacional do Trabalho no sentido de que seus países membros devam respeitar, promover e tornar realidade, independentemente de ratificação, os princípios e direitos fundamentais previstos em suas convenções - ainda que seja somente em relação às oito convenções destacadas - por si só, pode ser interpretada como uma primeira etapa para o 
reconhecimento no Direito Internacional sobre a existência de convenções internacionais do trabalho consagradoras de direitos humanos com natureza de jus cogens.

Com efeito, a partir da previsão de que os países, pelo simples fato de pertencerem à Organização Internacional do Trabalho, estariam obrigados a respeitar, promover e tornar realidade os princípios e direitos previstos em suas convenções (pelo menos aquelas ditas fundamentais), seria possível sustentar, em termos singelos, que mencionados instrumentos normativos passariam a ser, de forma plena e imediata, exigíveis não apenas na órbita internacional, mas na ordem jurídica de cada EstadoMembro dessa Organização, gerando-lhes deveres, bem como, direitos subjetivos aos seus respectivos cidadãos, dispensando-se, assim, a formalidade da ratificação individual.

Embora pareça sedutora a idéia de que poderiam existir convenções internacionais do trabalho que dispensariam um ato formal de ratificação, por ostentarem a natureza de jus cogens, é mister admitir que o Direito Internacional ainda não atingiu o nível desse reconhecimento.

Com efeito, é patente que a Declaração de 1998 ostenta um caráter meramente exortatório, não tendo sido integrada, como se realizou com a Declaração da Filadélfia, à Constituição da Organização Internacional do Trabalho, o que permitiria a derrogação implícita da sistemática de ratificação contida no seu art. 19, em relação a tais convenções.

Esse fato é ainda reforçado pelo próprio comportamento da Organização Internacional do Trabalho, que, desde o momento em que adotou a Declaração de 1998, vem realizando forte campanha para a ratificação universal dos instrumentos supracitados, tidos como prioritários.

Finalmente, não se verifica na doutrina nenhuma tese favorável à existência, já no atual estágio de desenvolvimento do Direito Internacional, de convenções internacionais do trabalho com natureza de jus cogens. Pelo contrário, a opinião uniforme caminha ainda no sentido de invocar a soberania nacional, sobre a qual sempre repousou a dinâmica das relações internacionais, como um grave empecilho à teoria do jus cogens, ao argumento de que a Organização Internacional do Trabalho não poderia jamais se constituir como um verdadeiro parlamento universal em matéria de legislação sóciolaboral. 
Todavia, é incontestável que a evolução do sistema de proteção internacional de direitos humanos tem relativizado sobremaneira a própria noção de soberania, sendo esta uma tendência irreversível.

É possível que em um futuro próximo, não mais se recorra à soberania estatal como argumento tendente a obstar a aceitação de que as convenções internacionais do trabalho sobre direitos humanos possam ser aplicadas a todos os países membros da Organização Internacional do Trabalho, dispensando-se a sistemática de ratificação para que possam valer, inclusive, como verdadeiras leis no interior de cada Estado.

Nesse sentido, cabe transcrever importante lição de FÁBIO KONDER Comparato, que no epílogo de sua magistral obra A Afirmação Histórica dos Direitos Humanos, traça um roteiro de humanização do mundo, destacando a necessidade da ampliação legislativa da ONU em matéria de direitos humanos, por meio da supressão da necessidade de ratificação individual de convenções com tal conteúdo:

No tocante à organização das diferentes funções internas da ONU, uma medida importante para a ampliação da função legislativa poderia ser adotada em matéria de convenções sobre direitos humanos, votadas pela Assembléia Geral. A aplicação a tais convenções do sistema comum de ratificação individual pelos Estados-Membros representa um anacronismo. Em sua obra fundadora do direito internacional, Grócio salientou que as convenções entre Estados, analogamente aos contratos do direito privado, podem classificar-se em duas grandes espécies: as bilaterais e as multilaterais. As primeiras, disse ele, dirimunt partes, isto é, separam os interesses próprios das partes contratantes, ao passo que as segundas commuionem adferunt, vale dizer, criam relações de comunhão. Ora, esse objetivo comunitário é mais acentuado no caso de convenções multilaterais votadas no seio de uma organização internacional, cujas decisões, tal como no âmbito das sociedades ou associações do direito privado, são normalmente tomadas por votação majoritária e não por unanimidade. $\mathrm{O}$ argumento de que a assinatura de um tratado internacional, ou de adesão a ele, é ato do Estado e não simplesmente do governo não colhe no caso, pois o ingresso do Estado na organização internacional já foi objeto de ratificação pelo seu Parlamento, e esta implicou, obviamente, a aceitação de suas regras constitutivas.

É de inteira justiça, portanto, que a aprovação de convenções sobre direitos humanos seja incluída na categoria de assuntos a serem decididos por uma maioria de dois terços, referidos no art. 18, terceira alínea, da Carta das Nações Unidas, dispensando-se no caso a ratificação individual dos Estados-Membros para sua entrada em vigor. $^{332}$

${ }^{332}$ Op. cit., p. p. 547-548. 
Tais observações, a despeito de se referirem à ONU, mostram-se totalmente pertinentes também à Organização Internacional do Trabalho, não apenas por ostentar ela, desde 1946, a condição de organismo especializado das Nações Unidas, mas por realizar uma significativa produção de normas internacionais de direitos humanos. Diferentemente da ONU, como já salientado alhures, a Organização Internacional do Trabalho já caminhou no sentido apontado por Fábio Konder Comparato, quando da aprovação da "Declaração sobre Princípios e Direitos Fundamentais no Trabalho" de 1998.

\section{A Hierarquia das Convenções Internacionais do Trabalho no}

\section{SiSTEMA JURÍDICO BRASILEIRO}

\section{1. A Hierarquia dos Tratados em Geral}

No que concerne à posição hierárquica dos tratados na ordem jurídica nacional, é da tradição constitucional brasileira não estatuir, de maneira clara e inequívoca, regras para o disciplinamento da matéria. Isso faz com que a doutrina e a jurisprudência, sobretudo, aquela emanada do Supremo Tribunal Federal, desempenhem papel importante na construção de soluções para os problemas que se colocam em face de tal questão.

Ainda sob a égide da Constituição Federal de 1967, o Supremo Tribunal Federal abandonou seu entendimento segundo o qual as normas de Direito Internacional detinham maior estatura hierárquica do que as normas internas ${ }^{333}$, passando a acolher a tese de que todos os tratados internacionais, independentemente de sua natureza, teriam a mesma hierarquia jurídica que as leis federais. Tal posição foi consolidada no paradigmático acórdão prolatado no Recurso Especial n. 80.004/SE, cujo relator foi o Ministro Xavier de Albuquerque.

Mencionado acórdão examinou a questão do conflito entre a Lei n. 427/69 e a Lei Uniforme de Genebra sobre Letras de Câmbio, tendo tornado-se uma verdadeira referência sobre o estudo do relacionamento entre o Direito Internacional e o Direito interno, sobretudo, em razão das divergências de posicionamento entre os Ministros.

\footnotetext{
${ }^{333}$ Segundo VALÉRIO DE OLIVEIRA MAZZUOLI, tal tese, alicerçada na teoria monista internacionalista radical, teria prevalecido na Suprema Corte brasileira até 1977. In op. cit. (Direitos Humanos...), p. 85.
} 
O voto vencido do relator revelou seu comprometimento com a teoria monista internacionalista radical, ao defender o primado das fontes de direito internacional sobre as de direito interno. Com base nas lições de Haroldo Valadão, para quem a norma internacional teria sua forma própria de revogação - a denúncia -, só podendo ser alterada por outra norma de categoria igual ou superior, internacional ou supranacional, e jamais pela inferior, interna ou nacional, concluiu o eminente Ministro que:

(...) a Lei n. 427, de 1969, e seu decreto de regulamentação, como lei ordinária, não se podem sobrepor à Convenção de Genebra, que estatui expressamente os requisitos legais e formalmente essenciais de que as letras de câmbio e notas promissórias se devem revestir e postergou, explícita e implicitamente, a cominação de nulidade para os que ostentaram na cártula obrigações tipicamente fiscais. ${ }^{334}$

Os demais Ministros, porém, posicionaram-se favoráveis à tese monista internacionalista moderada (que como já visto alhures, não difere substancialmente do chamado dualismo moderado ${ }^{335}$ ) e ao entendimento de que os tratados ostentariam o mesmo status das leis ordinárias, sendo emblemático nesse sentido o voto do eminente Ministro CORDEIRO GUERRA, que, arrimado na doutrina de Alfred von Verdross, entendeu que:

(...) mau grado a primazia do Direito Internacional em relação ao Direito Interno, em caso de conflito entre um e outro direito, a Justiça está vinculada à observância da lei interna pois é órgão de uma ordem jurídica que lhe prescreve a obrigação de aplicar as normas editadas na conformidade do direito próprio ao sistema estatal a que pertence". Sob esse prisma, seguiu afirmando o eminente Ministro que "mesmo no caso em que a Constituição manda incorporar ao direito interno as normas de direito internacional ou as disposições dos tratados, a recepção do Direito Internacional no quadro do direito interno não significa que o Corpo Legislativo fique impedido de editar novas leis contrárias ao disposto nos tratados. O único efeito da recepção do direito internacional no quadro do direito interno é de dar força de lei às normas jurídicas assim incorporadas à legislação. Neste caso, os tratados valerão como lei e nesta qualidade serão aplicados pelos Tribunais, da mesma maneira, na mesma extensão e com a mesma obrigatoriedade próprias à aplicação do direito interno. ${ }^{336}$

${ }^{334}$ RE - 8.004-SE, rel. Min. Xavier De Albuquerque, julgado em 1.06.77, publicado no DJU em 29.12.1977.

${ }^{335}$ A respeito, confira-se o item 1.3 deste Capítulo.

${ }^{336}$ RE - 8.004-SE, rel. Min. XAVIER DE Albuquerque, julgado em 1.06.77, publicado no DJU em 29.12.1977. 


\section{E concluiu:}

(...) argumenta-se que a denúncia é o meio próprio de revogar um tratado internacional. Sim, no campo do direito internacional, não, porém, no campo do direito interno. Quando muito, poderá, face à derrogação do tratado por lei federal posterior, ensejar reclamação de uma outra parte contratante perante o governo, sem contudo afetar as questões de direito interno. Fosse a denúncia internacional o único meio de nulificar um tratado, e não se compreenderia pudesse o Supremo Tribunal Federal negar-lhe validade por vício de inconstitucionalidade. ${ }^{337}$

A tese encimada enraizou-se fortemente no plano jurisprudencial, repercutindo também na esfera doutrinária, principalmente, dentre alguns autores constitucionalistas tradicionais. ${ }^{338}$ E mesmo após o advento da Constituição Federal de 1988, imperou, até recentemente, no âmbito da Suprema Corte, em relação a todas as modalidades de instrumentos internacionais, como se percebe do fragmento a seguir transcrito.

Com efeito, é pacífico na jurisprudência desta Corte que os tratados internacionais ingressam em nosso ordenamento jurídico tão somente com força de lei ordinária (o que ficou ainda mais evidente em face de o artigo 105, III, da Constituição que capitula, como caso de recurso especial a ser julgado pelo Superior Tribunal de Justiça como ocorre com relação à lei infraconstitucional, a negativa de vigência de tratado ou a contrariedade a ele), não se lhes aplicando, quando tendo eles integrado nossa ordem jurídica posteriormente à Constituição de 1988 , o disposto no artigo $5^{\circ}$, § $2^{\circ}$, pela singela razão de que não se admite emenda constitucional realizada por meio de ratificação de tratado. (Grifos ausentes no texto original). ${ }^{339}$

${ }^{337}$ RE - 8.004-SE, rel. Min. XAVIER De Albuquerque, julgado em 1.06.77, publicado no DJU em 29.12.1977.

${ }^{338}$ Nesse sentido veja-se MANOel GonÇAlves FerreIRA Filho, Direito Humanos Fundamentais, São Paulo, Saraiva, 1995, p. 98.

${ }^{339}$ HC 72.131, rel. Min. MoreIRA ALVES, julgado em 23.11.1995, publicado no DJU em 1.8.2003. 


\section{2. A Hierarquia dos Tratados de Direitos Humanos}

\subsubsection{A Visão da Moderna Doutrina Constitucionalista e a Mudança de}

Posição adotada pelo Supremo Tribunal Federal

A Constituição Federal de 1988, de maneira inédita, consagrou em seu art. $5^{\circ}, \S 2^{\circ}$, que "os direitos e garantias fundamentais nela previstos não excluem outros decorrentes do regime e dos princípios por ela adotados, ou dos tratados em que a República Federativa do Brasil seja parte”. (Grifos inexistentes no texto original).

O preceptivo constitucional em tela foi proposto à Assembléia Nacional Constituinte por AnTôNiO Augusto CANÇADO TRINDAdE ${ }^{340}$, razão pela qual merece especial relevo a sua interpretação sobre o citado parágrafo.

Nas palavras do insigne jurista:

(...) a disposição do artigo $5^{\circ}$ (2) da Constituição Brasileira vigente, de 1988, segundo a qual os direitos e garantias nesta expressos não excluem outros decorrentes dos tratados internacionais em que o Brasil é parte, representa, a meu ver, um grande avanço para a proteção dos direitos humanos em nosso país. Por meio deste dispositivo constitucional, os direitos consagrados em tratados de direitos humanos em que o Brasil seja parte incorporam-se ipso jure ao elenco dos direitos constitucionalmente consagrados. Ademais, por força do artigo $5^{\circ}$ (1) da Constituição, têm aplicação imediata. A intangibilidade dos direitos e garantias individuais é determinada pela própria Constituição Federal, que inclusive proíbe expressamente até mesmo qualquer emenda tendente a aboli-los (artigo 60 (4) (IV)). A especificidade e o caráter especial dos tratados de direitos humanos encontramse, assim, devidamente reconhecidos pela Constituição Brasileira vigente. (...) Por conseguinte, mostra-se inteiramente infundada, no tocante em particular aos tratados de direitos humanos, a tese clássica - ainda seguida em nossa prática constitucional - da paridade entre os tratados internacionais e a legislação infraconstitucional. (...) É esta interpretação correta do artigo $5^{\circ}$ (2) da Constituição Brasileira vigente, que abre um campo amplo e fértil para avanços nesta área, ainda lamentavelmente e em grande parte desperdiçado. Com efeito, não é razoável dar aos tratados de proteção de direitos do ser humano (a começar pelo direito fundamental à vida) o mesmo tratamento dispensado, por exemplo, a um acordo comercial de exportação de laranjas ou sapatos, ou a um acordo comercial de exportação de laranjas ou sapatos, ou a um acordo de isenção de vistos para

${ }^{340}$ A Proteção Internacional dos Direitos Humanos e o Brasil (1948-1997) - As Primeiras Cinco Décadas, Brasília, UNB, 1998, p. p. 163-176. 
turistas estrangeiros. A hierarquia de valores, deve corresponder uma hierarquia de normas, nos planos tanto nacional quanto internacional, a ser interpretadas e aplicadas mediante critérios apropriados. Os tratados de direitos humanos têm caráter especial e, devem ser tidos como tais. Se maiores avanços não se têm logrado até o presente neste domínio de proteção, não tem sido em razão de obstáculos jurídicos - que na verdade não existem -, mas antes da falta de compreensão da matéria e da vontade de dar real efetividade àqueles tratados no plano do direito interno. ${ }^{341}$

As lições de Antônio Augusto Cançado Trindade ressoaram sobre a moderna doutrina constitucionalista nacional, dando ensejo a entendimentos segundo os quais concorreriam, no sistema jurídico nacional, dois regimes distintos no que respeita à problemática da hierarquia dos tratados já incorporados: um específico aos tratados de direitos humanos, que gozariam de envergadura constitucional; outro aplicável aos tratados comuns, que possuiriam status inferior às normas constitucionais.

Flávia Piovesan, uma das mais notáveis defensoras da tese de que os tratados de direitos humanos teriam estatura constitucional, constrói seu entendimento tendo por alicerce além da doutrina de Cançado Trindade, também as valiosas lições de Konrad Hesse e José Joaquim Gomes Canotilho.

Afirma a mencionada autora que o $\S 2^{\circ}$ do art. $5^{\circ}$ da Constituição Federal trata-se de uma cláusula constitucional aberta que tem sua existência justificada em razão do próprio caráter da Constituição, que "ao estabelecer diretrizes e linhas básicas, (...) não detém a pretensão de completude. A incompletude da Carta aponta para sua abertura, o que permite a flexibilidade necessária ao contínuo desenvolvimento político". ${ }^{342}$ Explica, ainda, que, por meio do aludido $\S 2^{\circ}$, que deve ser analisado sob a luz do princípio da máxima efetividade das normas constitucionais, é possível a inclusão dos direitos humanos enunciados nos tratados internacionais em que o Brasil seja parte no catálogo de direitos constitucionalmente protegidos. Por essa razão, não haveria como negar que um tratado internacional com tal conteúdo, ao integrar-se ao sistema jurídico, assumiria a mesma posição hierárquica das demais normas constitucionais consagradoras de direitos fundamentais. E arremata, afirmando que "essa conclusão advém ainda de interpretação sistemática e teleológica do Texto, especialmente em face da força expansiva dos valores

\footnotetext{
341 Antônio Augusto CançAdo Trindade, Memorial em Prol de uma Nova Mentalidade quanto à Proteção dos Direitos Humanos nos Planos Internacional e Nacional in CELSO D. DE ALBUQUERQUE MELLO e RiCARDo Lobo (diretores), Arquivos de Direitos Humanos, vol. 1, Rio de Janeiro, Renovar, 1999, p. p. 4647.

${ }^{342}$ Flávia Piovesan, op. cit. (Direitos Humanos e o Direito Constitucional Internacional...), p. 56.
} 
da dignidade humana e dos direitos fundamentais, como parâmetros axiológicos a orientar a compreensão do fenômeno constitucional". 343

Outro expoente da moderna doutrina constitucionalista nacional a defender a corrente da hierarquia constitucional dos tratados de direitos humanos é INGO WOLFGANG SARLET. Citado autor parte da diferenciação entre direitos formalmente fundamentais e direitos materialmente fundamentais como mecanismo auxiliar da interpretação do art. $5^{\circ}$, $\S 2^{\circ}$, da Constituição da República. Amparado pelas lições de Robert Alexy e José Joaquim Gomes Canotilho, explica que intrínseca à noção de direitos fundamentais se encontra a característica da fundamentalidade, a qual aponta para a especial dignidade de proteção dos direitos em um sentido formal e em um sentido material. A fundamentalidade formal ligase ao direito constitucional positivo e, portanto, à idéia de constituição escrita. Já a noção da fundamentalidade material vincula-se à circunstância dos direitos fundamentais serem "elemento constitutivo da Constituição material, contendo decisões fundamentais sobre a estrutura básica do Estado e da sociedade". Por meio dessa última nota, é possível admitirse a existência de direitos fundamentais não constantes do texto constitucional, mas que, por seu conteúdo, integram o chamado bloco material de constitucionalidade, por meio da cláusula de abertura expressamente consagrada no art. $5^{\circ}, \S 2^{\circ}$ da Constituição Federal. ${ }^{344}$

Com fulcro nos destacados argumentos, conclui INGo WolfGANG SARLET que:

(...) a tese da equiparação (por força do disposto no art. $5^{\circ}, \S 2^{\circ}$, da CF) entre os direitos fundamentais localizados em tratados internacionais e os com sede na Constituição formal é a que mais se harmoniza com a especial dignidade jurídica e axiológica dos direitos fundamentais na ordem jurídica interna e internacional, constituindo, ademais, pressuposto indispensável à construção e consolidação de um autêntico direito constitucional internacional dos direitos humanos, resultado da interpenetração cada vez maior entre os direitos fundamentais constitucionais e os direitos humanos dos instrumentos jurídicos internacionais. No mínimo, contudo, para preservar sua condição específica de direitos

\footnotetext{
${ }^{343}$ Op. cit. (Direitos Humanos e o Direito Constitucional Internacional...), p. 52. No que tange aos tratados internacionais cujo conteúdo não seja ligado a direitos humanos (tratados comuns ou tradicionais), a posição da citada jurista também diverge daquela majoritariamente defendida no âmbito jurisprudencial. Para ela o status infraconstitucional desses instrumentos adviria do disposto no art. 102, III, $b$, da Constituição Federal, que fixa a competência do Supremo Tribunal Federal para o julgamento, em recurso extraordinário, das causas decididas em última ou única instância, quando a decisão recorrida declarar a inconstitucionalidade de tratado e lei federal. Já a estatura supralegal surgiria do princípio da boa-fé, vigente no direito internacional (o pacta sunt servanda), e que tem como reflexo o art. 27 da Convenção de Viena, segundo o qual não cabe ao Estado invocar disposições de seu direito interno como justificativa para o não-cumprimento de tratado. In op. cit. (Direitos Humanos e o Direito Constitucional Internacional...), p. 60.

${ }^{344}$ Op. cit., p. p. 88-89.
} 
materialmente fundamentais e não remetê-los a um plano idêntico às leis ordinárias, há que admitir (a exemplo do que entende a doutrina majoritária em Portugal, não obstante sucumbente entre nós) sua supremacia com relação ao direito interno infraconstitucional. ${ }^{345}$

Mencionadas lições doutrinárias alimentaram novos debates na esfera jurisprudencial. No Supremo Tribunal Federal, em que pese a prevalência da tese da equiparação dos tratados às leis ordinárias no acórdão proferido nos autos do $\mathrm{HC}-72.131$ - RJ, sobre prisão civil de depositário infiel, o eminente Ministro CARLOS Velloso, proferiu voto no qual sustenta, ao comentar o art. $7^{\circ}$, item 7 , da Convenção Americana sobre Direitos Humanos, a estatura constitucional dos tratados de direitos humanos, conforme se extrai do excerto a seguir colacionado.

São três as vertentes na Constituição de 1988, dos direitos e garantias: a) direitos e garantias expressos na Constituição; b) direitos e garantias decorrentes do regime e dos princípios adotados pela Constituição; c) direitos e garantias inscritos nos tratados internacionais firmados pelo Brasil (art. $\left.5^{\circ}, \S 2^{\circ}\right)$.

Se é certo que, na visualização dos direitos e garantias, é preciso distinguir, mediante o estudo da teoria geral dos direitos fundamentais, os direitos fundamentais materiais dos direitos fundamentais puramente formais (...), não é menos certo, entretanto, que, no caso, estamos diante de direito fundamental material, que diz respeito à liberdade. Assim, a Convenção de São José da Costa Rica, no ponto, é vertente de direito fundamental. É dizer, o direito assegurado no art. $7^{\circ}$, item 7 , da citada Convenção, é um direito fundamental, em pé de igualdade com os direitos fundamentais expressos na Constituição. ${ }^{346}$

Em decisão ainda mais recente, a Suprema Corte nacional posicionou-se favoravelmente à tese de que os tratados internacionais de direitos humanos recepcionados pelo Direito brasileiro teriam um status normativo superior às leis federais, embora, não tenha o Excelso Tribunal abraçado integralmente as teses doutrinárias supracitadas, por não reconhecer a referidos instrumentos convencionais o grau de normas constitucionais. A evolução jurisprudencial destacada deu-se nos autos do Habeas Corpus n. 90.172-7, que teve como relator o eminente Ministro GILMAR MEndES. Na fundamentação de seu voto, reiterou o referido Ministro os mesmos argumentos por ele defendidos no RE $n$. 466.343/SP - cujo julgamento, até a presente data, não se ultimou -, da seguinte forma:

\footnotetext{
${ }^{345}$ Op. cit., p. 147.

${ }^{346} \mathrm{HC}-72.131$, rel. Min. MOREIRA ALVES, julgado em 23.11.95, publicado em 1.08.2003.
} 
Entendo que, desde a ratificação, pelo Brasil, sem qualquer reserva, do Pacto Internacional dos Direitos Civis e Políticos (art. 11) e da Convenção Americana sobre Direitos Humanos - Pacto de San José da Costa Rica (art. 7º 7), ambos no ano de 1992, não há mais base legal para prisão civil do depositário infiel, pois o caráter especial desses diplomas internacionais sobre direitos humanos lhes reserva lugar específico no ordenamento jurídico, estando abaixo da Constituição, porém acima da legislação interna. O status normativo supralegal dos tratados internacionais de direitos humanos subscritos pelo Brasil, dessa forma, torna inaplicável a legislação infraconstitucional com ele conflitante, seja ela anterior ou posterior ao ato de ratificação. (...)

Deixo acentuado, também, que a evolução jurisprudencial sempre foi uma marca de qualquer jurisdição de perfil constitucional. A afirmação da mutação constitucional não implica o reconhecimento, por parte da Corte, de erro ou equívoco interpretativo do texto constitucional em julgados pretéritos. Ela reconhece e reafirma, ao contrário, a necessidade da contínua e paulatina adaptação dos sentidos possíveis da letra da Constituição aos câmbios observados numa sociedade que, como a atual, está marcada pela complexidade e pelo pluralismo. ${ }^{347}$ (Grifos ausentes no documento original).

A despeito do pequeno avanço da tese do Supremo Tribunal Federal, traduzida pelo fragmento supra transcrito, não há como encampá-la diante de uma análise sistemática do ordenamento jurídico nacional com esteio no valor supremo da dignidade da pessoa humana e nos demais princípios do sistema dos direitos humanos. Todavia, é mister reconhecer sua importância em virtude de ter sido consolidada em um momento posterior às mudanças introduzidas pela Emenda Constitucional n. 45/04 (a seguir analisadas), e, ainda assim, ter deixado transparecer que o entendimento da Suprema Corte relativo à hierarquia diferenciada dos tratados de direitos humanos no ordenamento brasileiro adviria, sobretudo, do caráter especial desses diplomas e não, propriamente, de aspectos relacionados à sua forma de integração.

\subsubsection{As Conseqüências da Emenda Constitucional n. 45/04 no Tocante à}

\section{Hierarquia dos Tratados de Direitos Humanos}

Já se advertiu, em linhas pretéritas, que o $§ 3^{\circ}$, do art. $5^{\circ}$, da Constituição Federal, fruto da Emenda Constitucional n. 45/04, teria sido concebido como solução ao

${ }^{347}$ HC 90.172, Rel. Min. GILMAR MENDES, julgado em 5.6.07, publicado no DJU em 17.08.2007. 
grande dissenso doutrinário e jurisprudencial relativo à questão da integração das normas internacionais consagradoras de direitos humanos (principalmente, no tangente ao aspecto da posição desses instrumentos na hierarquia normativa nacional), mas que longe de criar uma harmonia de opiniões, gerou ainda mais celeumas.

Indubitavelmente, o intento do legislador constituinte derivado foi o de acentuar que o maior relevo material dos instrumentos convencionais de direitos humanos em relação aos demais tratados deveria corresponder também à adoção de um regime de proteção e aplicação diferenciado aos primeiros, por meio do reconhecimento de um status normativo compatível ao conteúdo deles: o patamar de normas constitucionais. Tal consequiência já vinha amplamente sido admitida pela doutrina, como decorrência de uma exegese teleológica do comando expresso no art. $5^{\circ}, \S 2^{\circ}$. No plano da jurisprudência, todavia, essa posição vinha sendo rechaçada sob os mais diversos argumentos, avultando, como um de seus principais, o fato de não se admitir alterações na Constituição, senão por meio do processo formal de emendas.

$\mathrm{O}$ advento do novel $\S 3^{\circ}$ procurou, aparentemente, ir ao encontro das proposições doutrinárias que sustentavam a natureza constitucional dos tratados de direitos humanos incorporados ao sistema jurídico pátrio, sem, contudo, voltar completamente as costas a algumas objeções freqüentemente lançadas na esfera jurisprudencial sobre a impossibilidade de se conferir tal envergadura a esses instrumentos (sobretudo, àquela supra apontada). Em outros termos, a redação do aludido dispositivo revela uma tentativa de por fim às controvérsias, pela adoção de uma proposta conciliatória entre a tese doutrinal e a antítese jurisprudencial.

Passados, aproximadamente, quatro anos da reforma constitucional, não se verificou, entretanto, o equacionamento das questões que já constituíam a pauta de discussões da Ciência e prática jurídicas no panorama pré-emenda n. 45/04 e, ainda por cima, novas indagações advieram em virtude das inovações trazidas.

A corrente doutrinária que advogava a tese segundo a qual o status constitucional dos tratados de direitos humanos decorreria do contido no art. $5^{\circ}, \S 2^{\circ}$, da Constituição Federal dividiu-se em, pelo menos, três posições discrepantes no que tange à interpretação que conferem ao novo $\S 3^{\circ}$ do art. $5^{\circ}$.

Para GEORGe RodRigo BANDEIRA GALINDO, o acréscimo do $\S 3^{\circ}$ ao art. $5^{\circ}$ da Constituição Federal pode suscitar alguns resultados deletérios, representando, pois, um 
verdadeiro retrocesso para a proteção dos direitos humanos e fundamentais no Brasil, que poderia ser identificado "não a partir da jurisprudência do Supremo Tribunal Federal, mas a partir das possibilidades interpretativas oferecidas pelo Artigo $5^{\circ}, \S 2^{\circ}$ ".$^{348}$

Segundo o mencionado jurista, a estatura constitucional dos direitos fundamentais previstos em tratados internacionais decorreria da cláusula de abertura da Constituição, expressa pelo citado $\S 2^{\circ}$, que, por sua vez, não permitiria qualquer diferenciação destes em relação aos direitos que foram consagrados originariamente no Texto Constitucional. Com efeito, não existiriam, para o autor, indícios na redação do art. $5^{\circ}, \S 2^{\circ}$, que levassem a crer que "o Constituinte de 1988 tenha querido que os tratados de direitos humanos se incorporassem como emendas constitucionais". A distinção entre uma norma equivalente a um dispositivo original da Constituição e uma norma equivalente a uma emenda constitucional, embora sutil, torna-se substancial no tocante às soluções apresentadas para hipóteses de colisões entre os direitos por elas previstos. Isso porque as emendas à Constituição, como fruto do Poder Constituinte Derivado, sujeitam-se a um controle de constitucionalidade quando seu conteúdo chocar-se com alguma cláusula pétrea. Porém, em se tratando de direitos consagrados na Constituição pelo mesmo legislador constituinte, a unidade do sistema jurídico é preservada não por um critério de anulação de normas, mas de ponderação dos interesses (valores) em pauta. ${ }^{349}$

Desse modo, seria lícito concluir que a equiparação dos tratados de direitos humanos às emendas poderia suscitar a submissão desses diplomas a um controle de constitucionalidade, mesmo na hipótese em que suas disposições mostrarem-se mais favoráveis à garantia da dignidade da pessoa humana, mas contrárias a um dispositivo constante originalmente no catálogo constitucional de direitos fundamentais (como, por exemplo, na hipótese da prisão civil do depositário infiel). Em contrapartida, pela tese da equivalência das normas internacionais de direitos humanos com as normas constitucionais originais, em um caso de colisão entre elas, sempre seria possível uma exegese dirigida à prevalência do valor fundante da dignidade humana.

Em direção contrária, FLÁVIA PIOVESAN, procura enxergar o novel parágrafo como uma inovação positiva, por explicitar e, desse modo, reforçar o entendimento de que os tratados possuem uma hierarquia constitucional. Nesse sentido, valendo-se das lições de Celso Lafer, referida autora considera tal preceptivo como,

\footnotetext{
${ }^{348}$ Op. cit., p. 97.

${ }^{349}$ GEORGE RODRIGO BANDEIRA GALINDO , op. cit., p. p. 90-92.
} 
essencialmente, uma lei interpretativa destinada a por fim aos embates suscitados em torno do art. $5^{\circ}, \S 2^{\circ}$. Argumenta que, tendo em vista essa última disposição, todos os tratados de direitos humanos já seriam materialmente constitucionais, compondo o bloco de constitucionalidade. Dessa forma, não seria propriamente a regra existente no $\S 3^{\circ}$, que exige um quorum qualificado de aprovação desses instrumentos, quem conferiria tal natureza a eles. Todavia, o novo parágrafo reforçaria essa qualidade, "ao adicionar um lastro formalmente constitucional aos tratados ratificados, propiciando a 'constitucionalização formal' dos tratados de direitos humanos no âmbito jurídico interno". 350

Prossegue a insigne jurista asseverando que todos os tratados de direitos humanos ratificados anteriormente à Emenda n. 45/2004 são, por força dos $\S \S 2^{\circ}$ e $3^{\circ}$ do art. $5^{\circ}$, normas materialmente e formalmente constitucionais, porém, com relação aos instrumentos convencionais que forem integrados após a citada Emenda, estes serão sempre normas materialmente constitucionais, mas somente ostentarão a qualidade de normas formalmente constitucionais se percorrerem todo o iter procedimental demandado pelo $\S 3^{\mathrm{o}}{ }^{351} \mathrm{Em}$ termos mais singelos, parece ter a autora encampado a tese de que o indigitado preceptivo teria uma eficácia retroativa, ao reconhecer também a constitucionalização formal dos tratados ratificados anteriormente à Reforma, apesar de não terem, obviamente, sido aprovados pelo procedimento parlamentar equivalente ao da aprovação das Emendas. ${ }^{352}$

Finalmente, conclui pela possibilidade, a partir da introdução do $\S 3^{\circ}$ ao art. $5^{\circ}$ da Constituição Federal, do surgimento de duas categorias de tratados internacionais de direitos humanos: os materialmente e formalmente constitucionais; e os apenas materialmente constitucionais. A essas duas categorias, aplicar-se-iam regimes jurídicos

\footnotetext{
${ }^{350}$ Op. cit. (Direitos Humanos e o Direito Constitucional Internacional...), p. p. 72-73.

${ }^{351}$ Flávia PIOVESAN, op. cit. (Direitos Humanos e o Direito Constitucional Internacional...), p. p. 73-74.

${ }^{352}$ A favor da eficácia retroativa do $\S 3^{\circ}$ do art. $5^{\circ}$ da Constituição Federal, PAULO RICARDO SCHIER propõe a aplicação do princípio do tempus regit actum, amplamente aceito pelo Supremo Tribunal Federal para a recepção como leis complementares das tributárias aprovadas anteriormente à Constituição de 1967. Não obstante a defesa dessa tese, o próprio autor reconhece a sua fragilidade, argumentando que ela problematicamente transporta um princípio de direito infraconstitucional para a compreensão de enunciado constitucional. In Hierarquia Constitucional dos Tratados Internacionais de Direitos Humanos e EC 45 Tese em Favor da Incidência do Tempus Regit Actum, diponível em: http://www.conpedi.org/manaus/ arquivos/Anais/Paulo\%20Ricardo\%20Schier.pdf. Acesso em 14/10/2008.
} 
distintos no que tange à denúncia desses instrumentos (aspecto que será retomado no tópico subseqüente). ${ }^{353}$

Muito próximo à posição adotada por Flávia Piovesan, encontra-se o entendimento de INGo WolfGang SARLET, para quem o $\S 3^{\mathrm{a}}$ do art. $5^{\circ}$ da Constituição Federal

(...) acabou por inserir no texto constitucional uma norma procedimental dispondo sobre a forma de incorporação ao direito interno dos tratados em matéria de direitos humanos, que, interpretada em sintonia com o artigo $5^{\circ}, \S 2^{\circ}$, pode ser compreendida como assegurando em princípio e em sendo adotado tal procedimento - a condição de direitos formal, e materialmente constitucionais (e fundamentais) aos direitos consagrados no plano das convenções internacionais. ${ }^{354}$

Nesse sentido, sustenta INGo WolfGAng SARLET que a inovação representaria um avanço até mesmo à doutrina que propugnava o reconhecimento das normas convencionais de direitos humanos como materialmente constitucionais. Além disso, fazendo clara alusão à tese jurisprudencial reinante anteriormente à Emenda Constitucional n. 45/04, argumenta que tal preceptivo também teria um "potencial positivo, no sentido de viabilizar alguns avanços concretos em relação à práxis ora vigente entre nós". 355

Este último autor, contrariamente ao entendimento esposado por Flávia Piovesan, questiona a tese de que por força da Emenda Constitucional n. 45/04 todos os tratados de direitos humanos já incorporados ao sistema jurídico nacional poderiam ser considerados como equivalentes às emendas constitucionais. Para ele, não seria possível aplicar neste caso o argumento da recepção, em face da existência de procedimentos legislativos distintos, não sendo admissível, ainda que houvesse compatibilidade material, transmutar um decreto legislativo, aprovado pela maioria simples do Congresso Nacional em emenda constitucional, que exige uma maioria qualificada de três quintos dos votos e

\footnotetext{
${ }^{353}$ Flávia PiovesAn, op. cit. (Direitos Humanos e o Direito Constitucional Internacional...), p. p. 74-75.

${ }^{354}$ Op. cit., p. 150.

355 Op. cit., p. p. 160-161.
} 
dois turnos de votação. Destarte, segundo seu entendimento, a constitucionalidade formal seria alcançável somente com o percurso do rito estabelecido no novo $\S 3^{\circ}{ }^{356}$

Por derradeiro, INGo WolfGAng SARLET, supera a crítica apresentada por George Rodrigo Bandeira Galindo, segundo a qual o comando do $\S 3^{\circ}$ implicaria um retrocesso na proteção dos direitos humanos sediados em tratados, tendo em vista que em uma eventual situação de colisão entre estes (equivalentes a emendas constitucionais) e direitos fundamentais consagrados no texto original da Constituição, a solução seria a invalidação dos primeiros, mediante o mecanismo de controle de constitucionalidade a que estão submetidas as emendas, ainda que mais favoráveis à garantia da dignidade da pessoa. Expõe INGO WolfGang SARLET, que o novel parágrafo chancela a tese de que todos os direitos fundamentais (incorporados, ou não, por emenda constitucional) possuem status materialmente constitucional. Desse modo, afirma que na seara dos direitos fundamentais:

(...) eventual situação conflitiva (mesmo em se cuidando de contraste entre emenda e disposições fundamentais da Constituição originária) haveria de se resolver, até mesmo para impedir um tratamento incoerente e inconsistente de tais conflitos no âmbito do sistema constitucional, pelas mesmas diretrizes hermenêuticas, tendo como norte a solução mais afinada com a máxima salvaguarda da dignidade da pessoa humana (...). ${ }^{357}$

No plano jurisprudencial, não se verificou ainda ter o Supremo Tribunal Federal se manifestado sobre a questão. Mesmo o recente acórdão proferido nos autos do HC n. 90172-7 (que reconheceu um status supralegal aos tratados de direitos humanos), passou ao largo da problemática suscitada pelo $\S 3^{\circ}$ do art. $5^{\circ}$, não fazendo qualquer menção expressa ao novel dispositivo. Todavia, a matéria já chegou ao Superior Tribunal de Justiça, sendo alvo de profunda contenda.

De um lado, perfilham-se os entendimentos que condicionam a estatura constitucional dos tratados de direitos humanos à sua aprovação pelo procedimento estabelecido pela Emenda Constitucional n. 45/04. Em termos mais claros, esta corrente sustenta que os tratados de direitos humanos aprovados anteriormente à mencionada emenda têm somente a força normativa de leis ordinárias. Tal posição da jurisprudência pode ser extraída da seguinte ementa:

\footnotetext{
${ }^{356}$ INGO WOLFGANG SARLET, op. cit., p. 151.

${ }^{357}$ Op. cit., p. 160.
} 
RECURSO ORDINÁRIO EM HABEAS CORPUS. PRISÃO CIVIL DE DEPOSITÁRIO INFIEL. ALIENAÇÃO DAS COTAS DA SOCIEDADE PELO DEPOSITÁRIO. TRANSFERÊNCIA DO ENCARGO ATRELADA À AUTORIZAÇÃO JUDICIAL. POSSIBILIDADE DE DECRETAÇÃO DA PRISÃO MESMO APÓS O ADVENTO DA EC 45/2004, QUE INTRODUZIU O $\S 3^{\circ}$ NO ART. $5^{\circ}$ DA CONSTITUIÇÃO FEDERAL. PENHORA EM EXECUÇÃO FISCAL. FALÊNCIA SUPERVENIENTE. SÚMULA 305/STJ. NÃO INCIDENTE NA HIPÓTESE DOS AUTOS.

\section{(...)}

4. Quanto aos tratados sobre direitos humanos preexistentes à EC 45/2004, a transformação de sua força normativa - de ordinária para constitucional também supõe a observância do requisito formal da ratificação pelas Casas do Congresso, por quorum, qualificado de três quintos. Tal requisito não foi atendido, até a presente data, em relação ao Pacto de São José da Costa Rica (Convenção Americana de Direitos Humanos). Continua prevalecendo, por isso, o art. $5^{\circ}$, LXVII, da Constituição Federal, que autoriza a prisão civil do depositário infiel.

5. Nos termos do $\S 3^{\circ}$ do art. $5^{\circ}$ da CF (introduzido pela EC 45/2004), 'Os tratados e convenções internacionais sobre direitos humanos que forem aprovados, em cada Casa do Congresso Nacional, em dois turnos, por três quintos dos votos dos respectivos membros, serão equivalentes às emendas constitucionais'. Trata-se de exceção à regra geral segundo a qual os tratados internacionais ratificados pelo Brasil incorporam-se ao direito interno como lei ordinária.(...). ${ }^{358}$ (Grifos ausentes no documento original).

De outro lado, está a corrente jurisprudencial que vislumbra ter o $\S 3^{\circ}$ uma aplicação retroativa, alcançando os tratados de direitos humanos integrados anteriormente à Emenda n. 45/04, para lhes dar força de constitucional, a despeito de terem sido aprovados no Parlamento pelo simples quorum exigido para o Decreto Legislativo. Essa opinião é sintetizada pela ementa a seguir transcrita.

CONSTITUCIONAL. PROCESSUAL PENAL. RECURSO ORDINÁRIO EM HABEAS CORPUS. EXECUÇÃO FISCAL. DEPOSITÁRIO INFIEL. PENHORA SOBRE O FATURAMENTO DA EMPRESA. CONSTRANGIMENTO ILEGAL. EMENDA

358 RHC 19.9475/RS, Rel. Min. TEORI Albino ZAVASCKI, julgado em 21.09.06, publicado no DJU em 05.10.06. 


\section{CONSTITUCIONAL No 45/2004. PACTO DE SÃO JOSÉ DA COSTA RICA. APLICAÇÃO IMEDIATA. ORDEM CONCEDIDA. PRECEDENTES.}

\section{(..)}

5. No atual estágio do nosso ordenamento jurídico, há de se considerar que:

a) a prisão civil de depositário infiel está regulamentada pelo Pacto de São José da Costa Rica, do qual o Brasil faz parte;

b) a Constituição da República, no Título II (Dos Direitos e Garantias Fundamentais), Capítulo I (Dos Direitos e Deveres Individuais e Coletivos), registra no $\S 2^{\circ}$ do art. $5^{\circ}$ que 'os direitos e garantias expressos nesta Constituição não excluem outros decorrentes do regime e dos princípios por ela adotados, ou dos tratados internacionais em que a República Federativa do Brasil seja parte'. No caso específico, inclui-se no rol dos direitos e garantias constitucionais o texto aprovado pelo Congresso Nacional inserido no Pacto de São José da Costa Rica;

c) o $\S 3^{\circ}$ do art. $5^{\circ}$ da $\mathrm{CF} / 88$, acrescido pela $\mathrm{EC} \mathrm{n}^{\circ} 45$, é taxativo ao enunciar que 'os tratados e convenções internacionais sobre direitos humanos que forem aprovados, em cada Casa do Congresso Nacional, em dois turnos, por três quintos dos votos dos respectivos membros, serão equivalentes às emendas constitucionais'. Ora, apesar de à época o referido Pacto ter sido aprovado com quorum de lei ordinária, é de se ressaltar que ele nunca foi revogado ou retirado do mundo jurídico, não obstante a sua rejeição decantada por decisões judiciais. De acordo com o citado $\S 3^{\circ}$, a Convenção continua em vigor, desta feita com força de emenda constitucional. A regra emanada pelo dispositivo em apreço é clara no sentido de que os tratados internacionais concernentes a direitos humanos nos quais o Brasil seja parte devem ser assimilados pela ordem jurídica do país como normas de hierarquia constitucional;

d) não se pode escantear que o $\S 1^{\circ}$ supra determina, peremptoriamente, que 'as normas definidoras dos direitos e garantias fundamentais têm aplicação imediata'. $\mathrm{Na}$ espécie, devem ser aplicados, imediatamente, os tratados internacionais em que o Brasil seja parte;

e) o Pacto de São José da Costa Rica foi resgatado pela nova disposição constitucional (art. $5^{o}, \S 3^{\circ}$ ), a qual possui eficácia retroativa; (...)". (Grifos ausentes no documento original). ${ }^{359}$

Como conclusão, deve-se admitir que dentre as soluções apresentadas, em que pesem as respeitáveis posições de George Rodrigo Bandeira Galindo e Flávia

${ }^{359}$ RHC 18.799/RS, Rel. Min. José DELGADO, julgado em 9.05.06, publicado no DJU em 08.06.06. 
Piovesan, parecem ser as prelações efetuadas por Ingo Wolfgang Sarlet as mais adequadas à conferir uma interpretação aceitável ao $\S 3^{\circ}$ do artigo $5^{\circ}$. Novamente, há que ser feita a devida ressalva de que a matéria é por demais recente e controvertida, carecendo de maior debate e maturação tanto na doutrina como na jurisprudência. Por ora, é possível, pelo menos, rechaçar a tese jurisprudencial que condiciona o status hierárquico dos tratados à forma aplicada à sua aprovação, ou seja, aquela que sustenta terem os tratados aprovados anteriormente à reforma constitucional de 2004, a mesma força normativa das leis ordinárias. Isso porque, todos os tratados de direitos humanos, independentemente da forma pela qual foram aprovados, são materialmente constitucionais por força do art. $5^{\circ}, \S$ $2^{\circ}$, da Carta Política. Não é, portanto, o rito estabelecido pelo $\S 3^{\circ}$ que determina esta natureza. Como bem expõe FLÁVIA PIOVESAN,

(...) na hermenêutica emancipatória dos direitos humanos há que imperar uma lógica material e não formal, orientada por valores, a celebrar o valor fundante da prevalência da dignidade humana. À hierarquia de valores deve corresponder uma hierarquia de normas, e não o oposto. Vale dizer, a preponderância material de um bem jurídico, como é o caso de um direito fundamental, deve condicionar a forma no plano jurídico-normativo, e não ser condicionado por ela. ${ }^{360}$

\subsection{A Hierarquia das Convenções Internacionais do Trabalho}

Como verdadeiros tratados internacionais multilaterais abertos à ratificação, às convenções internacionais do trabalho se aplicam todas as observações lançadas nos dois subitens anteriores. Dessa forma, em conformidade com a classificação apresentada no capítulo III desta dissertação, as convenções internacionais do trabalho sobre direitos humanos integradas ao sistema jurídico brasileiro gozam da estatura de normas materialmente constitucionais.

Vale ressaltar que a até a presente data, nenhuma convenção da Organização Internacional do Trabalho foi incorporada no país sob a égide do novel $\S 3^{\circ}$ do art. $5^{\circ}$ da Constituição Federal, razão pela qual inexistem diplomas dessa natureza que sejam

\footnotetext{
${ }^{360}$ Op. cit. (Direitos Humanos e o Direito Constitucional Internacional...), p. 72.
} 
materialmente e formalmente constitucionais, ou seja, que sob o ponto de vista formal, equivalham às emendas constitucionais.

Em relação às convenções internacionais do trabalho ratificadas pelo Brasil que não se qualificam como tratados de direitos humanos é mister reconhecer que não possuem a mesma envergadura das normas constitucionais, podendo-se sustentar, quando muito, um caráter infraconstitucional mas supralegal desses diplomas, como acertadamente o faz Flávia PiOVESAN, tendo por base o princípio da boa-fé internacional e o disposto no art. 27 da Convenção de Viena sobre Direito dos Tratados. ${ }^{361}$

\section{A DENÚNCIA DAS CONVENÇÕES INTERNACIONAIS DO TrabaLHO}

\subsection{Princípios e Condições Aplicáveis à Denúncia dos Tratados em}

\section{Geral}

A denúncia é um ato unilateral do Estado, pelo qual este manifesta sua vontade de deixar de ser parte em um determinado acordo internacional. Mencionado instituto é instrumento hábil a por fim aos tratados bilaterais, mas insuficiente a determinar a extinção dos instrumentos multilaterais, cuja vigência internacional segue normalmente inabalada com a retirada de um ou mais Estados.

Há tratados que, por sua própria natureza, não permitem a denúncia. Tal ocorre, segundo José FRANCISCO REZEK, com os chamados tratados reais, dispositivos ou de vigência estática, v.g., os tratados de fronteiras, pelo qual dois Estados acertam a linha divisória entre seus territórios. Referido autor, amparado nas lições de James Leslie Brierly, também pontua que os tratados normativos de elevado valor moral e social, como, por exemplo, as Convenções de Genebra sobre direito humanitário aplicável aos conflitos armados, seriam considerados indenunciáveis, porquanto concebidos para estabelecer um estado de coisas permanente. ${ }^{362}$

\footnotetext{
${ }^{361}$ A respeito confira-se op. cit., p. 60.

${ }^{362}$ Op. cit. (Direito dos Tratados...), p. p. 486-487. Adverte JosÉ FrANCISCO REZEK, todavia, que, se na prática internacional esta última categoria de tratados costumam ser raramente objeto de denúncia, tal circunstância não revela se a sua razão abriga-se no entendimento de que seriam eles legalmente imunes à
} 
A Convenção de Viena sobre Direito dos Tratados de 1966 contém regra específica sobre a possibilidade ou não de submissão de um tratado internacional à denúncia, em seu art. 56, nos seguintes moldes:

1. Um tratado que não contenha disposições sobre sua terminação nem preveja a denúncia ou retirada do mesmo não poderá ser objeto de denúncia ou de retirada, a menos:

a) que conste ter sido intenção das partes admitir a possibilidade de denúncia ou de retirada; ou

b) que o direito de denúncia ou de retirada possa inferir-se da natureza do tratado.

De acordo com o dispositivo convencional supracitado, a questão da natureza do diploma será fator importante para a determinação da sua suscetibilidade ou não à denúncia quando inexistir preceitos relativos à sua terminação. Todavia, uma hermenêutica teleológica em torno desse dispositivo permite inferir também que, mesmo na hipótese em que haja uma expressa previsão da faculdade de retirada unilateral de um tratado, tal não se afiguraria como aceitável se a sua natureza assim não permitisse.

No que concerne à disciplina procedimental da denúncia, cumpre destacar que, na maior parte dos casos, o próprio tratado internacional traz explícita as regras para a sua realização válida.

Em geral, há o estabelecimento de lapsos temporais para a acomodação de interesses dos demais co-pactuantes. Assim, é comum a fixação de um pré-aviso ou de um prazo de dilação para o início dos efeitos da retirada. Há igualmente, na prática internacional, tratados que estabelecem prazos de vigência com prorrogação automática, nos quais, após o decurso de um determinado lapso, como, por exemplo, cinco anos, abrese às partes a possibilidade de exercitar a faculdade da denúncia.

A denúncia é expressa por algum meio escrito, normalmente uma notificação, carta ou instrumento, endereçado nos acordos bilaterais ao governo copactuante e, nos multilaterais, ao depositário do tratado internacional. Há situações, porém, que exigem que a notificação da denúncia se dê não apenas em relação aos co- 
participantes, mas também a terceiros, dotados de algum interesse próprio em ter ciência do ato. ${ }^{363}$

Informa JoSÉ FRANCISCO REZEK que a denúncia é um ato retratável, não se concebendo em favor da parte contrária nenhum direito de objeção ao gesto com que o Estado retirante, no decorrer do prazo de acomodação, volta atrás de sua decisão e resolve permanecer vinculado ao tratado. Todavia, caso os efeitos da denúncia já tenham sido consumados, ou seja, se o pacto bilateral já tenha sido extinto ou se o Estado já se pôs fora do domínio jurídico de um tratado multilateral, não há que se cogitar em retratação, mas na celebração de novo acordo ou em nova adesão. ${ }^{364}$

Quanto à regulação do instituto pelo direito brasileiro, é mister salientar que, à exemplo do que ocorre com a questão da incorporação e hierarquia dos tratados, há tradicionalmente uma negligência legislativa no estabelecimento de regras que permitam uma disciplina exaustiva e precisa também em relação a esse tema. Por tal razão, novamente há que se destacar a função da doutrina nacional em tornar explícitas as normas aplicáveis a tal instituto, no âmbito interno.

O cerne das dúvidas repousa em saber qual órgão teria competência para realizar o ato. A questão foi tratada pela primeira vez por Clóvis BEVILAQUA, em 1926, em parecer elaborado ao Itamaraty, quando o Governo Federal pretendeu desligar-se da Liga das Nações. Segundo o aclamado jurisconsulto:

(...) em face da Constituição Federal pode o Poder Executivo, sem ouvir o Congresso Nacional, desligar o país das obrigações de um tratado, que, no seu texto, estabeleça as condições e o modo da denúncia, como é o caso do Pacto da Sociedade das Nações, art. $1^{\circ}$, última parte. Esta proposição parece evidente, por si mesma. Se há no tratado uma cláusula, prevendo e regulando a denúncia, quando o Congresso aprova o tratado, aprova o modo de ser o mesmo denunciado; portanto, pondo em prática essa cláusula, o Poder Executivo apenas exerce um direito que se acha declarado no texto aprovado pelo Congresso. $\mathrm{O}$ ato de denúncia é meramente administrativo. A denúncia do tratado é modo de executá-lo, porquanto numa de suas cláusulas se acha consignado o direito de o dar por extinto. ${ }^{365}$

\footnotetext{
${ }^{363}$ JosÉ FRANCISCO REZEK, op. cit. (Direito dos Tratados...), p. 493.

${ }^{364}$ Op. cit., p. 494.

${ }^{365}$ Pareceres dos Consultores Jurídicos do Ministério das Relações Exteriores - Tomo II - 1913-1934, Rio de Janeiro, MRE, 1962, p.p. 347-354 apud JosÉ FRANCISCO REZEK, op. cit. (Direito dos Tratados...), p. p. 497-499.
} 
E conclui ser o Executivo o órgão com competência exclusiva para exercer a faculdade da retirada unilateral porque a Constituição lhe

(...) confere o direito de representar a Nação em suas relações com as outras. E a ele exerce essa função representativa, pondo-se em comunicação com os Estados estrangeiros; celebrando tratados, ajustes e convenções; nomeando os membros do corpo diplomático e consular; declarando a guerra diretamente, por si, nos casos de invasão ou agressão estrangeira; enfim dirigindo a vida internacional do país, com a colaboração do Congresso, nos casos em que a Constituição a preceitua. Essa colaboração, porém, é excepcional; somente se faz indispensável nos casos prescritos; quando a Constituição guarda silêncio, deve entender-se que a atribuição do Poder Executivo, no que se refere às relações internacionais, é privativa dele. ${ }^{366}$

Solução diversa é apresentada por José FRANCISCO REZEK. De acordo com o ilustre autor se na ordem jurídica nacional há a necessidade da comunhão de vontades entre o governo e o parlamento para obrigar o Estado em uma relação contratual internacional, nenhum tratado poderá continuar em vigor, caso haja, em um determinado momento, uma manifestação de vontade contrária de um desses órgãos. Assim, o ânimo negativo de um dos dois poderes políticos deve implicar a denúncia do instrumento convencional, tendo em vista o desaparecimento de uma das bases imprescindíveis a apoiar o consentimento do Estado em se submeter às suas disposições. Por meio desse fundamento, não haveria, outrossim, lugar à aplicação do princípio do ato contrário, segundo o qual se duas vontades tiverem que se somar para a consecução de um ato, também haverão de se somar para o seu desfazimento. ${ }^{367}$

Finalmente, há a posição de ARNALDO SÜSSEKIND, que a exemplo de Pontes de Miranda, sustenta que o governo do país é quem pratica os atos administrativos que formalizam a ratificação e a denúncia dos tratados. Porém, se o governo não pode aderir a um tratado sem que haja uma prévia autorização do parlamento, a fortiori, também não

\footnotetext{
${ }^{366}$ Clóvis BeVILAQUA, op. cit., p. p. 497-499. Em igual direção posiciona-se HiLdEBRANDO ACCIOLY, para quem "o ato da denúncia, como o da ratificação, é de caráter essencialmente executivo e cabe ao órgão incumbido da apresentação do Estado nas relações internacionais. Além disso, a permissão da denúncia deve achar-se no próprio tratado. Assim, se o ato internacional de que se trate pertence à categoria daqueles que exigem ratificação, precedida da aprovação do Poder Legislativo, sua denúncia unilateral já terá sido autorizada por este, ao aprovar o respectivo texto, no qual, como acabamos de dizer, a denúncia terá sido admitida". In A denúncia dos Tratados, Jornal do Comércio, Rio de Janeiro, 2.09.1956, apud ARNALDo SÜSSEKIND, op. cit. (Direito Internacional...), p. 51.

${ }^{367}$ Op. cit.(Direito dos Tratados...), p. p. 501-504.
} 
poderá denunciá-lo sem o referendo do Poder Legislativo. ${ }^{368}$ Tal conclusão adviria de uma análise teleológica do art. 49, I, da Constituição Federal que determina ao Congresso Nacional resolver definitivamente sobre tratados internacionais. Esse preceptivo, que encerra o controle parlamentar sobre as atividades desenvolvidas pelo Executivo na dinâmica das relações internacionais, não pode ser visto restritivamente - como um comando que determina apenas a necessidade do aval do Congresso para a ratificação -, mas de forma ampla, de modo a albergar também um controle dos órgãos legislativos sobre o exercício, pelo governo brasileiro, da faculdade da denúncia, quando prevista em determinado tratado.

\subsection{Procedimento de Denúncia das Convenções da Organização} Internacional do Trabalho

As convenções internacionais do trabalho contêm, em suas disposições finais, algumas regras que autorizam e disciplinam as suas respectivas denúncias. Na generalidade dos casos, tais regras prescrevem o seguinte:

1. Todo Membro que tiver ratificado a presente convenção poderá denunciá-la no fim de um período de dez anos depois da data da entrada em vigor inicial da convenção, por ato comunicado ao Diretor-Geral da Repartição Internacional do Trabalho e por ele registrado. A denúncia não terá efeito senão um ano depois de ter sido registrada.

2. Todo Membro que, tendo ratificado a presente convenção, dentro do prazo de um ano depois da expiração do período de dez anos mencionado no parágrafo precedente, não fizer uso da faculdade de denúncia prevista no presente artigo, será obrigado por novo período de dez anos e, depois disso, poderá denunciar a presente convenção no fim de cada período de dez anos, nas condições previstas no presente artigo.

A análise de tais disposições permite concluir que a Organização Internacional do Trabalho costuma adotar, em relação a suas convenções, um sistema de prazos de vigência com prorrogação automática, por meio do qual, abre-se aos Estados-

${ }^{368}$ Op. cit. (Direito Internacional...), p. 53. 
Membros a possibilidade de exercitar a faculdade da denúncia nos doze meses subseqüentes ao decurso de dez anos de sua respectiva entrada em vigor.

Há, no entanto, certo dissenso acerca do termo inicial de contagem do referido decênio. Na prática internacional tem prevalecido a idéia de que esse dies a quo corresponde ao início da vigência internacional da convenção, pouco importando o fato de ter sido ela ratificada pelo Estado em um momento bem posterior a essa data. Em sentido contrário, há aqueles, como ARNALDO SÜSSEKIND, que entendem deva ser o começo do aludido prazo correspondente ao momento pelo qual o país assume internacionalmente o compromisso de obrigar-se às disposições da convenção, ou seja, a data em que ratifica o citado instrumento. Para o mencionado autor, uma interpretação sistemática dos dispositivos transcritos fundamentaria essa conclusão. Além disso, a própria lógica jurídica e o bom senso conduziriam a ela, porquanto não seria razoável admitir que um Estado pudesse denunciar um tratado que ratificou poucos dias antes, pelo simples fato de já vigorar no âmbito internacional há dez anos. ${ }^{369}$

A Organização Internacional do Trabalho, como haveria de se supor, não dispõe sobre a competência dos órgãos estatais que seriam responsáveis pela efetivação da denúncia de suas convenções, cabendo ao Direito interno de cada país tal definição. Não obstante tal fato, a Organização aprovou, em 1976, a Convenção Internacional do Trabalho n. 144, relativa a Consultas Tripartites sobre Normas Internacionais do Trabalho, na qual foi estabelecida aos países que a ratificaram a obrigação de submeter as propostas de denúncias das convenções internacionais do trabalho a consultas realizadas por órgãos representativos dos empregadores e dos trabalhadores. ${ }^{370}$

Deve-se ressaltar, ainda, na sistemática da Organização Internacional do Trabalho, a existência da chamada denúncia tácita ou automática das convenções, fruto da ratificação pelo Estado de instrumento de revisão das mesmas. A esse respeito tem sido inserta, desde 1946, quando se aprovou a Convenção n. 80 que reviu diversos diplomas aprovados até então, a seguinte regra na maior parte das convenções internacionais do trabalho: "A ratificação, por um Membro, da nova convenção revisora implicará, ipso jure, a denúncia imediata desta Convenção, sempre que a nova convenção revisora haja entrado em vigor".

\footnotetext{
${ }^{369}$ Op. cit. (Direito Internacional...), p. 239.

370 A Convenção n. 144 foi ratificada pelo Brasil em 27.09.1994 e promulgada pelo Decreto n. 2.518 em 12.03.1998.
} 
Afora essas regras, não há maiores disciplinas estabelecidas no âmbito internacional para a denúncia das convenções internacionais do trabalho, cumprindo destacar apenas que, sob o aspecto formal, esta se aperfeiçoa por meio de um ato de comunicação ao Diretor-Geral do Bureau Internacional do Trabalho, a quem incumbe promover seu registro na Organização.

Quanto ao procedimento definido internamente para a consecução da denúncia das convenções internacionais do trabalho, cabem aqui as mesmas considerações lançadas no tópico anterior quanto à indefinição na ordem jurídica nacional da competência para realização de tal ato, fator que tem suscitado diferentes manifestações doutrinárias sobre o assunto. Na prática, verifica-se a prevalência do entendimento de que seria um ato privativo do Poder Executivo, como se pode denotar pelo procedimento de denúncia adotado em relação à Convenção n. $158^{371}$, muito embora não seja lícito concluir a partir desse fato que esta tese seja a mais adequada aos princípios que orientam a ordem constitucional vigente no Brasil.

\subsection{A Controvérsia Acerca da Impossibilidade de Denúncia das} Convenções Internacionais do Trabalho sobre Direitos Humanos

Dispõe o art. 60, § $4^{\circ}$ da Constituição Federal que:

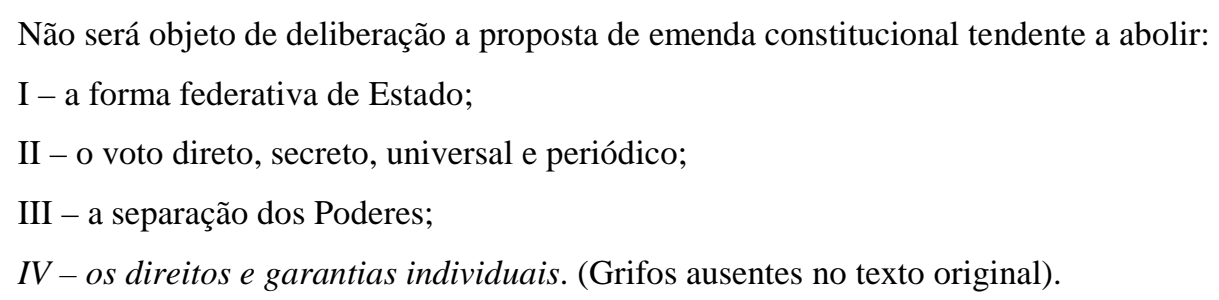

Mencionado comando prevê, de maneira expressa, alguns limites materiais ao poder de reforma da Constituição Federal, comumente denominados de "cláusulas pétreas”, cuja função precípua é a de impedir a destruição dos elementos essenciais da Constituição, encontrando-se nesse sentido, a serviço da preservação da identidade constitucional, formada justamente pelas decisões fundamentais tomadas pelo Constituinte. Tal função se manifesta com maior intensidade no caso dos direitos fundamentais, já que a

${ }^{371}$ A denúncia da Convenção n. 158 ocorreu por simples decreto do Presidente da República em 20.11.1997. 
sua supressão, ainda que tendencial, fatalmente implicaria agressão (em maior ou menor grau) ao princípio da dignidade humana. ${ }^{372}$

Considerando a terminologia adotada pelo legislador constituinte ao fixar como cláusula pétrea "os direitos e garantias individuais", mister se faz a análise da abrangência da referida proteção em matéria de direitos fundamentais, com o intuito de verificar, sobretudo, se os direitos sociais estariam, por ela, abrangidos.

Para INGO WolfGANG SARLET uma interpretação restritiva, que exclua tais direitos fundamentais, deve logo ser afastada, pois esbarram nos seguintes argumentos:

\begin{abstract}
a) a Constituição brasileira não traça qualquer diferença entre o direitos de liberdade (defesa) e os direitos sociais, inclusive no que diz com eventual primazia dos primeiros sobre os segundos; b) os partidários de uma exegese conservadora e restritiva em regra partem da premissa de que todos os direitos sociais podem ser conceituados como direitos a prestações materiais estatais, quando, em verdade, já se demonstrou que boa parte dos direitos sociais são equiparáveis, no que diz com sua função precípua e estrutura jurídica, aos direitos de defesa; c) para além disso, relembramos que uma interpretação que limita o alcance das 'cláusulas pétreas' aos direitos fundamentais elencados no art. $5^{\circ}$ da CF acaba por excluir também os direitos de nacionalidade e os direitos políticos, que igualmente não foram expressamente previstos no art. $60, \S 4^{\circ}$, inc. IV, de nossa lei Fundamental. ${ }^{373}$
\end{abstract}

Acrescente-se a esses argumentos o fato do sistema de direitos humanos ser regido pelo princípio estrutural da complementariedade solidária (confira-se o item 1.5.2, $a$, do capítulo III), pelo qual, consagram-se as noções de indivisibilidade, interdependência e inter-relação dos direitos humanos. Tais conceitos atrelam-se à concepção de que os direitos humanos compõem um núcleo, não podendo ser compartimentalizados ou compreendidos separadamente. Em decorrência, advém, em linhas práticas, a necessidade de se conferir um tratamento global a esses direitos, tendo em vista que a tutela de um deles pode depender da proteção conferida aos demais e vice-versa. Dessa forma, não há como restringir o grau de proteção conferido pelo art. $60, \S 4^{\circ}$, IV, da CF somente aos direitos de liberdade.

As convenções da Organização Internacional do Trabalho sobre direitos humanos, uma vez ratificadas, passam a integrar a ordem jurídica nacional, por força do art. $5^{\circ}, \S \S 1^{\circ}$ e $2^{\circ}$, como direitos fundamentais, ocupando na hierarquia das normas, pelo

\footnotetext{
${ }^{372}$ INGO WOLFGANG SARLET, op. cit., p. p. 434-435.

${ }^{373}$ Op. cit., p. p. 431-432.
} 
menos, o status de preceitos materialmente constitucionais. Como tais, as convenções da Organização Internacional do Trabalho devem gozar do nível de proteção de cláusulas pétreas, não podendo ser suprimidas da ordem jurídica brasileira, por força do disposto no art. $60, \S 4^{\circ}$, IV, da CF.

Esclareça-se, ainda, que por meio de uma interpretação teleológica do preceito mencionado é possível aduzir que é de sua índole o estabelecimento de uma proteção contra a destruição dos elementos essenciais da Constituição, e não apenas uma limitação à proposição de emendas, como se poderia supor de uma simples exegese gramatical do dispositivo in casu. Em outros termos, o alcance da referida garantia de imutabilidade dá-se inclusive em relação ao poder constituinte de reforma, mas não exclusivamente a ele, devendo, quaisquer outros atos que tendam a suprimir os direitos fundamentais serem igualmente rechaçados.

Os argumentos supra apresentados parecem, em princípio, serem suficientes para que se alcance a inevitável conclusão de que a faculdade da denúncia - prevista não apenas nas convenções da Organização Internacional do Trabalho, mas também em vários outros instrumentos internacionais de proteção dos direitos humanos ${ }^{374}$ - não poderia, pelo menos na ordem jurídica nacional, ser exercitada. Todavia, a doutrina nacional sempre se mostrou recalcitrante em admitir tal consequiência. Mesmo dentre aqueles juristas que, desde a promulgação da Constituição Federal de 1988, vêm defendendo com veemência a hierarquia constitucional dos tratados de direitos humanos, é possível encontrar certa resistência ao reconhecimento da impossibilidade de denúncia desses diplomas.

Nesse sentido, FlÁvia PIOVESAN é categórica ao afirmar que:

(...) embora os direitos internacionais sejam alcançados pelo art. $60, \S 4^{\circ}$, e não possam ser eliminados via emenda constitucional, os tratados internacionais de direitos humanos materialmente constitucionais são suscetíveis de denúncia por parte do Estado signatário. Com efeito, os tratados internacionais de direitos humanos estabelecem regras específicas concernentes à possibilidade de denúncia por parte do Estado signatário. Os direitos internacionais poderão ser subtraídos pelo mesmo Estado que os incorporou, em face das peculiaridades do regime de direito internacional público. Vale dizer, cabe ao Estado-parte tanto o ato de ratificação do tratado como o de denúncia, ou seja, o ato de retirada do

${ }^{374}$ Confira-se Flávia PIOVESAN, op. cit. (Direitos Humanos e o Direito Constitucional Internacional...), p. 75. 
mesmo tratado. Os direitos internacionais apresentam, assim, natureza constitucional diferenciada". ${ }^{375}$ (Grifos ausentes no original).

Com esteio no mesmo raciocínio, VALÉRIO DE OliveIRA MAZZUOLI explica que os instrumentos internacionais de direitos humanos que apenas gozam do status de normas materialmente constitucionais poderiam ser denunciados. De tal ato, porém, somente adviria a desobrigação do Estado no âmbito internacional quanto ao cumprimento das disposições do tratado, ou seja, a terminação de sua responsabilidade na órbita exterior. Remanesceriam, porém, como decorrência do estatuído no art. $60, \S 4^{\circ}$, IV, da Constituição Federal, vigentes os preceitos do tratado denunciado no âmbito interno. Nas palavras do citado autor,

(...) sob esse ponto de vista, a denúncia dos tratados de direitos humanos é tecnicamente possível (sem a possibilidade de se responsabilizar o Presidente da República nesse caso), mas totalmente ineficaz sob o aspecto prático, uma vez que os efeitos do tratado denunciado continuam a operar dentro do nosso ordenamento jurídico, pelo fato de eles serem cláusulas pétreas do texto constitucional. ${ }^{376}$

Para os referidos autores, o novel $\S 3^{\circ}$ do art. $5^{\circ}$, da Constituição Federal, trouxe, contudo, uma mudança de panorama no tocante à matéria. Para eles, como já visto anteriormente, os tratados internacionais de direitos humanos aprovados em ambas as Casas Legislativas, pelo quórum qualificado de três quintos, em dois turnos de votação, passam a gozar, além do status de norma materialmente constitucional, também da natureza de norma formalmente constitucional. Como conseqüência da integração desses diplomas ao próprio texto constitucional, resulta um maior grau de proteção, o que permitiria sustentar ter o Estado renunciado à sua prerrogativa de, em um determinado momento, denunciá-los. ${ }^{377}$

375 Op. cit. (Direitos Humanos e o Direito Constitucional Internacional...), p. p. 75-76.

${ }^{376}$ Op. cit. (Curso...), p. p. 507-509.

377 A esse respeito, FLÁVIA PIOVESAN assevera: "Diversamente dos tratados materialmente constitucionais, os tratados material e formalmente constitucionais não podem ser objeto de denúncia. Isto porque os direitos neles enunciados receberam assento no Texto Constitucional, não apenas pela matéria que veiculam, mas pelo grau de legitimidade popular contemplado pelo especial e dificultoso processo de sua aprovação, concernente à maioria de três quintos dos votos dos membros, em cada Casa do Congresso Nacional, em dois turnos de votação. Ora, se tais direitos internacionais passaram a compor o quadro constitucional, não só no campo material, mas também no formal, não há como admitir que um ato isolado e solitário do Poder 
Com todo respeito aos insignes juristas, é mister destacar alguma críticas que podem ser apostas às teses por eles defendidas. Em primeiro lugar, parece ser equivocada a interpretação que subjaz de suas posições relativamente ao dispositivo constitucional consagrador das denominadas cláusulas pétreas. Como já ressaltado acima, ao criar o art. $60, \S 4^{\circ}$, a intenção do legislador constituinte originário foi a de assegurar um núcleo intangível à Carta Política e não a de estabelecer exclusivamente limitações ao poder de elaborar emendas. A alusão expressa à vedação de propostas destes específicos instrumentos legislativos deve ser compreendida apenas pelo fato de serem eles o mecanismo mais dificultoso, vislumbrado pelo legislador, para realizar a modificação do texto constitucional e, portanto, abolir potencialmente direitos fundamentais, o que não significa dizer que outros instrumentos, menos complexos estariam permitidos. De fato, seria um verdadeiro paradoxo vedar a supressão de direitos fundamentais via emenda à Constituição e admitir que a denúncia de um tratado - cuja prática tem revelado, ainda que inadequadamente, ser um simples ato do Poder Executivo, segundo sua melhor conveniência -, possa suprimi-los.

Em segundo lugar, do ponto de vista lógico, não avulta como sendo a melhor das soluções a construção explicitada por Valério de Oliveira Mazzuoli, segundo a qual haveria uma possibilidade técnica para a denúncia de tratados apenas materialmente constitucionais (fator esse que liberaria o Estado de responsabilidades no plano internacional), mas uma total ineficácia, na órbita interna, desse ato em razão da permanência em vigor dos preceitos do tratado denunciado, inclusive para a regulação de relações jurídicas futuras. Como o próprio autor sustenta que tais tratados não integram a

Executivo subtraia tais direitos do patrimônio popular - ainda que a possibilidade de denúncia esteja prevista nos próprios tratados de direitos humanos ratificados, como já apontado. É como se o Estado houvesse renunciado a essa prerrogativa de denúncia, em virtude da 'constitucionalização formal' do tratado no âmbito jurídico interno". In op. cit., p. 77. VALÉRIO DE OLIVEIRA MAZZUOLI sustenta a mesma posição ao afirmar que: "Mas caso o tratado de direitos humanos tenha sido aprovado nos termos do $\S 3^{\circ}$ do art. $5^{\circ}$, o Brasil não pode mais desengajar-se do tratado quer no plano internacional, quer no plano interno (o que não ocorre quando o tratado detém apenas status de norma constitucional), podendo o Presidente da República ser responsabilizado caso o denuncie (devendo tal denúncia ser declarada ineficaz). In op. cit.(Curso...), p. p. 508-509. Em igual direção parece caminhar o entendimento de INGO WOLFGANG SARLET, que ao fazer uma exegese sistemático-teleológica dos $\S \S 2^{\circ}$ e $3^{\circ}$, do art. $5^{\circ}$, destaca que a "inovação trazida pela Reforma do Judiciário pode ser interpretada simplesmente como assegurando hierarquia pelo menos materialmente constitucional jusfundamental a todos os direitos fundamentais (já que, uma vez incorporados, os direitos humanos passam também - e acima de tudo - a serem todos fundamentais) e também formalmente constitucional aos tratados incorporados pelo rito de emenda constitucional, que, de resto, receberiam (de vez que alguma diferenciação nos parece inevitável) um tratamento distinto (no sentido de mais reforçado) quanto ao fato de se integrarem à Constituição textual e enrobustecerem a tese da impossibilidade de uma posterior denúncia do tratado e da responsabilização até mesmo interna se este vier a ocorrer". In op. cit., p. 160. 
constituição formal do país, ou seja, não fazem efetivamente parte do Texto Constitucional, questiona-se a que título seriam válidas na ordem jurídica interna as disposições de um tratado que, em um dado momento, deixa de se integrar a esse sistema jurídico?

Finalmente, cumpre afastar a premissa aventada por Flávia Piovesan de que, em razão das peculiaridades do regime de Direito Internacional Público, seria possível admitir a denúncia de tratados de direitos humanos. Como já estudado no tópico 4.1 deste capítulo, a doutrina internacionalista expõe que a possibilidade de denúncia dos tratados é condicionada tanto pela sua expressa admissão, como pela sua natureza. Nesse diapasão, existem tratados que não podem ser submetidos ao procedimento de denúncia, como por exemplo, os tratados de fronteiras ou os tratados normativos de elevado valor moral e social. Os instrumentos internacionais de direitos humanos inserem-se justamente nessa última categoria, sendo princípio latente do sistema de proteção desses direitos a garantia de sua irrevogabilidade.

O princípio da irrevogabilidade ou da irreversibilidade dos direitos fundamentais ou, ainda, da vedação ao retrocesso social (vide subitem 1.5.2., b, do capítulo III desta dissertação) traduz que uma vez declarado oficialmente um direito humano, ele se incorpora de forma definitiva à consciência ética universal, tornando-se insuprimível por via de novas regras constitucionais ou atos internacionais.

A esse respeito, FÁBIO KONDER COMPARATO, com extrema propriedade, salienta que uma das conseqüências do princípio da irreversibilidade

(...) é a proibição de pôr fim, voluntariamente, à vigência de tratados internacionais de direitos humanos. Em particular, o Estado-Parte, num tratado que tenha como objeto, total ou parcial, a declaração de direitos humanos ou a regulação de garantias fundamentais, não pode denunciá-lo, nem mesmo com a aprovação do ato de denúncia pelo órgão ratificador. A exigência de aprovação parlamentar prévia da denúncia de um tratado internacional a ser feita pelo Chefe de Estado, embora não exigida pela generalidade das Constituições vigentes, nada mais é, afinal, do que a aplicação do princípio da paridade de forma dos atos de constituição e extinção de uma relação jurídica (convencional ou não). Ora, o poder de denunciar uma convenção internacional só faz sentido quando esta cuida de direitos disponíveis. Em matéria de tratados internacionais de direitos humanos, não há nenhuma 
possibilidade de denúncia, ou de cessação convencional da vigência, porque se está diante de direitos indisponíveis e, correlatamente, de deveres insuprimíveis. ${ }^{378}$

Como decorrência do princípio da irreversibilidade, não se pode atribuir validade às cláusulas contidas em diplomas internacionais de direitos humanos que prevejam expressamente a sua denúncia, como sói ocorrer com a maioria das convenções internacionais do trabalho e outros tantos instrumentos convencionais. Nesse tocante, lapidar é a lição de LEANDRO CALETTI, para quem o princípio da irrevogabilidade,

(...) na medida em que é elevado à categoria de direito internacional imperativo (jus cogens), inviabiliza até mesmo a expressa previsão de denúncia, contida em tratado de direitos humanos, que deve, assim, ser tida por inválida, já que, como assinala o artigo 53 da Convenção sobre Direito dos Tratados, 'é nulo um tratado que, na época de sua conclusão, esteja em conflito com uma norma imperativa de direito internacional geral'. Este é definido pela Convenção como 'uma norma aceita e reconhecida pela comunidade internacional dos Estados em sua totalidade, como uma norma da qual não se admite derrogação e que só pode ser modificada uma nova norma de direito internacional', também cogente. Assim, seria irrelevante a previsão de denúncia contida em vários tratados internacionais de direitos humanos. ${ }^{379}$

Disso resulta que a proibição da denúncia das convenções internacionais do trabalho e de outros tratados internacionais que trazem em seu conteúdo normas de direitos humanos, não foi uma novidade introduzida pela Emenda Constitucional n. 45/04, advindo, antes, do próprio regime constitucional anterior à referida reforma. Em termos distintos, o que se quer afirmar é que a constitucionalização formal dos tratados de direitos humanos, permitida pelo $\S 3^{\circ}$ do art. $5^{\circ}$, deve ser vista somente como mais um elemento a enrobustecer a tese da impossibilidade de denúncia desses instrumentos, mas não como um fator determinante para tanto. O simples status de norma materialmente constitucional e o princípio estrutural do sistema de direitos humanos da irreversibilidade já são suficientes, per se, para determinar a proibição da denúncia dos tratados e convenções internacionais do trabalho sobre direitos humanos.

\footnotetext{
${ }^{378}$ Op. cit., p.p. 66-67.

${ }^{379}$ LEANDRo CALETTI, A Incorporação dos Tratados Internacionais de Direitos Humanos no Cenário da Emenda à Constituição n. 45/2004 - Notas acerca da Compulsoriedade do Novo Regime e da Denúncia dos Tratados, disponível em http://jus2.uol.com.br/doutrina/texto.asp?id=9754\&p=2.
} 


\section{CONSIDERAÇÕES FINAIS}

Objetivou-se com a presente dissertação de mestrado realizar uma análise das convenções da OIT, assim como, da integração de tais instrumentos normativos à ordem jurídica nacional com enfoque especial sobre: as regras de Direito Internacional e de Direito interno aplicáveis ao processo integrativo desses diplomas; o problema da hierarquia das convenções incorporadas no sistema jurídico brasileiro; e, finalmente, as questões relativas à denúncia das referidas normas convencionais.

Para tanto, deu-se ênfase, inicialmente, a um estudo sobre as características essenciais da OIT, como forma de entender seus propósitos e estrutura, e, assim, permitir o desvelamento dos particularismos relacionados às suas convenções internacionais.

Demonstrou-se que a idéia de estabelecer uma regulamentação das relações de trabalho no plano internacional remonta à primeira metade do século XIX, quando, sobretudo, na Europa passou-se a conhecer os efeitos negativos das profundas transformações sociais desencadeadas a partir da Revolução Industrial e da Revolução Francesa. O quadro de profunda penúria experimentado pelo operariado, nas primeiras décadas do capitalismo industrial, fez com que este se organizasse como classe e desencadeasse um processo reivindicatório pela melhoria de sua condição social, o que disseminou em vários países o sentimento acerca da necessidade da intervenção estatal nas relações laborais, com o escopo de se criar uma legislação protetiva.

Por sua vez, a preocupação com a concorrência econômica internacional, foi determinante para a propagação da idéia de que seriam necessários esforços uniformes e simultâneos por parte dos principais países industrializados para uma proteção eficaz dos direitos dos trabalhadores. Foi assim que, ainda no final do Século XIX, surgiram as primeiras iniciativas visando à criação de uma legislação internacional do trabalho e que se fortaleceu o projeto de se formar um organismo internacional responsável pela sua consecução.

A intensa agitação sindical ocorrida no início do século XX e a participação de um grande contingente de trabalhadores na Primeira Guerra Mundial constituíram, finalmente, os elementos restantes para que a opinião pública mundial atingisse um consenso em torno da imperiosa necessidade de se garantir, no Tratado que pôs fim à Guerra, um mecanismo de tutela das relações de trabalho. Criou-se, desse modo, com o Tratado de Versalhes de 1919, a OIT, cujos objetivos primordiais eram: assegurar bases 
sólidas para a paz universal; eliminar as condições de trabalho que gerassem injustiça, miséria e privações; permitir que a concorrência internacional não se constituísse um entrave aos países na proteção das relações laborais.

A OIT nasceu juridicamente atrelada à Liga das Nações, mas, na prática, sua atuação sempre foi marcada por relativa autonomia. Por conta disso, a eclosão da Segunda Guerra Mundial e o inexorável reconhecimento do fracasso da Liga das Nações não determinou o fim da OIT, que passou, a partir de 1946 a vincular-se à ONU como entidade especializada, porém, dotada de personalidade jurídica internacional própria, ostentado, sob todos os aspectos, a natureza de uma verdadeira organização internacional.

Houve, entretanto, a adaptação de seus objetivos ao novo quadro político mundial, que, com a incorporação da Declaração da Filadélfia de 1944 à Constituição da OIT em 1946, passaram a ser mais amplos, abrangendo também ações de cooperação técnica destinadas a promover o bem-estar material e espiritual da humanidade como um todo.

No tocante à sua estrutura, a OIT inovou o panorama do Direito Internacional Público, em razão da adoção do princípio do tripartismo na composição de seus principais órgãos. A fórmula, que congrega representantes governamentais ao lado de membros da sociedade civil, que, por sua vez, representam cada um dos pólos das relações laborais: empregadores e trabalhadores, confere um maior grau de legitimidade à produção normativa dessa Instituição.

Já adentrando, propriamente, sobre uma análise das convenções internacionais do trabalho, esta investigação revelou que tais diplomas, principais instrumentos normativos da OIT e do próprio Direito Internacional do Trabalho, podem ser enquadrados no conceito amplo de tratados internacionais. Nesse sentido, ostentam a natureza de instrumentos multilaterais, abertos à ratificação pelos Estados-Membros da OIT e destinados a regular, de maneira relativamente homogênea, as relações de trabalho existentes no interior de cada país, estabelecendo um patamar mínimo de proteção aos trabalhadores.

A nota distintiva das convenções da OIT em relação aos demais tratados reside justamente no fato de que são elaboradas no âmbito de uma Conferência Internacional que possui delegados não-governamentais, fator este que as coloca como figuras ímpares no Direito Internacional. 
A doutrina e a própria OIT apresentam diversas formas de classificação das convenções internacionais do trabalho. Porém, nenhuma delas mostra-se tão útil à análise das questões relacionadas à recepção dos citados diplomas legais pela ordem jurídica nacional, quanto uma proposta classificatória que permita identificar, com um mínimo de objetividade, quais convenções possuem um conteúdo de direitos humanos e quais não possuem. Tal se justifica pela diversidade de regimes aplicáveis aos tratados de direitos humanos no que tange à mencionada problemática $\left(\operatorname{art} .5^{\circ}, \S \S 2^{\circ}\right.$ e $3^{\circ}$, da Constituição Federal).

Por essa razão, foram examinados alguns dos principais assuntos do universo temático dos direitos humanos, sendo proposto um critério para a identificação das convenções da OIT com tal conteúdo.

Referida pesquisa demonstrou, dentre outras coisas, que modernamente prevalece a concepção doutrinal que procura enxergar os direitos humanos como direitos históricos, resultantes de um longo processo cultural de lutas pela afirmação da dignidade humana.

Nesse diapasão, é inegável que o Direito do Trabalho constitua-se uma das mais perfeitas traduções da lógica de construção dos direitos humanos. De fato, a miséria, a dor e o sofrimento experimentados pelo operariado nos primórdios do capitalismo industrial, comparáveis moralmente, aos efeitos deletérios de uma guerra, fez com que ele se organizasse e, como uma classe social, desencadeasse um amplo processo de lutas pela melhoria de suas condições de vida. As vitórias do movimento operário foram, paulatinamente, determinando a afirmação de novos direitos, caracterizados pela sua expressão econômica e social. No início do século $\mathrm{XX}$, tais direitos já haviam se disseminado como valores supremos de garantia da dignidade humana, passando, após a criação da OIT em 1919, a integrar a consciência ética universal e as bases axiológicas do sistema jurídico de diversos países.

Não se torna difícil sustentar, assim, que a essência de todo o Direito do Trabalho e, conseqüentemente, o conteúdo das principais normas jurídicas que o compõem - dentre as quais, a maior parte das convenções da OIT - sejam os direitos humanos.

No entanto, reconhece-se que apesar desse largo esteio valorativo, nem toda a ação normativa da referida Organização redunde necessariamente em normas de direitos humanos. 
A própria OIT, admitindo tal fato, procurou delimitar as convenções que apresentariam o caráter de normas de direitos humanos, por meio da elaboração da Declaração de Princípios e Direitos Fundamentais no Trabalho de 1998. A despeito da validade da iniciativa sob o ponto de vista político, a proposta da Organização descortinouse extremamente restritiva e frágil sob a ótica jurídica.

Nesse contexto, ofereceu-se, nesta dissertação, uma alternativa, construindose um critério de identificação das convenções da OIT sobre direitos humanos, que procurou adequar o princípio da equivalência - empregado por diversos Estados, como mecanismo próprio de reconhecimento de direitos fundamentais não expressos em suas Constituições - a uma perspectiva universalista de abordagem dos direitos humanos.

De acordo com esse critério, as convenções da OIT que apresentarem a mesma substância e importância de preceitos consagrados pela Declaração Universal de Direitos do Homem de 1948 e/ou pelos Pactos da ONU de 1966, a eles, materialmente, se equiparam, sendo imperiosa a admissão de que se cuidam igualmente de tratados internacionais de direitos humanos. Como tais, a eles se aplicam todos os princípios estruturais do sistema dos direitos humanos, tais como, a complementariedade solidária, a eficácia imediata e a irreversibilidade.

Com sustentáculo em todo esse arcabouço teórico, esquadrinharam-se os temas relativos à integração das convenções internacionais do trabalho ao ordenamento jurídico pátrio.

Inicialmente, evidenciou-se que as teorias construídas em torno da questão das relações entre Direito Internacional e Direito interno, ou seja, o monismo e o dualismo não se antagonizam, atualmente, com a mesma intensidade em que foram elaboradas (início do século XX). A evolução de ambas as concepções para vertentes mais moderadas tornou as distinções existentes entre elas praticamente irrelevantes, sendo possível concluir que a escolha por uma ou outra teoria baseia-se mais em fatores ideológicos, do que propriamente científicos.

Quanto ao procedimento de recepção das convenções internacionais do trabalho pelo direito nacional, explicou-se que o ato de adesão a um tratado internacional em geral depende, segundo as regras do Direito Constitucional brasileiro, da conjugação de vontades entre o Poder Executivo e o Poder Legislativo. Desse modo, a ratificação de normas internacionais, em geral, precede de uma prévia aprovação de seu texto pelo Congresso Nacional, materializada por meio de um decreto legislativo que autoriza o 
Presidente da República a ratificá-las. O chefe do Executivo, entretanto, possui o poder discricionário para realizar ou não a ratificação, ainda que haja a aprovação legislativa. Após esse trâmite, a praxe nacional tem exigido, ainda, a edição de um decreto executivo para sua entrada em vigor no país. Tal procedimento aplica-se integralmente às convenções internacionais que não trazem em seu conteúdo normas de direitos humanos. Todavia, em se tratando de convenções da OIT qualificadas como tratados de direitos humanos há algumas peculiaridades.

Em primeiro lugar, com base no princípio da aplicação imediata, a moderna doutrina constitucional brasileira, tem sustentado, de maneira acertada, ser dispensável a edição de decreto executivo para sua vigência interna.

Em segundo lugar, é defensável que, a partir da Emenda Constitucional n. 45/04, o procedimento para a integração desses instrumentos tenha sofrido, no Direito pátrio, significativa alteração. Nesse diapasão, a doutrina constitucionalista tem-se posicionado acerca de dois entendimentos distintos.

Para uma parte dela, é razoável supor que, desde a introdução do $\S 3^{\circ}$ ao art. $5^{\circ}$ da Constituição Federal, todas as convenções internacionais do trabalho cujo conteúdo seja de direitos humanos deverão ser obrigatoriamente aprovadas pelo Congresso Nacional, por um sistema análogo ao de votação das emendas constitucionais, para que só então possam ser ratificadas pelo Presidente da República.

Já para a outra corrente, a partir da alteração introduzida pelo poder constituinte reformador, passou-se a adotar um procedimento dúplice, pelo qual subsistiriam as mesmas etapas contempladas aos tratados em geral até o ato de ratificação, mas, posteriormente a ele, seria permitida a submissão, a qualquer tempo, das convenções a uma nova aprovação legislativa, sob a forma análoga ao da elaboração de emendas constitucionais, com o único propósito de conferir-lhes o mesmo status hierárquico desses instrumentos.

No tocante à problemática da hierarquia das convenções, a despeito da enorme cizânia doutrinária e jurisprudencial acerca do tema, sobretudo, no que condiz com o status dos instrumentos internacionais de direitos humanos e da necessidade de uma maior maturação do assunto na Ciência Jurídica, em razão das inovações introduzidas pela Emenda Constitucional n. 45/04, foi possível deduzir algumas conclusões.

De início, acerca das convenções internacionais do trabalho sobre direitos humanos integradas ao sistema jurídico brasileiro, é plenamente sustentável a posição de 
que elas gozam, pelo menos, da estatura de normas materialmente constitucionais. Tal convicção alicerça-se, na cláusula de abertura da Constituição Federal (art. $5^{\circ}, \S 2^{\circ}$ ) a outros direitos fundamentais não constantes expressamente em seu catálogo, bem como, na força expansiva do princípio axiológico da dignidade humana.

Em relação às convenções internacionais do trabalho ratificadas que não se qualificam como tratados de direitos humanos, deve-se reconhecer que não possuem a mesma envergadura das normas constitucionais, podendo-se sustentar, quando muito, um caráter infraconstitucional, mas supralegal desses diplomas, tendo por base o princípio da boa-fé internacional e o disposto no art. 27 da Convenção de Viena sobre Direito dos Tratados.

Finalmente, quanto ao aspecto da denúncia das convenções internacionais do trabalho, ressaltou-se, nesta dissertação, que a própria OIT vislumbra, de maneira indistinta, a possibilidade de sua realização, disciplinando-a parcialmente, por meio da inclusão de cláusulas sobre o assunto nas disposições finais da maioria desses diplomas.

No que se refere ao procedimento definido internamente para a consecução da denúncia das convenções internacionais do trabalho, verifica-se uma grande indefinição na ordem jurídica nacional da competência para realização de tal ato, fator que tem suscitado diferentes manifestações doutrinárias sobre o assunto. Na prática, verifica-se, porém, a prevalência do entendimento de que seria um ato privativo do Poder Executivo.

Levando-se em conta, todavia, toda a construção teórica desenvolvida ao longo deste trabalho, chegou-se à conclusão de que, relativamente às convenções da OIT sobre direitos humanos, não se afiguraria como possível o exercício da denúncia. Isso porque tais normas internacionais, uma vez ratificadas, passam a integrar a ordem jurídica nacional, por força do art. $5^{\circ}, \S \S 1^{\circ}$ e $2^{\circ}$, como direitos fundamentais, ocupando na hierarquia das normas, pelo menos, o status de preceitos materialmente constitucionais. Como tais, as convenções internacionais do trabalho devem gozar do nível de proteção de cláusulas pétreas, não podendo ser suprimidas da ordem jurídica brasileira, por força do disposto no art. 60, § $4^{\circ}$, IV, da Constituição Federal. Além disso, em razão da aplicação do princípio da irreversibilidade, informador do sistema dos direitos humanos, não se permite que um direito declarado oficialmente seja suprimido por via de novas regras constitucionais ou atos internacionais. Como consequiência, inviabiliza-se a adoção, em textos internacionais de direitos humanos, de cláusulas contemplando expressamente sua 
denúncia, devendo aquelas contidas nas convenções da OIT, classificadas como tal, serem tidas por inválidas. 


\section{BIBLIOGRAFIA}

AcCiOly, Hildebrando. Tratado de Direito Internacional Público. Vol. I. $2^{\text {a }}$ ed. Rio de Janeiro: Ministério das Relações Exteriores, 1956.

Annoni, Danielle (org.). Os Novos Conceitos do Novo Direito Internacional-Cidadania, Democracia e Direitos Humanos. Rio de Janeiro: América Jurídica, 2002.

BAHIA, Saulo José Casali. Tratados Internacionais no Direito Brasileiro. Rio de Janeiro: Forense, 2000.

BARzotTo, Luciane Cardoso. Direitos Humanos e Trabalhadores - Atividade Normativa da Organização Internacional do Trabalho e os Limites do Direito Internacional do Trabalho. Porto Alegre: Livraria do Advogado, 2007.

BAsso, Maristela. A Convenção n. 158 da Organização Internacional do Trabalho e o Direito Constitucional Brasileiro, in Trabalho \& Doutrina, 11 (dezembro de 1996), p. p. 30-39.

Bastos, Celso Ribeiro; Martins, Ives gandra. Comentários à Constituição de 1988. Vol. II. São Paulo: Saraiva, 1989.

Beltran, Ari Possidônio. Direito do Trabalho e Direitos Fundamentais. São Paulo: LTr, 2002.

BobBIO, Norberto. A Era dos Direitos. Trad. port. de Carlos Nelson Coutinho. São Paulo: Campus, 1992.

Cachapuz de Medeiros, Antônio Paulo. O Poder de Celebrar Tratados - Competência dos Poderes Constituídos para a Celebração de Tratados à Luz do Direito Internacional, do Direito Comparado e do Direito Constitucional Brasileiro. Porto Alegre: Sérgio Antônio Fabris Editor, 1995. 
CAletTI, Leandro. A Incorporação dos Tratados Internacionais de Direitos Humanos no Cenário da Emenda à Constituição n. 45/2004 - Notas acerca da Compulsoriedade do Novo Regime e da Denúncia dos Tratados. Disponível em http://jus2.uol.com.br/doutrina/ texto.asp?id=9754\&p=2. Acesso em 14/10/2008.

Cançado Trindade, Antônio Augusto. A Proteção Internacional dos Direitos Humanos e o Brasil (1948-1997) - As Primeiras Cinco Década. Brasília: UNB, 1998.

Cançado Trindade, Antônio Augusto. Direitos Humanos e Meio Ambiente - Paralelo dos Sistemas de Proteção Internacional. Porto Alegre: Sergio Antonio Fabris, 1993.

Cançado Trindade, Antônio Augusto. Direito Internacional e Direito Interno - Sua Interpretação na Proteção de Direitos Humanos, in Instrumentos Internacionais de Proteção dos Direitos Humanos. 2ª ed. San Jose - Costa Rica/Brasília: IIDH, 1996.

Cançado Trindade, Antônio Augusto. Tratado de Direito Internacional dos Direitos Humanos. Vol. I. Porto Alegre: Sérgio Antônio Fabris Editor, 1997.

Canotilho, José Joaquim Gomes. Direito Constitucional e Teoria da Constituição. $4^{\mathrm{a}}$ ed. Coimbra: Almedina, 2000.

Casella, Paulo Borba. A Convenção n. 158 da OIT - As Relações entre Direito Interno e Direito Internacional, in LTr, 60 (1996), p. p. 900-909.

CASSESE, Antonio. International Law. $2^{\mathrm{a}}$ ed. Oxford: Oxford University Press, 2005.

Comparato, Fábio Konder. A Afirmação Histórica dos Direitos Humanos. $3^{\mathrm{a}}$ ed. São Paulo: Saraiva, 2004.

Comparato, Fábio Konder. Ética - Direito, Moral e Religião no Mundo Moderno. São Paulo: Companhia das Letras, 2006. 
Comparato, Fábio Konder. Fundamento dos Direitos Humanos. Instituto de Estudos Avançados da Universidade de São Paulo. Disponível em www.iea.usp.br/artigos. Acesso em $14 / 10 / 2008$.

CRetella Júnior, José. Comentários à Constituição de 1988. $2^{\mathrm{a}}$ ed. Rio de Janeiro: Forense, 1992.

Dallari, Pedro B. de Abreu. Constituição e Tratados Internacionais. São Paulo: Saraiva, 2003.

Dinh, Nguyen Quoc; DAILlier, Patrick; Pellet, Alain. Droit International Public. Trad. port. de V. M. Coelho. Direito Internacional Público. $2^{\mathrm{a}}$ ed. Lisboa: Fundação Calouste Gulbenkian, 2003.

EMERIQUE, Lilian Balmant; GUERRA, Sidney. A Incorporação dos Tratados Internacionais de Direitos Humanos na Ordem Jurídica Brasileira, in Revista Jurídica. Vol. 10. N. 90. Edição Especial. Brasília: Centro de Estudos da Subchefia para Assuntos Jurídicos da Casa Civil da Presidência da República, Abril/Maio de 2008.

Ferreira Filho, Manoel Gonçalves. Comentários à Constituição Brasileira de 1988. Vol. 1. $2^{a}$ ed. São Paulo: Saraiva, 1997.

FerreIRA FILHO, Manoel Gonçalves. Direito Humanos Fundamentais. São Paulo: Saraiva, 1995.

Fraga, Mirtô. O Conflito entre Tratado Internacional e Norma de Direito Interno Estudo Analítico da Situação do Tratado na Ordem Jurídica Brasileira. Rio de Janeiro: Forense, 1998.

GALINDO, George Rodrigo Bandeira. A Reforma do Judiciário como Retrocesso para a Proteção Internacional dos Direitos Humanos: um Estudo sobre o Novo $\S 3^{\circ}$ do Artigo $5^{\circ}$ da Constituição Federal, in Cena Internacional, 1 (2005). 
Garcia, Maria. Os Tratados Internacionais e a Constituição - A Convenção n. 158 da OIT, in Trabalho \& Doutrina, 11 (dezembro de 1996), p. p. 23-29.

GHIONE, Hugo Barreto. Investigación sobre la Aplicación de los Principios y Derechos Fundamentales en el Trabajo en Uruguay. Lima: OIT, 2006.

Giglio, Wagner D. O.I.T. e Convenções Internacionais do Trabalho Ratificadas pelo Brasil. São Paulo: Sugestões Literárias, 1973.

GOMES, Luiz Flávio. A Questão da Obrigatoriedade dos Tratados e Convenções no Brasil - Particular Enfoque da Convenção Americana sobre Direitos Humanos, in RT, 710 (1994).

Hobsbawm, Eric j. A Era das Revoluções - Europa 1789-1848. Trad. Port. de Maria Tereza Lopes Teixeira e Marcos Penchel. 21ª ed. São Paulo: Paz e Terra, 2007.

HuseK, Carlos Roberto. Curso de Direito Internacional Público. $3^{\text {a }}$ ed. São Paulo: LTr, 2000.

IGLÉSIAS, Francisco. História Geral e do Brasil. São Paulo: Ática, 1989.

Kelsen, Hans. Teoria Pura do Direito. Trad. Port. de João Baptista Machado. São Paulo: Martins Fontes, 1996.

Lage, Émerson José Alves; LoPes, Mônica Sette. O Direito do Trabalho e o Direito Internacional - Questões Relevantes. São Paulo: LTr, 2005.

Magano, Octavio Bueno. Convenção n. 158 da OIT, in LTr, 60 (1996), p. p. 748-750.

Mazzuoli, Valério de Oliveira. A Influência dos Tratados de Direitos Humanos no Direito Interno. Disponível no site http://jus2.uol.com.br/doutrina/ texto.asp?id=1608. Acesso em $14 / 10 / 2008$. 
Mazzuoli, Valério de Oliveira. Curso de Direito Internacional Público. São Paulo: RT, 2006.

MaZzuoli, Valério de Oliveira. Direito Internacional - Tratados e Direitos Humanos Fundamentais na Ordem Jurídica Brasileira. Rio de Janeiro: América Jurídica, 2001.

MAZzUOLI, Valério de Oliveira. Direitos Humanos e Relações Internacionais. Campinas: Agá Júris, 2000.

Mello, Celso D. de Albuquerque. Curso de Direito Internacional Público. $1^{\circ}$ Vol. $4^{\mathrm{a}}$ ed. Rio de Janeiro: Freitas Bastos, 1974.

Mello, Celso D. de Albuquerque; LoBo, Ricardo (diretores). Arquivos de Direitos Humanos. vol. 1. Rio de Janeiro: Renovar, 1999.

Moraes, Alexandre. Direitos Humanos Fundamentais - Teoria Geral, Comentários aos arts. $1^{o}$ a $5^{o}$ da Constituição da República Federativa do Brasil, Doutrina e Jurisprudência. $3^{\text {a }}$ ed. São Paulo: Atlas, 2000.

NAscimento, Amauri Mascaro. Iniciação ao Direito do Trabalho. $28^{a}$ ed. São Paulo: LTr, 2002.

PereZ LuÑo, Antonio Enrique. Los Derechos Fundamentales. $7^{\text {a }}$ ed. Madrid: Tecnos, 1998.

Pinto e Silva, Otávio. A Função do Direito do Trabalho no Mundo Atual, in Correia, Marcus Orione Gonçalves (org.). Curso de Direito do Trabalho - Teoria Geral do Direito do Trabalho. Vol. I. São Paulo: LTr, 2007.

Piovesan, Flávia. Direitos Humanos e o Direito Constitucional Internacional. $7^{\mathrm{a}}$ ed. São Paulo: Saraiva, 2007. 
Piovesan, Flávia. Direitos Humanos e Relações Internacionais: Desafios e Perspectivas Contemporâneas in CORRÊA, Lélio Bentes; VIDOTTI, Tárcio José (coordenadores). Trabalho Infantil e Direitos Humanos - Homenagem a Oris de Oliveira. São Paulo: LTr, 2005.

Piovesan, Flávia. Direitos Sexuais e Reprodutivos - Aborto Inseguro como Violação aos Direitos Humanos, in SARMEnTo, Daniel; PIOVESAn, Flávia (coord.). Nos Limites da Vida - Aborto, Clonagem Humana e Eutanásia sob a Perspectiva dos Direitos Humanos. Rio de Janeiro: Lumen Iuris, 2007.

PiOvesan, Flávia. Temas de Direitos Humanos. São Paulo: Max Limonad, 1998.

Plá Rodrigues, Américo. Los Convenios Internacionales del Trabajo. Montevidéu: Facultad de Derecho y Ciencias Sociales de la Universidad de la Republica, 1965.

Potobsky, Geraldo W.; CRUZ, Héctor G. Bartolomei. La Organización Internacional del Trabajo - El Sistema Normativo Internacional - Los Instrumentos sobre Derechos Humanos Fundamentales. Buenos Aires: Editorial Astrea de Alfredo y Ricardo Depalma, 1990.

RezeK, José Francisco. Curso de Direito Internacional Público. Vol. I. São Paulo: Atlas, 2002.

ReZeK, José Francisco. Direito Internacional Público- Curso Elementar. $6^{a}$ ed. São Paulo: Saraiva, 1996.

REZEK, José Francisco. Direito dos Tratados. Rio de Janeiro: Forense, 1984.

SARLET, Ingo Wolfgang. A Eficácia dos Direitos Fundamentais. $8^{\mathrm{a}}$ ed. Porto Alegre: Livraria do Advogado, 2007.

SCHIER, Paulo Ricardo. Hierarquia Constitucional dos Tratados Internacionais de Direitos Humanos e EC 45 - Tese em Favor da Incidência do Tempus Regit Actum. Disponível em 
www.conpedi.org/manaus/arquivos/Anais/Paulo\%20Ricardo\%20Schier.pdf. Acesso em $14 / 10 / 2008$.

Silva, José Afonso. Curso de Direito Constitucional Positivo. $28^{\mathrm{a}}$ ed. São Paulo: Malheiros, 2006.

Silva, Walküre Lopes Ribeiro. O.I.T. e Direito do Trabalho no Brasil. Dissertação (mestrado). Faculdade de Direito da Universidade de São Paulo. São Paulo, 1982.

SoARes, Guido Fernando Silva. Curso de Direito Internacional Público. Vol. 1. São Paulo: Atlas, 2002.

Souto MaIOR, Jorge Luiz. O Direito do Trabalho como Instrumento de Justiça Social. São Paulo: LTr, 2000.

Souto MAIOR, Jorge Luiz; CORREIA, Marcus Orione Gonçalves. O que é Direito Social? in CorreIA, Marcus Orione Gonçalves (org.). Curso de Direito do Trabalho - Teoria Geral do Direito do Trabalho. Vol. I. São Paulo: LTr, 2007.

SÜSSEKIND, Arnaldo. Convenções da OIT. $2^{\mathrm{a}}$ ed. São Paulo: LTr, 1998.

SüSSEKIND, Arnaldo. Direito Internacional do Trabalho. $3^{\text {a }}$ ed. São Paulo: Saraiva, 2000.

Uriarte, Oscar Ermida. A Aplicação Judicial das Normas Constitucionais e Internacionais sobre Direitos Humanos Trabalhistas, in Fórum Internacional sobre Direitos Humanos e Direitos Sociais, organização e realização Tribunal Superior do Trabalho. São Paulo: LTr, 2004.

VAlladẽo, Haroldo. Direito Internacional Privado. Vol. I. 5a ed. Rio de Janeiro: Freitas Bastos, 1980.

VAlticos, Nicolas. Derecho Internacional del Trabajo. Trad. Esp. de Maria Jose Triviño. Madrid: Editorial Tecnos, 1977. 
WeIS, Carlos. Direitos Humanos Contemporâneos. São Paulo: Malheiros, 1999. 